UNIVERSIDADE DE SÃO PAULO

FACULDADE DE ECONOMIA, ADMINISTRAÇÃO E CONTABILIDADE DEPARTAMENTO DE ECONOMIA PROGRAMA DE PÓS-GRADUAÇÃO EM ECONOMIA

POLÍTICA FISCAL, PREVISÕES ORÇAMENTÁRIAS E OS DETERMINANTES DOS DESVIOS DE EXECUÇÃO NO BRASIL

Elaine Cristina de Piza

Orientadora: Prof. ${ }^{a}$ Dr. ${ }^{a}$ Fabiana Fontes Rocha

SÃO PAULO 
Prof. Dr. Marco Antonio Zago Reitor da Universidade de São Paulo

Prof. Dr. Adalberto Américo Fischmann Diretor da Faculdade de Economia, Administração e Contabilidade

Prof. Dr. Hélio Nogueira da Cruz Chefe do Departamento de Economia

Prof. Dr. Márcio Issao Nakane Coordenador do Programa de Pós-Graduação em Economia 
ELAINE CRISTINA DE PIZA

\section{POLÍTICA FISCAL, PREVISÕES ORÇAMENTÁRIAS E OS DETERMINANTES DOS DESVIOS DE EXECUÇÃO NO BRASIL}

Tese apresentada ao Departamento de Economia da Faculdade de Economia, Administração e Contabilidade da Universidade de São Paulo como requisito para a obtenção do título de Doutora em Ciências.

Orientadora: Prof. ${ }^{a}$ Dr. ${ }^{a}$ Fabiana Fontes Rocha

\section{Versão Corrigida}

(versão original disponível na Biblioteca da Faculdade de Economia, Administração e Contabilidade)

SÃO PAULO 
FICHA CATALOGRÁFICA

Elaborada pela Seção de Processamento Técnico do SBD/FEA/USP

Piza, Elaine Cristina de.

Politica fiscal, previsōes orçamentárias e os determinantes dos desvios de execução no Brasil / Elaine Cristina de Piza. -- São Paulo, 2016.

190 p.

Tese (Doutorado) - Universidade de Sāo Paulo, 2016.

Orientador: Fabiana Fontes Rocha.

1. Politica fiscal. 2. Previsōes orçamentárias. 3. Desvio de execuçāo. 4. Dados em tempo real. I. Universidade de Sāo Paulo. Faculdade de Economia, Administraçāo e Contabilidade. II. Titulo.

CDD -336.3 
Para Arthur Cattaneo Zavadski, Nerio

Balse de Piza e Inez A. F. de Piza, com

amor. 


\section{AGRADECIMENTOS}

Diversas pessoas me ajudaram a chegar até aqui. A principal delas, meu marido Arthur, que sempre esteve ao meu lado, incentivando-me, acreditando em mim, e com todo seu amor e dedicação, criou o ambiente favorável para que esse sonho se tornasse possível. Agradeço também imensamente aos meus pais por todo apoio, por todo amor e por toda a compreensão pelas inúmeras vezes que não estive presente ao lado de vocês. Aos demais familiares e amigos queridos de longa data que compreenderam minhas incontáveis ausências.

Agradeço imensamente à minha orientadora, professora Fabiana, por ter aceito me assumir como orientanda no meio do caminho. Obrigada por toda a compreensão, disponibilidade e por me ajudar na tarefa de me tornar uma pesquisadora.

Ao professor Albert Fishlow por toda a competência, profissionalismo e por todo o interesse e dedicação com o qual me recebeu na Columbia University. Seu conhecimento é fascinante. Obrigada por ser tão disponível aos alunos e, principalmente, obrigada pela orientação em relação a tese. Sua contribuição foi essencial. Agradeço também à Columbia University e aos professores e funcionários do ILAS por toda estrutura e profissionalismo dispensados aos Visiting Scholars.

Aos colegas de curso com quem compartilhei momentos de sufoco, mas também de alívio: Júlia, Guilherme, Carlândia. Sou grata a Deus por ter colocado vocês em minha vida. Com cada um de vocês, pessoas de personalidades tão distintas, aprendi coisas que me ajudaram a me tornar uma pessoa melhor.

Aos professores da FEA, em especial aqueles que sempre estiveram disponíveis para nos ajudar: professores Gilberto, Postali, Colistete, professora Vera. Agradeço também ao Pinho e a Leka, o suporte de vocês foi essencial.

Agradeço à Universidade Estadual de Maringá e ao Departamento de Economia que tornaram meu afastamento possível para me dedicar ao doutorado. Agradeço também ao CNPq pelo apoio financeiro e à Capes por ter tornado possível meu estágio na Universidade de Columbia. 


\section{RESUMO}

O objetivo desta tese é analisar os determinantes políticos e econômicos dos desvios de execução orçamentária no Brasil, no período de 2002 a 2015. Desvios de execução são definidos como a diferença entre o valor observado da variável e o valor previsto no orçamento. A partir do uso de dados em tempo real, isto é, dados disponíveis aos formuladores de política no momento em que as decisões de política fiscal são tomadas, busca-se compreender os desvios de execução da política físcal à luz de alguns fatores atuantes na fase de planejamento e execução da política, confrontando a intencionalidade declarada pelo executor da política no planejamento orçamentário com os resultados finais obtidos. Para contornar a ausência de uma base de dados em tempo real organizada para a economia brasileira, a base utilizada foi construída a partir dos documentos oficiais gerados ao longo das fases do processo orçamentário. A construção dessa base, no entanto, limitou-se em função da insuficiência de dados em tempo real de acesso público. Para atingir o objetivo proposto, os desvios de execução fiscal foram inicialmente avaliados a partir da análise dos eventos que condicionaram o planejamento e a execução do orçamento. À esta análise somouse uma análise empírica, na qual buscou-se identificar os determinantes da fase de planejamento, a partir da análise dos fatores que influenciam na previsão de arrecadação, e os condicionantes da fase de execução orçamentária, a partir da identificação dos fatores que contribuem para os desvios de execução. Os resultados indicam que a previsão fiscal distanciou-se mais significativamente dos valores realizados a partir do ano de 2012 e que os desvios nas previsões dos fatores macroeconômicos, sobretudo na previsão de crescimento do PIB ajudam a explicar esse distanciamento. Verificou-se também um otimismo persistente nas projeções de crescimento do PIB utilizadas para a elaboração do orçamento. Adicionalmente, verificou-se que a adoção de subterfúgios contábeis adotados pelo Governo para atingir artificialmente as metas de superávit primário resultam em uma execução orçamentária desvinculada do orçamento planejado, dificultando a análise dos desvios de execução e transformando o processo de planejamento orçamentário em mera exigência legal, sem aplicação prática.

Palavras-chave: Política Fiscal; Dados em Tempo Real; Previsões Orçamentárias; Desvios de Execução. 


\begin{abstract}
This thesis aims to analyze the politic and economic determinants of the budget execution deviation in Brazil, from 2002 to 2015. Execution deviation is defined as the difference between the observed value of the variable and the forecast budget value. From the use of real-time data, i.e., data available to policy makers at the time the fiscal policy decisions are taken, we seek to understand the execution deviations from fiscal policy in the light of some active factors during the planning phase and policy execution, confronting the intention declared by the policy maker in the budget planning with the final results. To work around the lack of a real-time dataset organized for the Brazilian economy, the dataset used was built from the official documents generated throughout the phases of the budget process. The construction of this dataset, however, was limited due to insufficient data in real-time public access. To achieve this goal, the fiscal execution deviations were initially evaluated from the analysis of the events that conditioned the planning and execution of the budget. To this analysis we added up an empirical analysis, in which we attempted to identify the determinants of the planning phase from the analysis of the factors that influence in the revenue forecast and the conditioners of the budget execution phase from the identification of factors contributing to the execution deviations. The results indicate that the realized values drifted away significantly more from the fiscal forecast from the year 2008 and that the deviations in the forecasts of macroeconomic factors, particularly in the GDP growth forecast, help to explain this gap.
\end{abstract}

Keywords: Fiscal Policy; Real-time Data; Budget forecasts; Execution Deviations. 


\section{SUMÁRIO}



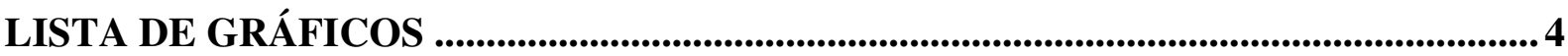

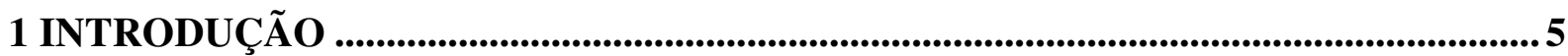

2 REVISÃO LITERATURA …............................................................................. 10

2.1 Introdução ……………………………………………………………………... 10

2.2 Política Fiscal com Dados em Tempo Real ………………………………………..... 10

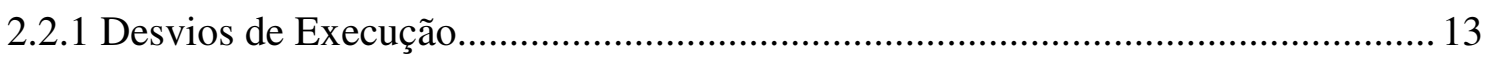

2.3 Dados em Tempo Real na Literatura Econômica de Política Fiscal................................. 15

2.3.1 Propriedades Estatísticas das Revisões dos Dados ................................................ 16

2.3.2 Reação da Política Fiscal com Dados em Tempo-Real .......................................... 19

2.4 Determinantes Econômicos, Políticos e Institucionais dos Desvios de Execução .........21

2.4.1 Determinantes Econômicos ……………………………………………………..... 22

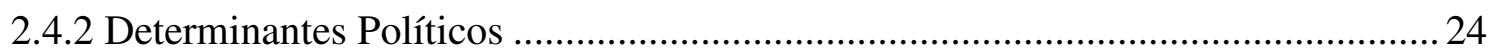

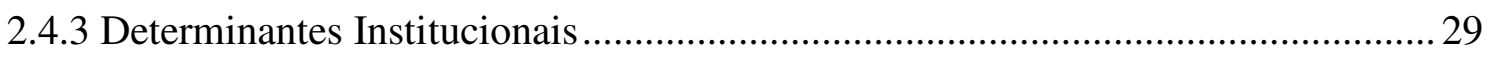

2.5 Estudos Empíricos com Dados em Tempo Real...…………………………………..... 33

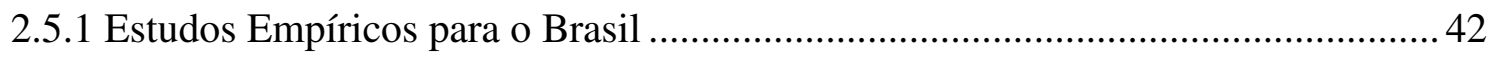

3 PROCESSO ORÇAMENTÁRIO NO BRASIL .......................................................44

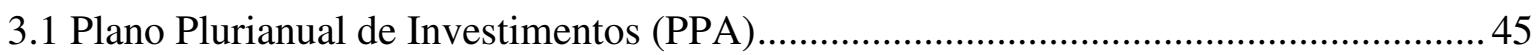

3.2 Lei de Diretrizes Orçamentárias (LDO) ....................................................................... 46

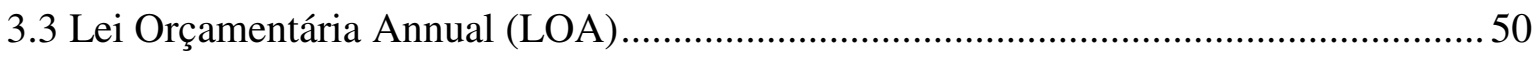

3.4 Breves Notas sobre a Previsão da Receita Orçamentária ................................................56

3.5 Implementação e Controle do Orçamento ………………………………………….....59

4 OS DESVIOS DE EXECUÇÃO ORÇAMENTÁRIOS DE 2002 A 2015: VISÃO

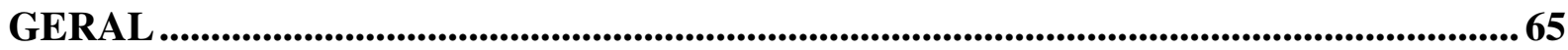

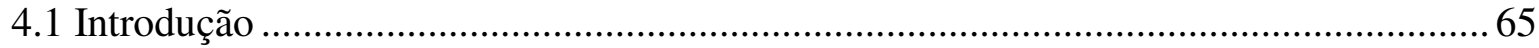

4.2 Construção da Base de Dados em Tempo Real ............................................................. 65

4.3 Os desvios de execução orçamentários....................................................................... 72

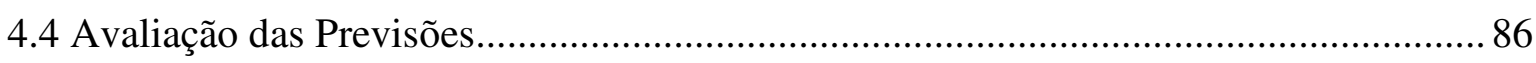

5 CONDICIONANTES DA POLÍTICA FISCAL: O PLANEJAMENTO E A EXECUÇÃO ORÇAMENTÁRIA NO PERÍODO DE 2002 A $2015 \quad$.............................92

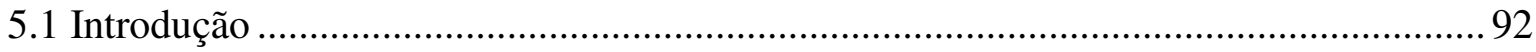


5.2 Choques Externos e Eleição: o conturbado ano de 2002 92

5.3 Determinantes dos Desvios de Execução Orçamentários no Governo Lula: 2003 a 2010 105

5.3.1 O período de 2004 a 2010 . 117

5.4 O Período 2011 a 2015 - O Governo Dilma e a Elevação dos Desvios de Execução 129 6 DETERMINANTES POLÍTICOS E ECONÔMICOS DOS DESVIOS DE EXECUÇÃO DA POLÍTICA FISCAL NO BRASIL ......................................................... 137

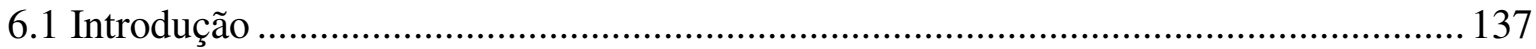

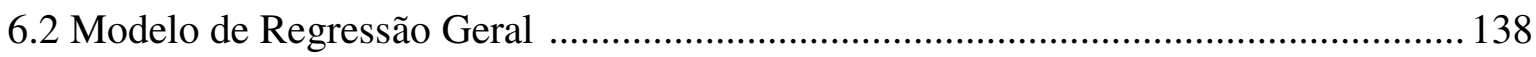

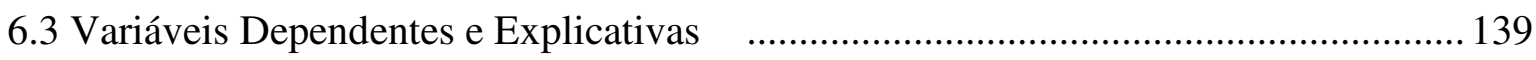

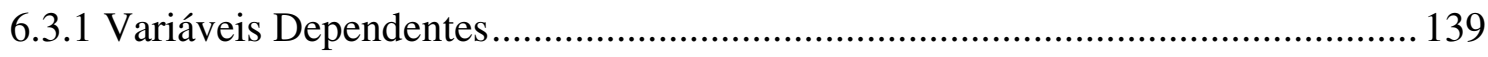

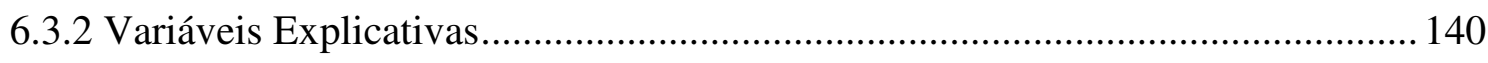

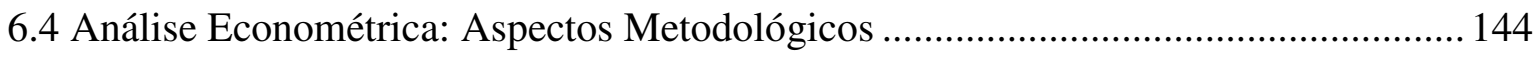

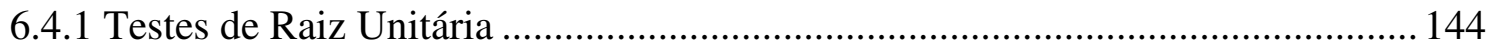

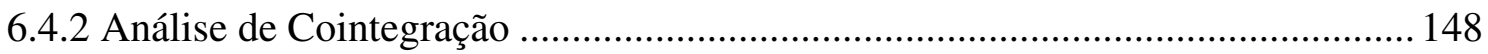

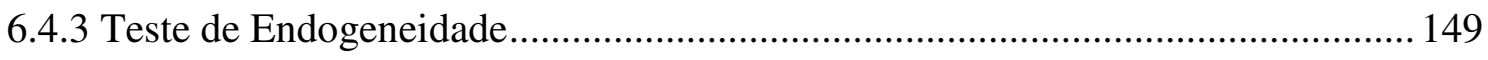

6.5 Análise dos Determinantes do Desvio de Execução .................................................. 151

6.5.1 Resultados das Regressões: Equação do Desvio de Execução ............................. 154

6.5.2 Análise dos Resultados: Determinantes da Fase de Planejamento ...................... 163

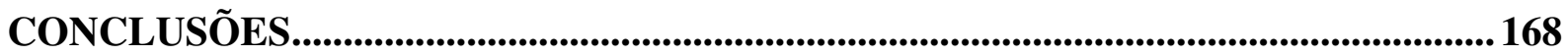

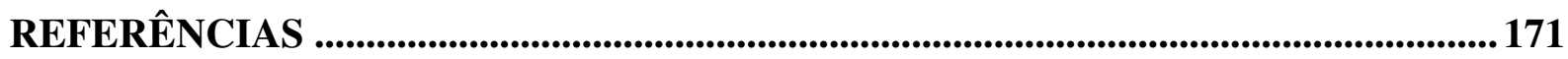

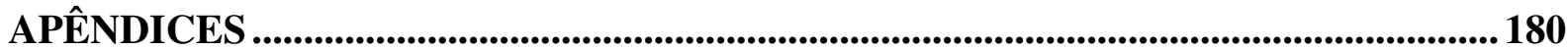




\section{LISTA DE TABELAS}

Tabela 1 - Sumário das principais variáveis utilizadas na literatura..................................... 42

Tabela 2 - Alterações na PLOA e valores realizados - R \$ bilhões......................................... 85

Tabela 3 - Avaliação Desvios de execução: Receita, Despesa e IPCA …................................ 87

Tabela 4 - Avaliação Desvios de execução: Selic, Taxa de Câmbio e IGP-DI ....................... 89

Tabela 5 - Avaliação Desvios de execução: PIB (\% crescimento real) .................................. 89

Tabela 6 - Desvios de execução: Comparações Planejamento Orçamentário .......................... 90

Tabela 7 - Contingenciamento das Despesas Discricionárias do Poder Executivo ................ 105

Tabela 8 - Desvio de Previsão do Crescimento Real do PIB - 2003 a 2010 ......................... 106

Tabela 9 - Variáveis Macroeconômicas Projetadas - 2003 ................................................... 107

Tabela 10 - Comparativo Receita e Despesa Prevista LDO, PLOA, LOA e Decretos de

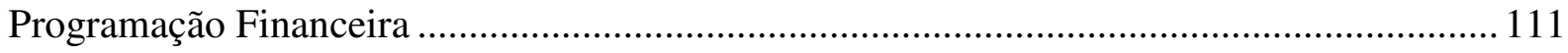

Tabela 11 - Evolução Arrecadação Receitas Selecionadas - R\$ bilhões ............................. 118

Tabela 12- Evolução dos Parâmetros Macroeconômicos Previstos - 2009 ........................... 123

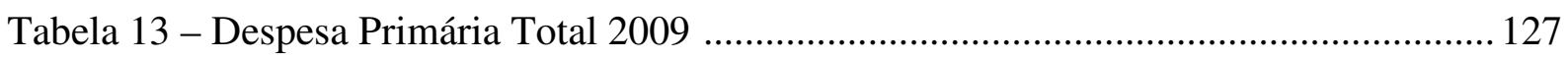

Tabela 14 — Previsões contidas na LOA versus valores realizados.................................... 134

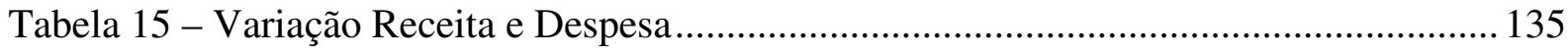

Tabela 16 - Resultado Primário Governo Central - Governo Dilma.................................... 135

Tabela 17 - Restos a Pagar Inscritos no Ano de Referência .................................................. 136

Tabela 18 - Teste Dickey-Fuller Aumentado (ADF) e DF-GLS ......................................... 146

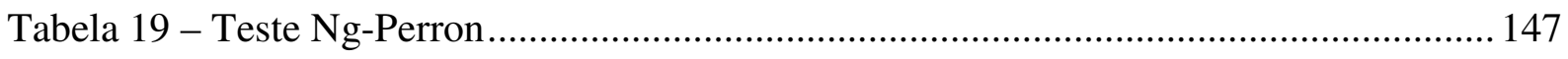

Tabela 20 - Teste de Cointegração de Johansen ................................................................ 148

Tabela 21 - Teste de Durbin-Wu-Hausman - Equação do Desvio de Execução..................... 150

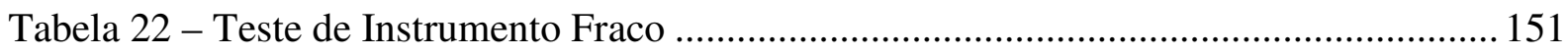

Tabela 23 - Determinantes dos Desvios de Execução da Receita .......................................... 156

Tabela 24 - Determinantes dos Desvios de Execução da Receita ........................................ 160

Tabela 25 - Teste de Durbin-Wu-Hausman - Equação do Receita Prevista .......................... 163

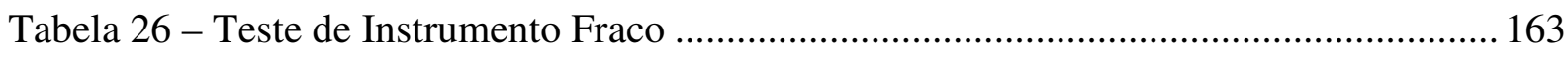

Tabela 23 - Determinantes da Receita Prevista .................................................................. 166 


\section{LISTA DE GRÁFICOS}

Ilustração 1 - Documentos Oficiais do Processo Orçamentário Utilizadas na Construção da Base de Dados 66

Gráfico 1 - Receita Primária Total do Governo Central, valores previstos e realizados - R\$ bilhões 73

Gráfico 2 - Desvio de Execução da Receita Primária Total do Governo Central (LOA)

- R $\$$ bilhões 74

Gráfico 3 - Receita Primária Total prevista na LDO e realizada - R \$ bilhões 75

Gráfico 4 - Desvio Execução da Receita Primária Total em relação a LDO .75

Gráfico 5 - Desvio Execução da Receita Primária Total (LDO, PLOA, LOA, Programação 76

Gráfico 6 - Despesa Primária Total do Governo Central, valores previstos e realizados $\mathrm{R} \$$ bilhões

Gráfico 7 - Desvio Execução da Despesa Primária Total (PLOA, LOA, Programação) $\mathrm{R}$ \$ bilhões .78

Gráfico 8 - Taxa de Crescimento Real do PIB, valores previstos e realizados .79

Gráfico 9 - Taxa de Crescimento Real do PIB, valores previstos e realizados. 80

Gráfico 10 - Taxa de Inflação IGP-DI, valores previstos e realizados 81 
Nos últimos 14 anos, o planejamento fiscal no Brasil mostrou-se extremamente otimista, subestimando, ou não antecipando, os eventos que impactaram negativamente a economia. Como resultado, os desvios entre os resultados fiscais observados e o planejamento contido no orçamento tornaram-se crescentes, sobretudo no período posterior a 2009.

A expectativa de crescimento real do PIB é o melhor exemplo do otimismo presente nas projeções orçamentárias. De 2002 a 2015, as taxas esperadas de crescimento real da atividade econômica que embasaram as previsões de arrecadação e de despesas foram superestimadas, apenas em 4 destes anos é que a taxa de crescimento efetiva superou a taxa prevista. Em outras palavras, os resultados fiscais foram estimados com base em projeções de crescimento otimistas que não se verificaram em todos os momentos.

Desvios entre os resultados fiscais observados e os planos do governo são chamados de desvios de execução e são, principalmente, influenciados pela incerteza que envolve o processo de previsão e por choques inesperados. As previsões fiscais e seus respectivos desvios podem ser explicados por fatores econômicos, políticos e institucionais. Os fatores econômicos dizem respeito às oscilações macroeconômicas que afetam tanto a arrecadação de receitas quanto a realização das despesas públicas. Mais precisamente, os determinantes econômicos referem-se à magnitude na qual os erros nas projeções orçamentárias são afetados pelos erros na previsão de variáveis econômicas chaves como a taxa de crescimento esperada. Os determinantes políticos referem-se ao grau no qual a fragmentação política, o calendário eleitoral e a ideologia partidária impactam as previsões e os resultados fiscais. As hipóteses subjacentes são que os governos podem manipular as previsões orçamentárias para atender interesses políticos e que a orientação política e o arranjo institucional do governo também influenciam a qualidade das previsões. Os determinantes institucionais referem-se às estruturas jurídicas e políticas que norteiam a elaboração, aprovação e execução do orçamento, além de definir as regras para o equilíbrio fiscal.

Os desvios de execução são indicativos de não aderência da execução orçamentária aos objetivos da política fiscal. Esses desvios entre planos ex-ante e resultados ex-post podem ocorrer devido a fatores externos e internos, tais como: erros na expectativa de crescimento do 
PIB; superestimação/subestimação das despesas e/ou das receitas esperadas, oportunismo eleitoral, entre outros. Os desvios de previsão podem ser gerados tanto por miopia por parte do governo, que não consegue avaliar corretamente o cenário macroeconômico em que se encontra, em razão, por exemplo, de insuficiência técnica ou instabilidade no ambiente econômico, ou por uma ação intencional, por exemplo, ao prever um cenário excessivamente otimista que lhe permita autorizar um volume maior de despesas em anos eleitorais.

Para investigar os determinantes dos desvios de execução é necessário avaliar a execução da política fiscal em seus dois estágios: o estágio do planejamento, fase que contempla a preparação do orçamento com as estimativas dos dispêndios e das fontes de financiamento previstos, e o estágio da implementação, em que a plano fiscal é posto em prática com a realização da arrecadação e dos dispêndios planejados (BEETSMA e GIULIODORI, 2010). Ambos os estágios determinam os resultados da política e ocorrem em momentos distintos no tempo, sujeitos às mudanças nas condições macroeconômicas e às atualizações no conjunto de informações disponíveis aos formuladores de política. A avaliação completa da política fiscal deve considerar as duas fases conjuntamente, uma vez que a implementação da política pode diferir dos planos anunciados, isto é, pode haver diferenças significativas entre as medidas fiscais discricionárias planejadas e as medidas observadas ex-post, de forma que o resultado da política fiscal tende a divergir do esperado.

A previsão das receitas e despesas é parte fundamental do processo orçamentário e desempenha papel essencial nos resultados alcançados. O protagonismo exercido pela previsão é confirmado pela Lei de Responsabilidade Fiscal (Art. $11^{\circ}$ ) ao afirmar que a previsão e efetiva arrecadação de todos os tributos são requisitos essenciais da responsabilidade na gestão fiscal. Contudo, como notam Afonso e Carvalho (2013), fazer previsões precisas sobre a arrecadação não é uma tarefa trivial. Ao contrário, requer um amplo conjunto de variáveis, igualmente difíceis de serem previstas com precisão, entre as quais se incluem a taxa de crescimento do PIB, a taxa de inflação, a taxa de câmbio e a taxa de juros, além do comportamento dos indivíduos diante de incertezas, entre outras. Somadas às dificuldades envolvidas nas estimativas, há ainda o componente politico que exerce importante impacto sobre o planejamento fiscal e sua execução. Nesse aspecto, as estimativas orçamentárias podem ser manejadas com a intenção de obter benefícios políticos, como a reeleição de um governo ou a manutenção de um partido no poder. 
Apesar da importância em compreender a política fiscal em suas várias etapas e da possibilidade que os resultados da política sejam contrários à política intencionada, a literatura dedicou pouca atenção à análise empírica do estágio de planejamento, focando-se na análise dos resultados ex-post. A fim de corrigir essa carência, diversos pesquisadores procuram interpretar o comportamento cíclico da política fiscal a partir do uso de dados em tempo-real, ou seja, o conjunto de informações que estavam disponíveis ao formulador de política no momento em que as decisões de política foram tomadas. No caso particular da política fiscal, os dados em tempo real são as primeiras estimativas originais (não revistas) das variáveis macroeconômicas, ou as previsões que os formuladores de políticas possuem no momento em que os planos orçamentários são realizados. A aplicação de dados em tempo real ocorreu inicialmente na análise da política monetária com as contribuições de Orphanides (1997), porém, na análise da política fiscal, as pesquisas que utilizam dados ex-ante em tempo real são relativamente novas e, em especial, restritas às economias da OCDE.

É nesse aspecto da política fiscal que a presente pesquisa se insere. O objetivo principal desta tese é investigar o planejamento e a execução da política fiscal brasileira no período de 2002 a 2015 com ênfase na mensuração dos desvios de execução orçamentários e na identificação dos determinantes desses erros. A partir do uso de dados conhecidos na literatura como dados em tempo real, isto é, dados disponíveis aos formuladores de políticas no momento em que as decisões de política fiscal são tomadas, busca-se compreender os resultados da política fiscal à luz dos mecanismos atuantes na fase de planejamento da política, confrontando a intencionalidade declarada do gestor fiscal com os resultados obtidos.

Para atingir o objetivo proposto, esta pesquisa será apresentada em 5 capítulos além desta introdução. No capítulo 2, a literatura concernente a esta tese e a definição de desvio de execução será apresentada. Na sequência, o capítulo 3 complementará a fundamentação teórica na medida em que apresentará o processo orçamentário no Brasil e a estrutura institucional atrelada às fases de previsão e de execução orçamentária. No quarto capítulo apresentaremos uma visão geral dos desvios de execução observados no período de 2002 a 2015 e a análise das medidas de erro dos desvios: Erro Médio, Erro Quadrado Médio e Raiz do Erro Quadrado Médio. Adicionalmente, descreveremos a construção da base de dados utilizada na pesquisa. No quinto capítulo faremos uma análise descritiva dos eventos políticos e econômicos ocorridos na economia brasileira durante o período sob investigação, com o objetivo de identificar os condicionantes do planejamento e da execução orçamentária e o 
resposta do Governo a estes eventos. No sexto capítulo, apresentaremos os resultados da análise econométrica realizada com o objetivo de identificar os determinantes dos desvios e execução. Por fim, apresentaremos as considerações e conclusões a respeito dos resultados encontrados. 
$\mathrm{O}$ assunto concernente a essa tese relaciona-se com diferentes vertentes da literatura de política fiscal. Em primeiro lugar, relaciona-se com a literatura que investiga os resultados fiscais e o comportamento das autoridades fiscais a partir de dados em tempo real. Em segundo lugar, esta pesquisa relaciona-se com a literatura que aborda a precisão da previsão econômica e o papel das instituições fiscais na produção dessas previsões. Por fim, esta tese está inserida no conjunto das pesquisas que exploram o papel dos determinantes econômicos, políticos e institucionais da política fiscal a partir de dados em tempo real. Apesar das vertentes citadas se relacionarem entre si serão apresentadas em tópicos separados ao longo desse capítulo com o objetivo de situar essa pesquisa na referida literatura. Dessa forma, a seção seguinte explicará o que são dados em tempo real, na sequência será definido o conceito de desvios de execução. Posteriormente, será apresentada a literatura sobre dados em tempo real na política fiscal e, por fim, será apresentada a literatura sobre os determinantes dos desvios de execução.

\section{2}

\section{Política Fiscal com Dados em Tempo Real}

Dados em tempo real são os dados que estavam disponíveis aos formuladores de política no momento em que eles tomaram determinada decisão de política. No caso particular da política fiscal, os dados em tempo real são as primeiras estimativas originais (não revistas) das variáveis macroeconômicas, ou as previsões que os formuladores de políticas possuem no momento em que os planos orçamentários são realizados. O exemplo a seguir ajudará a entender melhor o conceito.

Em janeiro de 2002, a ata da $67^{\mathrm{a}}$ reunião do Conselho de Política Monetária (COPOM) trazia a seguinte avaliação da situação econômica:

“(...) os indicadores econômicos revelam gradual e consistente superação das adversidades enfrentadas em 2001. Essa percepção vem se refletindo no nível de confiança dos consumidores, que se eleva desde outubro passado. O nível de estoques no último trimestre de 2001 declinou em relação ao trimestre anterior, a inadimplência em dezembro atingiu nível mais baixo nos últimos cinco anos e a demanda vem sinalizando recuperação gradativa. Estes 
fatos reforçam a expectativa de recuperação do nível de atividade, o que não deve inibir as perspectivas positivas para a balança comercial em 2002 na medida em que melhoram as expectativas de retomada do crescimento no exterior (...). Como resultado desta melhora no cenário econômico, assim como do esgotamento dos efeitos primários dos choques ocorridos em 2001 e da menor pressão dos preços administrados por contrato, as perspectivas para as taxas de inflação neste e no próximo ano são de queda em direção à trajetória das suas metas. Essa percepção é compartilhada pelos agentes econômicos, como indicam as expectativas para a inflação de 2002 e 2003 na pesquisa coletada pelo Grupo de Comunicação Institucional (GCI) do Banco Central" (COPOM, 2002).

A transcrição do trecho da ata do COPOM mostra que o Banco Central estava apostando em um cenário bastante favorável para o ano de 2002. As expectativas eram de recuperação do crescimento econômico e queda nas taxa de inflação em direção às metas. Diante do quadro favorável, o COPOM decidiu, por unanimidade, manter a taxa de juros Selic inalterada em $19 \%$ ao ano. As expectativas favoráveis em relação à inflação mantiveram-se até o mês de setembro de 2002, quando a taxa Selic foi reduzida para $18 \%$ ao ano. As mesmas expectativas favoráveis embasaram a Lei Orçamentária Anual aprovada para 2002.

Porém, se olharmos somente os dados finais de 2002, veremos que a taxa de inflação medida pelo Índice de Preços ao Consumidor Amplo (IPCA) fechou o ano em 12,53\%, bem acima do teto da meta que era 5,5\% ao ano e que o ano terminou com a taxa de juros Selic em 25\%, além de o país ter recorrido a um novo empréstimo junto ao Fundo Monetário Internacional. Uma busca nas estatísticas oficiais hoje mostrará que a taxa de crescimento real do PIB em 2002 foi de 3,08\%. No entanto, em dezembro daquele ano, a prévia realizada pelo Banco Central indicava que o crescimento real da economia em 2002 era de 1,6\%.

Portanto, como explicado por Croushore (2011), se analisarmos as decisões de política econômica adotadas ao longo de um determinado período usando os dados disponíveis hoje, provavelmente avaliaremos incorretamente as políticas adotadas. Ao contrário, ao olharmos para os dados que estavam disponíveis aos formuladores de políticas no momento em que tais políticas foram executadas, poderemos ter um retrato mais fiel das razões que as motivaram e, dessa forma, estaremos realizando uma análise de dados em tempo-real.

A literatura de análise em tempo real teve origem na década de 1950, mas foi somente na década de 1990 que esta literatura ganhou consistência, com o desenvolvimento de um grande conjunto de dados em tempo real para a economia americana desenvolvido por Dean 
Croushore e Tom Stark $^{1}$ (CUSINATO et alli, 2010a). A aplicação desses dados ocorreu inicialmente na análise da política monetária com as contribuições de Orphanides (1997). Na análise da política fiscal, o uso de dados ex-ante em tempo-real é relativamente recente e, em sua maioria, dirigida aos países da União Europeia e OCDE, em função da insuficiente disponibilidade de dados fiscais em tempo real para períodos mais longos e para outras economias.

Cimadomo (2011) relata a existência de 5 base de dados $^{2}$ que incluem variáveis fiscais em tempo real, sendo 2 delas com dados dos Estados Unidos (Base de dados do Federal Reserve em Philadelphia e a base de dados ALFRED do Federal Reserve de St. Louis), 2 bases de dados para os países da Zona do Euro (Euro Area Business Cycle Network - EABCN e a base do European Central Bank - ECB), 1 base de dados para a Inglaterra fornecida pelo Bank of England e, por fim, uma base de dados para os maiores países da Organização para a Cooperação e Desenvolvimento Econômico (OCDE) e alguns países fora da OCDE entre os quais. Esta última base de dados da OCDE inclui dados do Brasil, mas apenas revisões do PIB com vintages ${ }^{3}$ a partir de 2014. Dentre estas bases de dados, as mais completas são aquelas referentes aos Estados Unidos cujos primeiros vintages sobre despesas públicas são de 1965 e os primeiros para a receita são de 1974. As variáveis fiscais para os países da OCDE contem vintages a partir de 2001.

O uso de dados em tempo real é preferido por pesquisadores interessados em avaliar a política econômica passada a partir das informações que estavam disponíveis ao formulador de política fiscal no momento em que as decisões sobre o orçamento corrente e futuro foram tomadas. A análise baseada nestes dados reflete mais claramente, o tanto quanto é possível, o comportamento e a intenção do formulador de política. Como exposto por Beetsma et alli (2013), este tipo de análise contrasta com a análise econométrica usual, na qual os pesquisadores utilizam uma base de dados com as últimas atualizações disponíveis dos dados para explicar decisões passadas, ou para avaliar a performance das previsões a partir de uma

\footnotetext{
${ }^{1}$ A base de dados é conhecida como Real-Time Dataset for Macroeconomists e foi desenvolvida no Federal Reserve Bank of Philadelphia. Mais detalhes a respeito podem ser encontrados em Croushore e Stark (2000, 2001).

${ }^{2}$ Croushore (2011) relata a existência de bases de dados em tempo real para o PIB no Japão e na Nova Zelândia. ${ }^{3}$ Vintage: conjunto de informações disponíveis de uma variável em um período particular. Por exemplo, pode haver $n$ vintages referentes aos dados relativos ao primeiro bimestre de 2002, um vintage de 2001 com previsões para o primeiro bimestre de 2002, outro vintage de 2002 com previsões para 2002 e um vintage de 2003 com estimativas dos valores realizados em 2002. A coleção de vintages forma o conjunto de dados em tempo real (CROUSHORE; STARK, 1999).
} 
base de dados mais atualizada e com maior acurácia do que o conjunto de informações disponíveis quando as previsões foram realizadas.

\subsubsection{Desvios de Execução}

Após explicar o que são os dados em tempo-real, nesse ponto é necessário explicar a definição de "desvios de execução" que será utilizada ao longo de toda a tese.

A diferença entre o valor observado da variável e o valor previsto no orçamento é mais comumente conhecida na literatura como erro de previsão. Seguindo a representação utilizada por Pina e Venes (2011), temos:

$e_{t}=R_{t}-F_{t-1}$

Sendo:

$e_{t}=$ erro de previsão no período $\mathrm{t}$

$R_{t}=$ resultado observado em $\mathrm{t}$

$F_{t-1}=$ resultado previsto no período t-1

Martins (2012) separa a literatura sobre desvios orçamentários em dois grupos de acordo com a denominação atribuída ao termo $e_{t}$ na equação 1 . Enquanto parte da literatura denomina a diferença entre planos e resultados como erro de previsão (STRAUCH et alli, 2004; BRUCK e STEPHAN, 2006; ANNETT, 2006; AFONSO e CARVALHO, 2013), outros autores chamam de erro de implementação (BEETSMA e GIULIODORI, 2010, BEETSMA et alli, 2009; PINA 2009). Os autores que chamam de erro de implementação estão interessados em compreender os planos fiscais e a execução desses planos, ou seja, tanto a fase de planejamento quanto a fase de execução da política fiscal. Moulin e Wierts (2006) contribuem para o entendimento da diferença entre erros de previsão e erros de implementação. Os autores tentam verificar em que medida os desvios entre resultado final e previsões são devidos a não implementação dos planos fiscais e em que medida esses desvios devem-se aos erros de previsão do crescimento econômico.

Lledó e Poplawski-Ribeiro (2013) chamam as diferenças entre as mudanças nos planos e nos resultados fiscais de hiato de implementação. Os autores, que aplicam dados em tempo-real à 
análise da implementação da política fiscal nos países da África Subsaariana, explicam que preferem adotar um termo mais neutro porque as diferenças entre planos e resultados podem não necessariamente refletir erros ou riscos elevados, mas sim revisões decorrentes de choques externos imprevistos aos quais os países menos desenvolvidos estão vulneráveis.

Von Hagen (2010) define o termo $e_{t}$ na equação (1) de erro de projeção. O autor chama a atenção para o fato de que utilizar o termo "erro" é um abuso de linguagem, porque os desvios entre os valores verdadeiros e os valores projetados não são necessariamente um "erro" no sentido de serem inteiramente devidos a falta de informação. $\mathrm{O}$ autor afirma que o erro de projeção para as variáveis fiscais consiste de dois elementos. Um é a mudança endógena na variável projetada em função de mudanças não previstas no ambiente econômico. O outro elemento é a mudança na variável em função de políticas discricionárias. Identificar os dois elementos requer conhecer como a variável fiscal sob análise reage a mudanças não previstas, como por exemplo, como reage aos erros de projeção do PIB.

Já Cebotari et alli (2008) referem-se a $e_{t}$ como risco fiscal, haja vista que os resultados fiscais podem diferir substancialmente das projeções contidas no orçamento em função de choques inesperados tais como os desvios entre o crescimento econômico e as expectativas, choques nos termos de troca, desastres naturais, dentre outros choques que requerem ações não antecipadas pelos governos.

Nesta tese adotaremos o termo "desvio de execução". Seguindo o raciocínio de Lledó e Poplawski-Ribeiro (2013), consideramos que a diferença entre valores previstos e realizados não necessariamente representa um erro cometido na gestão orçamentária, podendo ser resultado de choques inesperados. Além disso, na medida em que as previsões contidas no orçamento podem refletir objetivos políticos, ao invés de refletir o conjunto de informações disponível ao formulador de política no momento da elaboração do orçamento, não faz sentido chamar de erro de previsão a diferença entre o valor realizado e o valor previsto. Nesta mesma linha de interpretação, Cepparulo et alli (2011) também consideram que o plano contido no orçamento está sujeito a mudanças não apenas em função de eventos inesperados ou choques econômicos, mas também em função de mudanças nas prioridades da agenda política. Assim sendo, adotaremos o termo desvio de execução para nos referirmos ao termo $e_{t}$ na Equação 1. 
Desvios de execução negativos ocorrem quando o valor real da variável é menor que o valor previsto, isto representa uma previsão otimista, que pode ser tanto uma superestimação da receita ou uma subestimação do déficit. De maneira análoga, desvios de execução positivos implicam que a previsão subestima o valor real da variável.

\subsection{Dados em Tempo Real na Literatura Econômica de Política Fiscal}

A literatura empírica com aplicação de dados em tempo real na análise da política fiscal pode ser dividida em três grupos principais, segundo a classificação indicada por Cimadomo (2011): 1) Propriedades estatísticas: as pesquisas listadas nesse grupo analisam as propriedades estatísticas dos desvios dos resultados ex-post em relação às estimativas do ano corrente e do ano anterior das variáveis fiscais. Tais pesquisas apontam que as revisões de dados são significativas e que os dados iniciais divulgados são estimativas viesadas dos valores finais; 2) Reação da política fiscal ao ciclo de negócios: nesse grupo estão inseridas as pesquisas que investigam a reação fiscal em resposta às flutuações cíclicas a partir de dados ex-ante vis-à-vis a avaliação do comportamento cíclico da política a partir de dados ex-post; 3) Deteminantes políticos e institucionais: enquandram-se nesse grupo as pesquisas que estudam os determinantes políticos e institucionais das revisões das estimativas e dos erros de previsão do governo, isto é, desvios entre os resultados ex-post e os planos fiscais do governo. Cada um desses grupos será analisado com mais detalhes. Na sequência, falaremos um pouco sobre os dois primeiros grupos de pesquisas: propriedades estatísticas e reação da política fiscal. O terceiro grupo é o objeto de interesse principal desta tese e será tratado em tópico específico. 


\subsubsection{Propriedades Estatísticas das Revisões dos Dados}

Outra vertente da literatura com a qual esta pesquisa está diretamente relacionada refere-se à precisão das previsões econômicas que são utilizadas na elaboração do orçamento. A análise das previsões econômicas está associada à análise das revisões dos dados.

Conforme Croushore (2011) explica, ao avaliar a previsão das variáveis macroeconômicas, os pesquisadores precisam se preocupar com as revisões de dados. A questão principal a ser avaliada é se as revisões de dados são suficientemente grandes em termos econômicos a ponto de causar problemas aos pesquisadores. Croushore (2011) responde essa pergunta ao afirmar que se as revisões forem pequenas e aleatórias, não há motivos para preocupação ${ }^{4}$. No entanto, revisões de grandes magnitudes geram dificuldades para a análise das previsões macroeconômicas. Por exemplo, ao comparar diferentes modelos de previsão, os pesquisadores precisam estar cientes de que é inapropriado comparar previsões geradas por um modelo atual utilizando o último conjunto de dados disponível com as previsões geradas por um modelo alternativo alimentado com dados disponíveis aos pesquisadores em tempo real e ainda não revisados.

Grandes revisões nas variáveis macroeconômicas como, por exemplo, as revisões realizadas nas taxas divulgadas de crescimento do PIB, revelam que as primeiras estimativas dessa variável não são um retrato confiável da real situação econômica e que, portanto, as decisões políticas adotadas a partir dessas estimativas estarão equivocadas (CUSINATO et alli, 2010b). Apesar das dificuldades envolvidas na revisão de dados, Croushore (2011) reconhece que se trata de uma situação praticamente inevitável e não deve ser entendida como uma crítica às instituições que produzem essas previsões. Como o autor explica, os recursos e as informações disponíveis na produção das previsões são limitados e as revisões também refletem informações novas que não eram conhecidas quando as primeiras estimativas foram realizadas.

\footnotetext{
${ }^{4}$ Croushore (2011) e Croushore e Stark (1999) apresentam a importância dos dados em tempo real para lidar com o problema das revisões nos dados macroeconômicos, especialmente o PIB. Contudo, o objeto de interesse principal dos autores não é a política fiscal, mas o uso de dados em tempo real na análise da política monetária.
} 
Cusinato et alli (2010b) explicam que as instituições que realizam as previsões enfrentam um trade-off entre a rapidez na disponibilidade das informações e a precisão dos dados divulgados. Com o passar do tempo novas informações são incorporadas, fatores sazonais são reestimados, mudanças metodológicas são introduzidas, a série histórica é reconstruída e os dados são revisados com maior precisão.

A preocupação com a precisão das previsões orçamentárias e o impacto destas sobre o resultado da política fiscal tem sido abordada pela literatura econômica sob diferentes aspectos. Nas décadas de 1980 e 1990 o assunto esteve no centro da discussão sobre política fiscal em função da crise fiscal pela qual os Estados Unidos passavam. Com foco principal sob as previsões das receitas de impostos, as pesquisas comparavam as previsões com os resultados alcançados e avaliavam o papel que erros de previsão orçamentários sistemáticos tiveram sob o aumento do déficit acima das projeções oficiais (AUERBACH, 1994). Entre outros aspectos, a literatura interessou-se em explicar os erros de previsão de receitas através da comparação de previsões oficiais com previsões de instituições privadas (AUERBACH, 1999), em identificar as melhores técnicas de previsão entre aquelas de menor viés (FULLERTON Jr., 1989) e em avaliar os efeitos das instituições orçamentárias e políticas sobre o desempenho da previsão fiscal (POTERBA, 1994).

Uma quantidade significativa das pesquisas com foco nos Estados Unidos voltou-se para a análise das experiências dos governos estaduais, destacando-se pesquisas sobre os aspectos institucionais dos processos orçamentários e dos erros de previsão, além das avaliações das técnicas de previsão (STRAUCH, 2000; BRETSCHNEIDER et alli, 1989; CASSIDY et alli, 1989; BRETSCHNEIDER e GORR, 1992; MOCAN e AZAD, 1995; DESCHAMPS, 2004). Há também pesquisas realizadas com foco nos países subdesenvolvidos e em desenvolvimento, sobretudo por ocasião de acordos estabelecidos com o Fundo Monetário Internacional (FMI) como a pesquisa de Golosov e King (2002) que examinaram as previsões de receitas orçamentárias de 126 programas de financiamento firmados entre o FMI e 45 países no período de 1993 a 1999 e identificaram um viés para cima nas receitas estimadas, porém, os autores não abordaram satisfatoriamente as razões para a existência desse viés.

Especial preocupação com a acurácia da previsão fiscal surgiu no âmbito do Pacto de Estabilidade e Crescimento (SGP na sigla em inglês), criado para garantir a disciplina fiscal nos países membros da União Europeia, a propósito do Tratado de Maastricht. O SGP tem 
duas frentes de ação: a vertente preventiva e a corretiva. A primeira vertente visa garantir que a política fiscal seja conduzida de forma sustentável ao longo do ciclo econômico, evitando que os países membros apresentem problemas com déficits e dívidas acima do limite determinado pela União Europeia, que é de no máximo 3\% do PIB para o déficit governamental e $60 \%$ do PIB para a dívida pública. A vertente corretiva, por sua vez, fornece as medidas que os países precisam adotar em casos de déficits excessivos. No âmbito da vertente preventiva, os Estados Membros precisam submeter seus planos orçamentários multianuais para apreciação pela Comissão Europeia e pelo Conselho de Assuntos Econômicos e Financeiros (ECOFIN) que irão avaliar possíveis desequilíbrios orçamentários que representem riscos à sustentabilidade fiscal. A fim de avaliar a performance da convergência e/ou da estabilidade do Estado Membro às metas do SGP, diversos estudos procuram avaliar o desempenho das previsões orçamentárias e de crescimento nas quais se baseiam os planos orçamentários dos Estados Membros. É o caso das pesquisas de Strauch et alli (2004), Brück e Stephan (2006), Jonung e Larch (2004), Beetsma et alli (2009), von Hagen (2010), Pina e Venes (2011), entre outros.

No âmbito da vertente preventiva, os países membros da União Europeia assumem o compromisso de seguir políticas orçamentárias sólidas para se manterem dentro dos limites de dívida e déficit e assegurar a coordenação de suas políticas físcais. Para se manterem na trajetória do cumprimento de suas metas, para cada país é estabelecida uma meta orçamentária de médio prazo conhecido como Objetivo Orçamentário de Médio Prazo (MTO na sigla em inglês). Todos os Estados Membros devem atingir seus objetivos de médio prazo ou estar caminhando em direção a eles, ajustando sua posição orçamentária estrutural a uma taxa de referência de $0,5 \%$ do PIB por ano.

Conforme Strauch et alli (2004) explicam, a Comissão Europeia avalia se os países estão atingindo seus objetivos através dos Programas de Estabilidade (para os membros que já adotaram o Euro como moeda) e os Programas de Convergência (para aqueles que ainda não adotaram a moeda única). Esses programas devem ser submetidos anualmente pelos países membros contendo projeções fiscais e projeções macroeconômicas para os próximos 3 anos. Os Programas de Estabilidade e Convergência (SCP) também precisam conter o primeiro release das variáveis fiscais para o ano t, isto é, a primeira estimativa do valor real da variável para o ano corrente e os primeiros resultados para o ano anterior. Os Programas incluem informações sobre o saldo orçamentário, dívida, arrecadação, despesas, crescimento real e 
nominal do PIB, deflator do PIB, despesa com juros, formação fixa de capital e transferências sociais. Duas vezes por ano, ao final dos meses de março e de setembro, os países membros precisam submeter os dados relacionados ao Excessive Deficit Procedure (EDP), um conjunto de dados fiscais incluindo previsões e resultados. Os relatórios do EDP incluem previsões do saldo orçamentário dos Estados e dos fundos de seguro social, da dívida bruta, do pagamento de juros, das despesas com formação bruta de capital fixo, do PIB a preços de mercado, incluem diferenças entre as contas públicas e as contas nacionais e informações sobre os ajustes de fluxo de caixa. Assim como o SCP, o EDP também apresenta estimativas para o ano corrente (ano t) e estimativas, ou valores finais conforme o caso, das mesmas variáveis para os anos de t-1 a t-4. Segundo Strauch et alli (2004), como os países são avaliados através destes documentos e os que não cumprem as metas podem sofrer sanções, há um claro incentivo a produção de previsões viesadas que são posteriormente revisadas. Os autores interessados em estudar as revisões das previsões orçamentárias buscam mensurar essas revisões.

De Castro et alli (2011) avaliaram as propriedades das revisões dos déficits fiscais realizadas por 15 países da União Europeia no período de 1995 a 2008. Entre outras coisas, os autores identificaram que as revisões são de grande magnitude em percentual do PIB e que os releases preliminares dos déficits são viesados e preditores não eficientes dos releases subsequentes. Vintages mais recentes tendem a apresentar déficits maiores na média. Além disso, os autores identificaram que as revisões no déficit do governo são correlacionadas com informações $e x$ ante e, portanto, podem ser previstas. Garratt e Vahey (2006) analisaram dados em tempo-real do Reino Unido e também verificaram evidências de que as revisões são previsíveis com base em informações ex-ante. Von Hagen e Wolff (2006) analisaram revisões dos dados dos primeiros releases de países da União Europeia. Os autores analisaram a relação entre déficit governamental e mudança na dívida, ou seja, os ajustamentos de fluxo de estoque. Encontraram evidências de que os ajustamentos de fluxo de estoque foram utilizados estrategicamente pelos países membros da União Europeia como forma de se manterem no limite de $3 \%$ de déficit no tempo-real, incorrendo em "contabilidade criativa" para esconderem o déficit orçamentário. 


\subsubsection{Reação da Política Fiscal com Dados em Tempo-Real}

O segundo grupo de pesquisas busca analisar empiricamente os desvios da política fiscal intencional em relação à política fiscal resultante. Em outras palavras, busca-se verificar a reação da política fiscal discricionária às flutuações econômicas utilizando dados em temporeal. A hipótese subjacente é que planos fiscais ex-ante podem diferir significativamente dos resultados observados ex-post.

Em termos gerais, as pesquisas sobre a ciclicidade da política fiscal estimam uma função de reação, relacionando um indicador fiscal ao hiato do produto e a outras variáveis explicativas pertinentes. Tais pesquisas baseiam-se no uso de dados revistos e atualizados, disponíveis expost à ocorrência do evento que se pretende investigar. A principal conclusão dessas pesquisas é que a política fiscal é predominantemente pró-cíclica nos países em desenvolvimento, especialmente na América Latina, enquanto que os resultados para os países desenvolvidos são mais inconclusivos, indicando alguma medida de pró-ciclicidade, embora menos frequente do que nos países em desenvolvimento (LANE, 1998 e 2003; TALVI e VÉGH, 2005; GAVIN e PEROTTI, 1997; COMISSÃO EUROPEIA, 2004; ALESINA e TABELLINI, 2005; AGHION e MARINESCU, 2008).

No entanto, embora as funções de reação da política fiscal estimadas com dados ex-post possam se ajustar razoavelmente bem aos dados, as mesmas não podem ser utilizadas como descrição daquilo que o formulador de política estava intencionado a fazer, haja vista que uma decisão de política fiscal é tomada com base em informações e em previsões disponíveis ao formulador da política no momento em que a executa. Desse modo, dado que as variáveis econômicas estão sujeitas a erros de revisão, e as previsões expostas à incerteza acerca dos desdobramentos futuros e a erros de interpretação das condições macroeconômicas, os dados revistos ex-post e disponíveis após longa defasagem de tempo, podem ser substancialmente diferentes daqueles disponíveis aos formuladores de políticas no momento da tomada de decisão. Em outras palavras, a política fiscal ex-ante, ou a política intencional, da forma como planejada, pode ser substancialmente diferente da política ex-post, dos resultados que são observados com a utilização de dados atualizados, especialmente porque o formulador de política não tem pleno controle sobre o instrumento da política fiscal e, além disso, o resultado final da política fiscal depende de defasagens de tempo longas e imprevisíveis. 
Dessa forma, conforme exposto em Cimadomo (2007), quando o objeto de interesse é o comportamento intencional da política fiscal, deve-se empregar informação em tempo-real para todas as variáveis incluídas na regra de política fiscal que se pretende analisar, a fim de se evitar um erro de julgamento sobre a política. Uma vez identificado que os resultados não condizem com o desejado, deve-se analisar quais os determinantes desses desvios.

As pesquisas que se propõem a este objetivo utilizam os dados em tempo-real que serviram de base para a execução da política fiscal. Utilizando as informações em tempo real, disponíveis ao formulador de política no momento da execução da política, é possível verificar se a reação intencional da autoridade fiscal está de acordo com o comportamento cíclico da política avaliado com dados revistos. Entre estas pesquisas estão o trabalho de Forni e Momigliano (2005) pioneiro no uso de dados em tempo-real para estimar a função de reação físcal. Os autores analisaram dados de 19 economias da OCDE no período de 1993 a 2003, utilizando dados em tempo-real apenas para o hiato do produto, para as demais variáveis foram utilizados dados ex-post. A ideia subjacente é que a situação fiscal atual medida pelo saldo estrutural ex-post é o que importa. Os resultados indicaram uma resposta contracíclica durante as desacelerações.

Cimadomo (2007) foi o primeiro a utilizar dados em tempo real para todas as variáveis contidas na regra de política fiscal, com o objetivo de replicar todas as informações disponíveis ao formulador de política no momento em que as decisões orçamentárias são tomadas. O autor avaliou a reação fiscal de 19 economias da OCDE no período de 1994 a 2006. Enquanto a política fiscal avaliada com dados ex-post foi considerada pró-cíclica, Cimadomo (2007) verificou que, utilizando dados ex-ante, a política fiscal é contracíclica, especialmente durante as expansões, ao contrário do resultado encontrado por Forni e Momigliano (2005). Outros pesquisadores que utilizaram dados ex-ante para analisar a função de reação da política fiscal foram Lewis (2009), Beetsma e Giuliodori (2010), Holm-Hadulla et alli (2012), Golinelli e Momigliano (2006), entre outros. 

Execução

Nesta seção, o objetivo é identificar os determinantes mais frequentes e significantes encontrados na literatura para explicação dos desvios de execução. Esta tarefa será útil para embasar a escolha das variáveis utilizadas no exercício empírico que será realizado no sexto capítulo desta tese.

\subsubsection{Determinantes Econômicos}

Desvios das receitas estimadas podem resultar de previsões construídas a partir de hipóteses erradas. Segundo Goeminne et alli (2005) é possível distinguir entre erros econômicos e erros técnicos. Erros econômicos são aqueles atribuídos à imprecisão na previsão das variáveis macroeconômicas tais como crescimento econômico, inflação, taxa de juros, taxa de desemprego, etc. Erros técnicos são erros de previsão residuais, que captam, por exemplo, mudanças no comportamento dos indivíduos em face da legislação tributária, isto é, um erro técnico pode ocorrer quando houver uma mudança não prevista na base de arrecadação, a partir de mobilidade dos indivíduos dentro das diferentes categorias de renda. Os governos também podem enfrentar choques exógenos, como guerras externas, desastres ambientais, etc., que são imprevisíveis e afetam a arrecadação. Nesse aspecto, Goeminne et alli (2005) afirmam que a qualidade da previsão e o erro resultante estão relacionados à aversão do formulador de política ao risco. Se o formulador de política é avesso ao risco, provavelmente irá considerar a possibilidade de eventos negativos ocorrerem e irá subestimar as receitas esperadas. Ao contrário, se o formulador de política é "amante do risco" possivelmente irá desconsiderar as chances de o evento negativo ocorrer e irá superestimar a arrecadação prevista.

No que concerne aos erros econômicos, Beetsma et alli (2009) explicam que estes podem derivar de surpresas reais, como uma desaceleração completamente imprevista na economia mundial, ou podem resultar de erros deliberados nas projeções econômicas. Em outras palavras, erros na previsão das variáveis macroeconômicas que afetam o resultado 
orçamentário podem resultar de um comportamento oportunista. Governos com instituições fiscais fracas podem adotar a estratégia de window dressing ${ }^{5}$, isto é, adotam medidas que aparentam estar em acordo com as regras fiscais, mas que na verdade apenas maquiam os resultados de curto prazo. Aplicado ao contexto orçamentário, a estratégia de window dressing implica que os governos realizam o planejamento fiscal embasados por expectativas excessivamente otimistas de crescimento do produto. Neste caso, as despesas estimadas são incluídas na lei orçamentária com base em expectativas de receita viesadas. Agindo dessa maneira, os governos conseguem evitar a adoção de medidas de ajustes orçamentários ex-ante e podem atribuir possíveis resultados negativos aos eventos inesperados e à má sorte (COMISSÃO EUROPÉIA, 2005; MILESI-FERRETI e MORIYAMA, 2004, JONUNG e LARCH, 2004).

Diversos autores identificaram a relação entre os erros de previsão do crescimento do produto e o déficit orçamentário, entre eles COMISSÃO EUROPEIA (2005; 2007); JONUNG e LARCH (2004); STRAUCH et alli (2004). A partir da análise de dados dos países membros no período de 1991 a 2002, a Comissão Europeia (2005) identificou uma correlação entre déficits fiscais e o grau de otimismo nas previsões de crescimento do produto utilizadas para realizar as previsões orçamentárias. Os países que sistematicamente basearam suas projeções orçamentárias em projeções de crescimento do produto excessivamente otimistas foram os que registraram déficits fiscais mais elevados. A Comissão Europeia (2007), ao buscar explicações para a ocorrência de saldos orçamentários piores que os planejados em 15 países da União Europeia no período de 1998 a 2006, calculou a sensibilidade do orçamento ao produto e identificou que surpresas negativas no crescimento do PIB respondem por algo entre $1 / 3$ e $1 / 2$ da diferença entre o saldo orçamentário planejado e o saldo realizado. Beetsma et alli (2009) avaliaram os Programas de Estabilidade e Convergência da União Europeia no período de 1998 a 2007 e identificaram que a expectativa de taxa de crescimento do produto positiva para o período $\mathrm{t}+1$ tem um forte efeito positivo sobre o orçamento planejado. Um aumento de $1 \%$ na taxa de crescimento projetada do PIB melhora o ajuste

\footnotetext{
${ }^{5}$ Window Dressing refere-se às ações adotadas para melhorar as demonstrações financeiras. Por exemplo, pode se referir à prática adotada por gestores de fundos de investimento para melhorar a "aparência" de seus portfólios nos períodos em que precisam reportar os resultados financeiros aos acionistas. Fazem isso vendendo os títulos com má performance e adquirindo títulos com melhores resultados. Essas medidas, embora mudem a imagem do fundo, não possui efeito sobre sua performance. Window Dressing também se refere à prática de adiar para o período seguinte o pagamento de despesas já assumidas para que não seja reportado um déficit no caixa no final de um exercício contábil.
} 
orçamentário planejado em mais de $0,5 \%$ do PIB. Em relação à implementação do orçamento, a melhoria é de $0,4 \%$ do PIB.

Jonung e Larch (2004) examinaram como as previsões econômicas subjacentes aos orçamentos dos países membros da União Europeia afetam a situação fiscal dos mesmos. De acordo com os autores, o otimismo persistente na projeção do crescimento econômico na fase de planejamento do orçamento, casado com inércia em ajustar os gastos na fase de execução orçamentária se traduziu em um significante viés deficitário e em uma rápida acumulação de dívida. Usando dados orçamentários de quatro economias europeias (Alemanha, França, Reino Unido e Itália) para o período de 1987 a 2003, os autores identificaram que o viés na previsão fiscal teve um importante impacto de médio-prazo na relação dívida/PIB. Para o período analisado, o viés otimista adicionou cerca de um ponto percentual à relação dívida/PIB na Alemanha e na Itália e cerca de meio ponto percentual na França. Para evitar que esses problemas ocorressem, os autores sugeriram que a previsão de crescimento do PIB fosse atribuída a uma instituição independente do governo e que o governo passasse a utilizar as previsões fornecidas por esta instituição na preparação do orçamento.

Além dos efeitos das projeções do PIB sobre as estimativas fiscais, a literatura identifica outras variáveis concernentes à situação econômica do país que influenciam os desvios de execução orçamentários. É o caso da taxa de desemprego e da taxa de inflação (CHATAGNY e SOGUEL, 2012) e da taxa de inflação e dos erros de previsão do período anterior (SEDMIHRADSKA e CABLA, 2013). Estimativas equivocadas a respeito da taxa de desemprego impactam o nível de renda, o consumo e a arrecadação de impostos. Além disso, dependendo da estrutura de assistência social do país, um aumento na taxa de desemprego pode elevar as despesas da seguridade social, como é o caso do Brasil. Taxa de inflação diferente da esperada tem impacto sobre a arrecadação nominal de receitas: maior inflação, maior arrecadação nominal. De acordo com Sedmihradska e Cabla (2013), os governos ajustam suas estimativas lentamente e os erros de previsão do período anterior tendem a persistir no período seguinte. 
A análise dos determinantes políticos das previsões orçamentárias e dos seus respectivos desvios relaciona-se com a literatura de economia política que estuda os ciclos políticoeconômicos e que estabelece uma relação entre as flutuações econômicas e as motivações políticas. Dentro desta literatura há dois grupos de modelos principais que explicam de que forma o comportamento dos formuladores de política pode influenciar os ciclos econômicos: modelos de oportunismo (opportunistic models) e modelos partidários (partisan models).

Os modelos de ciclos político-econômicos oportunistas assumem que a percepção dos eleitores quanto à realidade econômica influencia a decisão de voto e o resultado das eleições. Os eleitores tendem a recompensar os governantes pelo desempenho econômico positivo e a puni-los quando a economia vai mal (LEWIS-BECK e STEGMAIER, 2000; NADEAU et alli, 2011). Sabendo disso, os partidos que desejam se reeleger procuram entregar resultados econômicos que satisfaçam os eleitores. Estes modelos tiveram origem a partir do artigo seminal de Nordhaus (1975). O pressuposto básico de Nordhaus (1975) é que os eleitores avaliam negativamente o desemprego e a inflação e levam essas variáveis em conta ao decidirem seus votos, abrindo espaço para uma manipulação pré-eleitoral oportunista do ciclo econômico pelos governantes.

De acordo com Nordhaus (1975), a função de preferência dos indivíduos considera a taxa de desemprego agregado e a taxa de inflação e os indivíduos preferem preços estáveis e taxas de desemprego baixas. Apesar de serem racionais em suas preferências, os indivíduos são ignorantes em relação ao trade-off macroeconômico entre inflação e desemprego e tomam decisões políticas com base nas experiências passadas. O eleitor avalia o comportamento do candidato que está no poder comparando-o com o comportamento desejado. Se as condições econômicas tiverem se deteriorado em relação às expectativas, o voto é direcionado para o candidato da oposição. Nordhaus (1975) assume que os candidatos conhecem as preferências dos eleitores e atuam de modo a maximizar a hipótese de reeleição ou de manutenção do partido no poder. Dessa forma, sabendo que a quantidade de votos é função decrescente da taxa de desemprego e de inflação, o candidato à reeleição escolherá um ponto sobre a curva de Phillips que minimiza essas taxas. O desemprego baixo só é mantido no curto prazo. Passado o período eleitoral, o governo reverte as políticas expansionistas adotadas 
anteriormente, gerando um ciclo de negócios político com desemprego e deflação nos anos iniciais do governo, para posteriormente, adotar novas políticas expansionistas no ano de eleição. O resultado é um ciclo econômico cujos pontos de inflexão coincidem com os anos eleitorais.

Outro artigo considerado fundamental sobre ciclos eleitorais é o de Tufte (1978), que verificou que nos Estados Unidos as transferências e pagamentos da seguridade social e aos veteranos sempre aumentavam em anos eleitorais. Após as eleições, eram os tributos e as contribuições que aumentavam.

Os modelos partidários, ao contrário, associam as flutuações econômicas às motivações ideológicas dos partidos dos governantes. Esses modelos foram influenciados pelo artigo de Hibbs (1977). Assim como Nordhaus (1975), o modelo de Hibbs (1977) apoia-se na exploração do trade-off implícito na curva de Phillips na versão aceleracionista. Dessa forma, Hibbs (1977) assume que estabilidade de preços e pleno emprego são metas que não podem ser atingidas simultaneamente, que a relação entre inflação e desemprego é estável no médio e longo prazo e que os formuladores de política conseguem manipular as políticas econômicas para atingir o ponto exato da curva de Phillips que desejarem.

Analisando o padrão das políticas macroeconômicas do pós-segunda guerra associadas com os governos de esquerda e de direita nas democracias capitalistas, Hibbs (1977) identificou diferenças nas combinações de inflação e desemprego escolhida pelos diferentes partidos políticos e concluiu que as políticas macroeconômicas perseguidas por partidos de direita e de esquerda são amplamente de acordo com os interesses econômicos e com as preferências subjetivas das classes sociais que esses partidos representam. Partidos de esquerda com orientação ideológica voltada para a classe trabalhadora atribuem maior importância ao pleno emprego do que à inflação, enquanto partidos de direita voltados à classe média alta atribuem maior prioridade à estabilidade de preços em detrimento ao desemprego. Segundo esse raciocínio, o ciclo econômico resulta da alternância dos diferentes partidos no poder. Quando os partidos de esquerda estivessem no poder, o crescimento econômico e a inflação seriam maiores, porém o desemprego seria menor. O oposto ocorreria quando os partidos de direita assumissem o governo. 
A partir dos anos 80, os modelos de ciclos econômicos passaram a incorporar a hipótese de expectativas racionais, limitando a capacidade dos formuladores de política de influenciar de forma previsível o estado da economia. São representantes dessa abordagem: Rogoff e Sibert (1988), Rogoff (1990), Person e Tabellini (1990) no grupo dos modelos oportunistas e Alesina (1987) no grupo dos modelos partidários.

Enquanto no modelo de Nordhaus (1975), com expectativas adaptativas, e no modelo de Persson e Tabellini (1990), com expectativas racionais, os ciclos político-econômicos são observado através de instrumentos monetários (aumento temporário do produto e emprego em função de expansão na oferta de moeda), nos modelos de Rogoff e Sibert (1988) e Rogoff (1990) os ciclos ocorrem através de medidas fiscais expansionistas, denominado por Rogoff (1990) de ciclos políticos orçamentários (political budget cycles). Rogoff e Sibert (1988) e Rogoff (1990) argumentam que os ciclos eleitorais ocorrem em função de uma assimetria de informação temporária entre o governo e os eleitores. Assumem que o principal fator em uma eleição é a percepção do eleitor quanto à competência de cada partido na provisão de bens públicos. O conceito de competência é usado no seguinte sentido: o governo é mais competente quanto mais serviços públicos for capaz de prover com menor arrecadação de receitas. Os eleitores possuem expectativas racionais, mas só conhecem a competência do governo com uma defasagem de tempo. Os ciclos político-econômicos ocorrem porque os políticos aumentam seus gastos em períodos pré-eleitorais em um esforço para sinalizar maior competência. Somente com uma defasagem de tempo os eleitores percebem que o aumento de gastos terá que ser viabilizado por mais impostos ou por endividamento público no período pós-eleitoral. Os eleitores precisam escolher entre reeleger o governo atual (ou seu partido) ou escolher qualquer outro candidato de oposição. A diferença fundamental entre o governante atual e seus oponentes é que estes últimos apresentam uma desvantagem por não conseguirem sinalizar a competência de suas políticas, uma vez que não possuem os instrumentos de política econômica a sua disposição.

Rogoff (1990) afirma que nos anos em que não há eleições, o governo segue seu plano fiscal. Como os eleitores são capazes de monitorar o governo perfeitamente com um período de defasagem, não há incentivo para causar distorções fiscais nos anos em que não há eleições. A possibilidade de reeleição, no entanto, aumenta a disposição do governante em exercício para distorcer a política fiscal, exarcebando o ciclo político orçamentário. De acordo com o autor, se algum grupo fosse capaz de monitorar o governo e a credibilidade das informações 
transmitidas aos cidadãos, os ciclos políticos orçamentários poderiam não existir mais. Naturalmente que este monitoramento não pode ser provido por uma instituição controlada pelo governo ou por seus concorrentes, uma vez que não seria confiável.

Uma das maneiras apontadas por Rogoff (1990) para mitigar o ciclo político orçamentário é reformular o processo orçamentário de modo que o governante não possa alterar sua regra de política fiscal antes da eleição. Uma sugestão para implementar essa medida é modificar a duração legal do ciclo orçamentário, ou seja, adotar um orçamento bianual, de forma que os gastos públicos e os impostos sejam determinados em anos não eleitorais.

Ao reformular os modelos partidários tradicionais, Alesina (1987) adotou um modelo bipartidário de interação entre partidos políticos com diferentes funções objetivo e agentes determinadores de salário, com expectativas racionais e forward-looking. Os dois partidos divergem em relação ao que consideram como sendo os níveis ótimos de inflação e desemprego. Além disso, os partidos também diferem em relação aos incentivos para gerar surpresas políticas. Alesina (1987) considera que o partido que assume o governo tem pleno controle sobre a política monetária, sendo possível escolher o nível de inflação de sua preferência. Os eleitores são bem informados a respeito dos objetivos de cada partido, no entanto, há incertezas a respeito da preferência dos eleitores e, portanto, o resultado das eleições é incerto. Os salários são determinados em termos nominais com base na expectativa de inflação para o período seguinte, a fim de manter o poder de compra dos indivíduos. Nos anos de eleição, como há incertezas a respeito de qual partido ganhará o pleito, os agentes econômicos determinarão os salários para o período seguinte levando em conta a taxa de inflação esperada ponderada pela probabilidade de vitória de cada partido.

No período imediatamente posterior à eleição, o ciclo econômico ocorrerá e o resultado dependerá de qual partido vencer as eleições. Se o partido que for mais favorável a utilizar a expansão monetária para estimular o crescimento ganhar, haverá inflação acima da esperada e o produto crescerá acima do nível natural. Se, por outro lado, o partido avesso à inflação ganhar, haverá recessão e o desemprego aumentará. Alesina (1987) afirma que quanto menos esperada for a política implementada pelo partido eleito, mais forte serão os efeitos reais de tal política. No entanto, esses efeitos só durarão no período imediatamente posterior às eleições. Nos demais períodos da administração, independente de qual partido esteja no poder, não haverá políticas surpresas e o produto permanecerá em seu nível natural. O modelo de 
Alesina (1987) pressupõe que quanto mais polarizado for o sistema político, maiores serão as flutuações econômicas. Além disso, quanto menos esperada for a política implementada pelo partido eleito, maiores serão os efeitos reais desta política.

Além dos modelos de ciclos políticos econômicos, características políticos-institucionais dos governos influenciam sistematicamente os resultados orçamentários. Entre essas características incluem-se a estrutura do sistema político partidário, as formas de governo, as regras que disciplinam a relação entre os Poderes Executivo e Legislativo e o apoio político ao Executivo.

\subsubsection{Determinantes Institucionais}

Há uma vasta literatura sugerindo que o design do processo orçamentário tem considerável influência sobre o desempenho fiscal dos países. As pesquisas sobre instituições orçamentárias estão inseridas na literatura de economia política, assim como as pesquisas voltadas para a análise dos efeitos das instituições politico-eleitorais sobre o resultado fiscal.

As pesquisas sobre instituições orçamentárias investigam se as regras que regem cada uma das etapas do processo orçamentário contribuem para determinar o saldo fiscal. Entre essas regras, citam-se como exemplo, regras para elaboração das previsões e do orçamento em si; as regras para votação e aprovação do orçamento pelo Congresso definindo a sequência de decisões, se o Congresso irá votar o orçamento linha a linha (bottom-up) ou se irá votar no valor total do orçamento e alocar esse total às diversas categorias de despesas (top-down); as instituições políticas e partidárias como aquelas que disciplinam a ação dos partidos de coalização e os da base de apoio do Governo; a hierarquia entre os agentes com capacidade para alterar o orçamento, isto é, se um único indíviduo, por exemplo, o Ministro da Fazenda, tem poderes para vetar os gastos dos demais ministros; se há limites para a inclusão de emendas parlamentares; se há limites estabelecidos por lei para o tamanho do déficit; se há regras para aumentar a transparência de todo o processo. Enfim, todas as regras que guiam a execução de cada uma das etapas do orçamento, desde sua concepção até sua implementação e controle (ALESINA e PEROTTI, 1995, 1999; VON HAGEN e HARDEN, 1994, 1995; 
POTERBA e VON HAGEN, 1999; HALLEBERG et alli, 2004; VON HAGEN, 1992; ALESINA et alli, 1999).

Ao analisarem os gastos e os déficits públicos nos países da OCDE entre as décadas de 1960 e 1980, Roubini e Sachs (1989) afirmaram que o tipo de governo que assume o poder é muito importante para explicar as políticas de dívida. Os autores identificaram que governos de coalizão multi-partidários tendem a apresentar déficits orçamentários e dívidas maiores do que governos de maioria partidária. A explicação dos autores é que a redução do déficit requer a adoção de medidas fiscais restritivas que para serem aprovadas é necessário haver um consenso político entre os membros do governo. Este consenso é tanto mais difícil de ser alcançado quanto mais fragmentado for o governo. Resultados análogos foram encontrados por Poterba (1994) e Alt e Lowry (1994) em estudos sobre crises fiscais e déficit público nos estados americanos.

Perotti e Kontopoulos (2002) também demonstraram que a fragmentação do processo de formulação e implementação da política fiscal leva a gastos públicos maiores, o que os autores chamaram de "política fiscal frouxa". O processo de formulação e implementação da política fiscal é particularmente frágil resultando em maior frouxidão fiscal quanto maior for o número de tomadores de decisão (decision-makers) e quanto mais descentralizado for esse processo. Há duas razões principais para isso ocorrer. Primeiro, tomadores de decisão individuais não internalizam os custos das políticas que propõem ${ }^{6}$. Segundo, é mais difícil chegar a um consenso sobre as ações que precisam ser implementadas em resposta a choques exógenos.

Perotti e Kontopoulos (2002) identificaram dois componentes de fragmentação, conceitualmente diferentes entre si. O primeiro é o tamanho da fragmentação (size fragmentation) que se refere ao número de tomadores de decisão, e o segundo é chamado de fragmentação de procedimentos (procedural fragmentation) que diz respeito ao conjunto de regras que constitui o processo orçamentário. Adicionalmente, enumeraram duas formas para mensurar a fragmentação: o número de partidos atuantes na coalizão (coalition size) e o número de ministros capazes de criar despesas para o orçamento (cabinet size). As referidas

\footnotetext{
${ }^{6}$ Este problema conhecido na literatura como Common Pool e refere-se ao fato da despesa pública atender às demandas de grupos de interesses particulares, apesar de ser financiada pela coletividade através da arrecadação de impostos.
} 
medidas de fragmentação, juntamente com a ideologia partidária, são determinantes robustos e significantes dos resultados fiscais. Em especial, salários, consumo governamental e transferências são os itens do orçamento mais afetados por esses fatores. Cada partido político é uma entidade razoavelmente coesa representando interesses de grupos específicos nos gastos públicos. O termo coalition size refere-se ao número de partidos de coalizão. Cada Ministro de Estado é uma unidade básica no processo de despesa pública no sentido que participa da formulação do orçamento e demanda uma parcela do orçamento para seus projetos. Nesse aspecto, o termo cabinet size refere-se ao número de Ministros (spending ministers).

O que difere esses dois personagens no processo orçamentário, de acordo com Perotti e Kontopoulos (2002) é que os partidos não estão envolvidos diretamente na formulação do orçamento. No entanto, impactam fortemente as decisões fiscais na medida em que, como protagonistas da coalizão governista, participam da decisão dos planos fiscais que requerem o consenso político para serem implementados. Ao contrário, os Ministros de Estado tem um papel específico no processo orçamentário, pois estão diretamente relacionados ao planejamento e execução das despesas públicas. Dada uma determinada decisão tomada pelos partidos que estão no governo, quanto maior for o cabinet size, isto é, quanto maior o número de Ministros, mais difícil será controlar o crescimento das despesas em resposta a choques exógenos negativos ou implementar uma consolidação fiscal.

Em relação à fragmentação de procedimentos, Perotti e Kontopoulos (2002) afirmam que a disciplina fiscal é mais provável de ser alcançada quando um indivíduo (por exemplo, o Ministro da Fazenda) ou um pequeno comitê determina o orçamento total primeiro. Isso é possível porque o Ministro da Fazenda (ou o comitê em questão) consegue internalizar completamente o custo das despesas, porque eles determinam a despesa total e, através das restrições orçamentárias do governo, determinam também as receitas totais. Determinando o orçamento dessa maneira, espera-se menor fragmentação e, consequentemente, menores gastos públicos.

O que importa para esse resultado, segundo Perotti e Kontopoulos (2002), não é se o gasto total é determinado primeiro ou por último na preparação do orçamento (abordagens topdown ou bottom-up), mas sim que os agentes responsáveis por determinar o orçamento total inicial sejam diferentes dos agentes responsáveis por decidir sua alocação. Ao invés de 
diversos ministros decidindo a despesa total através de um mecanismo de voto de maioria e troca de favores, os ministros passam a desempenhar um papel diferente, porque eles podem barganhar dentro do limite da parcela que lhes cabe de um orçamento com valor final definido.

A segunda noção de fragmentação de procedimentos citada por Perotti e Kontopoulos (2002), diz respeito a forma como os ministros interagem entre si ao darem sugestões para o orçamento. Se a coleta e conciliação dessas propostas for coordenada por um único ministro ou pequeno comitê em negociações bilaterais com cada Ministro, a fragmentação também será menor. Embora os diferentes ministros não internalizem o custo de seus gastos, suas demandas são filtradas e negociadas por um agente que está em condição de internaliza-las.

Von Hagen e Harden (1995) estão entre os pesquisadores que afirmam que a interação das regras processuais prevalecentes em cada etapa do processo orçamentário define a performance fiscal. A análise empírica realizada pelos autores aponta que as características do processo orçamentário que reduzem o viés de gastos devido a ilusão fiscal ${ }^{7}$ são: forte posição do Ministro da Fazenda para impor um conjunto de metas vinculativas no início do processo orçamentário; imposição de fortes limites à inclusão de emendas parlamentar na fase de aprovação do orçamento; o Congresso votar item por item das despesas e um voto global no total do orçamento; um elevado grau de transparência do orçamento; limitada flexibilidade para os ministros durante a fase de implementação do orçamento em contraste a uma forte flexibilidade de ação do Ministro da Fazenda.

De acordo com Hallerberg e von Hagen (1997), a literatura sobre instituições orçamentárias complementa a literatura sobre instituições eleitorais, sendo que esta última restringe o tipo de instituições orçamentárias que o país tem a seu dispor. Um ministro de finanças forte é factível em países com governos de um partido. Em governos multipartidários, comuns em países com representação proporcional, os membros da coalizão não se dispõem a delegar a um único ator a habilidade para monitorar e punir os demais, sendo a negociação de metas de

\footnotetext{
${ }^{7}$ De acordo com von Hagen e Harden (1995) a ilusão fiscal ocorre porque, enquanto o financiamento das atividades do setor público é realizada pelo contribuinte em geral, algumas atividades beneficiam diretamente apenas um menor grupo de contribuintes. Assim, o benefício líquido de um aumento na atividade do setor público é maior do ponto de vista dos beneficiários dessa atividade do que do ponto de vista do contribuinte em geral.
} 
despesas uma alternativa a estes países. A dificuldade em cumprir estas metas explica porque países com representação proporcional são mais propensos a grandes déficits.

Alesina e Perotti (1999) distinguem dois tipos de instituições orçamentárias: a) leis que definem metas numéricas para o orçamento; e, b) regras processuais. Os autores consideram que este último conjunto de regras é mais relevante para a disciplina fiscal. Dentro das regras de procedimento estão as regras que definem o processo de votação do orçamento pelo legislativo e as regras que definem o grau de transparência do processo orçamentário. Os governos tendem a esconder as obrigações, empurrando-as para os orçamentos futuros ou usando fundos que estão fora do orçamento. Alesina e Perotti (1999) alertam para uma prática comum, plenamente relacionada ao assunto desta tese, que é a adoção de projeções das variáveis macroeconômicas excessivamente otimistas, de forma que as receitas sejam superestimadas e os gastos são subestimados. A prática comum ainda atribui à "má sorte" a responsabilidade por déficits inesperados. Uma das formas de lidar com o problema da transparência, além da definição de padrões que devem ser seguidos, na opinão de Alesina e Perotti (1999) é a adoção de agências independentes que forneçam uma garantia na acurácia e nas projeções orçamentárias.

Kyobe e Danninger (2005) investigam os aspectos institucionais do processo de previsão em 34 países de renda baixa no período de 1997 a 2001. O artigo explora os determinantes de três características da prática de previsão: formalidade, simplicidade organizacional e transparência. Na avaliação de Kyobe e Danninger (2005), elevados níveis de corrupção no país estão associados com previsões menos formais e menos transparentes. Os autores também concluem que a existência de contratos de financiamento firmados com o FMI aumenta a formalidade do processo de previsão, mas não melhora o acesso público à informação.

\subsection{Estudos Empíricos com Dados em Tempo Real}

Voltando-se para a vertente da literatura que busca explicar os erros de previsão orçamentários, Goeminne et alli (2005) analisam se diferenças no nível de fragmentação do governo são uteis para explicar os erros de previsão em um conjunto de municípios belgas. Os 
autores focam a análise na fase de preparação do orçamento e demonstram que governos mais fragmentados tendem a ser sistematicamente mais otimistas em relação ao nível de receitas esperadas do que governos de partido único. Nesse aspecto, as surpresas orçamentárias e os déficits "inesperados" ex-post causados por previsões de receita viesadas fornecem uma explicação adicional para o porquê dos déficits serem mais elevados em governos fragmentados.

Goeminne et alli (2005) enumeram três possíveis explicações para que governos mais fragmentados produzam estimativas mais otimistas. A primeira explicação é que governos mais fragmentados, que são legalmente obrigados a apresentarem um orçamento equilibrado e que não podem gastar acima do valor previsto no orçamento, tendem a realizar projeções com viés otimista para acomodar seu comportamento perdulário. Outra explicação é que é mais difícil chegar a um acordo político em um governo fragmentado, de maneira que estimativas mais otimistas facilitam a negociação do projeto orçamentário. Por último, como a fragmentação política em um governo de coalizão tende a reduzir a probabilidade de que determinado partido vença uma eleição, o partido governista pode ser mais otimista em relação às receitas orçadas, incorrendo em déficits fiscais ex-post e restringindo as opções de política de seus sucessores.

Strauch et alli (2004) foram uns dos primeiros a investigarem a performance das projeções orçamentárias associada aos determinantes políticos e institucionais dos erros de previsão. Os autores analisaram os erros de previsão dos saldos orçamentários e de crescimento econômico de 126 programas de estabilidade e de convergência às metas do Tratado de Maastricht submetidos pelos países membros da União Europeia entre os anos de 1991 e 2002. Os autores também avaliaram se fatores institucionais, políticos e econômicos poderiam explicar os vieses encontrados nas previsões. Os resultados encontrados pelos autores indicaram que as previsões exibiram diferentes padrões de precisão e viés entre países, com alguns países apresentando vieses excessivamente otimistas e outros extremamente cautelosos e que, de modo geral, os governos não utilizaram toda a informação disponível de forma eficiente para minimizar o erro de previsão de suas projeções orçamentárias. Os autores verificaram que a posição cíclica e a forma de governança fiscal são importantes determinantes dos vieses nas previsões orçamentárias e de crescimento do PIB. 
Strauch et alli (2004) relataram dois possíveis resultados que podem emergir dessa constatação. Primeiro, os governantes tendem a publicar previsões orçamentárias excessivamente otimistas em anos eleitorais, superestimando o crescimento econômico esperado e o resultado das contas públicas com o objetivo de influenciar o julgamento dos eleitores. Se essas previsões forem criveis, os eleitores podem acreditar que a economia está de fato em expansão e que o governo tem feito um bom trabalho. Dessa forma, espera-se que os erros de previsão orçamentário sejam maiores em anos de eleições. Segundo, o governo pode de fato impulsionar a economia adotando uma política fiscal expansionista no ano eleitoral, mesmo que esta expansão não esteja prevista no orçamento. Como resultado, o saldo orçamentário tende a ser pior em anos eleitorais do que nos demais anos. Por outro lado, o estímulo fiscal também pode atuar no sentido de reduzir os erros de previsão do PIB, à medida que os maiores gastos públicos em anos eleitorais elevarem o crescimento econômico em direção às previsões iniciais. Strauch et alli (2004) ainda estimaram a elasticidade do saldo orçamentário em relação aos erros de previsão do PIB e encontraram que para cada ponto percentual de desvio do crescimento observado em relação à previsão, o saldo orçamentário se desvia, em média, 0,6 pontos percentuais em relação aos planos orçamentários.

Afonso e Carvalho (2013) avaliaram os determinantes dos erros de previsão em 15 países da União Europeia entre 1999 e 2012. As conclusões dos autores apontam que mudanças no imposto de renda afetam os erros de previsão: para previsões feitas em t referentes ao ano t, aumentos no imposto de renda corporativo diminuem os erros de previsão da receita em $t+1$ e t+2. Adicionalmente, um aumento no erro de previsão do PIB diminui o erro de previsão fiscal, o contrário ocorrendo com um aumento no erro de previsão da inflação. Erros de previsão do PIB, governos minoritários, ano eleitoral e imposto de renda coorporativo estão associados com previsões otimistas das receitas. Por outro lado, erros de previsão da inflação e mudanças na taxa de imposto sobre valor adicionado estão associados a previsões relativamente mais prudentes.

Beetsma et alli (2009) usaram dados dos Programas de Convergência e Estabilidade da Europa (PEC) para analisar como os planos fiscais e sua implementação são determinados. Os países analisados são os 14 membros que já pertenciam à União Europeia antes de 2004 (exceto Luxemburgo). Os autores estimaram os determinantes econômicos, políticos e institucionais do planejamento orçamentário e da fase de implementação do orçamento, em especial, dos erros de implementação. Na equação referente ao plano orçamentário, utilizaram 
como variável dependente o saldo orçamentário planejado. Verificaram que o superávit corrente estimado teve forte efeito negativo sobre os superávits planejados, coerente com a ideia de que quanto mais favorável é o estado corrente estimado das finanças públicas, menor é o ajustamento futuro necessário. Uma taxa projetada de crescimento positiva do PIB melhora o saldo orçamentário planejado. Por outro lado, variáveis como a taxa de inflação esperada, o erro de implementação defasado, o nível da dívida estimado e o tamanho do Estado, medido pelo gasto público, não se mostraram significativas. Em relação às variáveis políticas, os autores também incluíram uma dummy para captar os efeitos das mudanças na composição partidária do governo. Verificaram que a mudança de governo aumenta o "aperto" fiscal indicando que novos governos tendem a demonstrar um compromisso com a disciplina fiscal. Outras variáveis políticas como, por exemplo, uma variável que capta o hiato ideológico entre o governo atual e o predecessor e uma dummy para o ano eleitoral não se mostraram significativas.

Na equação relativa à fase de implementação do orçamento, Beetsma et alli (2009) incluíram os erros de implementação defasados e verificaram que há persistência pequena no erro. Adicionalmente, analisaram o impacto do superávit inicial sobre a rigidez orçamentária e verificaram que planos fiscais mais ambiciosos implicam em menor aderência ao plano, ao passo que uma piora no saldo orçamentário inicial aumenta a aderência. Mudanças na composição partidária do governo e no hiato ideológico possuem efeitos negativos sobre o ajustamento orçamentário, reduzindo-o. Por outro lado, surpresas inesperadas na taxa de crescimento do PIB leva a melhoras na implementação do orçamento, reduzindo os desvios.

Beetsma et alli (2009) também mostraram que países pressionados para cumprir seus planos orçamentários adotam medidas criativas para suprimir déficits oficiais, mas que, no entanto, levam a um aumento da dívida pública. Os governos tentam limitar os erros de implementação com mais contabilidade criativa. Beetsma et alli (2009) mostraram ainda que tanto o ajustamento orçamentário planejado quanto a aderência ao plano fiscal são positivamente relacionados à força das instituições fiscais nacionais na forma de um modelo orçamentário de médio prazo forte ou regras fiscais numéricas rígidas. Os autores concluiram dizendo que a melhoria da governança fiscal em nível nacional promove a disciplina fiscal.

Beetsma et alli (2013) exploraram os erros de previsão das fases de planejamento e de implementação orçamentária na Holanda, no período de 1958 a 2009. Diferentemente dos 
demais artigos que utilizam dados em tempo-real, Beetsma et alli (2013) utilizaram dados em tempo-real para investigarem os determinantes dos erros de previsão orçamentários em um único país, analisando um período de tempo de 50 anos, de 1958 a 2009. Os demais estudos que se dispuseram a investigar o assunto usaram um painel de países da União Europeia ou da OCDE em função do pequeno número de observações existentes para um único país.

Beetsma et alli (2013) encontraram que as condições econômicas gerais e o estado das finanças públicas são importantes determinantes tanto das fases de planejamento quanto de implementação do orçamento. Maior expectativa de crescimento e maior dívida pública levaram a planos orçamentários mais austeros. Entretanto, planos mais austeros e saldos iniciais melhores produziramm déficits maiores do que o planejado. O oposto ocorreu com crescimento maior que o esperado. Em relação aos fatores políticos, o saldo orçamentário planejado foi menor em anos eleitorais quando o governo era ideologicamente mais de esquerda e quando o parlamento era mais fragmentado. A fase de implementação resultou em menores erros em anos eleitorais e em governos majoritários. Adicionalmente, os autores identificaram que a maioria das variáveis políticas operou pelo lado das despesas orçamentárias. Por fim, verificaram que com a adoção da abordagem "trend-based budgeting $" 8$ as receitas realizadas foram maiores que as projetadas e a fase de implementação apresentou resultados melhores para o saldo orçamentário em relação à fase de planejamento.

Beetsma et alli (2013) analisaram tanto os determinantes da fase de planejamento quanto os determinantes da fase de execução do orçamento. Na análise da fase de planejamento, avaliaram os determinantes da variável "saldo orçamentário" estimada. O saldo orçamentário inicial (em t-1), o erro de implementação defasado, ou seja, o desvio do saldo orçamentário ocorrido em t-1, a dívida corrente (t-1), a expectativa de crescimento do produto (previsão em t-1 para o período t) e a taxa de crescimento do preço do petróleo (em t-1) em função da particular importância dessa commodity no orçamento Holandês. Com base nas evidências empíricas que encontraram para a Holanda e, contrastando-as com as experiências de outros países Europeus, Beetsma et alli (2013) sugeriram que o melhor caminho para a disciplina fiscal seria a reforma das instituições nacionais, sendo essencial que as previsões necessárias à

\footnotetext{
${ }^{8} \mathrm{O}$ principal instrumento de política utilizado pela abordagem trend-based budgeting é a adoção de tetos multianuais para os gastos públicos, designados para quebrar o vínculo entre mudanças na arrecadação e gastos realizados, além de isolar os gastos orçamentários da influência política e das tentativas de utiliza-los para ajuste fino dos ciclos de negócios.
} 
política fiscal fossem realizadas por instituições independentes, livres de influencias políticas 9 .

Brück e Stephan (2006) avaliaram os determinantes políticos, eleitorais e institucionais da qualidade das previsões de déficit orçamentário tanto de países pertencentes à Zona do Euro quanto dos demais países da OCDE que não pertencem à Eurozona, antes e depois da introdução do Pacto de Estabilidade e Crescimento (SGP). De acordo com os autores, assim como os ciclos políticos orçamentários, os ciclos de previsão podem ser eleitorais, partidários ou institucionais. Em um ciclo de previsão eleitoral, a data da eleição determina os gastos do governo, os planos de tributação e a política de divulgação da informação. Os autores identificaram que a adoção do SGP gerou um incentivo adicional para os governos manipularem suas previsões orçamentárias antes das eleições. Em um ciclo de previsão partidário, o comportamento cíclico deriva das diferentes preferências dos partidos políticos e de seus respectivos eleitores e da orientação política do governo. Os autores encontraram evidências de que a orientação política afeta a qualidade das previsões: governos de direita tendem a realizar previsões mais pessimistas, enquanto os governos de esquerda são mais otimistas em suas estimativas. Verificaram também que os governos de coalizão e os governos de minoria apresentam previsões de déficit orçamentário viesadas, sendo que os governos minoritários da Zona do Euro fizeram previsões claramente otimistas a partir da adoção do SGP. De acordo com os autores, há duas razões principais para que esses resultados sejam mais frequentes nos governos de minoria: primeiro, governos de maioria e de partido único podem se permitir serem impopulares se necessário e ainda ter chances de ganhar as futuras eleições. Segundo, os governos de maioria podem favorecer abertamente seus partidários sem precisar esconder suas ações.

Brück e Stephan (2006) afirmaram que os países da Zona do Euro, quando comparados a outros países da OCDE, trapaceiam ao reportarem as previsões para seus déficits orçamentários antes das eleições. De acordo com os autores, as regras e a fiscalização ocorrida no âmbito da SGP induzem um ciclo de previsão político nos países participantes,

\footnotetext{
${ }^{9}$ Calmfors et alli (2010) argumentam que as instituições fiscais independentes não funcionariam de forma semelhante a um Banco Central independente, ou seja, elas não iriam executar a política fiscal. Ao contrário, poderiam assumir as seguintes funções: a) avaliar os projetos de lei do orçamento e qualquer outra proposta legislativa para garantir a transparência e fiabilidade do orçamento; b) estimar o impacto de medidas fiscais propostas sobre suas próprias projeções macroeconômicas e fiscais; c) monitorar os requerimentos permanentes de equilíbrio orçamentário, teto de dívida, limite de gastos, etc.; d) antecipar riscos fiscais futuros e estresses fiscais que devem ser atendidos com reformas estruturais.
} 
com a criação de incentivos para um esforço fiscal não observável ${ }^{10}$ de natureza negativa, o uso de contabilidade criativa ${ }^{11}$ para esconder seus déficits ou a "trapaça" na divulgação do déficit, especialmente em épocas de eleições.

Utilizando dados do orçamento das quatro maiores economias da União Europeia (Alemanha, França, Reino Unido e Itália) no período de 1987 a 2003, Jonung e Larch (2004) encontraram evidências de um viés de previsão no processo orçamentário que afeta negativamente o desempenho fiscal. Para testarem a influência dos erros de previsão sobre a situação fiscal, os autores incluíram os erros de previsão como uma variável explicativa em uma regressão que examina a relevância empírica das regras fiscais, semelhante a Bohn (1998) ${ }^{12}$. Se os erros de previsão forem relevantes na prática, eles serão significativos na explicação do saldo primário ajustado pelas variações cíclicas (CAPB). Os autores atribuem a performance ruim da consolidação fiscal observada nos países da União Europeia às previsões viesadas de crescimento econômico. Afirmam que os planos orçamentários são recorrentemente elaborados sob projeções excessivamente otimistas das variáveis macroeconômica, para que o orçamento pareça melhor ex-ante e, em seguida, o resultado ex-post, pior do que o esperado, seja atribuído à má sorte (como exposto em Alesina e Perotti, 1999) ou outras circunstâncias negativas inesperadas. Dessa forma, o viés otimista do crescimento econômico se traduz em uma política fiscal mais expansionista do que aquela que seria recomendada sob estimativas não-viesadas, levando a um acúmulo mais rápido de dívidas.

\footnotetext{
${ }^{10}$ No âmbito do SGP, são impostas sanções aos participantes da União Europeia que apresentarem déficits fiscais superiores a $3 \%$ do PIB. As sanções não são aplicadas automaticamente. Para aplicá-las, realiza-se primeiramente uma avaliação longa e detalhada da situação do país deficitário e, posteriormente, o Conselho de Economia e Finanças (ECOFIN) da União Europeia emite suas recomendações. Há situações nas quais as sanções podem ser dispensadas, por exemplo, nos casos em que o país em questão estiver apresentando quedas no PIB. Beetsma e Jensen (2003) afirmam que não apenas os choques exclusivamente exógenos afetam o estado observado da economia, mas, também, o esforço fiscal não observável realizado pelo governo (por exemplo, mais rigor na concessão de benefícios à população, realização de reformas estruturais na economia, etc.). Como as sanções impostas dependem do estado observado da economia, há um problema de moral hazard, uma vez que os esforços fiscais não observáveis são custosos e geram oposição, os governos possuem um incentivo para exercer pouco esforço fiscal.

${ }^{11}$ Milesi-Ferretti (2000) argumenta que regras numéricas sobre o déficit orçamentário podem apresentar alguns efeitos negativos como: forçar o governo a adotar medidas fiscais rígidas mesmo durante as recessões, exarcebando as flutuações macroeconômicas; Ou ainda, encorajar o uso de práticas contábeis duvidosa, conhecidas como "contabilidade criativa", a fim de disfarçar resultados fiscais que sejam diferentes daqueles estabelecidos pela regra.

${ }^{12}$ Utilizando dados dos Estados Unidos no período de 1916 a 1996, Bohn (1998) encontrou evidências de que o superávit primário é uma função crescente da razão dívida/PIB. De acordo com Bohn (1998) este resultado pode ser interpretado como um teste para a sustentabilidade da política fiscal dos Estados Unidos. A política fiscal pode ser considerada sustentável no longo prazo somente se o superávit primário aumentar em resposta a um aumento na dívida pública de forma que a restrição orçamentária intertemporal seja satisfeita.
} 
Para eliminar o viés da previsão, sobretudo o viés otimista, Jonung e Larch (2004) propuseram despolitizar a produção de previsões econômicas subjacentes aos planos orçamentários, atribuindo a tarefa a uma autoridade independente, fato que, na opinião dos autores, poderia ser facilmente justificado uma vez que a produção de previsões econômicas não é o core business do governo e, por requerer conhecimento técnico, pode ser atribuído a experts não-políticos.

Cepparulo et alli (2011) mediram os erros de implementação orçamentária na Itália no período de 1998 a 2009. Os autores mediram o erro de implementação da política fiscal com base em dois estágios diferentes do processo orçamentário: a preparação do orçamento e a discussão e aprovação do orçamento pelo Parlamento. Seguindo Beetsma et alli (2009), Cepparulo et alli (2011) empregaram uma decomposição dos resultados fiscais em planos e implementação e o papel dos acontecimentos econômicos inesperados nos desvios desses planos. Os autores observaram diferenças significativas entre planos e resultados olhando para os itens receitas e despesas do orçamento. A análise dos gastos desagregados revelaram dificuldades do governo italiano em manter os planos de ajustamento resultando em elevação ex-post das despesas. Os autores investigaram quais componentes determinam a variabilidade dos resultados fiscais e encontraram que os erros de implementação das despesas representam cerca de $81 \%$ da variabilidade total. Os autores alertaram que não se poderia esperar que melhorias na implementação da política fiscal partissem da boa vontade política, sendo necessários regras fiscais e controles mais rigorosos. As sugestões são para que sejam adotados planos fiscais de médio prazo mais rigorosos acompanhados por um conjunto de regras fiscais, tais como teto para as despesas e limites para a dívida.

Martins e Correia (2014) investigaram os determinantes econômicos, politicos e institucionais dos desvios da receita total, da despesa total e do saldo orçamentário global de 278 municípios portugueses no período de 2010 a 2012. De acordo com os autores, os erros de execução orçamental sistemáticos explicam o elevado endividamento dos municípios. Os autores alegam que se trata de um trabalho preliminar, em função do curto horizonte temporal investigado. As conclusões iniciais apontam que a variação prevista da receita de um ano para outro explica os desvios da receita total que, por sua vez, explicam os desvios da despesa total e do saldo orçamentário. As previsões são mais otimistas quando existem déficits orçamentários, indicando o desinteresse dos decisores locais em melhorar as finanças públicas. Os resultados também indicam que os desvios negativos da despesa total são 
menores (em valores absolutos) que os desvios negativos da receita total, indicando que a despesa comprometida é maior que a receita liquidada, o que contribui para desvios negativos do saldo orçamental global. Dessa forma, os autores defendem uma maior fiscalização das previsões da receita local na fase de planejamento e da despesa comprometida acompanhar a execução da receita na fase de implementação.

Em relação aos países em desenvolvimento, Lledó e Poplawski-Ribeiro (2013) utilizaram dados do IMF World Economic Outlook como proxy para os dados em tempo real e avaliaram a implementação da política fiscal e os determinantes dos hiatos de implementação, conforme nomenclatura adotada pelos autores, dos países subsaarianos em comparação com outros 171 países, no período de 2004 a 2010. Os resultados mostraram que o tamanho do país é relevante na redução do hiato de implementação. Países maiores são mais hábeis em suavizar choques macroeconômicos e em se manterem nas metas fiscais aos quais estão submetidos. Regimes democráticos, sobretudo aqueles que impõem restrições obrigatórias ao poder executivo, também apresentam menores hiatos de implementação. A implementação dos planos fiscais é mais falha quanto menor o comprometimento do país com o estado de direito e quanto mais fracas são as instituições orçamentárias.

A discussão sobre desvios de implementação e produção de estimativas não viesadas para alimentar o planejamento e a execução da política fiscal está intimamente ligada com a discussão sobre a qualidade das instituições orçamentárias e com a discussão sobre adoção de instituições fiscais independentes. A esse respeito, Pina e Venes (2011) investigaram o papel das instituições fiscais e da governança fiscal na precisão das projeções fiscais de 15 países pertencentes à União Europeia no período de 1994 a 2006, a partir das previsões presentes no EDP (Excessive Deficit Procedure) e nos orçamentos nacionais. Os autores mostraram que as estimativas de déficit público para o ano corrente são afetadas por instituições fiscais e por motivações oportunistas. Especificamente, Pina e Venes (2011) encontraram que as estimativas produzidas nos períodos eleitorais são excessivamente otimistas e que o compromisso com limites numéricos de gastos e com formas mistas de governança fiscal estão associadas com maior prudência e disciplina.

A Tabela 1 resume as principais variáveis utilizadas nas análises empíricas dos determinantes dos desvios de execução. Essas variáveis auxiliarão a seleção daquelas que serão avaliadas como possíveis determinantes dos desvios de execução do orçamento brasileiro. 
Tabela 1 - Sumário das principais variáveis utilizadas na literatura

\begin{tabular}{|c|c|c|c|c|c|c|c|c|}
\hline & 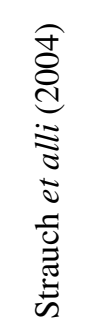 & 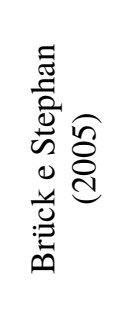 & 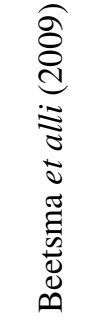 & 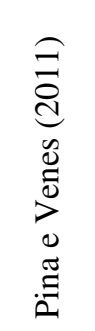 & 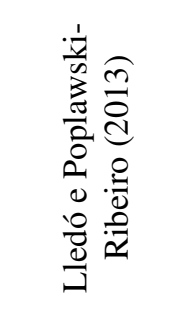 & 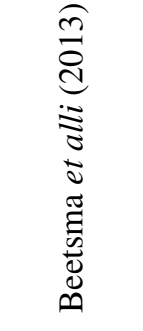 &  & 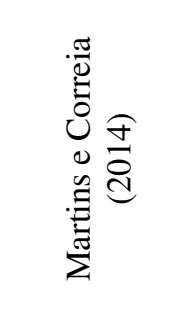 \\
\hline Países & $\begin{array}{l}\text { UE- } \\
15\end{array}$ & $\begin{array}{c}\text { UE-15, } \\
\text { Japão e } \\
\text { EUA }\end{array}$ & $\begin{array}{l}\text { UE- } \\
14^{\backslash 1}\end{array}$ & $\begin{array}{c}\text { UE- } \\
15\end{array}$ & $\begin{array}{c}\text { Países da } \\
\text { África } \\
\text { Subsaariana }\end{array}$ & Holanda & UE-15 & $\begin{array}{c}278 \\
\text { municípios } \\
\text { portugueses }\end{array}$ \\
\hline Período & $\begin{array}{c}1991 \\
\mathrm{a} \\
2002\end{array}$ & $\begin{array}{c}1995 \\
a \\
2003\end{array}$ & $\begin{array}{c}1998 \\
a \\
2007\end{array}$ & $\begin{array}{c}1994 \\
a \\
2007\end{array}$ & $\begin{array}{c}2004 \\
a \\
2010\end{array}$ & $\begin{array}{c}1945 \\
a \\
2009\end{array}$ & $\begin{array}{c}1999 \\
a \\
2012\end{array}$ & $\begin{array}{c}2010 \\
\mathrm{a} \\
2012\end{array}$ \\
\hline Erro previsão PIB & & $X$ & $\mathrm{X}$ & $X$ & $X$ & & $X$ & \\
\hline Ano Eleitoral & $X$ & $\mathrm{X}$ & $\mathrm{X}$ & $\mathrm{X}$ & $\mathrm{X}$ & $\mathrm{X}$ & $\mathrm{X}$ & $\mathrm{X}$ \\
\hline Erro previsão inflação & & & $X$ & & $X$ & & $\mathrm{X}$ & \\
\hline $\begin{array}{l}\text { Governo } \\
\text { Minoritário/Majoritário }\end{array}$ & & $\mathrm{X}$ & & $\mathrm{X}$ & & $\mathrm{X}$ & $\mathrm{X}$ & $\mathrm{X}$ \\
\hline Governo de Coalizão & & $\mathrm{X}$ & & $\mathrm{X}$ & & $\mathrm{X}$ & $\mathrm{X}$ & $\mathrm{X}$ \\
\hline Dívida/PIB & & & $\mathrm{X}$ & & $\mathrm{X}$ & $\mathrm{X}$ & & $\mathrm{X}$ \\
\hline Hiato do Produto & $\mathrm{X}$ & & & $\mathrm{X}$ & & & & \\
\hline Volatilidade do PIB & & & & & $\mathrm{X}$ & & & \\
\hline Governo de Oposição & & & $\mathrm{X}$ & $\mathrm{X}$ & & & & $\mathrm{X}$ \\
\hline Crescimento Esperado PIB & & & $X$ & & & $\mathrm{X}$ & & \\
\hline Fragmentação Partidos & & & & & & $\mathrm{X}$ & & \\
\hline $\begin{array}{l}\text { Regras para Saldo Orçam. } \\
\text { e/ou para Dívida/PIB }\end{array}$ & & & & $\mathrm{X}$ & & & & \\
\hline $\begin{array}{l}\text { Ideologia Partido no } \\
\text { Governo }\end{array}$ & $\mathrm{X}$ & $\mathrm{X}$ & $X$ & $\mathrm{X}$ & & $X$ & & \\
\hline Regras para Despesas & & & & $\mathrm{X}$ & & & & \\
\hline $\begin{array}{l}\text { Formas de Governança } \\
\text { Commitment/Forma Mista }\end{array}$ & $\mathrm{X}$ & & & $\mathrm{X}$ & & & & \\
\hline Regras Fiscais Numéricas & $\mathrm{X}$ & & & $\mathrm{X}$ & & & $\mathrm{X}$ & \\
\hline $\begin{array}{l}\text { Previsão Preparada por } \\
\text { Governo Oposição }\end{array}$ & & & & $\mathrm{X}$ & & & & \\
\hline Impostos Corporativos & & & & & & & $X$ & \\
\hline Saldo Orçamentário & & & & & & & & $\mathrm{X}$ \\
\hline $\begin{array}{l}\text { Alternância de Partido no } \\
\text { Governo/mudança } \\
\text { ideológica }\end{array}$ & & & $X$ & & & $\mathrm{X}$ & & \\
\hline Preço do Petróleo & & & & & & $\mathrm{X}$ & & \\
\hline
\end{tabular}

FONTE: Bibliografia da pesquisa.

${ }^{11}$ Exceto Luxemburgo.

Em resumo, o que as pesquisas citadas indicam é que há evidências de que a situação econômica e os fatores políticos e institucionais influenciam as projeções fiscais. Para lidar com os desvios de previsão, as pesquisas relatadas sugerem a adoção de previsões físcais construídas por agências independentes ${ }^{13}$.

\footnotetext{
${ }^{13}$ Nesse aspecto, também podemos enquadrar esta pesquisa também na vertente da literatura econômica voltada para o estudo das instituições fiscais independentes, uma vez que a literatura indica que a realização das
} 


\subsubsection{Estudos Empíricos para o Brasil}

No Brasil, as pesquisas com dados em tempo real ainda são incipientes e, ao contrário desta tese, o foco e a aplicação dessas pesquisas não é na política fiscal. Na verdade, no Brasil os dados em tempo real tem sido utilizados para a análise das revisões de dados, sobretudo a revisão do PIB. Palis et alli (2004), por exemplo, estudaram os anúncios de revisão do PIB brasileiro. Encontraram que as revisões são relativamente grandes em relação aos países industrializados. Os autores questionam se é apropriado usar dados que passaram por revisões ao avaliar políticas econômicas passadas e avaliar o desempenho das previsões.

Cusinato et alli (2010a) organizaram um conjunto de dados de PIB em tempo real para o Brasil, com 51 séries de dados trimestrais com divulgações do PIB do primeiro trimestre de 1996 ao segundo trimestre de 2008. Os autores investigaram o comportamento das revisões de crescimento do PIB (trimestre/trimestre anterior) e das estimativas de hiato do produto calculados por quatro métodos de extração de tendência: filtro de Hodrick-Prescott, tendência linear, tendência quadrática e modelo de Harvey-Clark de componentes não-observáveis. Os autores encontraram que a revisão absoluta média do crescimento do PIB trimestral é de 0,67 p.p., isto é, em media, o crescimento do PIB é revisado 0,67 p.p. acima ou abaixo do valor inicialmente divulgado. Esse valor tende a decrescer à medida que o período de agregação aumenta. Segundo os autores, em $26 \%$ das vezes, a revisão do crescimento do PIB é maior do que a própria magnitude do dado. Em relação aos 4 tipos de hiato calculados, a revisão absoluta média foi de 0,6 p.p. a 2,3 p. p., sendo que em três dos quatro métodos analisados, a revisão resultou em mudança do sinal do hiato em $30 \%$ ou mais das vezes, e a magnitude de revisão superou a própria magnitude do hiato em $50 \%$ ou mais das vezes. Os autores concluem que, em tempo real, o hiato do produto tende a não ser muito confiável, requerendo cautela dos formuladores de política.

Cusinato et alli (2010b) organizaram um conjunto de dados mensais de produção industrial em tempo real para o Brasil e avaliaram a extensão na qual as séries de crescimento, aceleração e hiato da produção industrial são revisadas. Os autores mostraram que as revisões

previsões macroeconômicas por instituições independentes do poder político tenderiam a reduzir os desvios de implementação orçamentários. 
de crescimento mensal e da média móvel trimestral da produção industrial são substanciais (revisão média absoluta de 0,9 p.p e 0,4 p.p., respectivamente). Com foco na política monetária, os autores alertaram para a existência de limitações no uso dos dados revistos da produção industrial ou do seu hiato para analisar o comportamento passado da política ou para prever a inflação. A alternativa mais adequada, segundo os autores, seria utilizar um conjunto de dados em tempo real, ao invés de utilizar a última série de dados disponível. 
O processo orçamentário ${ }^{14}$ descreve como as decisões a respeito do uso dos recursos públicos são tomadas. De acordo com von Hagen e Harden (1995), o formato institucional do processo orçamentário é essencial na determinação do resultado da política fiscal. A performance fiscal dependerá da flexibilidade dada ao governo e aos parlamentares para se desviarem do orçamento inicial durante suas respectivas participações nas três primeiras fases. Deste modo, o resultado fiscal dependerá da imposição de regras institucionais que conduzam todo o processo orçamentário e que considere a interação das regras com cada uma das etapas de todo o processo. Sendo assim, para auxiliar no alcance do objetivo desta tese, é importante compreender o ambiente institucional no qual o processo orçamentário é conduzido no Brasil $^{15}$. Dessa forma, neste capítulo descreveremos as etapas do ciclo orçamentário adotado no Brasil, seguindo-se a uma explanação do processo de previsão orçamentária.

O ciclo orçamentário em vigor no Brasil contempla as quatro fases descritas por Von Hagen e Harden (1995) e é regulamentado pela legislação orçamentária composta pela Lei 4.320 de 1967, pela Constituição Federal de 1988 (artigos 165 a 169) e pela Lei Complementar n. 101 de 04 de maio de 2000, conhecida como Lei de Responsabilidade Fiscal (LRF).

\footnotetext{
14 Um ciclo orçamentário completo pode ser dividido em quatro estágios, de acordo com a classificação elaborada por von Hagen e Harden (1995): i) Estágio do Planejamento, o qual se inicia com a definição das metas e diretrizes orçamentárias, passando pela previsão de receitas e alocação de gastos entre as diversas unidades governamentais, e finaliza com o envio da proposta de lei do orçamento ao Legislativo para apreciação e votação; ii) Estágio de Aprovação ou Fase Parlamentar, em que o Legislativo irá apreciar as propostas, incluir emendas e aprovar a lei do orçamento. Esta fase pode ser considerada como a fase de barganha entre o governo e o parlamento, na qual os parlamentares irão tentar conseguir o máximo de recursos possível para suas emendas. Isso ocorre, porque os parlamentares costumam superestimar o benefício líquido de aumento dos gastos a medida que eles veem apenas a parte da crescente carga tributária que recai sobre seus círculos eleitorais e não sobre toda a população do país e, por isso, tendem a aumentar os gastos previstos; iii) Fase de Implementação, em que as receitas são arrecadadas e os gastos são realizados. Von Hagen e Harden (1995) e von Hagen (2002) alertam que nessa fase surgem novas oportunidades para os parlamentares e o executivo se desviarem da lei do orçamento e atender demandas de gastos adicionais, seja pela adoção de leis orçamentárias suplementares, por transferências de fundos entre as rubricas do orçamento ou ainda ultrapassando o limite de gastos imposto pelo lei do orçamento. A aderência à Lei do Orçamento dependerá de duas forças opostas: o grau em que as ações do governo durante o ano fiscal são vinculadas ao orçamento aprovado e o grau de flexibilidade para responder a eventos imprevisto; e, finalmente, a última fase: iv) Fase de Controle ex-post, em que uma corte de auditores ou outra instituição similar irá avaliar se os gastos e as receitas realizadas estiveram de acordo com a lei do orçamento.

${ }^{15} \mathrm{O}$ processo de planejamento e execução do orçamento público brasileiro será apresentado apenas na medida necessária para atender aos objetivos deste trabalho. Para uma análise completa deste processo, vide Giuberti (2012) cuja tese analisou em profundidade o processo institucional de elaboração, aprovação e execução do orçamento sob a ótica da disciplina fiscal e dos resultados observados para a política fiscal vigente para o período de 1965 a 2010.
} 
A Constituição Federal determina que o planejamento orçamentário da Administração Pública ocorra a partir de três instrumentos principais, cada um deles com funções bem delimitadas e integradas entre si, cuja elaboração é de responsabilidade indelegável do chefe do Poder Executivo de cada ente federativo: o Plano Plurianual de Investimentos, a Lei de Diretrizes Orçamentárias e a Lei Orçamentária Anual. Os três instrumentos são detalhados a seguir.

\subsection{Plano Plurianual de Investimentos (PPA)}

Trata-se de um instrumento de planejamento de médio prazo que deve nortear todos os demais planos e programas do governo, em âmbito nacional, regional e setorial. Constam do PPA os objetivos estratégicos do governo, com a descrição de todos os programas e políticas públicas que o governo se propõe a cumprir e as estimativas de recursos necessários para viabiliza-los. É elaborado no primeiro ano de mandato presidencial para vigorar pelos quatro anos subsequentes (até o final do primeiro ano do mandato seguinte).

O projeto de lei do PPA deve ser enviado ao Congresso Nacional até o dia 31 de agosto do primeiro ano de mandato, onde será apreciado pelas duas casas legislativas em uma comissão mista e permanente composta por 10 senadores e 30 deputados federais (COMISSÃO MISTA Permanente de Planos, ORÇAMENTOS Públicos e Fiscalização - CMO), até a data de encerramento da sessão legislativa. Durante a fase de avaliação pelo Congresso, antes de iniciada a votação, podem ser propostas emendas ${ }^{16}$ ao plano. Uma vez aprovado, o projeto de lei segue para a sanção do Presidente da República, que poderá sancioná-lo ou vetá-lo, total ou parcialmente, devendo o veto ser avaliado pelos deputados e senadores. Mantido o veto, o projeto de lei volta para a promulgação do Presidente.

A LDO estabelece a ligação entre o Plano Plurianual e os orçamentos anuais. Dentre as metas do governo estabelecidas no PPA, a LDO estabelece quais metas serão prioridade para o

\footnotetext{
${ }^{16}$ No projeto da PPA, cada deputado federal e cada senador pode apresentar até 10 emendas, enquanto as comissões permanentes da Câmara e do Senado e as bancadas estaduais podem, cada uma, apresentar até 5 emendas.
} 
exercício financeiro subsequente (ano civil), compatibilizando-as com as estimativas de disponibilidade financeira dadas pelo orçamento.

De acordo com a Constituição Federal (art. 165, § $2^{\circ}$ ), a LDO compreende as metas e prioridades da administração pública federal, incluindo as despesas de capital para o exercício financeiro subsequente, orienta a elaboração da lei orçamentária anual, dispõe sobre as alterações na legislação tributária e estabelece a política de aplicação das agências financeiras oficiais de fomento.

Com a promulgação da Lei de Responsabilidade Fiscal (Lei Complementar $n^{\circ} 101$ de 2000), a LDO recebeu novas funções, dentre as quais, passou a dispor também sobre: i) Equilíbrio entre receita e despesa; ii) O estabelecimento de critérios e formas de limitação de empenho, no caso em que a arrecadação da receita seja inferior ao esperado e comprometa as metas de resultado primário e nominal previstas para o exercício; iii) $\mathrm{O}$ controle de custos e a avaliação dos resultados dos programas financiados com recursos do orçamento; iv) A transferência de recursos a entes públicos e privados; v) A definição da meta de superávit primário a ser alcançada a fim de reduzir as despesas com pagamento de juros e o montante da dívida; vi) O limite à expansão de despesas obrigatórias de caráter continuado.

A primeira etapa na aprovação da LDO é o encaminhamento pelo Presidente da República da proposta para as diretrizes orçamentárias, isto é, o Executivo encaminha ao Congresso o Projeto de Lei de Diretrizes Orçamentárias (PLDO). Esse projeto deve ser compatível com as metas e prioridades definidas no PPA e deve ser acompanhado de anexos específicos determinados pela legislação.

A partir da LRF, a LDO passou a conter dois anexos fundamentais ao planejamento fiscal: o Anexo de Metas Fiscais e o Anexo de Riscos Fiscais. O primeiro estabelece as metas anuais que o setor público deve alcançar a respeito das receitas e despesas, resultados nominal e primário e estoque da dívida, além de apresentar avaliações e comparativos a cerca do cumprimento das metas do período anterior. O último, por sua vez, apresenta os passivos contingentes ${ }^{17}$ e outros riscos que possam impactar negativamente o cumprimento das metas fiscais, incluindo as providências a serem tomadas caso os riscos se concretizem.

17 Passivos contingentes são dívidas que ainda não estão reconhecidas e/ou contabilizadas, mas que, por decisão judicial ou legal, poderão vir a aumentar a dívida pública (PASSOS e CASTRO, 2009). 
Os riscos fiscais que podem atrapalhar o cumprimento da meta são os riscos orçamentários e os riscos de dívida. Os riscos orçamentários referem-se à possibilidade das receitas e despesas estimadas no Projeto de Lei Orçamentária Anual (PLOA) não se confirmarem durante a execução do orçamento em função do surgimento de fatos novos e não previstos à época da elaboração do orçamento. Entre as variáveis macroeconômicas que afetam os recursos arrecadados pela União, cujas estimativas são utilizadas na projeção das receitas, estão o nível de atividade da economia, a taxa de inflação, a taxa de câmbio, a taxa de juros e a massa salarial. As variações na receita podem ocorrer em função de mudanças na conjuntura interna e/ou externa ocorridas após a elaboração do PLOA, com impactos nas variáveis macroeconômicas que afetam a arrecadação.

Nesse aspecto, o Anexo de Riscos Fiscais mede a sensibilidade da arrecadação de impostos e contribuições administrados pela Receita Federal do Brasil às mudanças de 1 ponto percentual nos parâmetros macroeconômicos que os afetam, sendo que os parâmetros que mais impactam a arrecadação de tributos são as variações no nível de atividade econômica e as variações na taxa de inflação. De acordo com estimativas contidas no Anexo de Metas Fiscais da Lei de Diretrizes Orçamentárias de 2015, a cada $1 \%$ de variação no PIB, a arrecadação das receitas administradas pela Receita Federal (exceto previdenciárias) variam 0,63\%. Quanto à sensibilidade em relação à inflação, a cada $1 \%$ de alteração na taxa de inflação, a receita administrada (exceto previdenciária) varia 0,59\%. Para mensurar os efeitos da inflação sobre a arrecadação, utiliza-se uma combinação de índices chamado Índice de Estimativa da Receita (IER), que atribui 55\% à taxa média do Índice Nacional de Preços ao Consumidor Amplo (IPCA) e 45\% à taxa média do Índice Geral de Preços - Disponibilidade Interna (IGP-DI). A ponderação indica a correlação do índice com a arrecadação realizada nos exercícios anteriores.

O efeito das variações na taxa de câmbio e na taxa de juros sobre a arrecadação é menor ${ }^{18}$, respectivamente de $0,10 \%$ e $0,04 \%$. De acordo com a explicação dada na LDO 2015, esse efeito menor ocorre porque a taxa de câmbio influencia diretamente apenas os impostos

\footnotetext{
${ }^{18}$ Essa interpretação nem sempre foi assim. O Anexo de Riscos da LDO 2004, por exemplo, classificou como "significativo" o impacto da flutuação cambial sobre a projeção das receitas. Na ocasião, os impostos afetados pelo câmbio, Imposto de Importação, IPI sobre importados e IR incidente sobre remessas ao exterior contribuíam com 8,2\% da receita administrada estimada para 2004.
} 
relacionados à importação, tais como o Imposto de Importação, o Imposto Sobre Produtos Industrializados (IPI) importados e o Imposto de Renda (IR) incidente sobre as remessas ao exterior. Já a taxa de juros afeta a arrecadação de IR sobre as aplicações financeiras e a arrecadação dos impostos pagos em atraso, sobre os quais incide juros. Esse cálculo não leva em conta o efeito indireto da variação cambial e da taxa de juros sobre a renda nacional e, consequentemente, sobre a arrecadação dos impostos atrelados à renda.

Os riscos da dívida dividem-se em riscos relativos à administração da dívida e os riscos decorrentes dos passivos contingentes. A administração da dívida pública é afetada por 2 riscos: os riscos de refinanciamento e os riscos de mercado. Ambos os riscos afetam a razão dívida líquida do setor público/produto interno bruto (DLSP/PIB) que representa um dos principais indicadores de endividamento e solvência do governo. O risco de refinanciamento refere-se à possibilidade de elevação nos custos de financiamento da dívida no curto prazo, ou até mesmo na possibilidade de o Tesouro Nacional não conseguir honrar seus compromissos. O risco de mercado refere-se ao risco das flutuações nas variáveis macroeconômicas, em especial a taxa básica de juros, a taxa de câmbio e de inflação, afetarem tanto o custo quanto o estoque da dívida pública. Nesse aspecto, o Anexo de Riscos Fiscais mede a sensibilidade da dívida pública à mudança em um ponto percentual nas variáveis macroeconômicas relevantes, em especial, taxa de câmbio, taxa de juros e taxa de inflação.

O Anexo de Metas Fiscais, por sua vez, deverá conter as metas anuais, em valores correntes e constantes, relativas às receitas e despesas primárias, resultado nominal, resultado primário e montante da dívida pública para o exercício a que se referirem e para os dois exercícios seguintes. As metas anuais devem estar fundamentadas em expectativas a respeito das variáveis macroeconômicas que influenciam no resultado fiscal, especialmente a evolução da atividade econômica, da variação dos preços, do câmbio e da taxa de juros. Os parâmetros macroeconômicos estimados para os três exercícios seguintes devem estar claros no documento.

O Anexo de Metas Fiscais deve conter também: a) avaliação do cumprimento das metas relativas ao ano anterior; b) o demonstrativo das metas anuais, com memória e metodologia de cálculo que justifiquem os resultados pretendidos; c) comparação com as metas fixadas nos três exercícios anteriores; d) evolução do patrimônio líquido dos três últimos exercícios; e) 
avaliação da situação financeira e atuarial da previdência social e do regime próprio de previdência dos servidores públicos e do Fundo do Amparo ao Trabalhador e dos demais fundos públicos e programas estatais de natureza atuarial; f) demonstrativos da estimativa e compensação da renúncia de receita e da margem de expansão das despesas obrigatórias de caráter continuado $^{19}$ (LRF, art. $4, \S 1^{\circ}$ e $\S 2^{\circ}$ ).

Além dos Anexos de Metas e de Riscos Fiscais, a LDO também contem o Anexo com relação de despesas que não serão objeto de limitação de empenho (LRF, art. 9), e o anexo contendo os objetivos das políticas monetária, creditícia e cambial, com os parâmetros e as projeções para seus principais agregados e variáveis, além das metas de inflação para o exercício seguinte (LRF, art. $\left.4^{\circ}, \S 4^{\circ}\right)$.

A tramitação da LDO, desde a chegada a CMO até a sanção da lei pelo Presidente, segue as mesmas normas estabelecidas para o PPA. Qualquer modificação na LDO proposta pelo Legislativo não poderá ser incompatível com o PPA. O prazo para que o projeto de lei seja encaminhado ao Congresso para apreciação é até 15 de abril, e até 17 de julho para que retorne para o Executivo, sendo que o Congresso não pode entrar em recesso enquanto o projeto de Lei não seja aprovado.

O orçamento é a materialização do planejamento (PISCITELLI, 2006). A LOA apresenta a previsão de receitas e fixa as despesas do ano subsequente, disciplinando todas as ações do governo, isto é, nenhuma despesa pública pode ser autorizada fora do orçamento. Gastos que ultrapassem o limite estabelecido pelo orçamento dependem de receita adicional não esperada, de autorização para abertura de créditos suplementares e/ou contratação de operações de crédito.

\footnotetext{
${ }^{19}$ A LRF (art. 17) define como despesas obrigatórias de caráter continuado a despesa corrente, derivada de lei, medida provisória ou ato administrativo normativo, que fixe para o ente público a obrigação legal de sua execução por um período superior a dois exercícios fiscais. Os atos que criarem ou aumentarem essas despesas deverão conter estimativas do impacto orçamentário-financeiro no exercício em que a despesa deva entrar em vigor e nos dois subsequentes e demonstrar a origem dos recursos para seu custeio que deverão vir do aumento permanente de receita ou redução permanente de despesa. Deve-se ainda comprovar que a expansão da despesa não afetará as metas fiscais.
} 
O orçamento é elaborado pelo Executivo através da Secretaria do Orçamento Federal (SOF) vinculada ao Ministério do Planejamento, Orçamento e Gestão. O ciclo orçamentário e a fase de elaboração se iniciam com a expedição pela SOF das regras gerais para a elaboração do projeto de lei orçamentária do ano subsequente. Cada um dos três poderes (Executivo, Judiciário e Legislativo), o Ministério Público da União e a Defensoria Pública da União possuem autonomia para elaborar suas propostas orçamentárias, obedecendo ao limite de despesas fixado pela SOF com base na LDO. Posteriormente, a SOF recebe as necessidades de gastos de cada uma dessas unidades (Gabinetes, Secretarias, etc.) considerando o limite de gastos estabelecido. Na sequência, a SOF consolida essas informações, estima a receita ${ }^{20}$ que o governo espera arrecadar, com base nas estimativas das variáveis macroeconômicas fornecidas pela Secretaria de Política Econômica do Ministério da Fazenda, e compatibiliza a previsão de receita com as expectativas de gastos. Finalmente, com base no PPA e na LDO aprovada, a SOF elabora a proposta orçamentária para o ano seguinte e a encaminha à Presidência da República, a quem cabe encaminhar a proposta ao Poder Legislativo dentro dos prazos legais estabelecidos.

O Executivo deve encaminhar o projeto de Lei do Orçamento Anual (PLOA) ao Congresso para apreciação da Comissão Mista Permanente até o dia 31 de agosto. A LDO consolida as exigências legais e define a estrutura e organização dos orçamentos. Além dos quadros orçamentários consolidados e anexos orçamentários discriminando detalhadamente fontes de receitas e aplicação desses recursos, a proposta de lei orçamentária deve ser acompanhada por mensagem do Presidente da República contendo: a) Resumo da política econômica do país; b) Análise da conjuntura econômica, com avaliação do cenário macroeconômico esperado para o exercício subsequente e suas implicações sobre a proposta orçamentária; c) Atualização das informações a respeito dos objetivos da política monetária, creditícia e cambial, com os parâmetros e as projeções para seus principais agregados e variáveis e as metas de inflação para o exercício seguinte; d) Resumo das políticas setoriais do governo; e) Avaliação das necessidades de financiamento do Governo Central, explicitando as receitas, despesas e os resultados primário e nominal implícitos no Projeto de Lei Orçamentária do ano a que se refere, do ano corrente e do ano anterior, apresentando a metodologia de cálculo utilizada em todos os itens e os parâmetros macroeconômicos que embasaram as estimativas. Em relação

\footnotetext{
${ }^{20}$ A metodologia utilizada para previsão das receitas será apresentada em seção específica.
} 
às empresas estatais, a mensagem presidencial deverá conter justificativa da estimativa e da fixação, respectivamente, dos principais agregados da receita e da despesa e o demonstrativo sintético, por empresa, do Programa de Dispêndios Globais informando as fontes de financiamento, a previsão de sua respectiva aplicação e o resultado primário estimado para essas empresas, com a metodologia de apuração do resultado.

A Constituição Federal também estabelece que o projeto de lei orçamentária seja acompanhado de demonstrativo regionalizado do efeito sobre as receitas e despesas, decorrente de isenções, anistias, remissões, subsídios e benefícios financeiros, tributários e creditícios (art. 165, $\S 6^{\circ}$ ). Adicionalmente, da mesma forma que exigido na LDO, o projeto de lei orçamentária deve conter as medidas a serem realizadas para a compensação a renúncias de receita e aumento de despesas obrigatórias de caráter continuado.

O Orçamento Geral é composto por três orçamentos: a) $\mathrm{O}$ orçamento fiscal referente aos Poderes da União, seus fundos, orgãos, entidades da administração direta e indireta, inclusive fundações instituídas e mantidas pelo poder público; b) $\mathrm{O}$ orçamento de investimento das empresas em que a União, direta ou indiretamente, detenha a maioria do capital social com direito a voto ${ }^{21}$; c) $\mathrm{O}$ orçamento da seguridade social de todas as entidades e órgãos da administração direta ou indireta, inclusive fundos e fundações.

Após o Congresso Nacional receber o projeto de lei orçamentária, inicia-se o rito legislativo específico $^{22}$ para análise do referido projeto, que fica a cargo exclusivo da CMO. Inicialmente, a CMO realiza audiências públicas com Ministros ou demais representantes do Ministério de Planejamento, Orçamento e Fazenda e representantes dos órgãos e entidades integrantes das áreas temáticas ${ }^{23}$ para debater o projeto.

\footnotetext{
${ }^{21}$ Em relação às empresas estatais independentes, consta do orçamento aprovado no Congresso apenas suas despesas com investimentos. O orçamento global dessas empresas, denominado Programa de Dispêndios Globais (PDG) é aprovado somente no âmbito do Chefe do Poder Executivo, por decreto. Cabe ao Departamento de Coordenação e Governança das Empresas Estatais (DEST) a elaboração do orçamento de investimentos e do Programa de Dispêndios Globais das estatais.

${ }^{22}$ Conforme explicado por Greggianin (2005), a apreciação dos projetos de leis orçamentárias pelo Congresso é diferente do processo de apreciação das demais leis por haver prazos definidos, regras e restrições especiais quanto às emendas e aprovação da lei orçamentária.

${ }^{23}$ A CMO organiza a análise do Orçamento por áreas temáticas. A Resolução CN 3/2015 menciona 16 áreas setoriais, cada uma delas contando com um sub-relator: i) Transporte; ii) Saúde; iii) Educação e Cultura; iv) Integração Nacional; v) Agricultura, Pesca e Desenvolvimento Agrário; vi) Desenvolvimento Urbano; vii) Turismo; viii) Ciência e Tecnologia e Comunicações; ix) Minas e Energia; x) Esporte; xi) Meio Ambiente; xii) Fazenda e Planejamento; xiii) Indústria, Comércio e Micro e Pequenas Empresas; xiv) Trabalho, Previdência e Assistência Social; xv) Defesa e Justiça; e xvi) Presidência, Poder Legislativo, Poder Judiciário, MPU, DPU e Relações Exteriores.
} 
Na sequência o Relator da Receita, auxiliado pelo Comitê de Avaliação da Receita, avalia a metodologia e as estimativas de receitas contidas no Projeto de Lei Orçamentário. A Resolução n. 1/2006 do Congresso Nacional estabelece que eventuais reestimativas de receitas são elaboradas nessa etapa, a partir da análise da conjuntura, da evolução da arrecadação até o momento da análise, de mudanças na legislação tributária em curso no Congresso e de reavaliação no cenário macroeconômico esperado. Nesta etapa também são avaliadas e emite-se parecer às emendas às receitas e de renúncia de receita. O Relatório da Receita é votado antes da apresentação do Relatório Preliminar do Relator-Geral do Orçamento.

Em seguida, o Relator-Geral apresenta o Relatório Preliminar à CMO, contendo uma visão geral do projeto de lei e as regras que deverão orientar o processo de apreciação e alteração do projeto no âmbito do Congresso Nacional, como por exemplo, a compatibilidade do projeto com o PPA, com a LDO e com a LRF, as regras para apresentação e apreciação das emendas e a composição da Reserva de $\operatorname{Recursos}^{24}$ para o atendimento das emendas apresentadas. $\mathrm{O}$ Relatório Preliminar e as emendas ao Relatório são votadas na CMO. Após a aprovação, o relatório passa a se chamar Parecer Preliminar. Na sequência, inicia-se a fase de recebimento das emendas às despesas.

As emendas à despesa são classificadas como de remanejamento, de apropriação ou de cancelamento. Emendas de apropriação são aquelas que propõem acréscimo de dotação em programação existente no PLOA ou inclusão de nova programação e, como fonte de recursos, a anulação de dotações da Reserva de Recursos e de outras definidas no Parecer Preliminar. Emenda de remanejamento é a que propõe acréscimo ou inclusão de dotações e utiliza como fonte exclusiva de recursos a anulação equivalente de dotações constantes do projeto, exceto as da Reserva de Contingência ${ }^{25}$. Por fim, emenda de cancelamento é aquela que propõe, exclusivamente, a redução de dotações constantes do projeto.

\footnotetext{
${ }^{24}$ A Resolução n. 1/2006 do Congresso Nacional estabelece que a "Reserva de Recursos será composta dos eventuais recursos provenientes da reestimativa das receitas, da Reserva de Contingência e outros definidos no Parecer Preliminar, deduzidos os recursos para atendimento de emendas individuais, de despesas obrigatórias e de outras despesas definidas naquele Parecer" (art. 56).

${ }^{25}$ A LRF (art. 5) determina que o projeto de lei do orçamento contenha uma reserva de contingência para atender passivos contingentes e outros riscos e eventos fiscais imprevistos. Os valores alocados sob a rubrica de reserva de contingência constituem uma dotação global sem destinação prévia. São recursos orçamentários livres que podem ser utilizados a qualquer momento em situações não antecipadas no planejamento orçamentário, mediante abertura de créditos adicionais e suplementações.
} 
A Constituição Federal (art. 165, $\S 3^{\circ}$ ) estabelece que emendas ao projeto de lei do orçamento só poderão ser aprovadas se: a) forem compatíveis com o PPA e com a LDO; b) se houver indicação da origem dos recursos necessários aos gastos adicionais, sendo que apenas são admitidos recursos provenientes de anulação de despesas, exceto as que incidam sobre: i) dotações para pessoal e seus encargos; ii) serviço da dívida; iii) transferências tributárias constitucionais para os demais entes da Federação; ou, c) se relacionem com a correção de erros ou omissões; ou d) com dispositivos do texto do projeto de lei. Além disso, as despesas adicionais devem atender aos seguintes critérios: a) Respeito ao limite de gastos com pessoal; b) A criação de despesas de duração continuada não pode ocorrer sem que haja uma fonte segura de receitas; c) Não se devem criar despesas sem que haja receita correspondente; d) $\mathrm{O}$ orçamento deve ser equilibrado; e, e) Não haja desvio de recursos para interesses privados.

As emendas podem ser individuais ou coletivas. Durante a fase de apreciação da PLOA pelo Congresso, cada Deputado Federal (513 no total) e cada Senador (81) podem apresentar até 25 emendas individuais para modificar a proposta de despesa do Executivo. As emendas coletivas se dividem em: emendas de bancadas estaduais, que podem atingir um máximo entre 18 e 23 dependendo o número de parlamentares da bancada e emendas de comissões permanentes do Congresso. Cada comissão pode apresentar até 8 emendas, sendo 4 de apropriação e 4 de remanejamento. Todas as comissões mistas permanentes também podem apresentar emendas, incluindo a CMO, o que pode gerar um conflito de interesses por se tratar o órgão responsável pela análise e aprovação das emendas aprovadas; e, por fim, as emendas de bancadas regionais que podem ser até o limite de 2 por bancada.

Neste ponto é relevante tratarmos das intervenções do Congresso Nacional no projeto de lei orçamentária.

Como mencionado, durante a fase de apreciação da proposta orçamentária, o Congresso costuma promover alterações no projeto original por meio de emendas ao texto e, principalmente, às despesas. Contudo, de acordo com a Constituição Federal (Art. 166, § 3 e $\S 4)$, não pode haver aumento no valor total da despesa constante do projeto encaminhado pelo Poder Executivo, exceto se houver erros ou omissões nas receitas, devidamente comprovados. Da mesma maneira a LRF (Art. $12, \S 1^{\circ}$.) admite a reestimativa de receita por parte do Poder Legislativo em caso de comprovado erro ou omissão de ordem técnica ou legal. Por sua vez, a 
Resolução $n^{\circ} 1$ de 2006 do Congresso Nacional afirma que atualizações da receita poderão ser propostas em caso de eventual revisão de parâmetros e da legislação tributária, com base em avaliação do Comitê de Avaliação da Receita. Em resumo, a legislação estabelece que o Congresso somente poderá elevar as receitas previstas para comportar novas despesas se houver erro de caráter técnico ou legal na estimativa encaminhada pelo Governo (ou, na interpretação do próprio Congresso, revisão de parâmetros macroeconômicos e da legislação tributária). Essa é a forma mais frequente pela qual o Congresso costuma elevar a receita total prevista, isto é, ao supor que o crescimento do PIB será maior que o previsto no projeto de lei encaminhado pelo Executivo, o Congresso abre margem para ampliação das receitas esperadas e, dessa forma, amplia também as despesas autorizadas no orçamento.

Na avaliação de Rezende e Cunha (2003) e Figueiredo e Limongi (2008), a partir da LRF houve uma inversão na atuação do Congresso perante a apreciação do orçamento. Com a Lei de Responsabilidade Fiscal o Congresso precisou se adaptar à escassez de recursos e às exigências de disciplina fiscal. Nessa adaptação, precisou mudar sua forma de intervenção no projeto de lei orçamentária. Antes da LRF, primeiro as emendas eram recebidas e, somente depois, os recursos para atendê-las eram auferidos. Da maneira como é feito agora, primeiro os recursos são auferidos e depois as emendas são processadas.

Na avaliação de Figueiredo e Limongi (2008), a criação do Comitê de Avaliação de Receitas, institucionalizado em 2001 através da Resolução n. 1 do Congresso (art. 19), representa uma atuação mais responsável do Congresso na definição de gastos e no esforço para encontrar novas receitas. Antes desse Comitê, a prerrogativa de reestimar receitas estava concentrada nas mãos do Relator-Geral. Com a criação do referido comitê, essa tarefa ficou a cargo de um órgão coletivo com normas e procedimentos estabelecidos. Para conseguir incluir novas despesas no orçamento, o Congresso passou a depender da comprovação de recursos não previstos na proposta enviada pelo Executivo.

Ainda em relação à tramitação da proposta orçamentária no Congresso, o Presidente da República também poderá propor modificação no PLOA $^{26}$ enquanto a votação da parte cuja alteração é proposta não é iniciada (CF, art. $165, \S 5^{\circ}$ ). Na avaliação de Sanches (1995), essa flexibilidade atribuída ao Executivo compromete o funcionamento do Congresso Nacional. A

\footnotetext{
${ }^{26}$ Este artigo também se aplica a PPA e a LDO.
} 
cada mensagem que o Executivo encaminha, os prazos precisam ser reabertos, inclusive para a apresentação de novas emendas, retardando a aprovação da lei orçamentária. Outro problema identificado pelo autor é que essa prática tende a levar o governo a não tratar o planejamento orçamentário com a devida seriedade, uma vez que pode modificá-lo a qualquer tempo. Por essa razão, Sanches (1995) sugere que as modificações do Projeto de Lei só deveriam ser admissíveis em situações de caráter pontual e desde que o Executivo produzisse um orçamento embasado em um processo consolidado de planejamento e programação.

As emendas são discutidas e votadas pela CMO. Na CMO também ocorre a apresentação, discussão e votação individual dos relatórios setoriais, preparados no âmbito das 16 áreas setoriais. Após a aprovação dos relatórios setoriais, o Relator Geral compila as decisões setoriais e as alterações promovidas pelas emendas no Relatório Geral e o submete à CMO para deliberação. O Relatório aprovado constitui o Parecer da CMO que é encaminhado ao Plenário do Congresso Nacional para discussão e votação pelas duas Casas, em sessão conjunta.

Os congressistas podem propor destaques ${ }^{27}$ para a votação em separado de emendas até o dia anterior à discussão, com o objetivo de propor mudanças no parecer aprovado na CMO. O Orçamento deve ser votado até o encerramento da sessão legislativa em dezembro, porém esta data não é obrigatória. Após a votação, a CMO elabora a redação do texto final que recebe o nome de Autógrafo e o encaminha ao Presidente da República, que pode sancionar ou vetar, total ou parcialmente, o texto aprovado pelo Congresso. Se houver veto, o Congresso deverá apreciá-lo. Por fim, a lei orçamentária é promulgada e publicada no Diário Oficial da União.

\subsection{Breves Notas sobre a Previsão da Receita Orçamentária}

A importância da previsão de receitas e a necessidade de tornar transparente a metodologia de cálculo utilizada as estimativas estão expostas na Lei de Responsabilidade Fiscal. No Art. 11, a LRF afirma que a instituição, previsão e efetiva arrecadação dos tributos são requisitos

\footnotetext{
$27 \mathrm{O}$ destaque é um procedimento de votação que tem por finalidade retirar partes do projeto para permitir a votação em separado. A parte destacada só volta a integrar o projeto se for aprovada nessa votação em separado. Os interessados em manter o trecho destacado é que devem obter o quorum necessário para reinseri-lo no texto. Caso contrário, o trecho destacado é excluído.
} 
essenciais na gestão fiscal. Sobre a metodologia para previsão da arrecadação, o Art. 12 da LRF determina que "As previsões de receita observarão as normas técnicas e legais, consideração os efeitos das alterações na legislação, da variação do índice de preços, do crescimento econômico ou de qualquer outro fator relevante e serão acompanhadas de demonstrativo de sua evolução nos últimos três anos, da projeção para os dois seguintes àquele a que se referirem, e da metodologia de cálculo e premissas utilizadas." Ao encaminhar o projeto de lei orçamentário ao Congresso, o Executivo deve fornecer a metodologia de cálculo utilizada para estimar as receitas esperadas. Na verdade, cada ente da Federação é responsável pela previsão de sua própria arrecadação de tributos.

A previsão da arrecadação requer o uso de uma metodologia apropriada e o fornecimento dos parâmetros macroeconômicos necessários para as estimativas. No âmbito Federal, cabe à Secretaria de Política Econômica (SPE) do Ministério da Fazenda estimar os parâmetros utilizados na elaboração do Projeto de Lei Orçamentária da União. Os Estados e Municípios costumam utilizar, além de previsões próprias, os parâmetros utilizados pelo Governo Federal e as expectativas fornecidas pelo mercado financeiro. A grade de parâmetros macroeconômicos estimada pela SPE compreende a previsão de diversas variáveis como variação real e nominal do PIB, inflação medida pelos índices de preço IPCA, INPC e IGPDI, taxas de juros Selic e TJLP, taxa de câmbio, massa salarial, volume de importações, produção e preço da indústria de transformação, preço dos combustíveis, entre outros.

A metodologia mais adequada para projetar o comportamento da arrecadação para os períodos seguintes depende da espécie de receita que se quer projetar. No caso das receitas administradas pela Receita Federal do Brasil (RFB), exceto receitas previdenciárias, a previsão é realizada por meio de um método conhecido como método incremental ou de indicadores, cuja metodologia encontra respaldo no Art. 12 da LRF.

De acordo com a Secretaria do Tesouro Nacional (Manual da Receita, 6º Edição, 2008) o método de indicadores baseia-se na série histórica de arrecadação das receitas (que compõe a base de cálculo), a qual se aplicam, mês a mês e por tributo, os indicadores relativos a preço (efeito preço), a quantidade (efeito quantidade) e de mudanças de aplicação de alíquota em sua base de cálculo (efeito legislação). Para cada tributo há um índice de preço e quantidade que melhor se ajustam. A qualidade da previsão das receitas está diretamente ligada à precisão das previsões dos diversos indicadores utilizados nos cálculos 
A metodologia é representada pela seguinte fórmula:

$\mathrm{REC}_{\mathrm{t}}=\mathrm{BASE}_{\mathrm{t}-1}(1+\mathrm{EP})(1+\mathrm{EQ})(1+\mathrm{EL})$

Em que:

$\mathrm{REC}=$ Arrecadação prevista para determinado período $\mathrm{t}$

BASE $=$ Base de cálculo.

$(1+\mathrm{EP})=$ Índice de Variação de Preços.

$(1+\mathrm{EQ})=$ Índice de Variação de Quantidade

$(1+\mathrm{EL})=$ Efeito Legislação

A Base de cálculo considera a série histórica de arrecadação do mesmo período do ano anterior (t-1), corrigida por fatores atípicos como as receitas extraordinárias ou pontuais.

Quando o projeto de lei orçamentário é elaborado, apenas a realização da receita até o mês de junho de cada ano é conhecida. O TCU (2012) esclarece como a proposta orçamentária para o ano seguinte é elaborada nessa situação:

a) Para os seis primeiros meses do ano seguinte, a base utilizada é a arrecadação efetivamente realizada no período de janeiro a junho do ano corrente;

b) Para o segundo semestre do exercício seguinte, a base utilizada é a arrecadação realizada no mesmo período do ano anterior ao corrente.

De acordo com a RFB (BRASIL, 2014), nos tributos para os quais não se dispõe de indicadores de preços específicos e para aqueles que se ajustam melhor aos indicadores gerais, o indicador de preço utilizado é um índice ponderado (IEP) representado por $55 \%$ do Índice de Preços ao Consumidor Amplo (IPCA) e 45\% do Índice Geral de Preços Disponibilidade Interna. Outros preços utilizados no índice, de acordo com o tributo que se quer estimar, são: a variação da taxa média de câmbio, crescimento da massa salarial, variação da taxa de juros do overnight, variação da taxa de juros de longo prazo (TJLP), dentre outros. Em relação ao índice de quantidade, quando não há um indicador específico para o tributo, utiliza-se o PIB como indicador de quantidade. Outros indicadores podem ser o volume das importações, em dólar, número de contribuintes, nível de emprego, entre outros. 
A vantagem principal desse método é que não há necessidade de séries históricas longas. A RFB utiliza como base de cálculo a arrecadação efetivamente realizada no ano anterior. Outra vantagem é o método é de fácil aplicação, permitindo frequentes reestimativas sempre que houver mudanças em suas variáveis e permite agregar qualquer variável nova que possa influenciar a arrecadação. Campos (2009), por outro lado, identifica algumas desvantagens importantes, por exemplo, o fato de o método ser trabalhoso, já que há um grande número de tributos (incluindo as subclassificações tributárias), e diversos índices de preços e de quantidade envolvidos. O referido autor também cita como desvantagem a necessidade de excluir as arrecadações atípicas ocorridas e a dificuldade em obter um índice de alterações na legislação tributária. Adicionalmente, o método funciona melhor em ambiente de estabilidade econômica, por ser dependente da arrecadação do período anterior e da correta previsão dos indicadores utilizados. Na opinião de Campos (2009), as desvantagens citadas colaboram para que as previsões fornecidas pelo método dos indicadores sejam imprecisas, gerando erros de previsão significativos.

\section{Implementação e Controle do Orçamento}

A Lei de Responsabilidade Fiscal determina que o poder público avalie periodicamente seu desempenho no cumprimento das metas fiscais e revise as estimativas macroeconômicas e de arrecadação, controlando a realização das despesas com vistas à adequa-las às receitas e à meta de superávit primário. Dessa forma, a gestão orçamentária deve garantir que eventuais desvios em relação às previsões sejam corrigidos ao longo do exercício fiscal, compensando os riscos orçamentários por meio da realocação e redução de despesas, com o objetivo de que a meta fiscal seja cumprida.

O primeiro passo após a publicação da Lei Orçamentária é a publicação pelo Poder Executivo, em até 30 dias, do decreto com a programação financeira e o cronograma de execução mensal de desembolso dos pagamentos relativos às dotações previstas na LOA em vigor e os restos a pagar dos exercícios anteriores. ${ }^{28} \mathrm{O}$ cronograma de desembolso deve ser compatível com as

\footnotetext{
${ }^{28}$ A despesa orçamentária possui três fases: empenho, liquidação e o pagamento propriamente dito. O empenho é o registro da despesa no momento da contração do serviço ou aquisição do bem, produto, obra que o originou. A liquidação consiste no reconhecimento do direito adquirido pelo credor, mediante a confirmação de que o serviço para o qual foi contratado, ou a obra ou bens adquiridos foram entregues. Os restos a pagar dividem-se em processados e não-processados. Os restos a pagar não processados são as despesas que foram empenhadas,
} 
expectativas de arrecadação. Após a publicação do decreto de programação, inicia-se a fase de execução do orçamento. Além do cronograma mensal de pagamentos, o decreto de programação financeira contém um desdobramento das receitas primárias previstas em metas bimestrais de arrecadação.

A LRF (Art. 9) determina que sejam feitas avaliações bimestrais das previsões de arrecadação e cumprimento das metas e, ao final de cada bimestre, se a revisão dos parâmetros macroeconômicos e a situação corrente da economia indicarem que a receita estimada será menor que a inicialmente prevista na Lei Orçamentária, as metas de arrecadação são revistas e as despesas discricionárias são ajustadas para o novo nível previsto de arrecadação para garantir o ajuste da execução orçamentária às metas fiscais. Para isso, o Executivo adota o expediente de contingenciamento ${ }^{29}$ de despesas, através do qual há limitação de empenho e movimentação financeira de despesas discricionárias, segundo critérios definidos na LDO que, entre outras coisas, devem especificar quais categorias de despesas poderão ser objeto de contingenciamento e como os valores contingenciados serão distribuídos entre os três poderes da União. As despesas que constituam obrigações constitucionais e legais, incluindo às destinadas ao pagamento do serviço da dívida e aquelas ressalvadas pela LDO não poderão sofrer limitação de empenho ${ }^{30}$. O bloqueio das despesas públicas deve ocorrer enquanto não houver garantia de receita que lhe financie. Posteriormente, caso seja identificado que as receitas serão maiores que aquelas inicialmente estimadas, as dotações contingenciadas serão recompostas proporcionalmente, conforme for ocorrendo a retomada da arrecadação.

Adicionalmente, a Lei de Responsabilidade Fiscal (Art. 9, $\S 4^{\circ}$ ) estabelece que ao final dos meses de maio, setembro e fevereiro, o Executivo demonstre e avalie o cumprimento das metas fiscais de cada quadrimestre em audiência pública na CMO. Por conta dessa necessidade, o decreto de programação também apresenta uma estimativa do resultado primário do Governo Federal que deverá ser alcançado a cada quadrimestre.

mas ainda não liquidadas até o dia 31 de dezembro do exercício de referência. Os restos a pagar processados são formados pelas despesas liquidadas, mas ainda não pagas até o dia 31 de dezembro.

${ }^{29} \mathrm{O}$ contingenciamento orçamentário é operacionalizado por meio de decretos editados ao longo do exercício fiscal, através dos quais se estabelecem limites globais para o conjunto de despesas discricionárias a cargo de cada órgão ou unidade orçamentária, cabendo aos ministros definir os programas e ações que serão afetados no âmbito de seus respectivos ministérios.

${ }^{30}$ Os novos decretos de programação, com os valores previstos atualizados, podem ser publicados em qualquer momento do ano e não apenas durante as avaliações exigidas pela LRF. 
O bloqueio das despesas públicas deve ocorrer enquanto não houver garantia de receita que lhe financie. Posteriormente, caso seja identificado que as receitas serão maiores que aquelas inicialmente estimadas, as dotações contingenciadas serão recompostas proporcionalmente, conforme for ocorrendo a retomada da arrecadação.

A LRF autoriza o contingenciamento de empenho quando houver comprovada redução da arrecadação em relação à estimada na LDO e na LOA (Art. 9). Conforme Silva (2004) destaca, a Lei de Responsabilidade Fiscal é bastante clara ao especificar que é a realização da receita abaixo do programado e não a execução da despesa que legitima a limitação de empenhos. Somente nesse caso, o contingenciamento poderia ser utilizado. Entretanto, ao longo dos anos, o recurso do contingenciamento foi sendo usado de forma intensiva pelo Poder Executivo, gerando questionamentos a respeito de sua prescrição.

O mecanismo de contingenciamento caminha lado a lado com os erros de previsão orçamentários. Como bem explicado por Rezende (2009), o Executivo pode elaborar o orçamento com base em expectativas superestimadas a respeito das variáveis macroeconômicas que determinam as projeções de receitas e despesas. Os parlamentares podem rever essas projeções de receita, de modo a abrir espaço para acomodar suas emendas, que geralmente são superestimadas para ficarem protegidas do contingenciamento. Posteriormente, o Executivo, alegando inconsistência do orçamento aprovado com as metas fiscais, contingencia as despesas aprovadas.

Em outras palavras, a possibilidade de contingenciar despesas de forma discricionária permite que o orçamento seja aprovado com base em previsões de arrecadação artificialmente infladas a fim de acomodar o maior volume possível de despesas, tendo em vista que somente despesas autorizadas no orçamento podem ser realizadas. Esse instrumento permite reduzir possíveis conflitos entre os parlamentares na alocação dos recursos e possíveis conflitos entre os parlamentares e o Executivo ao permitir a aprovação de um número maior de emendas. No entanto, após a aprovação do orçamento pelo Legislativo, o Poder Executivo assume o controle da execução orçamentária e se utiliza do contingenciamento para limitar a realização das despesas, não executando o orçamento da forma como foi aprovado pelo Congresso. Isso é possível porque o orçamento aprovado pelo Congresso tem caráter autorizativo, porém não mandatório. Em outras palavras, o fato de determinada despesa constar do orçamento autoriza, porém, não obriga o Executivo a realizá-la. A efetiva realização da despesa fica à 
cargo do Poder Executivo a quem cabe autorizar o seu empenho, liquidação e pagamento. Merece registro, no entanto, o fato de que o caráter não impositivo do orçamento refere-se apenas às despesas discricionárias, haja vista que a maior parte do orçamento público já é de execução obrigatória.

O mecanismo de contingenciamento permite que o Executivo imponha suas prioridades aos demais poderes e o Ministério Público da União. Isso ocorre porque, embora o Congresso possa modificar a proposta orçamentária preparada pelo Executivo, acrescentando, suprimindo ou modificando determinadas rubricas da PLOA, o Executivo corre poucos riscos de que sua proposta seja desfigurada pelo Congresso. Mesmo que determinadas emendas sejam incluídas no PLOA, o Chefe do Executivo poderá vetá-la. Ainda que sejam sancionadas, não há garantias de que as emendas serão executadas, haja vista que podem ser contingenciadas. Isso é possível uma vez que Além do poder de veto, o Executivo pode não realizar despesas aprovadas, contingenciando dotações e retendo liberações financeiras, e, conforme Piscitelli (2006) alerta, direcionando o orçamento de acordo com seus próprios interesses e conveniências.

A partir da LDO de 2014, passou a vigorar o regime de orçamento (parcialmente) impositivo em relação às emendas individuais, que até então eram consideradas discricionárias. A Emenda Constitucional (EC) 86/2015 perpetuou essa alteração tornando obrigatória a aprovação das emendas individuais até o limite de 1,2\% da receita corrente líquida prevista na PLOA, distribuído em partes iguais por parlamentar, sendo metade deste percentual destinado a ações e serviços públicos de saúde. O projeto de lei orçamentário deve prever os recursos para financiamento dessas emendas. Além da aprovação das emendas até o limite citado, a referida emenda também torna obrigatória a execução orçamentária e financeira das emendas individuais até o montante de $1,2 \%$ da receita corrente líquida realizada no exercício anterior. A execução dessas emendas somente deixarão de ter execução obrigatória se houver impedimentos de ordem técnica ${ }^{31}$. Nesse caso, as justificativas para a não execução das

\footnotetext{
31 De acordo com a Portaria Interministerial 40/2014, art. $1 \S 2^{\circ}$, impedimentos de ordem técnica podem ser entendidos como elementos que impeçam o curso regular da realização da despesa referente às emendas individuais impositivas, como por exemplo: i) Não indicação do beneficiário e respectivo valor da emenda no prazo estabelecido; ii) Não apresentação do plano de trabalho no prazo; iii) Não atendimento dos ajustes solicitados no prazo; iv) Desistência do proponente; v) Incompatibilidade do objeto indicado com a finalidade da ação orçamentária; vi) Incompatibilidade entre o objeto indicado e o programa do órgão ou entidade executora; vii) Falta de razoabilidade dos valores entre a emenda e a execução do projeto; viii) Não aprovação do Plano de Trabalho.
} 
emendas deverão ser formalmente enviadas ao Legislativo no prazo de 120 dias da promulgação da lei orçamentária. Adicionalmente, se a reestimativa da receita e da despesa indicar que a meta de resultado fiscal estabelecida na LDO não será cumprida, a execução das emendas obrigatórias poderá ser reduzida na mesma proporção da limitação incidente sobre as demais despesas discricionárias.

Apesar da EC 86/2015, é preciso destacar que o orçamento continua tendo caráter autorizativo, não sendo obrigatório no seu todo. Apenas a parte relativa às emendas individuais é que se tornou impositivo. As emendas coletivas de bancadas estaduais e das comissões continuam discricionárias. Além disso, devemos acrescentar o fato de que a imposição é sobre 1,2\% da Receita Corrente Líquida que é o somatório das receitas tributárias deduzidos os valores das transferências constitucionais e, que, portanto, não se refere ao total da receita orçamentária. Em 2014, por exemplo, a Receita Corrente Líquida atingiu R \$ 641,6 bilhões, aproximadamente $11 \%$ do PIB, enquanto a Receita Corrente Bruta foi de R $\$ 1.243,3$ bilhões $(22,52 \%$ do PIB).

No entanto, Leite (2015) alerta que a execução obrigatória das emendas individuais possibilita atender os interesses eleitorais dos próprios parlamentares, em detrimento ao interesse global da lei orçamentária. Outro problema que podemos identificar é que essa medida enfraquece a lei orçamentária, pois cria uma fonte adicional de conflito de interesses, haja vista que, uma vez que as emendas individuais sejam liberadas, o Congresso não terá motivação para cobrar o cumprimento das demais normas orçamentárias.

A execução orçamentária, embora ocorra após discussão e aprovação pelas duas Casas Legislativas, é conduzida de acordo com os interesses e objetivos estabelecidos pelo Executivo. Essa capacidade de executar seletivamente as emendas dos congressistas (mesmo considerando a imposição dada pela EC 86/2015) dota o Executivo de uma poderosa moeda de troca que pode ser utilizada para adquirir apoio dos parlamentares (ALSTON et alli, 2008). Mas, apesar da possibilidade do Executivo conduzir a execução do orçamento de forma discricionária, seu raio de manobra é pequeno devido à elevada rigidez orçamentária. Em outras palavras, a flexibilidade de ação do Governo Federal no orçamento é prejudicada pelo excessivo grau de vinculação de receitas e pelo elevado nível de despesas obrigatórias pela legislação, que reduzem a flexibilidade alocativa da política fiscal. No Projeto de Lei Orçamentário de 2014, por exemplo, as despesas discricionárias, sob as quais o Governo tem 
liberdade de decisão, representaram aproximadamente $20 \%$ do total de despesas primárias (inclusive transferências e benefícios da Previdência) e cerca de 5\% do PIB. Embora em valores proporcionais frente às despesas obrigatórias, as despesas discricionárias pareçam uma fração pequena das despesas primárias, é em termos absolutos que a quantia se mostra significativa, representando cerca de R\$260,00 bilhões em 2014. Ademais, como Contijo (2010) destaca, esses recursos são importantes por constituírem-se principalmente de gastos com investimentos e outras despesas correntes, que são os grupos de interesse de praticamente todas as emendas parlamentares ao orçamento.

Além do contingenciamento, outros expedientes legais permitem que o orçamento executado seja diferente do orçamento aprovado, é o caso dos créditos adicionais e dos restos a pagar. Embora o objetivo seja garantir flexibilidade para que o orçamento possa ser gerido em situações imprevistas, os referidos mecanismos fazem com que o processo de previsão e planejamento fiscal assumam papéis de segunda categoria na gestão pública.

O orçamento aprovado também pode ser alterado através do mecanismo de créditos adicionais $^{32}$ que são autorizações de despesas que não foram previstas na Lei Orçamentária ou foram previstas insuficientemente, decorrentes de falhas não identificadas na LOA, mudanças de rumo das políticas públicas, variações de preços de mercado dos bens e serviços a serem adquiridos pelo governo e situações emergenciais imprevistas. As novas emendas devem ser custeadas por cancelamentos de outras despesas ou arrecadação superior à esperada. Havendo necessidade de realizar despesas acima do limite estabelecido pela LOA, a Presidência da República, a pedido da SOF, abre crédito por decreto ou encaminha projeto de lei ao Congresso para aprovação .

\footnotetext{
${ }^{32}$ Os créditos adicionais são previstos na Lei 4.320 de 1964, art. 40 a 46. Classificam-se em: i) Suplementares que são os destinados a reforço de dotação orçamentária insuficiente no orçamento anual; ii) Especiais, que são os destinados a despesas para as quais não há dotação orçamentária específica (desde que conste nas prioridades da LDO e nas metas do PPA); iii) Extraordinários que são os destinados a despesas urgentes e imprevistas. Os créditos suplementares e especiais dependem da existência de recursos disponíveis para custea-los. São autorizados por lei e abertos por decreto executivo.
} 


\section{OS DESVIOS DE EXECUÇÃO ORÇAMENTÁRIOS DE 2002 A 2015: VISÃO GERAL}

\subsection{Introdução}

Neste capítulo, apresentaremos um panorama dos desvios de execução das variáveis envolvidas no processo orçamentário: receita, despesa, taxa de crescimento do PIB e dos principais parâmetros macroeconômicos que fundamentam a preparação e aprovação do orçamento. Dada a limitação de dados anuais passíveis de serem usados para esta finalidade, em especial por se tratar de um número pequeno de anos sob análise, a análise será realizada a partir de análise gráfica e das seguintes medidas de erro: Erro Médio (EM), Erro Quadrado Médio (EQM) e Raiz do Erro Quadrado médio (REQM).

O capítulo está dividido em 3 seções além desta introdução. Na primeira seção, descrevemos como foi realizada a construção da base de dados utilizada nesta pesquisa. Na sequência, apresentamos por meio de gráficos os desvios de execução da receita, da despesa e das variáveis macroeconômicas que embasam a elaboração e execução do orçamento. Por fim, apresentamos os resultados dos cálculos do EM, EAM e REQM.

\subsection{Construção da Base de Dados em Tempo Real}

A base de dados utilizada nesta pesquisa foi construída a partir das informações contidas nos documentos oficiais relativos ao processo orçamentário. Os principais documentos utilizados foram: as propostas de Leis Orçamentárias, os Relatórios gerados pelo Congresso por ocasião da apreciação dessas propostas, as Leis Orçamentárias Anuais e seus anexos, os Decretos Presidenciais de Programação Orçamentária e Financeira, relatórios de avaliação das metas fiscais, relatórios do Tesouro Nacional e da Secretaria da Receita Federal e demais documentos oficiais resultantes das fases de planejamento, aprovação e implementação orçamentária. A Ilustração 1 a seguir apresenta uma relação dos documentos fiscais e as etapas do processo orçamentário nos quais esses documentos são produzidos. 


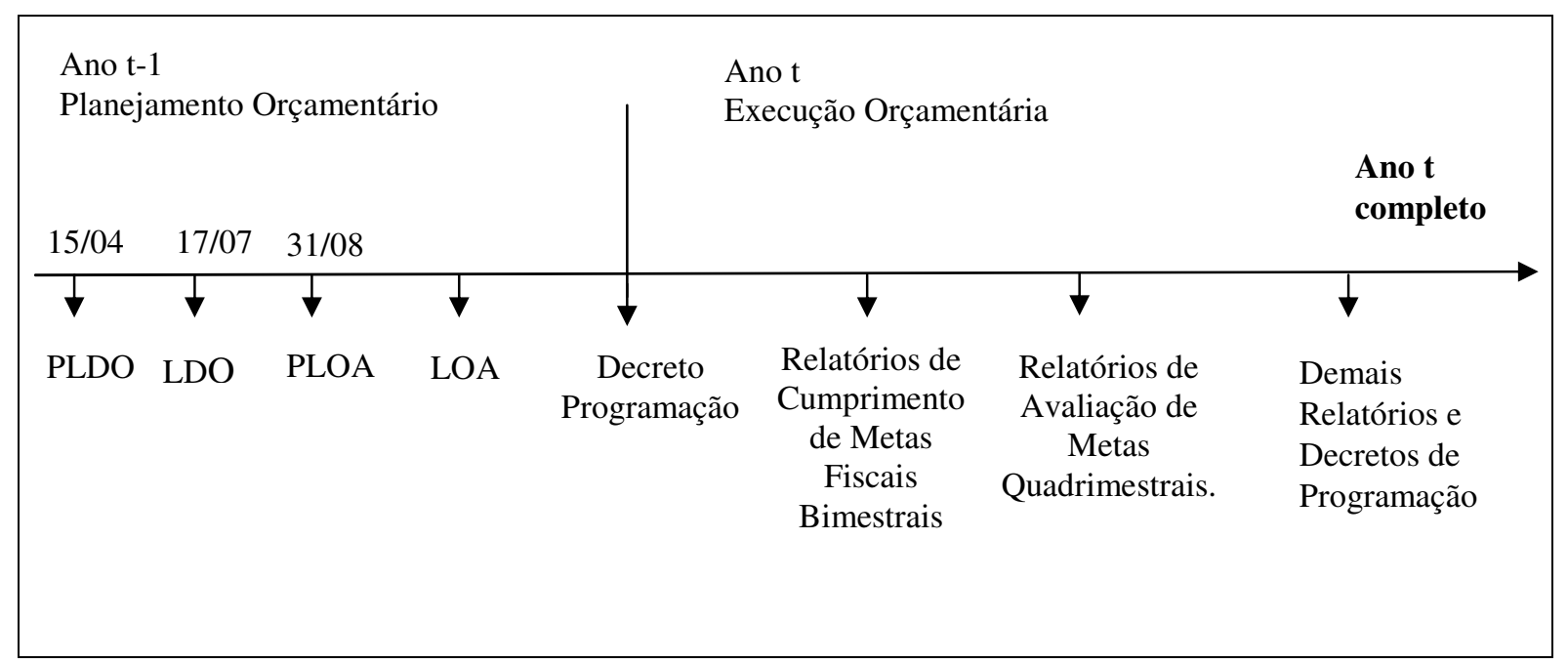

\section{Ilustração 1 - Documentos Oficiais do Processo Orçamentário Utilizadas na Construção da Base de Dados \\ FONTE: Dados da pesquisa.}

Conforme vimos no Capitulo 3, o ciclo orçamentário brasileiro inicia-se com o Plano Plurianual de Investimentos. No entanto, como a PPA não apresenta previsões fiscais no formato que se enquadra no objetivo desta tese ${ }^{33}$, consideraremos o início do planejamento orçamentário a partir da LDO, incluindo a proposta encaminhada pelo Executivo ao Congresso (PLDO).

A Ilustração 1 mostra a fase de planejamento e aprovação do orçamento no ano t-1, com as datas limites para encaminhamento da proposta de lei e aprovação da LDO e encaminhamento da PLOA para apreciação do Congresso (não há obrigatoriedade para que a LOA seja aprovada antes do término do ano t-1). Ao longo da fase de planejamento, são realizadas previsões para o exercício fiscal seguinte (ano t). Cada um dos documentos desta fase traz atualizações das previsões orçamentárias e dos parâmetros macroeconômicos para o ano t, além de estimativas atualizadas das previsões para o ano t-1. ${ }^{34} \mathrm{~A}$ partir da publicação do Decreto de Programação Orçamentária e Financeira, inicia-se a fase de implementação do

\footnotetext{
${ }^{33}$ A PPA estabelece um cenário fiscal de referência com previsões para o superávit primário, para a dívida líquida e bruta do setor público e para o resultado nominal. Além disso, apresenta um cenário macroeconômico com previsões para as principais variáveis econômicas que também afetam o resultado físcal: PIB, IPCA, IGPDI, taxa Over-Selic, taxa de câmbio e massa salarial. Porém, as previsões orçamentárias tem como objetivo principal a identificação das fontes de financiamento destinado aos projetos elencados na PPA e não os resultados fiscais. Outra razão para a não utilização das previsões contidas no PPA é o pequeno número de observações dados por estes documentos, já que os mesmos são realizados a cada quatro anos.

${ }^{34}$ A LDO contem previsões para $\mathrm{t}, \mathrm{t}+1$ e $\mathrm{t}+2$, além de estimativas para o ano $\mathrm{t}-1$ e $\mathrm{t}-2$.
} 
orçamento. Quando ocorrem mudanças nos parâmetros macroeconômicos, as projeções de receitas e despesas primárias são atualizadas e a Programação Financeira e os Cronogramas de desembolso são revistos com a publicação de novos Decretos, pelos quais o Governo decide por contingenciar ou expandir a liberação de recursos de acordo com o que se espera ocorrer com a arrecadação.

Ao final de cada bimestre e, também, de cada quadrimestre, o cumprimento das metas fiscais são avaliados e são divulgados relatórios demonstrando a arrecadação efetiva e os gastos realizados até aquele momento, as mudanças que porventura tenham ocorrido nas previsões e o que se espera para o restante do ano em termos de arrecadação e despesas. Os relatórios de execução orçamentária emitidos pelo Tesouro Nacional e os relatórios de arrecadação emitidos pela SRF complementam esses documentos da fase de implementação do orçamento. Uma descrição mais detalhada destes documentos é apresentada no Apêndice I ao final desta pesquisa.

Dos documentos fiscais, utilizamos os valores previstos e realizados das seguintes variáveis: Receita Primária Total e Despesa Primária Total; Taxa de Crescimento Real do PIB; taxa Over-Selic média anual, taxa de câmbio R\$/US\$ média anual; taxas médias anuais do IPCA e do IGP-DI; variação anual da massa salarial; preço médio em dólar do barril de Petróleo do tipo Brent.

Uma importante questão deve ser mencionada. A principal dificuldade encontrada na realização deste trabalho diz respeito à disponibilidade de dados em tempo real existentes para a política fiscal brasileira. A análise da política fiscal com dados em tempo real é relativamente nova na literatura e principalmente voltada aos países da União Europeia e OECD, em função da maior existência desse tipo de dado nessas economias. Ainda assim, os estudos presentes na literatura sobre o assunto, com raras exceções, analisam um painel de países, ao invés de um único país, para obter uma oferta maior de dados anuais, haja vista que as previsões das variáveis macroeconômicas são feitas em termos anuais.

No caso brasileiro, as previsões fiscais elaboradas pelo Governo também são previsões anuais. A taxa de crescimento, a taxa de inflação, de juros, o superávit primário, a dívida pública, entre outras variáveis previstas na LDO, na LOA ou em qualquer relatório físcal são previstas em termos anuais. Porém, a dificuldade em utilizar esses dados anuais é a curta série 
de tempo entre a aprovação da Lei de Responsabilidade Fiscal, que marca o início do planejamento orçamentário nos moldes em que interessa a esse estudo, e os dias de hoje. Em função disso, os dados utilizados nesse capítulo tiveram que ser adaptados para se tornarem úteis ao propósito desta tese. Dessa maneira, construímos duas bases de dados diferentes, sendo que a primeira delas contem observações anuais, totalizando 14 observações para cada variável para os anos de 2002 a 2015. Tendo em vista o pequeno número de observações, esta base de dados foi utilizada principalmente para a análise gráfica e descritiva que será apresentada no capítulo atual. A segunda base de dados contem 84 observações bimestrais, também para o período de 2002 a 2015 e será utilizada para as estimações econométricas.

Em relação à base de dados com observações anuais, não houve grandes dificuldades envolvidas na sua construção. Para a construção da variável "desvio de execução" são necessárias as previsões e os valores realizados em tempo real das variáveis que se pretende analisar. $\mathrm{O}$ valor realizado adotado corresponde à primeira estimativa disponível das variáveis analisadas após o final do exercício fiscal. Em outras palavras, trata-se do valor em tempo real das variáveis. Por exemplo, o valor realizado do PIB em tempo real de um ano X qualquer é a estimativa do PIB conhecida no início do ano $\mathrm{X}+1$, isto é, é a estimativa da taxa de crescimento do PIB conhecida pelo Governo imediatamente após o fim do exercício fiscal, sem revisões.

Os valores anuais previstos das variáveis foram retirados da LDO, da PLOA, da LOA e do Decreto de Programação. Como fica evidente por meio da Ilustração 1, há um intervalo de tempo entre a previsão e a observação do valor realizado da variável ao final do exercício fiscal. No caso das previsões contidas na LDO, por exemplo, esse intervalo de tempo é de aproximadamente um ano e meio, haja vista que a LDO precisa ser aprovada até 17/07 do ano t-1 e contem previsões para o ano t. Juntando esses dados com os valores realizados, pudemos obter 4 séries anuais de desvios de execução para cada variável ${ }^{35}$ : desvios em relação às previsões da LDO, desvios em relação às previsões da PLOA e desvios em relação às previsões da LOA e do Decreto de Programação. ${ }^{36}$

\footnotetext{
${ }^{35} \mathrm{Nem}$ todas as variáveis apresentam previsões divulgadas para todos os anos e em todos os documentos. É o caso, por exemplo, da massa salarial e do preço do petróleo, cujas informações começaram a constar dos documentos citados, respectivamente, a partir de 2004 e de 2005. Por outro lado, para algumas variáveis é possível calcular os desvios de previsão a partir das previsões contidas nas LDO's dos anos t-2 e t-3, como no caso da Receita Primária Total.

${ }^{36}$ A LDO de 2003 não trás previsões para a Receita e para a Despesa, apenas previsões para o superávit primário. Essa informação ficou ausente na base de dados.
} 
Para a construção da base de dados com observações bimestrais, a principal dificuldade envolvida foi justamente conciliar as previsões anuais com a necessidade de um número razoável de observações para realizar o estudo econométrico. Para resolver esse problema foram testadas duas alternativas possíveis.

A primeira alternativa avaliada envolveu o uso das previsões de arrecadação constantes dos anexos dos decretos de programação financeira. Esses decretos são publicados em até 30 dias após a sanção presidencial da Lei Orçamentária e apresentam a programação financeira e o cronograma mensal de desembolso por órgão ou unidade orçamentária. Além disso, as previsões de arrecadação das receitas primárias são desdobradas em previsões de arrecadação bimestral e também em previsões quadrimestrais. Em outras palavras, no início do ano fiscal, o total de arrecadação previsto para todo o ano t é distribuído entre os 6 bimestres do ano, de modo que em cada um dos bimestres deve-se arrecadar uma fração da receita total prevista. A partir das arrecadações previstas para cada bimestre, há também uma previsão para a arrecadação acumulada em cada quadrimestre do ano. Para obter um número maior de observações, utilizamos as previsões de arrecadação desdobradas em "metas" bimestrais para construir a série de receita prevista. Os valores efetivamente arrecadados em cada bimestre são confrontados com suas respectivas metas bimestrais para gerar a série de desvio de execução da receita.

Diversas dificuldades emergem dessa opção. Uma delas decorre do fato que apenas a arrecadação apresenta previsões bimestrais. Para a despesa primária somente há previsões quadrimestrais, o que dificultaria o usa dessas duas variáveis conjuntamente. Outra dificuldade diz respeito aos parâmetros macroeconômicos. Embora haja revisões frequentes das previsões dos parâmetros macroeconômicos, os mesmos são previstos em termos de variações e/ou valores médios anuais, ao passo que as previsões de arrecadação são apresentadas em termos de arrecadação acumulada no bimestre. Uma terceira dificuldade também decorre da relação entre previsão de receita e previsão das variáveis macroeconômicas. Enquanto as previsões retiradas do Decreto de Programação são realizadas no início do ano fiscal t para os 6 bimestres do ano t, as previsões macroeconômicas são retiradas dos Relatórios Bimestrais de Cumprimento de Metas Fiscais e, portanto, são atualizadas ao longo de todo o ano t. Dessa forma, as revisões das previsões dos parâmetros macroeconômicos ao longo do ano recebe a influência de informações que não estavam 
disponíveis quando as previsões de arrecadação constantes do Decreto de Programação foram realizadas.

A segunda alternativa disponível para a construção da base de dados bimestrais foi a opção escolhida. As previsões anuais das variáveis, tanto da receita primária quanto da despesa e dos parâmetros macroeconômicos foram obtidas a partir dos relatórios fiscais publicados ao longo de todo o ano. Desse modo, para o primeiro bimestre do ano, utilizamos as previsões que embasaram o Decreto de Programação. Esse Decreto costuma ser publicado no início de cada exercício fiscal e, portanto, podemos assumir que as previsões de arrecadação anual nele contida e a grade de parâmetros macroeconômicos que o embasaram referem-se às previsões disponíveis ao governo naquele período. Para os demais bimestres do ano, utilizamos principalmente as previsões de arrecadação contidas nos Relatórios Bimestrais de Avaliação de Receitas e Despesas e também nos Relatórios Quadrimestrais de Cumprimento de Metas Fiscais.

A forma escolhida para captação dos dados em tempo real permite corrigir os problemas apresentados anteriormente, vinculados ao uso das previsões bimestrais do Decreto de Programação. No entanto, há outros problemas associados à alternativa escolhida. O principal desses problemas diz respeito ao cálculo dos desvios de execução. As previsões tendem a se aproximar do valor observado da variável conforme nos caminhamos para o final do ano e isso faz com que os desvios de execução sejam sempre maiores nos primeiros bimestres do ano e menores no último bimestre para todas as variáveis para as quais o desvio é calculado.

Outro problema é que as informações sobre as revisões nos parâmetros macroeconômicos não estão disponíveis sempre com a mesma frequência no tempo e as datas de publicação dos Decretos de Programação não coincidem com as datas em que a grade de parâmetros macroeconômicos é elaborada. Por exemplo, no ano de 2005, o Relatório de Avaliação das Metas relativo ao terceiro quadrimestre do ano informa que o Decreto n. 5.379 de 25 de fevereiro de 2005, que dispõe sobre a programação orçamentária e financeira, foi baseado na grade de parâmetros elaborada em 11 de janeiro de 2005. O segundo decreto de programação daquele ano, que alterou os valores constantes do primeiro decreto, foi o Decreto n. 5.463 elaborado a partir das previsões macroeconômicas de 13 de junho. Ou seja, os Relatórios de Avaliação de 2005 não trazem informações sobre os parâmetros macroeconômicos que estavam pautando as previsões orçamentárias nesse intervalo de 5 meses entre um decreto e 
outro. Situações como esta se repetiram em diversas outras ocasiões como, por exemplo, em 2006, em que não há informações a respeito das previsões relativas ao segundo bimestre do ano. Em casos como estes, quando não foi possível encontrar essa informação em outras fontes oficiais (por exemplo, em documentos da Receita Federal, Notas Técnicas do Congresso, outros documentos da Secretaria de Política Econômica ou do Tesouro Nacional, etc. ${ }^{37}$ ) as informações utilizadas foram aquelas disponíveis para o bimestre imediatamente anterior, partindo-se do princípio de que as previsões não haviam sido alteradas de um bimestre a outro.

Houve anos nos quais a LOA foi aprovada tardiamente, como em 2008 em que a aprovação ocorreu no mês de março e o Decreto de Programação só foi publicado ao final do mês de abril. Neste caso específico, utilizamos as expectativas de 11 de fevereiro, que embasaram a decisão do Congresso sobre o Orçamento, como sendo as previsões relativas ao primeiro bimestre de 2008, e os parâmetros que embasaram o Decreto de Programação como sendo relativos ao segundo bimestre. Situação semelhante ocorreu em 2013, ano no qual a LOA foi aprovada em 04 de abril. Neste caso, o Relatório de Avaliação do Cumprimento de Metas publicado em maio apresentou as previsões constantes da grade de parâmetros macroeconômicos elaborada em 07 de março que adotamos como sendo as previsões relativas ao segundo bimestre de 2013. Para o primeiro bimestre, as informações foram retiradas do Relatório Final da CMO ao Projeto de Lei Orçamentária.

Além das dificuldades citadas, alguns outros problemas de menor magnitude também exigiram adaptações. ${ }^{38}$ Apesar das questões apontadas, os documentos fiscais também se aprimoraram ao longo dos anos, conforme o número de informações disponibilizadas aumentou e o padrão de apresentação foi melhorando, permitindo estabelecer comparações entre os anos. ${ }^{39}$

\footnotetext{
37 Além dos documentos listados, em alguns casos foi necessário recorrer aos relatórios de inflação do Banco Central, ao Boletim Focus, aos Boletins do Banco Central e aos Balanços Gerais da União a fim de complementar informações ausentes nos documentos fiscais.

${ }^{38}$ Nos anos iniciais da amostra, a Lei de Responsabilidade Fiscal ainda era bastante recente e os relatórios fiscais eram muito simplificados, deixando a desejar na oferta de informações. Adicionalmente, os relatórios bimestrais dos anos de 2002 e 2003 não estão disponíveis para consulta online e não fica claro se eles foram produzidos para aqueles anos. Para 2002 e 2003 somente foi possível contar com os Relatórios de Cumprimento de Metas quadrimestrais. Outra questão é que, embora as previsões fiscais utilizem os valores médios esperados das variáveis de Inflação, Selic e Câmbio, para o ano de 2002 só há previsões da variação acumulada no ano e não da variação média anual.

${ }^{39}$ Um exemplo de melhoria foi que a partir de 2005 os relatórios passaram a divulgar as datas de divulgação dos parâmetros macroeconômicos que foram utilizados para embasar os decretos de programação.
} 
Enfim, os problemas citados expõem a dificuldade encontrada na construção da base de dados utilizada nesta pesquisa. Buscamos, na medida do possível, minimizar essas dificuldades, haja vista que não há no Brasil uma base de dados oficial que nos forneça as informações fiscais em tempo real. O mais próximo que temos disso é a série estatística de expectativas de mercado disponibilizadas pelo Banco Central em que são apresentadas as expectativas para os resultados fiscais nos conceitos primário e nominal e para a dívida líquida do setor público, além de expectativas para outras variáveis macroeconômicas. Porém, essas estatísticas contem apenas as previsões do mercado e não as previsões oficiais do Governo. Recentemente, a Secretaria de Política Econômica do Ministério da Fazenda lançou o Prisma Fiscal com o objetivo de disponibilizar dados das expectativas de mercado para as variáveis fiscais brasileiras. A iniciativa é recente e a base de dados é curta, mas também só conta com expectativas dos agentes de mercado. Iniciativas desse tipo precisam ocorrer com as expectativas oficiais que fundamentam as decisões do governo.

Como se depreende do relato precedente, as análises realizadas nesta tese possuem limitações inerentes às falhas encontradas na construção da base de dados. Dessa forma, os resultados e conclusões apresentados estão condicionados por essas limitações e devem ser interpretados com as devidas ressalvas.

\section{Os desvios de execução orçamentários}

O Gráfico 1 apresenta a receita primária total anual prevista na Lei Orçamentária e a receita efetivamente realizada. ${ }^{40}$ Podemos identificar dois momentos bastante distintos ao longo do período sob análise, sendo o primeiro momento o que vai de 2002 até 2007 e o segundo o que se estende de 2008 até 2015 . No primeiro momento, a curva de receitas realizadas ajusta-se à curva de receitas previstas, indicando um planejamento orçamentário mais preciso. No segundo momento, há uma reversão da tendência de ajuste observada no período anterior. A partir de 2008, os valores realizados passaram a se distanciar com maior frequência e com

\footnotetext{
${ }^{40}$ Receita primária total inclui as receitas administradas pela Receita Federal do Brasil (RFB), líquida de restituições e incentivos fiscais, mais as receitas não administradas pela RFB e a arrecadação líquida da Previdência Social.
} 
mais intensidade dos valores previstos, sendo que em todos os anos a partir de 2012 as previsões contidas na LOA passaram a superestimar a arrecadação efetiva.

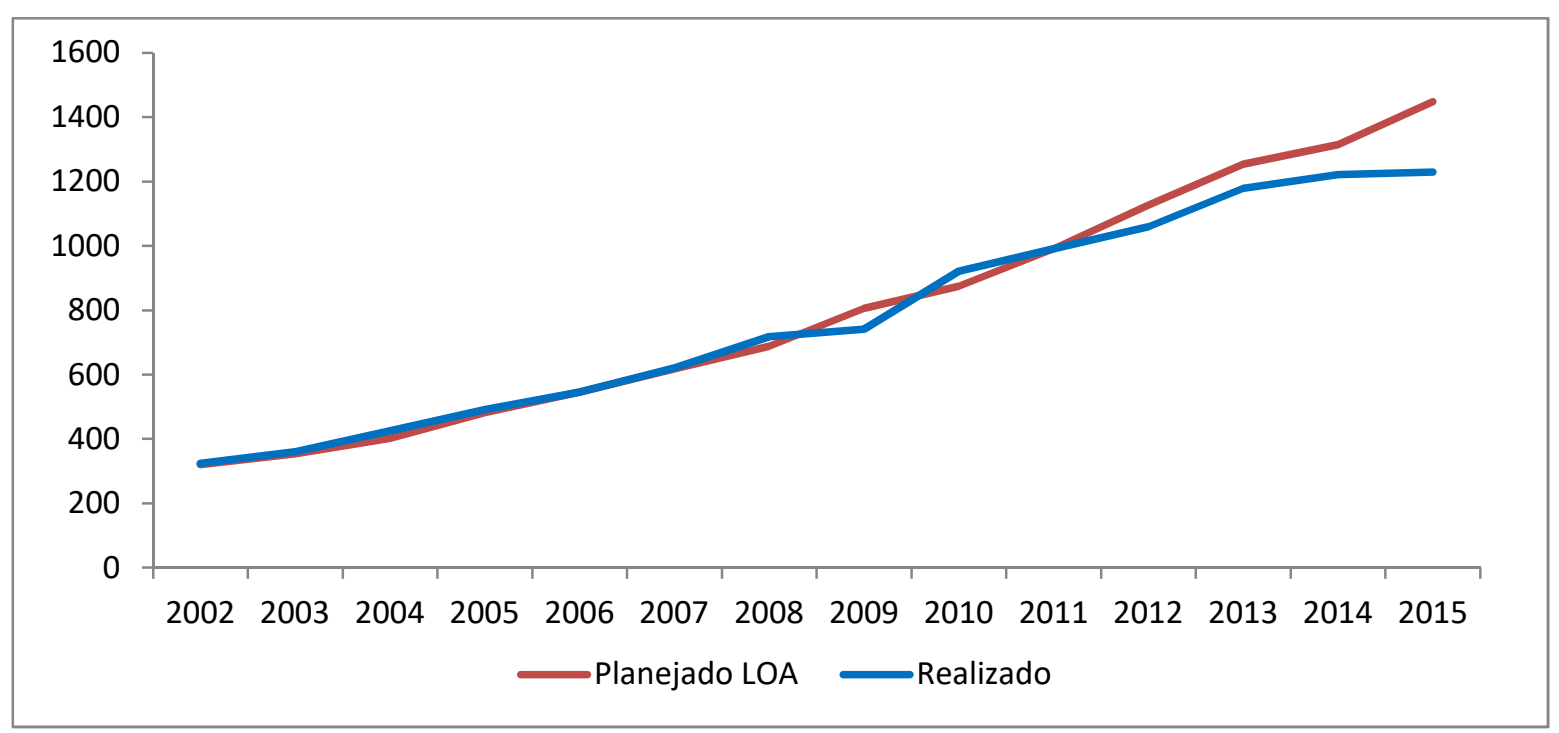

Gráfico 1 - Receita Primária Total do Governo Central, valores previstos e realizados - R\$ bilhões FONTE: Dados da Pesquisa.

O Gráfico 2 a seguir apresenta os desvios de execução da receita primária anual. Trata-se da diferença entre as duas curvas constantes no Gráfico 1, ou seja, a diferença entre a receita primária total prevista na LOA e o valor efetivamente realizado. Podemos notar que até o ano de 2008, os desvios foram positivos e próximos de zero em termos absolutos, indicando que previsão orçamentária foi mais precisa. A partir de 2008 a tendência se inverteu, com prevalência de desvios de maior magnitude e, a partir de 2012 temos a indicação de erros de previsão persistentes e crescentes, sugerindo uma deterioração na previsão fiscal, haja vista que os desvios cresceram ano após ano, sem que os desvios observados em um período servissem de aprendizado para evitar ou diminuir os desvios do período seguinte. 




Gráfico 2 - Desvio de Execução da Receita Primária Total do Governo Central (LOA) - R\$ bilhões FONTE: Dados da Pesquisa.

Os Gráficos 1 e 2 apresentaram os valores previstos e os desvio de execução da receita em relação às previsões contidas na LOA. No entanto, os desvios de execução variam de acordo com a fase do processo orçamentário. Como mostramos no capítulo 3 desta tese, a Lei de Diretrizes Orçamentárias define as metas e prioridades que guiam a elaboração e aprovação do Orçamento Anual. Ao apresentar as metas fiscais, a LDO apresenta estimativas da receita e da despesa primárias para os três exercícios fiscais subsequentes, isto é, a LDO elaborada no ano t-1 para guiar o orçamento do ano t, contem previsões do resultado fiscal tanto para o ano $\mathrm{t}$ quanto para os anos $\mathrm{t}+1$ e $\mathrm{t}+2$. Adicionalmente, a LDO apresenta as estimativas mais recentes (nowcasts) ${ }^{41}$ para os anos t-2 e t-3, além de atualizar as previsões para o ano t-1.

O Gráfico 3 a seguir, apresenta as previsões de arrecadação para os anos de 2002 a 2015 contidas nas LDO's dos anos t, t-1 e t-2 e as comparam com os valores efetivamente realizados. Para cada ano, temos a estimativa constante na LDO daquele ano (ano t, previsto no ano t-1) e as estimativas constantes nas LDO's dos dois anos anteriores (t-2 e t-3). A comparação dos valores previstos na LDO com os valores realizados demonstra que a previsão é ainda menos precisa quanto mais longo for o horizonte de previsão. Essas conclusões são reforçadas pelo Gráfico 4, em que são apresentados os desvios de execução da receita calculados como a diferença entre a receita realizada no ano t e as previsões contidas nas LDO's aprovadas em t-1, t-2 e t-3.

\footnotetext{
${ }^{41}$ Nowcast é um conceito da metereologia e refere-se à previsão atual. No caso da previsão econômica, refere-se à estimativa atual da variável econômica. Por exemplo, a última estimativa disponível para o PIB.
} 


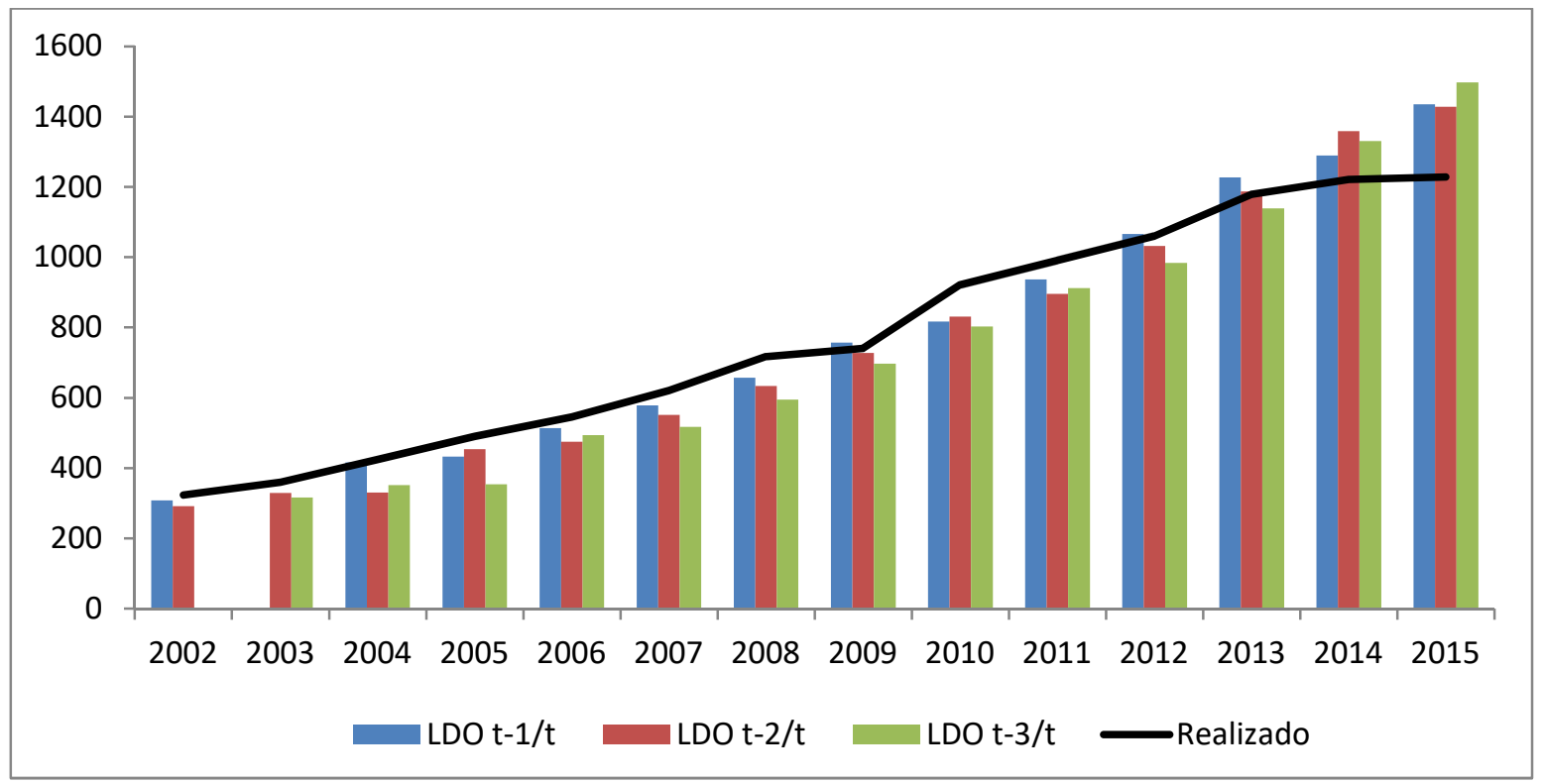

Gráfico 3 - Receita Primária Total prevista na LDO e realizada - R\$ bilhões FONTE: Dados da Pesquisa.

Obs.: Para o ano de 2002, não há a previsão realizada no ano t-3, isto é, a previsão realizada em 2000 para a receita de 2002. Para o ano de 2003, não há o valor da receita primária estimada em 2002 para a LDO 2003. Isso ocorre porque no Anexo de Metas Fiscais de 2003 consta apenas a meta de superávit primário prevista, mas não os valores absolutos da arrecadação prevista.

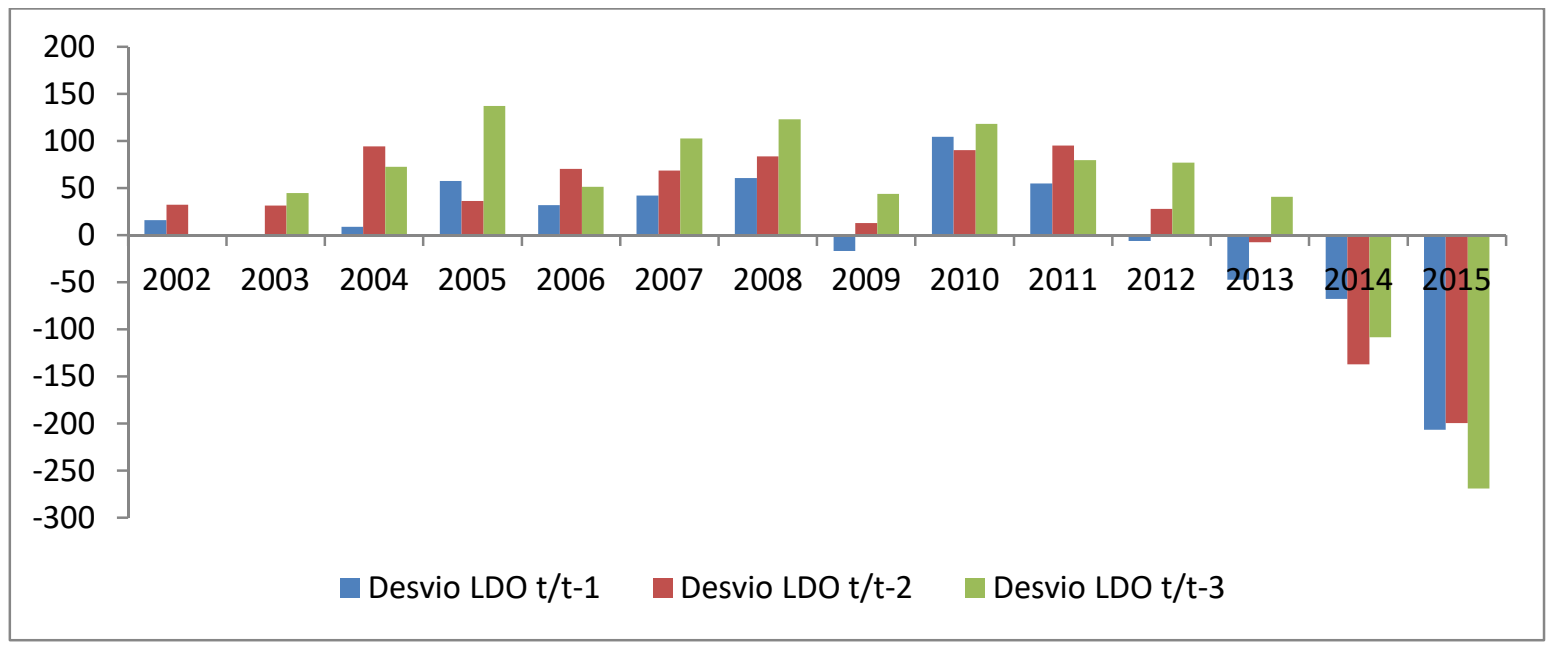

Gráfico 4 - Desvio Execução da Receita Primária Total em relação a LDO - R\$ bilhões FONTE: Dados da Pesquisa.

Os Gráficos 3 e 4 indicam que os desvios de execução da receita são maiores quanto maior o horizonte temporal de previsão. Ou seja, quanto maior a distância entre a data em que a previsão é realizada e a data para a qual se realiza a previsão, maior o desvio. Os referidos gráficos mostram também que o desvio de execução da receita é predominantemente positivo, 
indicando que as previsões contidas na LDO são subestimadas. As exceções são os anos de 2013 a 2015, nos quais as previsões não anteciparam a queda ocorrida na arrecadação.

Os Anexos de Metas Fiscais enfatizam que as previsões realizadas na LDO para os anos $t+2$ e t+3 são consideradas apenas indicativas. Mas, na verdade, podemos inferir que essas previsões cumprem somente uma exigência legal, pois não há nenhum compromisso com a realização dos valores estimados para além do ano $t+1$.

Podemos comparar os desvios de execução calculados a partir das previsões realizadas em cada fase do processo orçamentário. Em relação à fase de planejamento do orçamento, podemos comparar os desvios entre a receita realizada e as previsões contidas, respectivamente, na LDO publicada em t-1, na Proposta de Orçamento, na Lei Orçamentária e na Programação Orçamentária e Financeira emitida logo após a sanção da LOA. O Gráfico (5) a seguir apresenta esses dados.

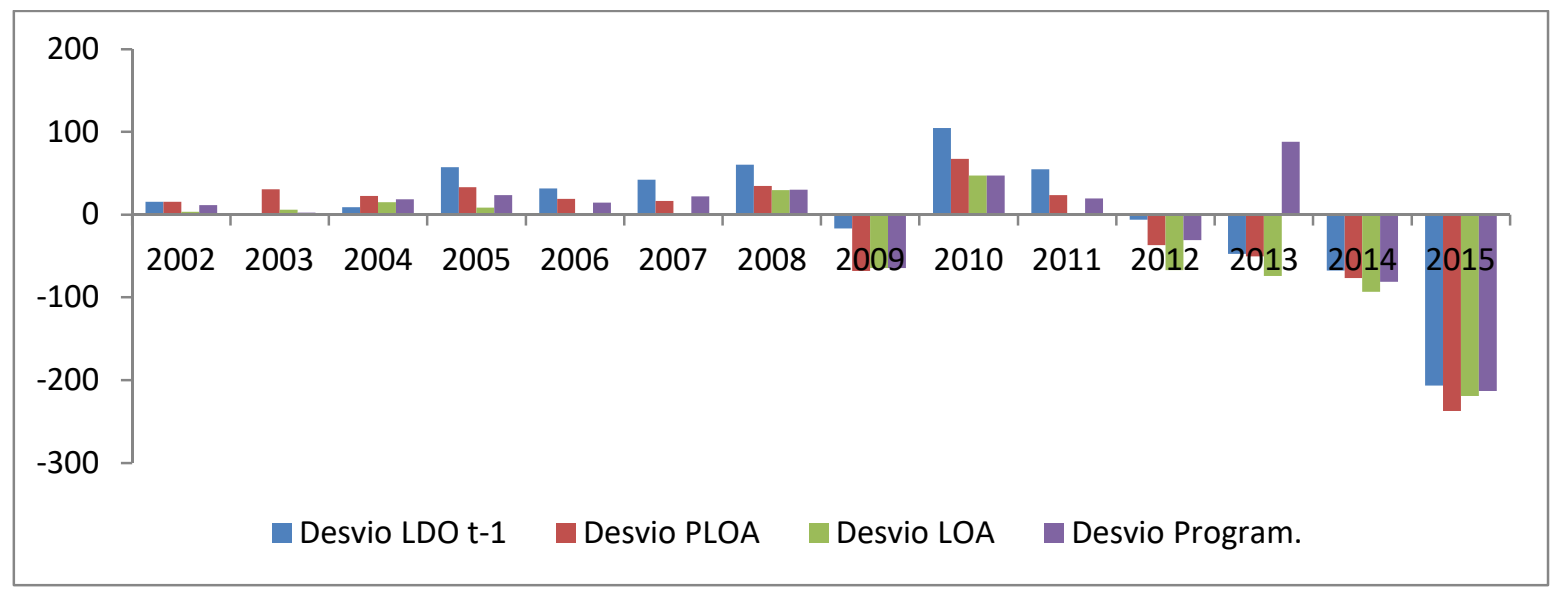

Gráfico 5 - Desvio Execução da Receita Primária Total (LDO, PLOA, LOA, Programação) - R\$ bilhões FONTE: Dados da Pesquisa.

O Gráfico 5 mostra que em 2002, de 2005 a 2008 e em 2010 e 2011 os desvios foram maiores para as previsões contidas na LDO do que nos demais documentos. Além disso, até 2011 os desvios foram predominantemente positivos indicando que a receita realizada superou as previsões (exceto no ano de 2009, no qual a crise que atingiu a economia não foi prevista durante o planejamento orçamentário). A partir de 2012, os indícios de uma deterioração na previsão fiscal aparecem em todas as etapas do planejamento. Adicionalmente, os desvios em relação às previsões contidas na LOA destacaram-se na comparação com as demais fases do 
processo de planejamento orçamentário. Isto parece contradizer a afirmação anterior de que as previsões tendem a se desviar mais fortemente dos valores observados das variáveis quanto mais longo for o horizonte de previsão, uma vez que os desvios em relação às estimativas contidas na Programação Financeira são maiores que os desvios relacionados às estimativas da LOA. Uma explicação para isso advém da relação entre Executivo e Congresso na aprovação da Lei Orçamentária, assunto que será abordado mais à frente em uma subseção específica.

No que se refere aos desvios de execução da despesa, o Gráfico (6) apresenta as previsões realizadas na LDO preparada em t-1, do Projeto de Lei, da LOA e do Decreto de Programação Financeira, comparando-as com os valores realizados. Podemos observar que as previsões realizadas na LDO são sempre superestimadas, ficando acima das demais previsões e do valor realizado. É possível notar também que as previsões contidas na LOA superam as previsões contidas no projeto de lei que o Executivo encaminha ao Congresso. Isto é, assim como faz com as previsões de arrecadação, o Congresso costuma aprovar o orçamento com as despesas majoradas em relação à proposta original. Posteriormente, no cronograma de liberação financeira, o Governo reduz novamente as expectativas em relação à arrecadação, reduzindo também as despesas previstas.

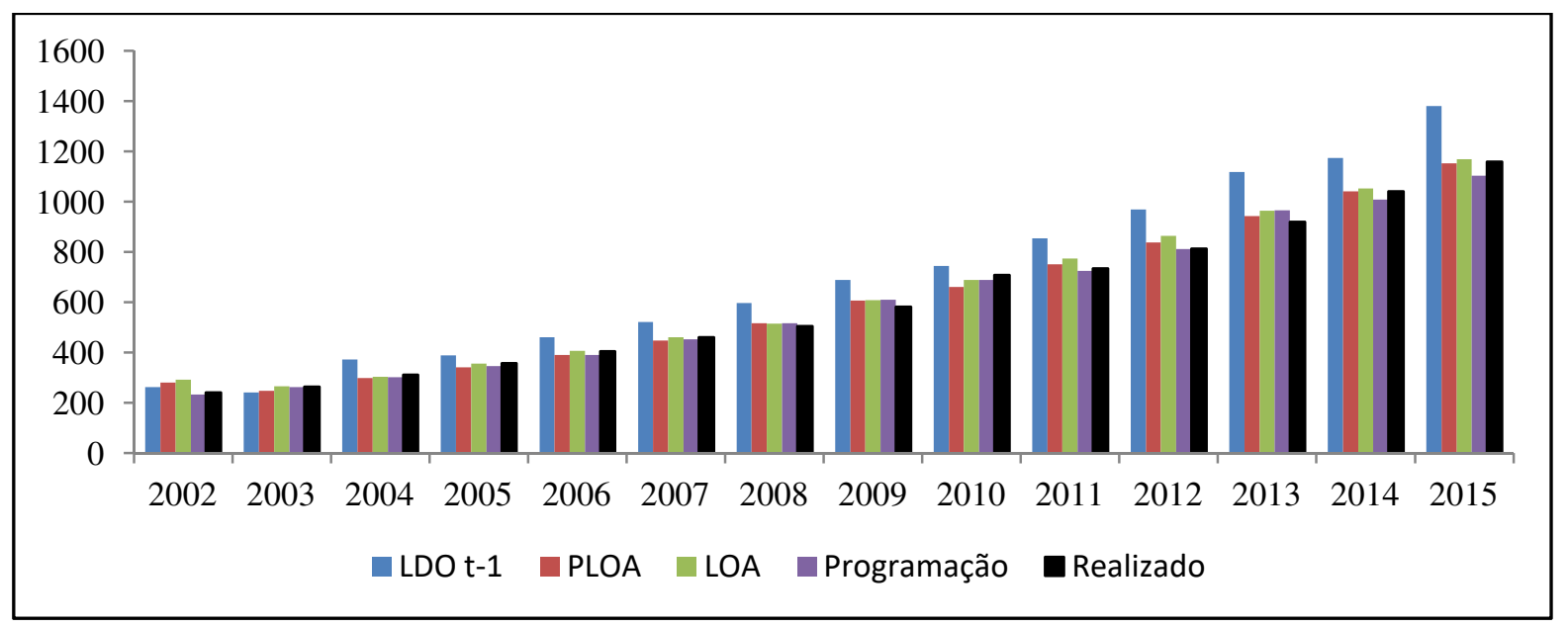

Gráfico 6 - Despesa Primária Total do Governo Central, valores previstos e realizados - R\$ bilhões FONTE: Dados da Pesquisa.

Se olharmos especificamente para os desvios de execução da despesa, podemos perceber que, assim como vimos em relação aos desvios de execução da receita, há dois momentos distintos no tempo. Excluindo-se o ano de 2002 que foi um ano atípico em função da crise política pela qual a economia brasileira passou, podemos dividir os demais anos em dois subperíodos: um 
subperíodo de 2003 a 2008 e outro de 2009 em diante. Até 2008 os desvios de execução da despesa são menores e, predominantemente, positivos, indicando que a despesa realizada superou a previsão. Além disso, os desvios em relação às previsões contidas na LOA são muito próximos de zero. A partir de 2009, os desvios se ampliam consideravelmente e se tornam predominantemente negativos. A superestimação das despesas previstas a partir de 2009 coincide com a superestimação das receitas. Como a arrecadação ficou abaixo da previsão, as despesas realizadas também foram reduzidas para que a meta de superávit fiscal fosse alcançado. Porém, no mesmo período em que houve queda nas despesas em relação à previsão, houve também elevação da rubrica Restos a Pagar, indicando o adiamento da realização das despesas e, não necessariamente, redução de gastos. No capítulo seguinte iremos discutir melhor esse assunto. É interessante observar também que a partir de 2009 os desvios em relação à LOA se elevaram, indicando menor precisão nas previsões contidas na Lei Orçamentária.

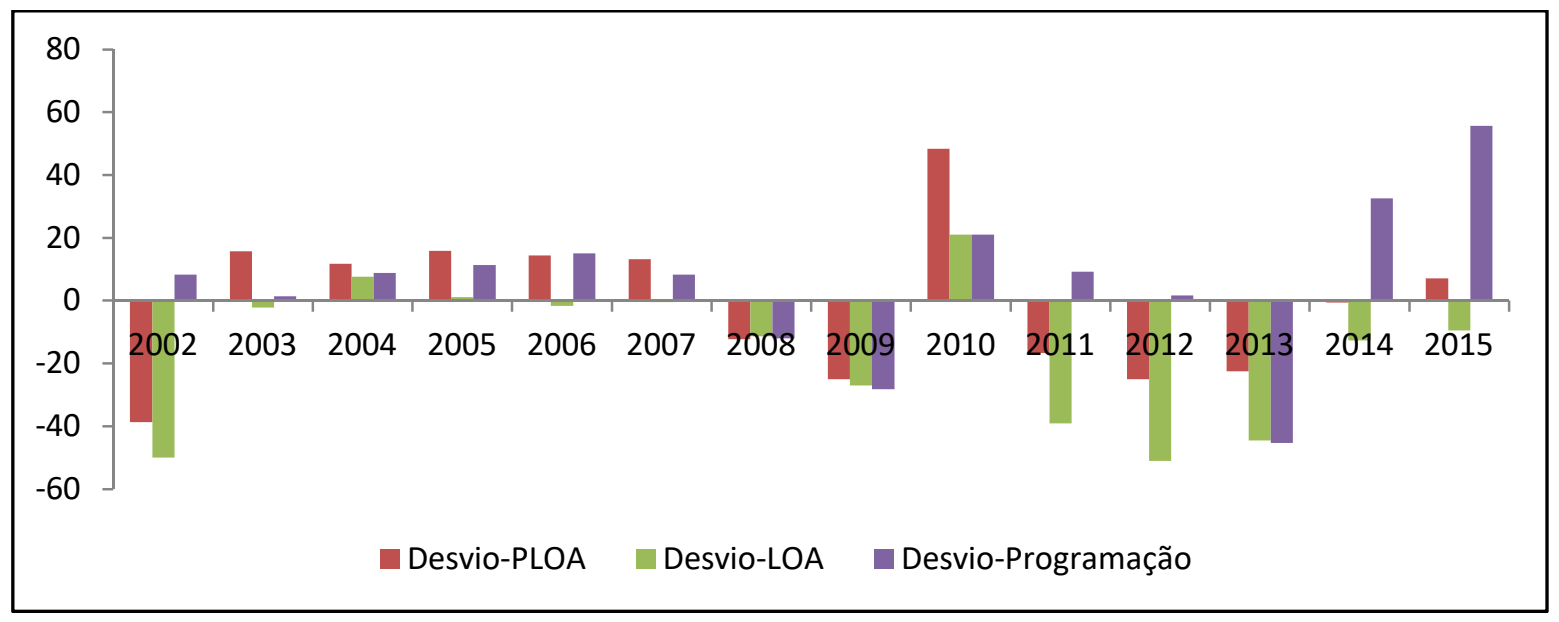

Gráfico 7 - Desvio Execução da Despesa Primária Total (PLOA, LOA, Programação) - R\$ bilhões FONTE: Dados da Pesquisa.

De acordo com a literatura analisada, os desvios de execução do orçamento podem ser atribuídos, ao menos em parte, aos erros de previsão das variáveis macroeconômicas que afetam os resultados fiscais, principalmente aos Desvios de execução do PIB. O Gráfico 8 a seguir apresenta os valores previstos na LOA da taxa de crescimento real do PIB ao ano e os valores realizados. Os dados sugerem que houve um excesso de otimismo na previsão do crescimento econômico. Apenas em 4 dos 14 anos analisados, a taxa de crescimento realizada superou a taxa prevista. Nos demais anos, o PIB ficou abaixo do previsto na Lei Orçamentária. 


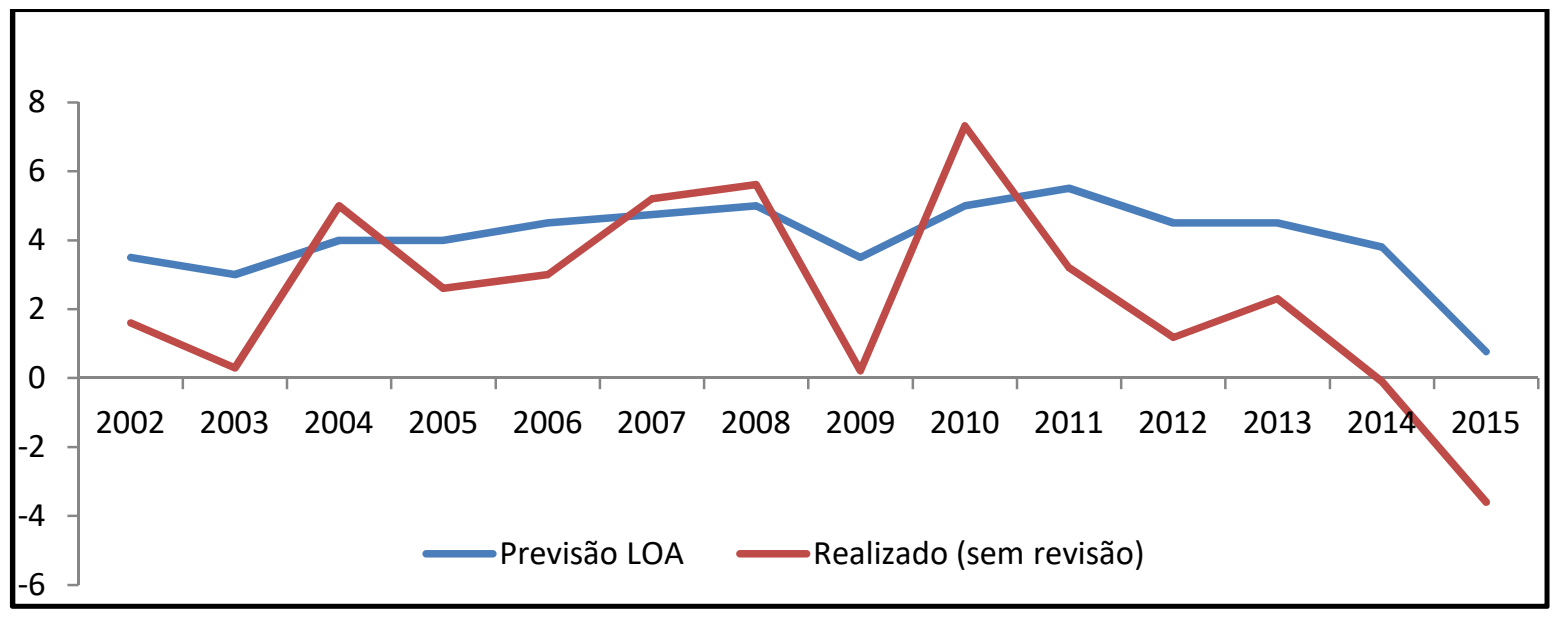

Gráfico 8 - Taxa de Crescimento Real do PIB, valores previstos e realizados* FONTE: Dados da Pesquisa.

*Os valores realizados referem-se à última estimativa disponível no ano em questão.

Somente nos anos de 2004, 2007, 2008 e 2010 o crescimento real efetivo superou as expectativas. Em todos os demais anos da pesquisa o otimismo em relação à taxa de crescimento real esperada não se realizou. Na verdade, após atingir uma taxa de $7.32 \%$ de crescimento real em 2010, a taxa de crescimento real do PIB engatou em uma trajetória decrescente que não foi acompanhada por queda nas expectativas de crescimento. Apenas no ano de 2015 é que a Lei Orçamentária foi elaborada com uma expectativa de menor taxa de crescimento do PIB. Mesmo assim, a taxa de crescimento considerada na LOA de 2015, apesar de menor que nos anos anteriores, foi bastante superior à taxa efetivamente realizada ( 0,77 de expectativa contra um crescimento real negativo de $3,8 \%$ estimado no final daquele ano).

As inferências realizadas a partir do Gráfico 8 a respeito das previsões de crescimento do PIB são reforçadas pelo Gráfico 9, a seguir, no qual as taxas reais observadas de crescimento são confrontadas com as taxas previstas na LDO (t-1), na PLOA, na LOA e na Programação Financeira. O otimismo em relação ao PIB foi mantido em todas as etapas do processo de planejamento do orçamento. Nota-se que, em diversos anos, as expectativas de crescimento foram mantidas praticamente inalteradas nas diferentes fases entre a LDO e o Decreto de Programação Financeira. As exceções mais significativas são os anos de 2009, 2014 e 2015 que foram anos de queda abrupta na atividade econômica. Nestes anos, as expectativas de crescimento declinaram seguidamente em relação às expectativas contidas na LDO, embora 
tenham ficado bastante acima dos valores efetivamente realizados. No geral, as ações do Congresso Nacional não incluíram elevações na taxa esperada de crescimento econômico para justificar elevações nas receitas e, consequentemente, elevações nas despesas previstas.

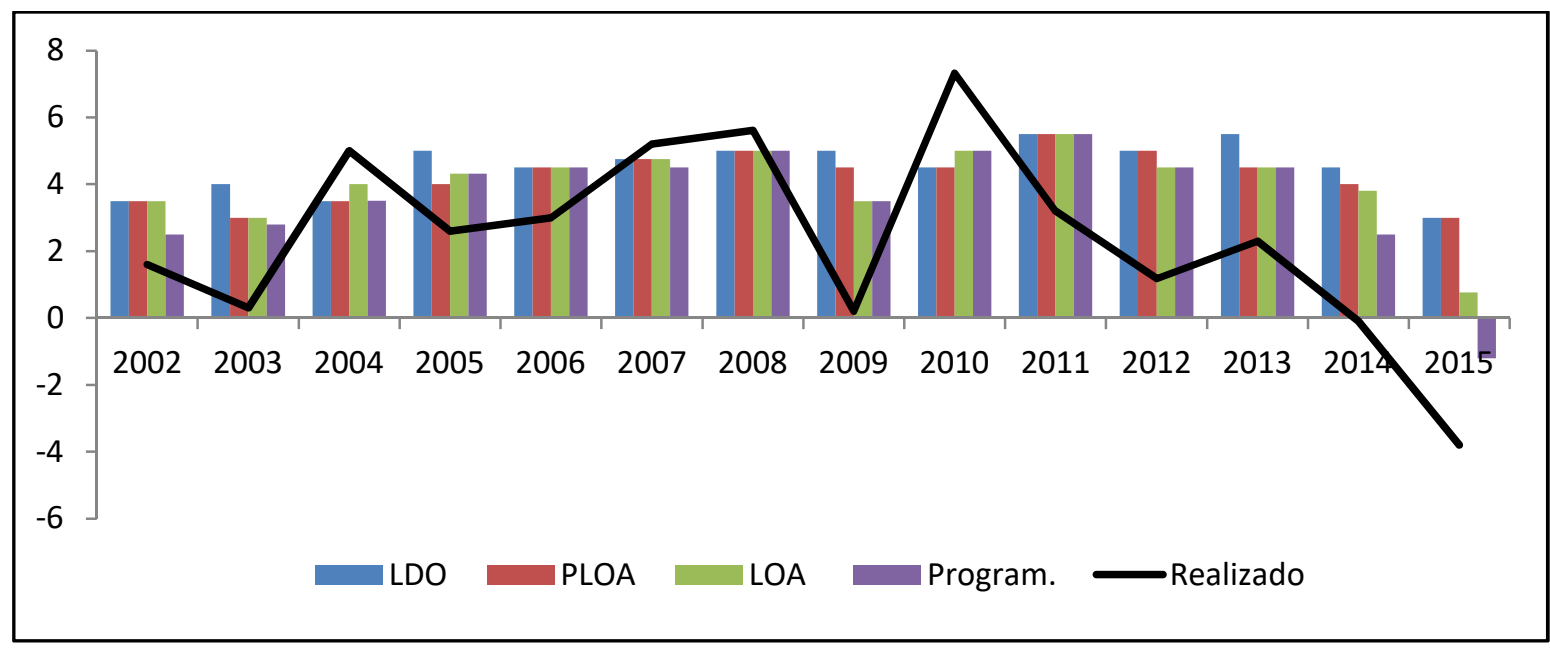

Gráfico 9 - Taxa de Crescimento Real do PIB, valores previstos e realizados* FONTE: Dados da Pesquisa.

*Os valores realizados referem-se à última estimativa disponível no ano em questão.

Além do PIB, também são utilizadas as previsões de outras variáveis macroeconômicas para estimar a arrecadação e as despesas orçamentárias. Em especial, as principais estimativas utilizadas são do IPCA, que junto ao IGP-DI constituem o índice ponderado (IEP) utilizado pela Receita Federal para estimar a arrecadação, as estimativas da taxa de câmbio, da taxa de juros Selic e da massa salarial. Os Gráficos 10 a 14 a seguir apresentam os valores previstos e realizados dos parâmetros macroeconômicos que embasam as previsões do orçamento. Para cada variável, são apresentadas as previsões constantes na LDO, na Proposta Orçamentária, na LOA e no decreto de programação e os valores efetivamente realizados.

Os Gráficos 10 e 11 referem-se às variáveis de inflação IGP-DI e IPCA, respectivamente. Podemos observar que houve uma subestimação da inflação ocorrida no período. Em relação ao IGP-DI, as taxas de inflação efetivas ficaram abaixo dos valores previstos na Lei Orçamentária apenas nos anos de 2005, 2009 e 2014. O desvio de execução foi menor nos anos de 2012 e 2013, nos quais a inflação realizada mais se aproximou da previsão de inflação (Gráfico 10). 


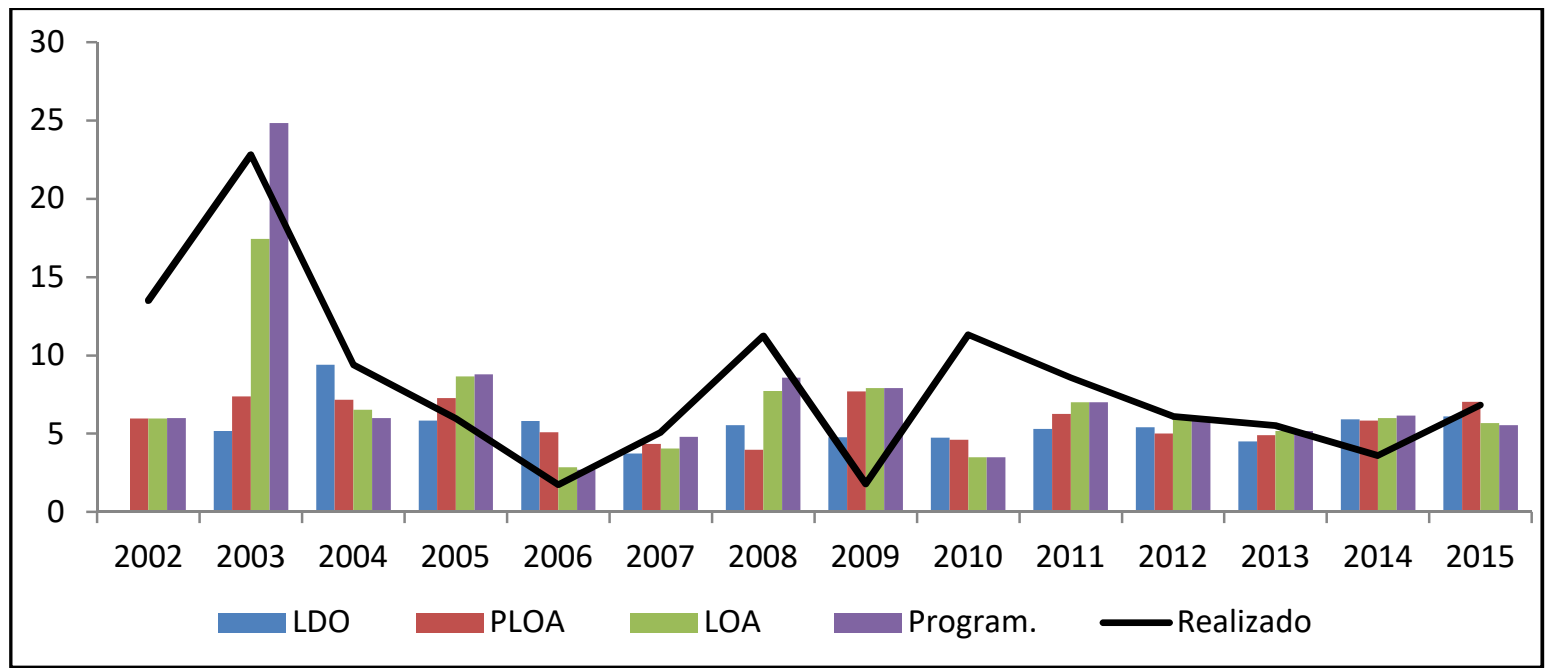

Gráfico 10 - Taxa de Inflação IGP-DI, valores previstos e realizados FONTE: Dados da Pesquisa.

Em relação à inflação medida pelo IPCA, as previsões também se mostraram otimistas em relação às taxas observadas. Se usarmos como referência apenas as previsões que fundamentaram a LOA, podemos verificar que os desvios de execução foram menores nos anos de 2005, 2009 e 2012. Em particular, embora a inflação efetiva de 2012 tenha coincidido com a previsão contida na LOA para aquele ano, o Gráfico 11 mostra que o projeto de lei orçamentário foi encaminhado ao Congresso com uma previsão menor de inflação de $4.8 \%$ ao ano. No entanto, o Congresso aprovou a Lei Orçamentária considerando uma taxa de inflação de $6 \%$ ao ano. Esta taxa prevista foi posteriormente reduzida para $4.7 \%$ por ocasião da revisão dos parâmetros macroeconômicos que embasaram o decreto de programação financeira.

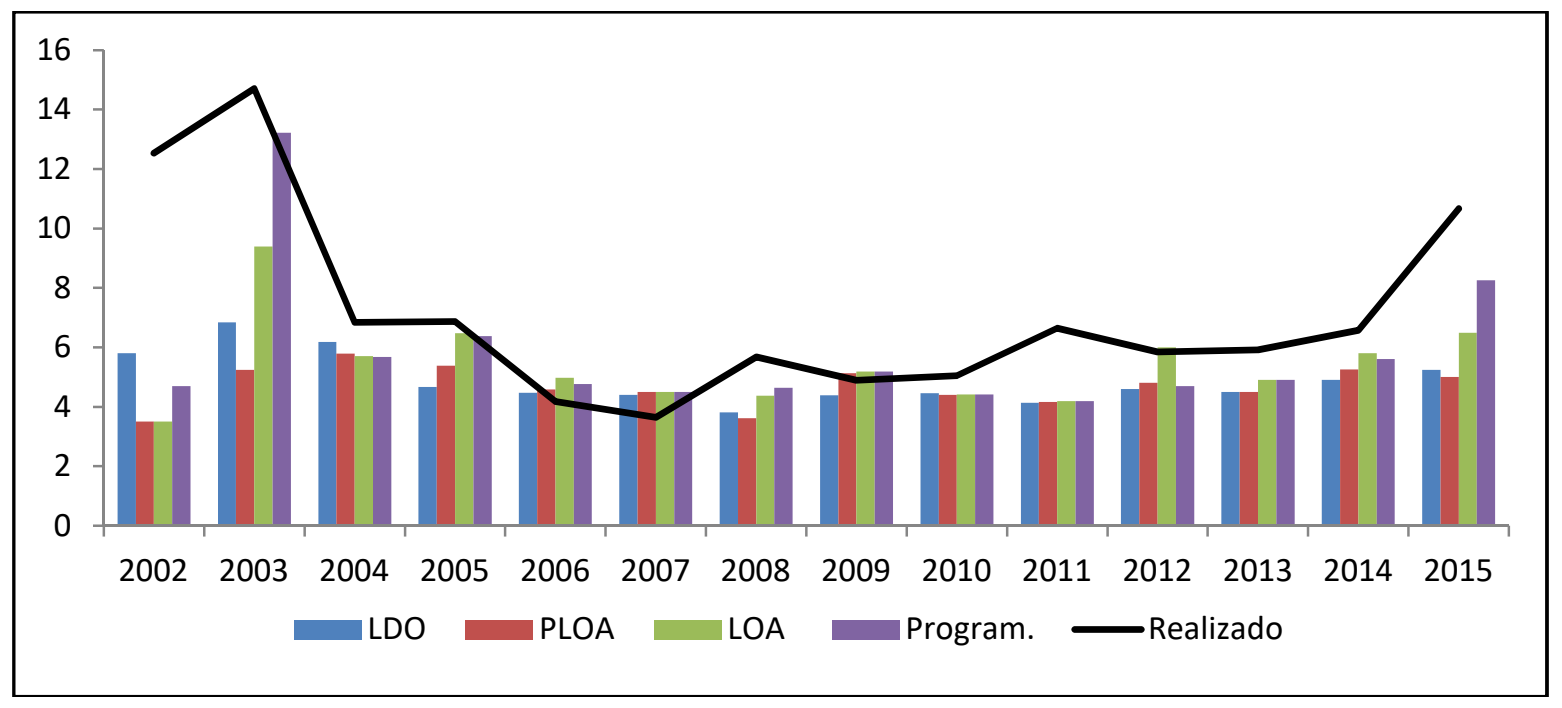

Gráfico 11 - Taxa de Inflação IPCA, valores previstos e realizados FONTE: Dados da Pesquisa. 
Em relação às previsões para a taxa de câmbio, há dois períodos claros na amostra. No primeiro período, que vai de 2003 a 2008, o câmbio observado esteve abaixo do valor previsto. Ou seja, a taxa de câmbio se apreciou mais do que o valor previsto ao longo de todo o planejamento orçamentário. O segundo período, que se inicia em 2012 e vai até o final da amostra, a trajetória da taxa de câmbio se inverteu, depreciando-se além do valor previsto (Gráfico 12).

No que diz respeito à taxa de juros Selic, em pelo menos dois terços dos anos sob análise, a taxa foi subestimada ao longo do planejamento fiscal (Gráfico 13). As exceções foram os anos de 2006 e 2007, nos quais a taxa de inflação era decrescente e ficou abaixo do centro da meta de inflação. Outras exceções foram os anos de 2009, em que foram realizadas políticas monetárias expansionistas para reverter o quadro de recessão pelo qual a economia brasileira atravessava, e o ano de 2012, em que a taxa de juros ingressou em uma trajetória decrescente ao longo do ano, como reflexo das medidas provenientes da "Nova Matriz Macroeconômica" adotada pelo governo federal.

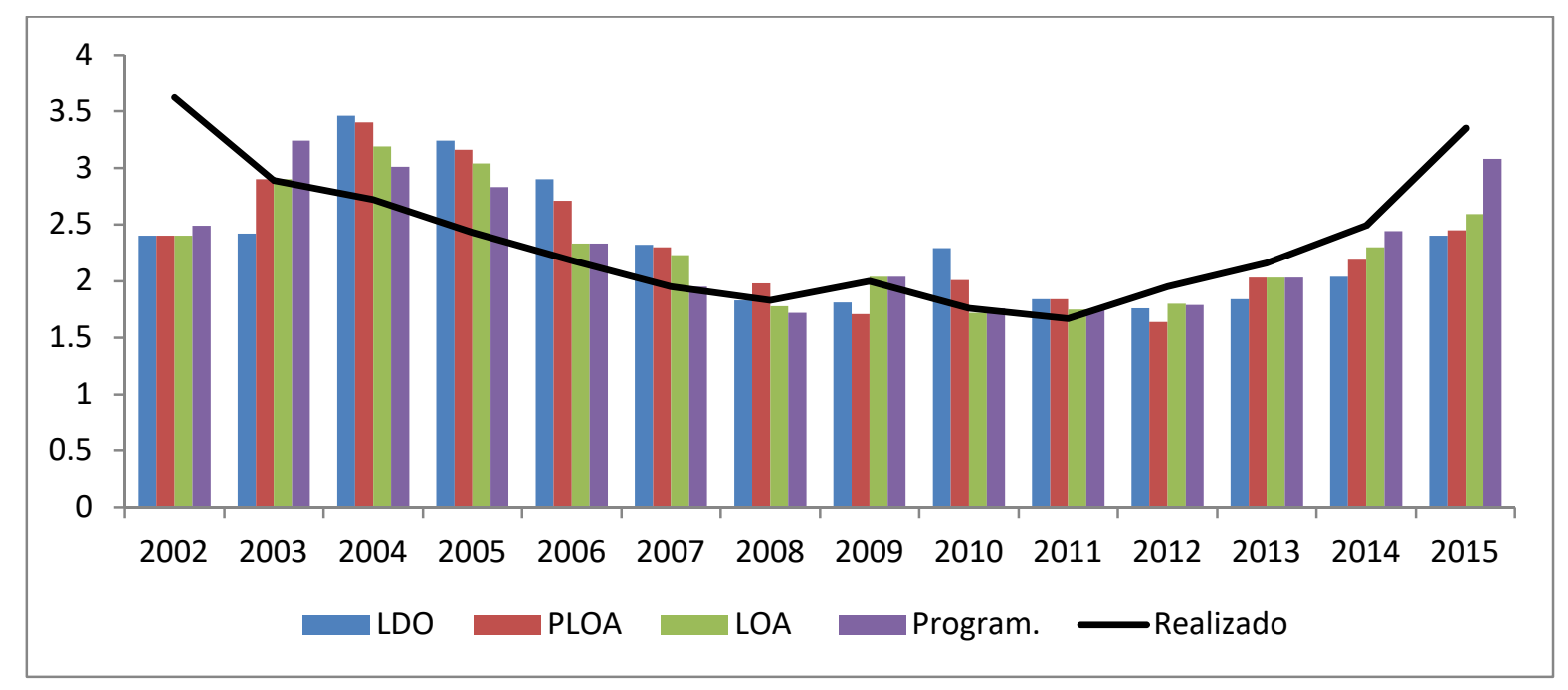

Gráfico 12 - Taxa de câmbio, média anual. Valores previstos e realizados FONTE: Dados da Pesquisa. 


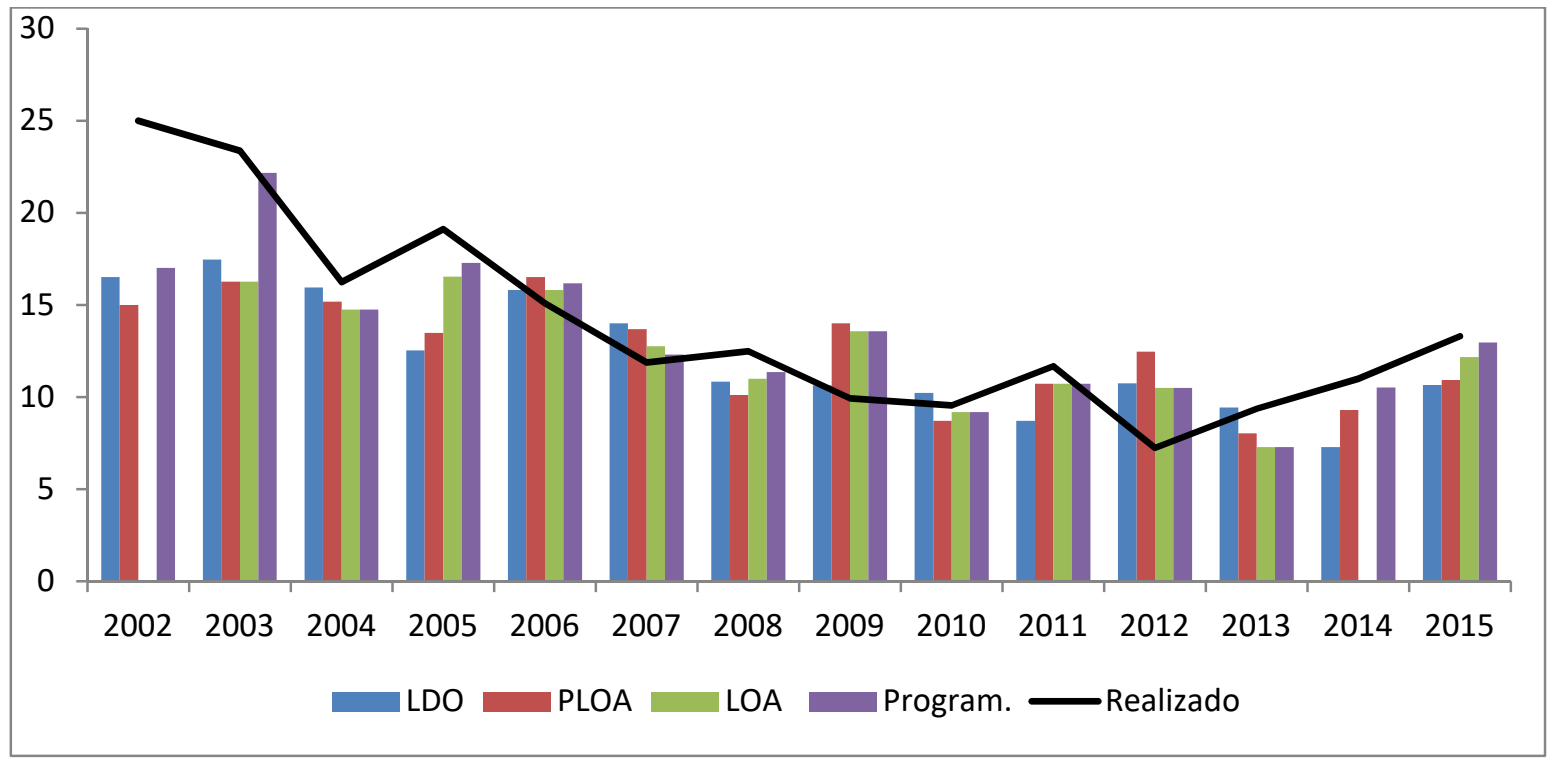

Gráfico 13 - Taxa de juros Selic, média anual. Valores previstos e realizados FONTE: Dados da Pesquisa.

Por fim, os principais parâmetros macroeconômicos levados em consideração na preparação do orçamento incluem também previsões para a variação anual da massa salarial. As previsões para essa variável só estão presentes no orçamento a partir de 2004. O Gráfico 14 apresenta os valores realizados e os valores previstos na LOA para a variação anual da massa salarial de um ano para outro. A variação observada da massa salarial superou a variação prevista em praticamente todos os anos sob análise. As exceções ocorreram nos anos de 2004, 2009 e nos anos de 2014 e 2015 nos quais a massa salarial observada passou a se reduzir fortemente.

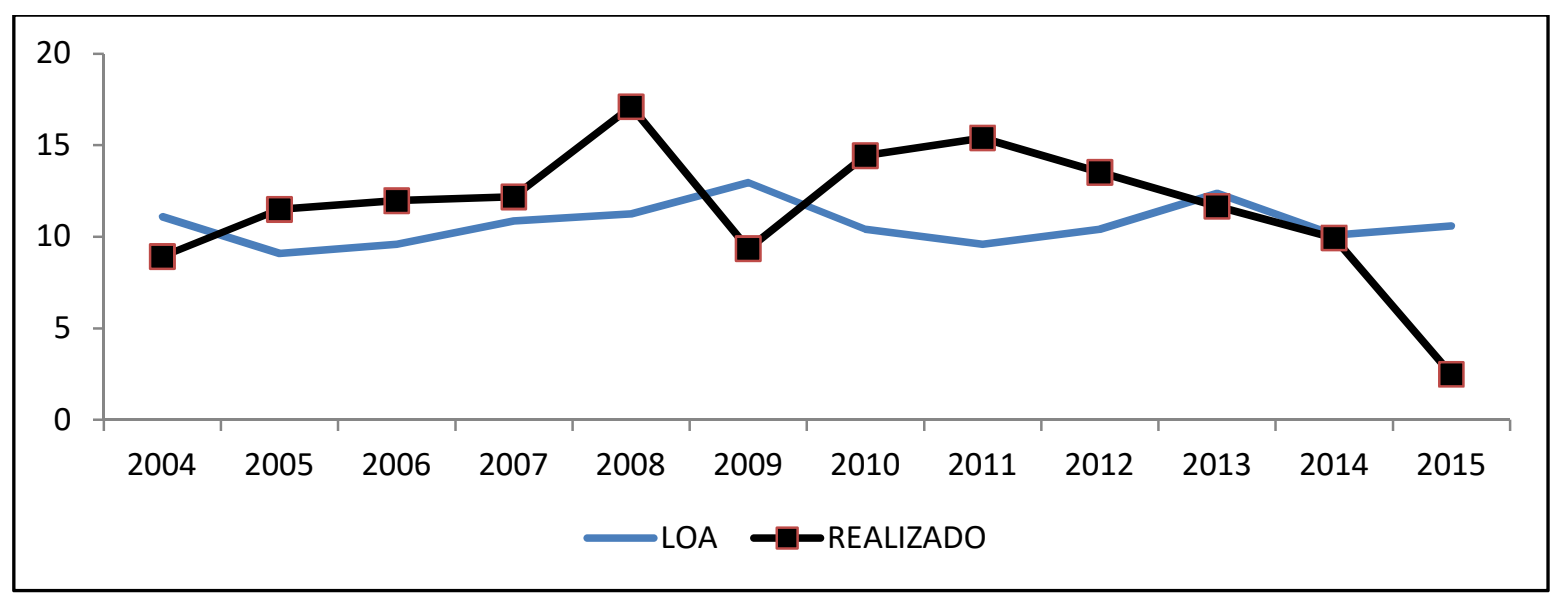

Gráfico 14 - Massa salarial, variação anual. Valores previstos na LOA e realizados FONTE: Dados da Pesquisa. 
A comparação das previsões contidas nas diversas fases do planejamento orçamentário permite-nos verificar as alterações nas previsões fiscais que são feitas pelo Congresso Nacional durante a fase em que a Proposta Orçamentária está sendo avaliada. No capítulo anterior dissemos que o papel do Congresso no planejamento orçamentário amadureceu, na medida em que houve uma profissionalização do processo de reestimativa de receitas. No entanto, o objetivo implícito na reestimativa da arrecadação é permitir receitas em volume suficiente para incluir o máximo possível das emendas parlamentares. Podemos fazer essa inferência ao analisarmos as alterações de receitas e despesas que os parlamentares realizam nas propostas orçamentárias encaminhadas pelo Executivo.

Embora, a LRF determine que reestimativas de receita por parte do Poder Legislativo só serão admitidas se houver comprovado erro ou omissão de ordem técnica ou legal (Art. 12, § $1^{\underline{o}}$ ), na prática o que vemos é que o Congresso frequentemente modifica as propostas orçamentárias enviadas pelo Executivo, tanto em relação à LDO quanto em relação a LOA. Com raras exceções, o que vemos é que o Congresso eleva as estimativas de arrecadação e de despesas propostas pelo Executivo sob a justificativa frequente de reestimação dos parâmetros macroeconômicos e inclusão de receitas extraordinárias não consideradas na proposta original.

A Tabela 2 detalha os valores da receita primária total e da despesa primária total propostas pelo Executivo na PLOA (coluna 3). A coluna 4 apresenta os valores estimados e aprovados pelo Congresso na Lei Orçamentária. A coluna 5 traz os valores que são reestimados pelo Executivo quando da publicação do Decreto de Programação Orçamentária e Desembolso Financeiro que ocorre em até 30 dias após a publicação da LOA. A última coluna traz os valores efetivamente realizados. 
Tabela 2 - Alterações na PLOA e valores realizados - R \$ bilhões

\begin{tabular}{|c|c|c|c|c|c|}
\hline Ano & Item & PLOA & LOA & $\begin{array}{c}\text { Decreto } \\
\text { Programação }\end{array}$ & Realizado \\
\hline \multirow{2}{*}{2002} & Receita Primária & 308,30 & 322,13 & 312,80 & 324,00 \\
\hline & Despesa Primária & 277,98 & 291,35 & 233,40 & 241,80 \\
\hline \multirow{2}{*}{2003} & Receita Primária & 327,90 & 352,73 & 357,70 & 360,30 \\
\hline & Despesa Primária & 295,85 & 318,68 & 262,40 & 263,80 \\
\hline \multirow{2}{*}{2004} & Receita Primária & 402,20 & 413,50 & 406,50 & 424,70 \\
\hline & Despesa Primária & 299,60 & 303,70 & 302,50 & 311,3 \\
\hline \multirow{2}{*}{2005} & Receita Primária & 457,40 & 482,50 & 467,30 & 490,70 \\
\hline & Despesa Primária & 342,10 & 356,80 & 346,60 & 357,90 \\
\hline \multirow{2}{*}{2006} & Receita Primária & 526,20 & 546,00 & 530,90 & 545,40 \\
\hline & Despesa Primária & 391,00 & 407,10 & 390,30 & 405,40 \\
\hline \multirow{2}{*}{2007} & Receita Primária & 603,70 & 618,27 & 598,60 & 620,36 \\
\hline & Despesa Primária & 447,51 & 461,12 & 452,40 & 460,62 \\
\hline \multirow{2}{*}{2008} & Receita Primária & 682,72 & 687,58 & 687,90 & 717,44 \\
\hline & Despesa Primária & 516,73 & 515,72 & 516,50 & 504,41 \\
\hline \multirow{2}{*}{2009} & Receita Primária & 808,88 & 805,30 & 805,30 & 740,63 \\
\hline & Despesa Primária & 606,54 & 608,52 & 609,8 & 581,51 \\
\hline \multirow{2}{*}{2010} & Receita Primária & 853,61 & 873,90 & 873,90 & 921,06 \\
\hline & Despesa Primária & 660,70 & 687,99 & 687,99 & 708,91 \\
\hline \multirow{2}{*}{2011} & Receita Primária & 967,63 & 990,47 & 971,38 & 991,04 \\
\hline & Despesa Primária & 751,19 & 773,58 & 725,30 & 734,48 \\
\hline \multirow{2}{*}{2012} & Receita Primária & $1.097,34$ & $1.127,32$ & $1.090,91$ & $1.060,25$ \\
\hline & Despesa Primária & 837,99 & 864,00 & 811,32 & 812,99 \\
\hline \multirow{2}{*}{2013} & Receita Primária & $1.229,51$ & $1.253,37$ & $1.253,37$ & $1.178,99$ \\
\hline & Despesa Primária & 942,54 & 964,55 & 965,39 & 920,09 \\
\hline \multirow{2}{*}{2014} & Receita Primária & $1.315,35$ & $1.331,61$ & $1.302,68$ & $1.221,47$ \\
\hline & Despesa Primária & $1.040,82$ & $1.052,93$ & $1.007,64$ & $1.040,22$ \\
\hline \multirow{2}{*}{2015} & Receita Primária & $1.465,82$ & $1.447,83$ & $1.371,70$ & $1.248,64$ \\
\hline & Despesa Primária & $1.149,26$ & $1.168,12$ & $1.102,99$ & $1.158,70$ \\
\hline
\end{tabular}

FONTE: PLOA, LOA, Relatórios Trimestrais de Cumprimento de Metas Fiscais.

A partir da observação dos dados da Tabela 2, podemos fazer algumas inferências a respeito da relação entre Executivo e Congresso no processo orçamentário. O Governo envia a proposta orçamentária com valores de arrecadação e despesas relativamente subestimados e permite que o Congresso os eleve para que as emendas dos parlamentares sejam incluídas na lei orçamentária. No geral, as alterações nas estimativas realizadas pelo Congresso não são vetadas pelo Governo. No entanto, após a aprovação da lei orçamentária, sob a justificativa de revisão nos parâmetros macroeconômicos, o Governo frequentemente reduz as estimativas de arrecadação e de despesas que o Congresso havia elevado. Agindo dessa forma, o Executivo adia os conflitos com os parlamentares para a fase de execução orçamentária, no momento em que decreta o contingenciamento de parte das despesas previstas na LOA. 
De acordo com Musso e Phillips (2002), as previsões podem ser avaliadas com base em três princípios básicos: grau de acurácia, ausência de correlação dos desvios de execução e ausência de viés. A acurácia mede a distância entre a previsão e o valor observado da variável. A ausência de correlação implica que os desvios não podem estar correlacionados com os desvios do período passado nem com qualquer informação disponível no momento em que a previsão foi realizada. A ausência de viés implica que, na média, os desvios de execução devem ser zero. A literatura comumente utiliza três medidas convencionais de erro para avaliar a performance relativa das previsões: o Erro Médio (EM), o Erro Absoluto Médio (EAM) e a Raiz do Erro Quadrado Médio (REQM) (como em Strauch et alli, 2004; Leal et alli, 2007; Poplawski-Ribeiro e Rülke, 2011). As referidas medidas de erro são computadas da seguinte maneira:

O Erro Médio (EM) é a diferença média entre a previsão e o valor realizado. É um indicativo da existência de viés, ao avaliar se os desvios positivos e negativos se anulam reduzindo o tamanho do erro.

$E M=\frac{1}{T} \sum_{t=1}^{T} e_{1, t+h}$

T é o número de observações para cada horizonte de previsão $t+h$.

O Erro Absoluto Médio (EAM) é a diferença absoluta média entre o resultado e a previsão.

$E A M=\frac{1}{T} \sum_{t=1}^{T}\left|e_{1, t+h}\right|$

A Raiz do Erro Quadrado Médio (REQM) é uma medida do tamanho relativo do erro de previsão. Considera que desvios maiores são mais prejudiciais do que desvios pequenos.

$$
R E Q M=\sqrt{\frac{1}{T} \sum_{t=1}^{T} e_{1, t+h}^{2}}
$$


As Tabelas 3 a 5 a seguir apresentam o cálculo das referidas medidas de erros para a Receita e Despesa Primárias e para as principais variáveis macroeconômicas utilizadas para fundamentar a previsão orçamentária: IPCA, Selic, taxa de câmbio, IGP-DI e taxa de crescimento do PIB. Para cada variável foi calculado o EM, o EAM e o REQM. Os cálculos foram efetuados por período de tempo para que fosse possível compara-los. Primeiro, são apresentados os cálculos para o período total da pesquisa, de 2002 a 2015. Posteriormente, os cálculos correspondem, respectivamente, aos 8 anos completos de mandato do Presidente Lula (2003 a 2010), e, individualmente, aos 4 anos de cada um dos 2 mandatos (de 2003 a 2006 e de 2007 a 2010. Na sequência são apresentados os cálculos para os 5 anos de mandato da Presidente Dilma Rousseff (de 2011 a 2015), além dos resultados para o primeiro mandato e para o ano de 2015, primeiro ano do segundo mandato atual e último ano da pesquisa. Também foram feitos cálculos para o ano de 2002 que corresponde ao último ano do governo Fernando Henrique Cardoso e primeiro ano da nossa base de dados.

Tabela 3 - Avaliação Desvios de execução: Receita, Despesa e IPCA

\begin{tabular}{l|ccc|ccc|ccc}
\hline \multirow{2}{*}{ Período } & \multicolumn{3}{|c|}{ Receita } & \multicolumn{3}{c|}{ Despesa } & \multicolumn{3}{c}{ IPCA } \\
\cline { 2 - 10 } & EM & EAM & REQM & EM & EAM & REQM & EM & EAM & REQM \\
\hline $2002-2015$ & -11.36 & 31.73 & 52.75 & 0.25 & 16.27 & 22.87 & 0.65 & 1.05 & 1.99 \\
2002 & 8.58 & 8.58 & 9.58 & -2.43 & 14.23 & 21.52 & 6.63 & 6.63 & 6.75 \\
$2003-2010$ & 12.68 & 17.46 & 27.39 & -0.13 & 11.66 & 16.67 & -0.03 & 0.53 & 0.69 \\
$2003-2006$ & 6.70 & 8.36 & 10.51 & 1.80 & 4.06 & 5.44 & -0.07 & 0.72 & 0.84 \\
$2007-2010$ & 18.66 & 26.55 & 37.28 & -2.05 & 19.26 & 22.94 & 0.02 & 0.34 & 0.49 \\
$2011-2015$ & -53.80 & 59.20 & 81.07 & 1.37 & 24.05 & 30.44 & 0.52 & 0.76 & 1.11 \\
$2011-2014$ & -33.95 & 40.70 & 50.95 & -6.85 & 19.93 & 24.97 & 0.09 & 0.39 & 0.54 \\
2015 & -133.21 & 133.21 & 149.93 & 34.27 & 40.55 & 46.26 & 2.22 & 2.22 & 2.24 \\
\hline
\end{tabular}

Fonte: Dados da Pesquisa.

Em relação aos Desvios de execução da receita e da despesa, os dados apresentados na Tabela 3 confirmam as afirmações já feitas neste capítulo de que os desvios aumentaram mais fortemente a partir do segundo mandato do Presidente Lula, ampliando-se ainda mais durante o Governo da Presidente Dilma. O EM, o EAM e o REQM são maiores no período de 2011 a 2015, sendo que o ano de 2015 apresenta o maior desvio.

Para o período completo de 2002 a 2015, há um viés negativo de -11.36 na receita primária, isto é, a receita observada foi inferior à receita prevista em média em $\mathrm{R} \$ 11.36$ bilhões. $\mathrm{Na}$ avaliação dos subperíodos, houve um viés positivo entre 2002 e 2010, no qual a receita prevista subestimou a arrecadação verdadeira. $\mathrm{O}$ viés se reverteu fortemente para negativo a partir de 2011. No ano de 2015, o viés foi mais de 10 vezes maior do que o viés observado na 
amostra completa. Em relação à acurácia das previsões de receita primária, o EAM e a REQM apontam maior acurácia nas previsões realizadas no ano de 2002 e no primeiro mandato do Governo Lula, de 2003 a 2006. O REQM, que penaliza os desvios maiores, mostra que os erros observados em 2015 são aproximadamente três vezes maiores que os erros observados no período completo. O REQM mais elevado que o EAM reflete os desvios relativamente maiores ocorridos nos últimos anos da amostra.

No que se refere à despesa primária, o viés foi próximo a zero para o período total, mas, assim como ocorreu com os desvios da receita, houve uma piora no viés ocorrido nos últimos anos da amostra. O subperíodo de 2015 apresentou um viés positivo em magnitude bastante maior do que os vieses dos demais subperíodos, indicando que as despesas do último ano estiveram bastante acima dos valores previstos. Quanto à acurácia, o subperíodo de 2003 a 2006 apresentou o melhor resultado, com o menor erro medido pelo EAM e REQM. Por outro lado, os anos de 2011 a 2014 e o ano de 2015 apresentaram os maiores desvios.

A significativa piora nas medidas de erro da receita e da despesa a partir de 2011 indica que houve uma deterioração da capacidade de previsão e antecipação dos resultados fiscais que não foram corrigidos ao longo do período em análise. $\mathrm{O}$ excesso de otimismo verificado no período reflete a dificuldade do governo em antecipar a queda na atividade econômica ocorrida nos últimos anos.

A última coluna da Tabela 3 e a Tabela 4 trazem as medidas de erro calculadas para as variáveis macroeconômicas mais usualmente utilizadas para as previsões orçamentárias. Em relação ao IPCA, dois subperíodos se destacam: o ano de 2002 que apresenta o maior viés e a menor acurácia entre todos os demais subperíodos, e o ano de 2015 que também apresenta viés positivo elevado e baixa acurácia. No ano de 2002, em função da crise de confiança pela qual a economia brasileira passou, a meta de inflação não foi cumprida e o IPCA fechou o ano com uma variação anual acumulada de $12.53 \%$, a mais alta entre os anos sob análise, enquanto a meta de inflação era de $3.5 \%$. 
Tabela 4 - Avaliação Desvios de execução: Selic, Taxa de Câmbio e IGP-DI

\begin{tabular}{l|ccc|ccc|ccc}
\hline \multirow{2}{*}{ Período } & \multicolumn{3}{|c|}{ SELIC } & \multicolumn{3}{c|}{ Câmbio } & \multicolumn{3}{c}{ IGP-DI } \\
\cline { 2 - 10 } & EM & EAM & REQM & EM & EAM & REQM & EM & EAM & REQM \\
\hline $2002-2015$ & 0.67 & 1.26 & 2.31 & -0.02 & 0.15 & 0.20 & 0.42 & 1.88 & 2.75 \\
2002 & 7.40 & 7.40 & 7.57 & 0.21 & 0.40 & 0.42 & 4.63 & 6.42 & 6.61 \\
$2003-2010$ & 0.16 & 0.62 & 0.98 & -0.11 & 0.15 & 0.20 & -0.22 & 1.43 & 1.97 \\
$2003-2006$ & 0.42 & 0.78 & 1.07 & -0.19 & 0.19 & 0.24 & -0.52 & 1.50 & 2.04 \\
$2007-2010$ & -1.00 & 0.46 & 0.89 & -0.04 & 1.00 & 0.13 & 0.09 & 1.35 & 1.89 \\
$2011-2015$ & 0.14 & 1.06 & 1.41 & 0.08 & 1.00 & 0.13 & 0.58 & 1.71 & 2.48 \\
$2011-2014$ & -1.00 & 1.06 & 1.49 & 0.06 & 0.08 & 1.00 & -0.48 & 0.94 & 1.39 \\
2015 & 1.06 & 1.06 & 1.07 & 0.18 & 0.19 & 0.21 & 4.78 & 4.78 & 4.81 \\
\hline \multicolumn{4}{c}{ Fonte: Dados da Pesquisa. }
\end{tabular}

Quanto às medidas de erro calculadas para Selic, Taxa de Câmbio e IGP-DI, os resultados seguem o mesmo comportamento identificado para o IPCA, isto é, o ano de 2002 é o subperíodo com as maiores medidas de erro, seguido pelo ano de 2015. Nos demais subperíodos, os desvios são relativamente menores.

A Tabela 5 apresenta as medidas de erro para a taxa de crescimento real do PIB. A fim de adotarmos um critério adicional de avaliação, comparamos a previsão do PIB realizada pelo Governo ao longo do ciclo orçamentário com a previsão realizada pelo mercado, divulgada pelo Banco Central do Brasil. ${ }^{42}$

Tabela 5 - Avaliação Desvios de execução: PIB (\% crescimento real)

\begin{tabular}{l|cc|cc|cc}
\hline \multirow{2}{*}{ Período } & \multicolumn{2}{|c|}{ EM } & \multicolumn{2}{c|}{ EAM } & \multicolumn{2}{c}{ REQM } \\
\cline { 2 - 7 } & Governo & Mercado & Governo & Mercado & Governo & Mercado \\
\hline $2002-2015$ & -0.74 & -0.37 & 1.27 & 1.01 & 1.53 & 0.89 \\
2002 & -0.55 & -0.42 & 0.65 & 0.59 & 1.33 & 0.65 \\
$2003-2010$ & -0.21 & 0.18 & 1.13 & 0.98 & 1.44 & 1.09 \\
$2003-2006$ & -0.67 & -0.28 & 1.31 & 0.95 & 1.21 & 1.11 \\
$2007-2010$ & 0.25 & 0.63 & 0.96 & 0.93 & 1.88 & 1.57 \\
$2011-2015$ & -1.62 & -1.22 & 1.62 & 1.22 & 1.80 & 1.13 \\
$2011-2014$ & -1.51 & -0.91 & 1.51 & 0.91 & 2.16 & 1.26 \\
2015 & -2.03 & -0.37 & 2.03 & \multicolumn{3}{c}{ Fonte: Dados da Pesquisa. }
\end{tabular}

O período com maior desvio de execução do PIB coincide com o período que apresentou o maior desvio relacionado à receita. Em relação às previsões realizadas pelo Governo, há um viés negativo na previsão do PIB, indicando que as previsões de crescimento foram superestimadas. Assim como ocorreu com a receita, o menor desvio de execução do PIB

\footnotetext{
${ }^{42}$ Os dados são bimestrais, retirados do Sistema Gerador de Séries Temporais do Banco Central, Expectativas de Mercado, mediana das expectativas para o PIB total anual realizadas mensalmente no ano t para o próprio ano $t$, seguindo o mesmo formato das previsões bimestrais orçamentárias utilizadas nesta pesquisa. A previsão adotada foi a primeira previsão divulgada no início de cada bimestre do ano t.
} 
ocorreu entre 2003 e 2010 e o maior ocorreu no ano de 2015. O viés cresceu substancialmente de 2011 em diante, acima do dobro do desvio do período completo. Por outro lado, o menor viés ocorreu entre 2007 e 2010, embora esse tenha sido um período de desvio de receita relativamente elevado. Em outras palavras, não é possível associar o excesso de arrecadação acima do previsto durante os anos de 2007 a 2010 a surpresas positivas no crescimento do PIB, haja vista que as previsões de crescimento foram otimistas ao longo de todo esse período. Quanto à previsão do mercado, o viés é menor que o viés relativo à previsão do Governo em praticamente todos os subperíodos da amostra, exceto entre 2007 e 2010.

No que diz respeito à acurácia, as medidas de erros EAM e REQM também indicam piora nas previsões a partir de 2011 tanto nas previsões de Governo quanto nas previsões de mercado. No entanto, as previsões do mercado são mais acuradas do que as previsões orçamentárias oficiais, indicando que, no período sob análise, o setor privado previu a taxa de crescimento do PIB de forma mais eficiente do que o setor público.

Na Tabela 6 comparamos os desvios de execução da Receita, Despesa e do PIB ao longo das diferentes fases de planejamento do orçamento: LDO, PLOA, LOA e o Decreto de Programação que dá início à execução orçamentária. O viés deve ser menor e a acurácia deve ser melhor quanto mais próxima a previsão estiver da data final de realização do evento previsto. Dessa forma, podemos esperar que as medidas de erro sejam decrescentes da LDO para o Decreto de Programação.

Tabela 6 - Desvios de execução: Comparações Planejamento Orçamentário

\begin{tabular}{l|ccc|ccc|ccc}
\hline \multirow{2}{*}{ Fase } & \multicolumn{3}{c}{ Receita } & \multicolumn{3}{c|}{ Despesa } & \multicolumn{3}{c}{ PIB } \\
\cline { 2 - 10 } & EM & EAM & REQM & EM & EAM & REQM & EM & EAM & REQM \\
\hline LDO & 2.36 & 55.38 & 75.31 & -90.81 & 93.93 & 112.90 & -2.12 & 2.89 & 3.35 \\
PLOA & -14.74 & 52.41 & 75.83 & -1.05 & 19.08 & 22.50 & -1.84 & 2.60 & 3.1 \\
LOA & -29.1 & 45.07 & 72.88 & -15.7 & 19.95 & 27.03 & -1.65 & 2.27 & 2.56 \\
Programação & -8.00 & 47.64 & 70.76 & 6.28 & 18.49 & 24.29 & -1.28 & 2.01 & 2.18 \\
\hline
\end{tabular}

Fonte: Dados da Pesquisa.

No que se refere à receita, o viés é maior quando medido a partir das previsões contidas na Lei Orçamentária. Podemos notar que o viés aumenta entre a PLOA e a LOA e depois decresce na programação financeira e orçamentária. O aumento do viés entre a PLOA e a LOA reflete as alterações que o Congresso faz nas previsões de arrecadação encaminhadas pelo Governo. Podemos observar também que, curiosamente, o viés é menor em relação às 
previsões contidas na LDO. Em média, as previsões contidas na LDO apresentaram um viés menor do que as previsões contidas na LOA. Quanto à acurácia, o EAM e a REQM indicam que as previsões tornaram-se mais acuradas entre as fases da LDO e da programação financeira.

Quanto a despesa e à taxa de crescimento do PIB, os maiores desvios ocorreram em relação às previsões da LDO, indicando uma melhora nas previsões dessas variáveis ao longo do processo de planejamento. O viés da despesa é menor em relação à PLOA, indicando que as previsões contidas na Proposta Orçamentária eram menos viesadas do que as previsões que foram aprovadas pelo Congresso. O PIB, por outro lado, apresenta medidas de erro declinantes da LDO para a Programação, em coerência com a ideia de que quanto menor o horizonte temporal para o qual a previsão é feita, menores são os desvios observados.

Em resumo, este capítulo permitiu-nos verificar uma piora na previsão orçamentária ocorrida a partir de 2009 e um agravamento nessas previsões a partir de 2012. No capítulo seguinte, tentaremos identificar de forma descritiva os fatos capazes de explicar os desvios de execução observados ao longo do capítulo atual. 
A EXECUÇÃo ORÇAMENTÁRIA NO PERÍODO DE 2002 A 2015

\title{
5.1
}

\author{
Introdução
}

Este capítulo apresenta uma descrição dos eventos que influenciaram o planejamento e os desvios de execução orçamentários do período de 2002 a 2015. O objetivo é compreender os fatos que atuaram para que esses desvios ocorressem e a atuação do Governo nos resultados encontrados. Para isso, olhamos para a intencionalidade (divulgada) do Governo no momento da elaboração do orçamento e para os eventos que condicionaram sua execução. Muito mais do que analisar os valores efetivamente realizados de receita e de despesa, estamos interessados em identificar possíveis determinantes dos desvios desses valores em relação aos valores orçados. A análise levará em conta o cenário macroeconômico no qual o planejamento fiscal foi elaborado e executado, o ajuste das receitas estimadas e das despesas ao cenário desenhado e a compatibilização dos resultados com as metas estabelecidas.

Para atingirmos o objetivo proposto, na seção seguinte analisaremos o desvio de execução orçamentário ocorrido no ano de 2002. Na terceira seção, nosso interesse será nos desvios ocorridos durante os anos de 2003 a 2010. Na quarta seção, analisaremos os determinantes dos desvios de execução ocorridos nos anos de 2011 a 2015.

O objetivo desta seção é identificar os fatores que condicionaram o planejamento e os desvios de execução orçamentários do último ano do Governo Fernando Henrique Cardoso. A análise inicia-se um ano antes, em 2001, quando o orçamento para 2002 foi preparado. 
A despeito de um cenário de desaceleração da economia global ${ }^{43}$ e dos condicionantes internos $^{44}$ que dominaram a pauta econômica ao longo de todo o ano de 2001, as expectativas do governo para a economia brasileira para o ano de 2002 eram inicialmente favoráveis. As metas fiscais contidas no Projeto de Lei de Diretrizes Orçamentárias 2002 refletiam os critérios de desempenho estabelecidos no acordo de empréstimo assinado com o FMI em novembro de $1998^{45}$. Embora, a princípio, 2001 seria o último ano do acordo, no entanto, como veremos, o acordo precisou ser estendido.

O Anexo de Metas Fiscais da LDO 2002 atribuiu à relação dívida/PIB o papel de variável mais importante no longo prazo para conferir credibilidade à política macroeconômica. $\mathrm{O}$ documento afirmou a necessidade de buscar a trajetória estável dessa relação para que a política fiscal pudesse ser utilizada de forma contracíclica quando se fizesse necessário e para que o risco fiscal dos investimentos realizados no país fosse reduzido. O controle da relação dívida/PIB seria, portanto, o objetivo último da gestão fiscal que deveria ser alcançado através do cumprimento das metas de superávit primário ${ }^{46}$. Ainda de acordo com o exposto no Anexo de Metas Fiscais, os únicos instrumentos com os quais a política fiscal poderia contar para atingir seu objetivo seriam a elaboração e o controle do orçamento, demais variáveis que afetam a relação dívida e PIB estariam fora do alcance da política.

\footnotetext{
${ }^{43}$ No ano de 2001, a economia brasileira foi marcada por uma crise de confiança que gerou fortes pressões sobre a taxa de câmbio, levando ao contágio da depreciação cambial sobre o nível de preços, e ao descumprimento da meta de inflação. No âmbito externo, as pressões sobre o câmbio foram provenientes da deterioração da situação política e econômica da Argentina, da crise cambial na Turquia com reflexos no custo do financiamento externo para os países emergentes e do agravamento na desaceleração da economia norte-americana, especialmente após $\mathrm{o}$ ataque terrorista de 11 de setembro. Adicionalmente, a economia mundial estava em desaceleração também em função do Japão, cuja atividade econômica estava em grave queda. Como reflexo, a Zona do Euro e os países exportadores asiáticos também foram afetados pela crise americana e japonesa.

${ }^{44}$ No âmbito interno, o ano de 2001 foi marcado pela instabilidade política gerada por investigações na administração pública, pelo quadro de restrição à oferta de energia elétrica, e pela expectativa de redução no ritmo de ingresso de investimentos estrangeiros, com forte impacto sobre o financiamento do déficit em conta corrente.

${ }^{45}$ Em 1998, diante de uma grave crise nos países emergentes, agravada no Brasil pelas constantes dificuldades para manter a âncora cambial do Plano Real e pela deterioração das contas públicas, o Brasil assinou um acordo de ajuda financeira com o FMI para o período de 1999 a 2001. Em contrapartida aos recursos do empréstimo, o país se comprometeu a cumprir os critérios de desempenho estabelecidos pelo Fundo, entre os quais havia metas de superávit primário a serem alcançadas durante toda a vigência do acordo, metas de desempenho para a dívida externa e limites máximos para a necessidade de financiamento do setor público. O plano de ajuste fiscal definido por ocasião do acordo com o FMI foi chamado de Programa de Estabilidade Fiscal (PEF). O acordo de 1998 foi posteriormente revisto em 1999 após a desvalorização cambial. Novos acordos foram assinados em 2001 e 2002.

${ }^{46}$ Em 2000, o Brasil e os demais países do Mercosul assinaram um acordo de metas e de mecanismos de convergência macroeconômica. Este acordo estabelecia, para todos os países membros, um limite para a variação da dívida fiscal líquida do setor público consolidado. A necessidade de financiamento do setor público não poderia ultrapassar 3,5\% do PIB entre 2002 e 2003, e 3\% do PIB a partir de 2004. Porém, como Giambiagi (2002) afirmou, não havia nenhum mecanismo de garantia de cumprimento do acordo e, na prática, a política fiscal continuou sendo fundamentada em pisos de superávit primário e não em tetos de déficit nominal.
} 
Merece registro o fato de que a Constituição Federal não estabelece um limite nominal para as despesas ou para a dívida mobiliária ${ }^{47}$. Há apenas metas para o superávit primário e nominal que foram normatizadas a partir da Lei de Responsabilidade Fiscal em 2000 e passaram a constar do Anexo de Metas Fiscais da LDO. As despesas podem atingir qualquer valor nominal desde que sejam proporcionais às receitas previstas e garantam o cumprimento da meta de superávit primário. Exceção é feita em relação aos gastos totais com pessoal que não podem exceder o percentual da receita corrente líquida de 50\% no caso da União e $60 \%$ para Estados e Municípios, conforme determinado pela LRF.

No que se refere à arrecadação, a LDO previu que as receitas projetadas para os anos seguintes pudessem ficar abaixo dos níveis estimados para 2001 em função da redução nas receitas de concessões e das mudanças previstas na legislação a cerca da alíquota de imposto de renda pessoa física (IRPF). A esse respeito, estava previsto para 01 de janeiro de 2003 o retorno da alíquota máxima do imposto de renda pessoa física para $25 \%$ sobre a parcela de rendimentos acima de $\mathrm{R} \$ 1.800,00$, com dedução de $\mathrm{R} \$ 315,00$. Ressalta-se que a alíquota do IRPF era de $25 \%$ até dezembro de 1997, quando então foi elevada para 27,5\% para vigorar entre 01 de janeiro de 1998 até 31 de dezembro de 1999. No entanto, a elevação da tarifa foi prorrogada até $31 / 12 / 2002$, quando deveria voltar para $25 \%$.

Contudo, a principal preocupação do Governo no tocante à arrecadação dizia respeito à perda de receita com a CPMF, cuja vigência acabaria em julho de 2002. Na ocasião, a CPMF era o quarto tributo em importância de magnitude de acordo com informação contida na Mensagem que encaminhou a LDO. Caso a prorrogação desta contribuição não fosse aprovada pelo Congresso, haveria uma significativa perda de arrecadação a partir do segundo semestre de 2002 (aproximadamente R\$ 19 bilhões). Com a indefinição sobre a prorrogação da CPMF, a

\footnotetext{
${ }^{47}$ A Constituição Federal de 1988 atribui ao Senado a responsabilidade de fixar os limites globais para o montante da dívida consolidada da União, Estados e Municípios (art. 52, inciso IX) e ao Congresso Federal a responsabilidade de fixar os limites para o montante da dívida mobiliária federal (art. 48, inciso XIV). A LRF determinou o prazo para que o Executivo enviasse, respectivamente, ao Senado e ao Congresso, as propostas com os respectivos limites. Após a promulgação da LRF, o Senado editou a Resolução n. 40 de 2001, estabelecendo o limite de endividamento dos Estados e Municípios. No caso dos Estados, a partir de 2016, a Dívida Consolidada Líquida (DCL) não poderá exceder 2 vezes a Receita Corrente Líquida (RCL). Para os Municípios, a relação é de 1,2 vezes a RCL. Os excedentes em relação a esses limites, apurados no ano da publicação da Resolução em 2001, deverão ser reduzidos, no mínimo, à proporção de 1/15 (um quinze avos) a cada exercício financeiro. No caso do endividamento da União, ainda está em tramitação no Senado a proposta para limitar a DCL da União em 3,5 vezes a RCL (Projeto de Resolução do Senado n. 84 de 2007). Quanto ao limite para o montante da dívida mobiliária federal, está em tramitação no Congresso Nacional o Projeto de Lei n. 3431 de 2000 que estabelece o limite de 6,5 vezes a RCL para a dívida pública mobiliária federal.
} 
Lei Orçamentária de 2002 que o Executivo encaminharia ao Congresso deveria conter previsão de receitas já considerando o fim da vigência da cobrança do tributo. Não somente as receitas estimadas deveriam ser reduzidas para se enquadrar no cenário sem CPMF, como também as despesas previstas, o que certamente geraria um problema político para o Governo resolver junto ao Congresso no momento de decidir quais despesas seriam mantidas no orçamento e quais seriam excluídas.

Para lidar com essa questão, o Governo inseriu na LDO dispositivo que autoriza a inclusão no orçamento de receitas que são objeto de propostas em tramitação no Congresso. Em outras palavras, a LDO passou a permitir a inclusão no orçamento de despesas cuja fonte de custeio ainda não esteja garantida. Ao fazer isso, o Governo não só ganhou tempo, como pressionou para que a prorrogação fosse aprovada, ao incluir na apuração do resultado primário planejado receitas condicionadas à aprovação do Congresso. Caso as propostas de alterações tributárias e das contribuições em tramitação no Congresso não fossem aprovadas ou fossem aprovadas parcialmente até o final do primeiro semestre, as receitas correspondentes seriam canceladas por Decreto até o prazo de 31/07/2002.

Assim, além dos riscos naturalmente inerentes a previsão das receitas, como o risco econômico de frustração na taxa de crescimento real do PIB, adicionou-se o risco político, haja vista a aprovação da CPMF depender das negociações entre o Executivo e o Legislativo. Na avaliação da Comissão Mista do Orçamento (CONGRESSO NACIONAL, 2001), ao incluir receitas condicionadas na lei orçamentária, o orçamento se descolava do realismo que deve nortear o planejamento fiscal e as contas públicas.

Nenhum dos eventos negativos que afetaram a economia brasileira em 2001 e 2002 foram antecipados na LDO 2002. Os únicos riscos citados no Anexo de Riscos Fiscais que poderiam frustrar as metas contidas na LDO referiam-se aos passivos contingentes derivados de ações judiciais, às garantias concedidas pela União em operações de crédito e aos passivos relativos às dividas ainda não reconhecidas e não contabilizadas.

As projeções não consideravam a hipótese de ocorrência de novos choques externos. De acordo com o Anexo de Metas Fiscais, ainda que ocorressem, acreditava-se que possíveis choques externos teriam impactos maiores somente no curto prazo e não resultariam em mudanças na política fiscal, a qual só deveria mudar diante de choques permanentes que 
impactassem a solvência do setor público no longo prazo. Também não havia previsão de variações bruscas na taxa de câmbio, variável chave para a determinação da dívida pública. De acordo com o Anexo de Riscos Fiscais do PLDO 2002, uma depreciação de 1\% do Real frente ao Dólar aumentaria em 0,21 ponto percentual a razão dívida/PIB.

O projeto da LDO foi elaborado e encaminhado ao Congresso em abril de 2001 e até aquele momento as perspectivas eram favoráveis. Não somente o Governo Federal estava otimista, o Banco Central também avaliou que as perspectivas para a economia no início de 2001 eram de forte expansão da atividade econômica, conforme expos na ata da reunião do Conselho de Política Monetária (COPOM) realizada em março de 2001. Dessa forma, as receitas para o ano de 2002, 2003 e 2004 foram estimadas com base em uma taxa esperada de crescimento real do PIB de 4,5\%, acompanhado por expectativas de estabilidade cambial (estimou-se uma taxa em torno de R \$2,15/US\$ em dezembro de 2002 e R 2,18 e R 2,21 em 2003 e 2004 respectivamente), queda na taxa de juros nominal (de 13,2\% ao ano em 2002 para 12,3\% em 2004) e manutenção da inflação entre 4 e 3,5\% ao ano.

O cenário econômico começou a se deteriorar a partir de abril de 2001. Entre as causas da reversão na economia destacam-se: a) No âmbito externo, a desaceleração da economia mundial, em especial da economia norte-americana e da japonesa, mostrou-se mais forte do que o esperado, gerando instabilidades nos mercados acionários e de capitais. Como reflexo, a Zona do Euro e os países exportadores asiáticos também foram afetados pela crise nos Estados Unidos e no Japão. Adicionalmente, a situação política e econômica da Argentina e a crise cambial na Turquia, elevaram o prêmio de risco para os mercados emergentes como um todo, gerando saídas de capitais e pressões sobre as taxas de juros dos títulos desses países. b) No âmbito interno, a desaceleração da economia mundial e a saída de capitais dos países emergentes, ampliaram as incertezas em relação ao financiamento do balanço de pagamentos, haja vista que o Brasil já vinha lidando com um déficit comercial em função do aumento das importações e queda das exportações geradas pelo baixo dinamismo da economia mundial. Essas incertezas geraram pressões sobre o câmbio, sobre a inflação e, consequentemente, o Banco Central brasileiro elevou a taxa de juros básica. A esses fatores, soma-se também a crise energética com repercussões negativas sobre a produção.

No segundo semestre de 2001, quando o Brasil estava prestes a encerrar o acordo com o FMI, a situação da economia externa se agravou e as perspectivas de crescimento mundial foram 
revistas drasticamente para baixo, com reflexos em inúmeras economias, sobretudo emergentes, como Turquia, Malasia, Taiwan, Hong Kong e Argentina. O ambiente interno também se deteriorou em função da crise energética. Diante disso, o acordo de 1998 foi cancelado e, em setembro de 2001, um novo programa de crédito com o FMI foi assinado. O novo acordo envolvia recursos da ordem de US\$ 15 bilhões que se destinavam a prevenir os efeitos dos choques externos e estender-se-ia até dezembro de 2002.

Em resposta à crise e, em especial, em função do acordo com o FMI, as metas de superávit primário expressas na LDO de 2001 e na LDO de 2002 foram alteradas. Para 2001, a meta do setor público consolidado aumentou para 3,35\% do PIB (contra os 3\% originalmente estabelecidos) e para 3,5\% em 2002, sendo 2,4\% para o Governo Central, 0,57\% para as Empresas Estatais e o restante para os Estados e Municípios. A expectativa de crescimento também foi revista. Para 2002, a taxa de crescimento real esperada passou de 4,5\% para 3,5\% ao ano. Para 2003 e 2004, o crescimento esperado foi reduzido para 4,0\% (Medida Provisória 2211/2001).

Foi nesse ambiente de deterioração do cenário macroeconômico que o Projeto de Lei Orçamentária Anual (PLOA) para 2002 foi elaborado e encaminhado ao Congresso. Contudo, apesar da conjuntura na qual foi elaborado, as expectativas constantes no PLOA eram extremamente otimistas. De acordo com o exposto pelo Presidente da República na mensagem que encaminhou o Projeto ao Congresso, a crise em 2001 era vista como transitória e as perspectivas eram de reversão das dificuldades já em 2002. De acordo com o documento, Governo e Banco Central estariam adotando todas as medidas de política econômica necessárias para reverter os efeitos da crise, incluindo as medidas de compromisso com a austeridade fiscal e as relacionadas à gestão da crise energética. No âmbito externo, o documento previa a recuperação da economia norte-americana, liderando o crescimento mundial, com efeitos positivos sobre as exportações brasileiras, que também seriam beneficiadas pela depreciação cambial. Nesse quadro de recuperação econômica, as expectativas para 2002 eram de retomada do crescimento, com uma taxa de crescimento real de 3,5\%, acompanhada de inflação medida pelo IPCA de cerca de 3,5\% ao ano e de trajetória de queda das taxas de juros. Vale dizer que em agosto de 2001, no mesmo período em que o PLOA foi enviado ao Congresso, a mediana das expectativas de mercado para o crescimento do PIB em 2002, de acordo com o Boletim Focus, apontavam para uma taxa de 2,90\%. 
O Congresso aprovou a LOA com a mesma expectativa de crescimento de 3,5\% apresentada no Projeto de Lei, porém elevou a expectativa de inflação, medida pelo IGP-DI de 5,96\% para 7,63\%. Além disso, elevou as previsões de receita e de despesa, preservando a meta de superávit primário como proporção do PIB em 2,24\%. A receita primária total, inicialmente estimada em $\mathrm{R} \$ 308,3$ bilhões no PLOA, foi reestimada para $\mathrm{R} \$ 322,1$. A despesa primária total foi fixada em R \$ 291,4 bilhões na LOA contra R \$ 279,1 na PLOA. Das alterações na receita prevista, $\mathrm{R} \$ 2.323,73$ referem-se à correção das estimativas em função do aumento dos índices de preços medidos pelo IGP-DI, após o envio da proposta orçamentária. A quantia restante refere-se a mudanças na estimativa da receita ocorridas durante a tramitação da proposta orçamentária, como por exemplo, reestimativas do Imposto de Renda (IR) e do Imposto sobre Produtos Industrializados (IPI) ${ }^{48}$. O aumento nas despesas esperadas refere-se ao atendimento de emendas parlamentares, ao aumento das transferências constitucionais decorrentes da reestimativa da arrecadação e das despesas com o aumento salarial de servidores e das despesas previdenciárias e sociais decorrentes do aumento adicional do salário mínimo.

Em relação ao salário mínimo, cabe aqui uma explicação. O projeto de lei do orçamento foi encaminhado ao Congresso com uma estimativa implícita de reajuste do salário mínimo de $5,97 \%$, de R\$ 180,00 para 190,71. Essa estimativa foi aprovada no parecer preliminar da CMO (2002, p. 60). Porém, após meses de discussão a respeito de qual seria o reajuste, o Orçamento foi aprovado pelo Congresso, com um reajuste maior para o salário mínimo que passaria de $\mathrm{R} \$ 180,00$ para $\mathrm{R} \$ 200,00$ a partir de 01/04/2000.

A Lei Orçamentária 2002 foi votada em dezembro de 2001 contendo uma expectativa de crescimento de 3,5\%. No mesmo mês, a previsão de crescimento do Banco Central para 2002 era de 2,5\%, segundo o Relatório de Inflação emitido pelo Banco Central em dezembro de 2001, e as expectativas do mercado, expressas no Boletim Focus de 28 de dezembro de 2001, indicavam um crescimento esperado de $2,40 \%$ para 2002. As expectativas para o IPCA, tanto do mercado como do Banco Central, estavam de acordo com a LOA e indicavam uma taxa acima do centro da meta, porém dentro do intervalo de tolerância de 2 pontos percentuais.

\footnotetext{
${ }^{48} \mathrm{O}$ detalhamento das revisões realizadas na expectativa de arrecadação está listado no Relatório Final do Orçamento 2002 emitido pela Comissão Mista de Planos, Orçamentos Públicos e Fiscalização do Congresso Nacional.
} 
As expectativas otimistas para 2002, no entanto, não se realizaram. O ano de 2002 foi caracterizado por crises de confiança na evolução da economia brasileira e por forte aumento da aversão ao risco nos mercados internacionais e esses movimentos condicionaram a execução orçamentária, haja vista o compromisso firme do governo com o cumprimento das metas de superávit primário.

As incertezas quanto à evolução da economia brasileira em 2002 foram decorrentes, por um lado, da instabilidade causada pelo processo eleitoral, e, por outro, do contexto internacional. Havia dúvidas se o novo governo a ser eleito continuaria a se pautar pela disciplina fiscal e se o Banco Central adotaria ou não uma postura complacente em relação à inflação (BLANCHARD, 2004). No âmbito externo, o baixo crescimento mundial, o surgimento de escândalos contábeis em grandes empresas americanas, as crises observadas em países emergentes e a perspectiva de uma nova guerra no Golfo provocaram aumento na aversão ao risco, com consequente redução nos fluxos de capitais internacionais.

Logo após a sanção da LOA, os parâmetros macroeconômicos foram revistos, incorporando uma estimativa de piora no cenário econômico. Dessa forma, o Decreto de Programação Orçamentária e Financeira, editado em 7 de fevereiro de 2002, reviu a previsão de crescimento da economia de 3,5\% para 2,5\%, comparada com a Lei Orçamentária aprovada em dezembro de 2001. Nota-se que a nova previsão de crescimento adotada pelo Executivo era exatamente a mesma previsão utilizada pelo Banco Central e divulgada no Relatório de Inflação de dezembro de 2001. As estimativas de arrecadação também foram reduzidas de R \$ 322,1 bilhões para $\mathrm{R} \$ 313,5$ bilhões. Consequentemente, as despesas foram revistas para baixo, de forma a serem compatíveis com a meta fiscal estabelecida na LDO.

Em função da menor expectativa de arrecadação, e em cumprimento ao art. $9^{\circ}$ da LRF, foram contingenciados R $\$ 10,7$ bilhões nos pagamentos das despesas discricionárias e R $\$ 12,4$ bilhões na movimentação e empenho. Posteriormente, em maio, após a avaliação bimestral do cumprimento da meta, o corte promovido através do Decreto 4.120/2002 confirmou-se necessário. Na verdade, como a prorrogação da CPMF ainda não havia sido aprovada até aquele momento, o Governo promoveu novo contingenciamento de R $\$ 5,3$ bilhões nos valores programados para pagamento e para movimentação e empenho, através do Decreto 4.230/2002 de 14 de maio. 
A partir do segundo trimestre de 2002, a situação da economia brasileira se agravou. Diversos fatores contribuíram para isto. Do lado da demanda externa: o fraco desempenho da economia mundial, em especial, a crise argentina, estavam afetando negativamente as exportações brasileiras. Do lado da demanda interna: os consumidores estavam mais cautelosos, reduzindo a demanda por bens duráveis. $\mathrm{O}$ aumento da aversão ao risco dos investidores estrangeiros e as incertezas sobre os rumos da política econômica associadas ao processo eleitoral estavam retraindo as decisões de investimento. De acordo com Giambiagi (2004) as incertezas associadas ao processo eleitoral estavam presentes por que o Partido dos Trabalhadores (PT) cujo candidato à presidência liderava as pesquisas de opinião, bem como o próprio candidato, já haviam se declarado claramente contrários à política fiscal de geração de superávits primários para o pagamento da dívida, assim como eram contrários, entre outras coisas, à elevação da taxa de juros para conter as expectativas inflacionárias e, caso vencessem a eleição, prometiam recuperar o controle das políticas fiscal e monetária que, segundo eles, estavam a serviço do FMI.

Na verdade, em 22 de junho de 2002, contrariando a postura assumida pelo seu partido e por ele próprio, até aquele momento, Lula que era o principal candidato à eleição, divulgou um documento intitulado "Carta ao Povo Brasileiro" no qual sinalizava ao mercado financeiro que honraria a política econômica do governo FHC e, mais importante, preservaria o superávit primário o quanto fosse necessário para evitar o aumento da dívida interna e a destruição da confiança na capacidade do governo de honrar seus compromissos. Esse documento, embora indicasse uma mudança de postura por parte do candidato, não foi assinado por seu partido e, a despeito da sua importância no contexto da crise de confiança que envolvia o resultado da eleição, não foi suficiente para reduzir as incertezas a cerca do rumo que a política econômica tomaria a partir de 2003.

A retração do fluxo de capitais estrangeiro destinado à economia brasileira ocasionou uma forte depreciação da moeda nacional (cerca de $20 \%$ apenas no segundo trimestre) acompanhado por elevação nos prêmios de risco nos mercados, em decorrência das incertezas a respeito da estabilidade macroeconômica do país. Consequentemente, a expectativa de crescimento da economia foi novamente revista para baixo, para 2,0\%, sinalizando com uma expectativa de frustração da arrecadação do Tesouro Nacional. As despesas obrigatórias com pessoal e encargos sociais, por sua vez, foram revistas para cima, assim como a expectativa de déficit primário da Previdência Social. Diante do novo cenário, o contingenciamento de 
gastos que havia sido realizado anteriormente por meio do Decreto 4.309/2002 foi convertido em corte efetivo de despesas.

Além do ajuste dos gastos às novas expectativas de arrecadação, uma série de medidas adicionais foi adotada no mês de junho para reduzir a instabilidade. Entre estas medidas, a meta de superávit primário para 2002 foi elevada de $3,5 \%$ para $3,75 \%$ do $\mathrm{PIB}^{49}$. O Governo também efetuou um saque de US\$10 bilhões dos recursos relativos ao acordo com o FMI e alterou a meta de inflação de 3,25\% para $4 \%$ em 2003 e 3,75\% em 2004, com intervalo de tolerância de 2,5 pontos percentuais para mais ou para menos nos dois períodos (BCB, 2002). A meta de inflação para 2002 foi mantida em 3,5\%, haja vista que não fazia sentido alterá-la no meio do ano, dadas as características do sistema de metas de inflação e a defasagem de tempo necessária para a ação da política monetária sobre o nível de preços.

Ainda no mês de junho a CPMF foi finalmente prorrogada até dezembro de $2004^{50}$. De acordo com a Emenda Constitucional que a prorrogou (EC n. 37 de 12 de junho de 2002), a alíquota sobre as movimentações e transmissões de valores financeiros continuaria a ser de $0,38 \%$ em 2002 e 2003 e diminuiria para 0,08\% no ano de 2004. Porém, a redução da alíquota não ocorreu em 2004 e tampouco o tributo se extinguiu naquele ano.

Em agosto de 2002, o Governo novamente recorreu ao FMI. O acordo que havia sido realizado em setembro do ano anterior foi cancelado e substituído por um novo Acordo Stand$b y^{51}$, com prazo de 15 meses, no valor de US\$ 30 bilhões, o maior empréstimo, até então, da história do FMI. Desse total, US\$ 10 bilhões seriam desembolsados no âmbito do Programa de Financiamento de Reserva Suplementar ${ }^{52}$. Além da disponibilização dos recursos financeiros, o piso das reservas internacionais líquidas exigido pelo FMI também foi

\footnotetext{
${ }^{49}$ A elevação na meta de superávit primário foi realizada através do Decreto 4.369 de 11 de setembro de 2002. Não foi necessário alterar a LDO, uma vez que esta estabelece um superávit mínimo a ser alcançado, mas não estabelece um limite máximo.

${ }^{50}$ As contribuições requerem um prazo de 90 dias após a publicação da lei que as instituíram para começarem a ser cobradas. Entretanto, a EC n. 37 apenas estendeu o prazo para a cobrança da CPMF, portanto, não houve interrupção na arrecadação desse tributo.

${ }^{51} \mathrm{Na}$ modalidade de empréstimo Stand-by, os recursos aprovados ficam disponíveis ao país, podendo ser utilizados quando necessário, de acordo com os prazos e critérios estabelecidos pelo Fundo. Pelo acordo em questão, o Brasil poderia sacar US\$ 3 bilhões imediatamente após a concretização do acordo e mais US\$ 3 bilhões em dezembro de 2002 após a primeira revisão do acordo. Os US\$ 24 bilhões restantes ficariam disponíveis em 2003 de acordo com o cronograma preestabelecido (BRASIL, 2002).

${ }^{52}$ Através da modalidade Supplemental Reserve Facity, o FMI presta auxílio financeiro aos países membros com problemas excepcionais no financiamento do balanço de pagamentos resultantes, por exemplo, de uma perda súbita da confiança do mercado, com pressões sobre a conta de capital e o estoque de reservas internacionais (IMF, 1997).
} 
reduzido, de um estoque de US\$23,5 bilhões em 31 de julho de 2002 para um mínimo de US\$ 5 bilhões a partir de setembro de 2002 (BRASIL, 2002). Dessa maneira, o Banco Central poderia utilizar o excedente de reservas para reduzir a depreciação cambial.

A meta de superávit primário para 2002 também foi alterada em função da contratação do novo empréstimo. A meta anual para o setor público consolidado, que havia sido fixada em $3,75 \%$ do PIB em junho, passou para 3,88\%. A meta também foi fixada em 3,88\% do PIB para o período de 12 meses compreendido entre julho de 2002 a junho de 2003.

De acordo com o Memorando de Política Econômica de 04 de setembro de 2002, a meta fiscal definida com o FMI tinha o objetivo de estabilizar a dívida líquida do setor público em torno de 59\% do PIB em 2002. No médio prazo, a relação dívida/PIB deveria entrar em uma trajetória declinante. Para atingir esse objetivo, a meta de superávit primário para 2003, que a princípio estava fixada em $3,75 \%$ do PIB, deveria ser revista em cada uma das quatro avaliações do acordo, programadas para ocorrerem nos meses de novembro de 2002, fevereiro, maio e agosto de 2003. As revisões da meta levariam em conta a relação dívida/PIB e as variáveis macroeconômicas, vigentes e esperadas, que impactam a dinâmica da dívida, em especial, a taxa de câmbio real, as taxas de juros reais e o crescimento real do PIB, para definir qual o superávit primário que deveria ser buscado no restante do acordo. Em outras palavras, a meta para 2003 foi inicialmente mantida em 3,75\% do PIB, mas poderia ser elevada em qualquer uma das quatro revisões trimestrais se fosse necessário para estabilizar a relação entre dívida pública e PIB. O referido Memorando também considerou que, para que a relação dívida/PIB fosse mantida em trajetória declinante, a meta de superávit primário para 2004 e 2005 também deveria ser de pelo menos 3,75\% do PIB.

As expectativas em relação ao cenário macroeconômico para 2002 e 2003, por ocasião da assinatura do novo acordo com o FMI, já não eram mais tão otimistas quanto aquelas que nortearam a aprovação do Orçamento. Em agosto de 2002, o Governo estava trabalhando com uma expectativa de crescimento real do PIB de 1,5\% em 2002 e de 2,5\% a 3,5\% em 2003. Merece destaque o fato de que a previsão de crescimento para 2002 utilizada pelo Governo era semelhante à previsão utilizada pelo Banco Central no Relatório de Inflação publicado no mês de setembro de 2002, o qual considerava um taxa de crescimento real de 1,4\% para aquele ano. Em relação às contas externas, em função da depreciação cambial acima da 
inicialmente esperada, as expectativas indicavam uma melhora no saldo comercial e redução no déficit em conta corrente.

A partir de setembro de 2002 o cenário doméstico deteriorou-se substancialmente diante das incertezas com o resultado do processo eleitoral (BANCO CENTRAL DO BRASIL, 2002). O prêmio do risco-Brasil medido pelo Emerging Market Bond Index Plus (EMBI+) atingiu o nível mais alto desde o início do Plano Real, chegando a 2.436 pontos em 27 de setembro de 2002. As incertezas se traduziram em saídas de capitais e forte depreciação cambial, com a taxa de câmbio passando de $\mathrm{R}$ \$ 2,54 por dólar no início do mês de junho para $\mathrm{R}$ \$,96 em 22 de outubro de 2002, dias antes do segundo turno das eleições, atingindo o valor mais alto até aquele momento, desde o início do Plano Real. A permanência do câmbio em níveis depreciados elevou as expectativas de inflação para o ano seguinte, levando-a a atingir 5,85\% ao ano. Diante dessa situação o Copom elevou a meta para a taxa Selic, situando-a em $21 \%$ ao ano. Posteriormente, em dezembro, as expectativas de mercado para a inflação em 2003 atingiram o patamar de $11 \%$ ao ano, levando à reação da Autoridade Monetária. Dessa forma, a Selic foi novamente elevada fechando o ano de 2002 em $25 \%$ ao ano, patamar que não era observado desde o episódio da desvalorização cambial ocorrido em 1999. O efeito da depreciação cambial sobre os preços internos levou ao descumprimento da meta de inflação para o ano de 2002. A inflação medida pelo IPCA fechou o ano de 2002 com uma variação de $12,53 \%$ contra uma meta de 3,5\% com 2 pontos percentuais de intervalo de tolerância.

$\mathrm{O}$ aumento na taxa de juros Selic foi inferior ao aumento nas expectativas de inflação. $\mathrm{Na}$ avaliação de Blanchard (2004), o Banco Central agiu corretamente ao permitir a redução das taxas de juros reais. Na opinião do autor, o aumento nas taxas de juros reais, no ambiente de incertezas em que se encontrava a economia brasileira, provavelmente teria efeitos inversos aos esperados, levando ao aumento do risco de default, seguido de maior depreciação cambial e aumento da taxa de inflação. Nesse caso, o instrumento correto para conter as expectativas inflacionárias, de acordo com Blanchard (2004) deveria ser a política fiscal e não a taxa de juros real. A redução do grau de endividamento da economia através da ação fiscal conduziria à redução do risco de default, abrindo espaço para a atuação da política monetária.

Com o fim do pleito eleitoral, houve uma ligeira melhora nas expectativas. O risco-país medido pelo EMBI+, que atingira 2.436 pontos em setembro, alcançou 1.824 pontos no dia 28 de outubro, um dia após o resultado da eleição e fechou o ano de 2002 em 1.446 pontos. A 
taxa de câmbio, por sua vez, que chegara a R \$3,96/US\$ na semana que antecedeu o segundo turno das eleições, fechou o último dia do ano de $2002 \mathrm{em} \mathrm{R}$ 3,53/US\$.

A melhora nas expectativas estava em parte associada ao início do inédito processo de transição de governo proposto pelo Presidente Fernando Henrique Cardoso e, em parte, às escolhas do novo Presidente eleito para compor a equipe econômica. De acordo com Giambiagi (2004) Lula surpreendeu ao indicar Antonio Palocci para o Ministério da Fazenda, visto pelo mercado como um adepto da continuação da política de superávits primários. Para o Banco Central, o Presidente eleito também surpreendeu ao indicar o nome de Henrique Meirelles, ex-presidente mundial do Bank Boston.

A última estimativa do crescimento real do PIB divulgada pelo Governo em dezembro de 2002, apontava para um crescimento anual efetivo de 1,60\%, bastante abaixo da previsão de $3,5 \%$ que fora considerada tanto na LDO quanto na LOA e inferior, inclusive, à previsão de 2,5\% que fundamentou o Decreto 4.120/2002 de Programação Orçamentária e Financeira.

Apesar da crise de confiança que acometeu a economia brasileira e do crescimento efetivo inferior ao previsto, as metas fiscais fixadas no acordo com o FMI foram plenamente cumpridas em 2002. O setor público consolidado fechou o ano com um superávit primário de $\mathrm{R} \$ 52,4$ bilhões, equivalente a 3,91\% do PIB, superior a meta de $\mathrm{R} \$ 50,3$ bilhões $(3,88 \%)$ estabelecida no Memorando Técnico de Entendimento com o FMI. Esse resultado foi possível em função do foco total do Governo no cumprimento das metas fiscais. O Governo realizou a execução orçamentária fazendo uso constante do mecanismo de limitação e bloqueio das despesas discricionárias autorizadas na Lei Orçamentária. Em relação à dívida líquida do setor público (DLSP), após alcançar 62,5\% do PIB no mês de setembro de 2002, a dívida declinou para 55,89\% do PIB ao final do ano, alcançando R\$ 881,1 bilhões. Apesar da queda, em função da depreciação do real, a DLSP fechou 2002 com um valor superior à meta de R \$ 830 bilhões estipulada no Memorando Técnico de Entendimentos com o FMI.

Além do mecanismo de contingenciamento de despesas, duas outras ações adotadas pelo Governo permitiram incrementar o volume de arrecadação com receitas extras que não estavam previstas no orçamento. As Medidas Provisórias n. 38 de 14 de maio de 2002 e n. 66 de 28 de agosto permitiram, entre outras coisas, o parcelamento de débitos tributários federais de Estados, do Distrito Federal, de Municípios, empresas públicas e privadas em processo de 
falência ou de liquidação, o pagamento de débitos em atraso dos fundos de previdência e o parcelamento da contribuição para o Programa de Formação do Patrimônio do Servidor Público (Pasep). Com essas medidas, a expectativa de arrecadação ficou acima das despesas programadas, em valor suficiente para o cumprimento da meta fiscal estabelecida para 2002 (BANCO CENTRAL DO BRASIL, 2002). Dessa forma, a melhora na perspectiva de arrecadação, ao longo do segundo semestre, permitiu restabelecer parte das dotações cujos empenhos e movimentação financeira haviam sido limitados. No entanto, apenas parte pequena dos recursos contingenciados foram liberados conforme podemos verificar na Tabela 2 abaixo.

Tabela 7 - Contingenciamento das Despesas Discricionárias do Poder Executivo - R\$ milhões

\begin{tabular}{llll}
\hline Decretos & Ação & $\begin{array}{l}\text { Movimentação e } \\
\text { Empenho }\end{array}$ & Pagamento \\
\hline Dec. 4.120/02 & Contingenciamento & $12.446,10$ & $10.696,10$ \\
Dec. 4.309/02 & Contingenciamento & $1.547,50$ & $3.966,90$ \\
Dec. 4.369/02 & Liberação & $(1.225,00)$ & $(1.535,00)$ \\
Dec. 4.415/02 & Liberação & $(500,00)$ & $(1.577,00)$ \\
Dec. 4.470/02 & Liberação & $(1.242,00)$ & $(1.572,50)$ \\
Dec. 4.512/02 & Liberação & $(500,00)$ & $(400,00)$ \\
Dec. 4.546/02 & Liberação & $(385,00)$ \\
\hline Contingenciamento das Despesas & $10.526,6$ & $9.193,5$
\end{tabular}

O período de tempo relativo aos dois mandatos do Presidente Lula pode ser dividido em três subperíodos de acordo com o comportamento do desvio de previsão entre a taxa de crescimento real esperada do PIB e a taxa de crescimento real efetiva.

O primeiro subperíodo refere-se ao primeiro ano do Governo Lula em 2003, no qual o novo Presidente assumiu e precisou lidar com os efeitos remanescentes da crise de confiança que atingira a economia em 2002. O segundo subperíodo compreende os anos de 2004 a 2007 e refere-se ao período no qual o desvio de previsão do PIB foi positivo, indicando que a taxa efetiva de crescimento real do PIB superou, em média, a taxa de crescimento esperada. Por fim, o último subperíodo compreende os anos de 2009 e 2010 e diz respeito ao período no 
qual as expectativas do Governo de crescimento real do PIB superaram o crescimento efetivo, gerando um desvio de previsão negativo na média dos dois anos. A Tabela 3 a seguir apresenta o desvio de previsão médio dos três subperíodos.

Tabela 8 - Desvio de Previsão do Crescimento Real do PIB - 2003 a 2010

\begin{tabular}{|c|c|c|c|c|c|c|}
\hline Ano & $\begin{array}{c}\% \\
\text { Previsto } \\
\text { LDO }\end{array}$ & $\begin{array}{c}\% \\
\text { Previsto } \\
\text { LOA }\end{array}$ & $\begin{array}{l}\text { \% Realizado } \\
{\text { (tempo-real })^{11}}^{\text {tempon }}\end{array}$ & $\begin{array}{c}\% \text { Realizado } \\
\left(_{(\text {dados revistos })^{12}}\right.\end{array}$ & $\begin{array}{l}\text { Desvio de Previsão }{ }^{13} \\
\text { (LOA - dado revisto) }\end{array}$ & $\begin{array}{l}\text { Desvio de } \\
\text { Previsão } \\
\text { Médio do } \\
\text { Período }\end{array}$ \\
\hline 2003 & 4 & 3 & 0,3 & 1,14 & $-1,86$ & $-1,86$ \\
\hline 2004 & 3,5 & 4 & 5 & 5,76 & 1,76 & \multirow{5}{*}{0,37} \\
\hline 2005 & 4 & 4 & 2,6 & 3,2 & $-0,8$ & \\
\hline 2006 & 4,5 & 4,5 & 3 & 3,96 & $-0,54$ & \\
\hline 2007 & 4,75 & 4,75 & 5,2 & 6,07 & 1,32 & \\
\hline 2008 & 5 & 5 & 5,61 & 5,09 & 0,09 & \\
\hline 2009 & 5 & 3,5 & 0,21 & $-0,13$ & $-3,63$ & \multirow{2}{*}{$-0,55$} \\
\hline 2010 & 4,5 & 5 & 7,32 & 7,53 & 2,53 & \\
\hline \multicolumn{7}{|c|}{$\begin{array}{l}\text { FONTES: LDO - Anexo de Metas Fiscais, Secretaria do Tesouro Nacional - Relatório de Cumprimento das } \\
\text { Metas Fiscais, Banco Central do Brasil. Elaboração Própria. } \\
{ }^{11} \text { Dados em tempo real: referem-se a última estimativa do PIB divulgada pelo Banco Central nos Relatórios de } \\
\text { Inflação dos meses de dezembro de cada ano. } \\
{ }^{12} \text { Dados revistos: última correção do PIB realizada pelo IBGE. Dados coletados em novembro/2015. } \\
{ }^{13} \text { Desvio de Previsão: Valores previstos na LOA - Valores efetivos realizados (revistos). }\end{array}$} \\
\hline
\end{tabular}

Pela Tabela 3, podemos observar que no primeiro ano do novo Presidente, a taxa de crescimento real ficou bastante abaixo da taxa esperada para aquele ano, gerando um desvio de previsão negativo de 1,86 pontos percentuais em comparação com a LOA e 2,86 em comparação com a previsão contida na LDO. Este desvio foi fruto do otimismo presente nos parâmetros macroeconômicos que embasaram a Lei de Diretrizes Orçamentárias e a Lei Orçamentária Anual de 2003, cujas propostas foram preparadas pelo Governo anterior.

O Projeto de Lei de Diretrizes Orçamentárias para 2003 foi encaminhado ao Congresso em abril de 2002, quando as perspectivas do Governo para a economia ainda eram favoráveis. Nenhum dos eventos negativos ocorridos ao longo de 2002 e que impactariam no ano seguinte foi antecipado no PLDO 2003. Os Anexos de Metas e Riscos Fiscais não fazem sequer uma única menção à possibilidade de reversão das expectativas em função do período eleitoral que estava a caminho. 
O Congresso aprovou a LDO mantendo o mesmo cenário otimista de ausência de choques negativos da proposta original (Tabela 3). Entretanto, como vimos anteriormente, no mês de junho de 2002, o Governo elevou as metas de superávit primário de 3,5\% para 3,75\% para o ano de 2002 para lidar com a deterioração das condições econômicas que se verificou no segundo trimestre do ano. Diante desse fato, o Congresso decidiu incluir na LDO 2003 o aumento do superávit anunciado pelo Executivo, estendendo a nova meta para o Governo que assumiria no ano seguinte.

Segundo o relatório final da CMO, os membros da comissão que analisaram o PLDO consideraram a possibilidade de que as projeções macroeconômicas utilizadas pelo Executivo para embasar a proposta estivessem desatualizadas, em função das mudanças que estavam acontecendo no cenário econômico naquele momento. Por esse motivo, os membros da Comissão consideraram a oportunidade de revisar o Anexo de Metas Fiscais da LDO e, em consequência, a meta de superávit primário para 2003. Alguns parlamentares também cogitaram a ideia de flexibilizar a meta de superávit primário para atenuar a rigidez imposta pela LDO ao novo governo que assumiria em 2003. Mas, apesar das considerações dos parlamentares, na falta de indicadores mais confiáveis para 2003, a CMO optou por encaminhar o PLDO para votação mantendo as metas, projeções e expectativas inalteradas.

Tabela 9 - Variáveis Macroeconômicas Projetadas - 2003

\begin{tabular}{lccccc}
\hline & $\begin{array}{c}\text { Var. } \\
\text { Veal PIB }\end{array}$ & $\begin{array}{c}\text { IGP-DI } \\
\text { (acum. ano) }\end{array}$ & $\begin{array}{c}\text { Câmbio } \\
\text { R\$/US\$ } \\
\text { (dezembro) }\end{array}$ & $\begin{array}{c}\text { Selic } \\
\text { média } \\
\text { anual }\end{array}$ & $\begin{array}{c}\text { IPCA } \\
\text { acum. ano }\end{array}$ \\
\hline PLDO e LDO & $4,0 \%$ & $4,0 \%$ & 2,42 & $12,84 \%$ & $7,67 \%$ \\
PLOA e LOA & $3,0 \%$ & $6,0 \%$ & 2,90 & $16,26 \%$ & $4,0 \%$ \\
Dec. 4.591-10.02.03 & $2,8 \%$ & $12 \%$ & 3,24 & $22,17 \%$ & $8,50 \%$ \\
Dec. 4.708-28.05.03 & $2,25 \%$ & $14,5 \%$ & 3,43 & $23,66 \%$ & $10,8 \%$ \\
Dec. 4.847-25.09.03 & $0,98 \%$ & $8,0 \%$ & 3,16 & $23,79 \%$ & $9,5 \%$ \\
Dec. 4.894-25.11.03 e & $0,4 \%$ & $8,5 \%$ & 3,09 & $23,47 \%$ & $9,7 \%$ \\
posteriores/ & $0,3 \%$ & $7,67 \%$ & 2,89 & $23,37 \%$ & $9,3 \%$ \\
Realizado/ & & & & & \\
\hline
\end{tabular}

FONTE: LDO 2003 e PLOA 2003.

$I^{1}$ Decretos 4.913 de $11.12 .03,4.926$ de 22.12 .03 e 4.938 de 29.12 .03

$l^{2}$ Última estimativa do valor do PIB disponível em 2003

Em agosto de 2002, quando o Projeto de Lei Orçamentária Anual para 2003 foi enviado ao Congresso para apreciação, o cenário inicialmente favorável já estava se esvaindo e o Brasil negociava um novo empréstimo junto ao FMI. Por conta desse novo empréstimo, o PLOA reforçou a necessidade de obter superávits primários consistentes com a redução da relação 
dívida/PIB, de modo que a meta de superávit primário foi mantida em 3,75\% do PIB, de acordo com as metas definidas na LDO.

Embora o PLOA tenha projetado uma piora em relação ao cenário macroeconômico utilizado na preparação da LDO, refletindo as perspectivas econômicas vigentes em agosto, as expectativas quanto ao desempenho da economia em 2003 ainda eram bastante otimistas (Tabela 9), sobretudo quando comparadas às expectativas do mercado financeiro que indicavam um crescimento real esperado de $2 \%$ para 2003, de acordo com o Boletim Focus do Banco Central de 06 de dezembro de 2002.

Ao avaliar o Projeto de Lei Orçamentária, o Congresso manteve a mesma expectativa de crescimento real, de juros e de câmbio da proposta original. Porém, elevou as expectativas de inflação. Adicionalmente, as receitas e despesas previstas também foram elevadas. O acréscimo na expectativa de arrecadação, de $\mathrm{R} \$ 328,0$ para $\mathrm{R} \$ 352,8$ bilhões ocorreu, principalmente, em função da atualização da média de preços tanto em 2002 quanto em 2003. Além da revisão das expectativas de inflação, contribuíram para esse acréscimo as alterações na legislação tributária que não estavam consideradas na PLOA por terem ocorrido no segundo semestre de 2002, tais como a prorrogação para 2003 da alíquota do IRPF em 27,5\%, que inicialmente voltaria para $25 \%$ em 31 de dezembro de 2002. Em relação ao acréscimo nas despesas, a maior parte do acréscimo foi direcionada para o atendimento de emendas individuais e coletivas, incluindo o aumento do investimento que passou de $\mathrm{R} \$ 7.351,00$ milhões para R $\$ 13.695,00$, e para cobrir as despesas decorrentes de aumento do salário mínimo.

Em 2003, a economia brasileira evoluiu de forma distinta nos dois semestres do ano. No primeiro semestre, prevaleceram as dúvidas iniciadas no ano anterior quanto ao processo de transição política. Além disso, no âmbito externo, permaneciam as incertezas quanto à recuperação da economia mundial e quanto aos possíveis desdobramentos da Guerra no Iraque. Nesse ambiente, ocorreu elevação do risco-país, redução da disponibilidade de recursos externos seguidos de depreciação da taxa de câmbio e elevação da taxa de inflação.

A lei orçamentária foi sancionada em janeiro de 2003 pelo novo Presidente, sem cortes nas previsões de receitas ou despesas. Entretanto, em fevereiro, por ocasião da programação orçamentária (Decreto n. 4.591/2003), os parâmetros macroeconômicos foram revistos e 
passaram a indicar deterioração no cenário esperado para 2003 (Tabela 9), resultando em queda na projeção de crescimento do PIB. Conforme destacado por Giambiagi (2004), o novo Presidente precisava eliminar as desconfianças e demonstrar inequivocamente seu comprometimento com o tripé formado por metas de inflação, metas de superávit primário e câmbio flutuante. Dessa maneira, em resposta à deterioração das expectativas e para garantir seu compromisso com a trajetória declinante da relação dívida/PIB, uma série de medidas foi adotada, entre elas, destaca-se a Elevação da meta de superávit primário do setor público consolidado para 2003 de 3,75\% para 4,25\% do PIB, haja vista que a meta prevista na LDO não era mais suficiente para manter a estabilidade da relação dívida/PIB.

Com o objetivo de adequar o orçamento à nova meta de superávit primário, o Governo promoveu, através do Decreto 4.591/2002, um contingenciamento de R $\$ 14,1$ bilhões nos limites de pagamento, movimentação e empenho que estavam previstos na LOA. $O$ contingenciamento não foi realizado em resposta a uma frustração na arrecadação, haja vista que a arrecadação do primeiro bimestre superou o valor previsto para o período. Ao contrário, o contingenciamento ocorreu para garantir que a nova meta de superávit primário fosse alcançada face ao aumento nas despesas obrigatórias. A respeito desse contingenciamento, Silva (2004) sugere que essa medida tenha sido inadequada, até mesmo ilegal, uma vez que a LRF (Art. $9^{\circ}$ ) contempla a hipótese de limitação de empenho e movimentação financeira quando, ao final de um bimestre, verificar-se que a realização da receita não poderá comportar o cumprimento das metas de resultado primário ou nominal estabelecidas na LDO. Ou seja, o contingenciamento realizado em fevereiro de 2003 não foi em resposta à frustração na arrecadação, conforme estabelece a LRF.

Do lado monetário, a variação acumulada em 12 meses do IPCA atingiu 14,5\% em janeiro, projetando uma inflação anualizada de $30,6 \%$ para 2003. No primeiro trimestre do ano, o IPCA atingiu 5,13\%. Em resposta, o Banco Central elevou a meta para a taxa Selic para $25,5 \%$ e $26,5 \%$ ao ano em janeiro e fevereiro de 2003, respectivamente, mantendo-a nesse patamar até o mês de junho. Adicionalmente, a alíquota de recolhimento compulsório sob depósitos à vista foi elevada de $45 \%$ para $60 \%$, visando reduzir os recursos disponíveis para retenção de moeda estrangeira no curto prazo. Outra medida significativa adotada pelo Banco Central foi a elevação da meta de inflação a ser perseguida em 2003 de $4 \%$ para 8,5\% e de $5,5 \%$ em 2004. Caso a meta de inflação fosse mantida em 4\%, além das evidências de que não 
seria cumprida, o Banco Central teria que impor uma rigidez ainda maior na política monetária, com perdas mais expressivas em termos de crescimento do produto.

Além das medidas referidas, o Governo submeteu à apreciação do Congresso duas Propostas de Emenda Constitucional (PEC's) relativas à Reforma da Previdência e à Reforma Tributária. A resposta do mercado aos sinais enviados pelo novo governo de que manteria o compromisso com a responsabilidade fiscal e com a estabilidade da moeda começou a aparecer através do recuo da cotação do dólar de $\mathrm{R}$ \$ 3,59 em fevereiro de 2003 para $\mathrm{R}$ \$ 2,95 no mês de maio e através da queda no risco-país medido pelo EMBI+ que passou de 1.322 pontos no dia 10 de fevereiro, dia da publicação do Decreto que elevou a meta de superávit primário, para 802 pontos no dia 28 de maio de 2003.

Conjuntamente com a apreciação cambial, a taxa de inflação medida pelo IPCA entrou em uma trajetória declinante, ocorrendo, inclusive, deflação de $0,15 \%$ no mês de junho de 2003. Paralelamente, as expectativas de inflação começaram a convergir em direção às metas fixadas para 2003 e 2004. Diante deste quadro, a política monetária passou a ser flexibilizada permitindo uma redução gradativa da taxa Selic, que alcançou 16,5\% ao ano no mês de dezembro. O Banco Central também retornou a alíquota de recolhimento compulsório sob depósitos à vista para o nível anterior à elevação efetuada em fevereiro. No entanto, enquanto as projeções de inflação, de juros e de câmbio melhoravam a partir do segundo semestre, as expectativas em relação ao PIB continuavam a indicar desaceleração da economia (Tabela 9).

Não obstante o baixo desempenho do PIB, o Setor Público Consolidado conseguiu cumprir a meta de superávit primário em 2003. Na verdade, o superávit alcançado pelo setor público consolidado foi de 4,32\% do PIB, superando a meta de 4,25\%. O Governo Central contribuiu com um superávit de $2,56 \%$ do PIB, enquanto as estatais contribuíram com $0,89 \%$ do PIB. De acordo com o discurso oficial, o resultado alcançado pelo Governo Central deve-se, em grande parte, a uma forte contração dos gastos realizada ao longo de 2003. A despesa total, líquida das transferências para os Estados e Municípios, representou 16,92\% do PIB contra 17,01\% em 2002 (BANCO CENTRAL DO BRASIL, 2003). Como podemos verificar na Tabela 10 a seguir, a despesa total paga em 2003 foi inferior à previsão contida no orçamento. 
Tabela 10 - Comparativo Receita e Despesa Prevista LDO, PLOA, LOA e Decretos de Programação Financeira

\begin{tabular}{lcc}
\hline Discriminação & Receita Primária Total* & Despesa PrimáriaTotal** \\
\hline LDO & 321,30 & 242,00 \\
PLOA & 329,60 & 248,10 \\
LOA & 354,40 & 266,00 \\
Dec. $4.591 / 03-10.02 .2003$ & 357,70 & 262,40 \\
Dec. $4.708 / 03-28.05 .2003$ & 363,30 & 265,60 \\
Dec. $4.847 / 03-25.09 .2003$ & 357,90 & 263,90 \\
Dec. $4.894 / 03-25.11 .2003$ & 358,50 & 264,50 \\
Dec. 4.913/03 - 11.12.2003 & 359,30 & 265,20 \\
Realizado 11 & 360,30 & 263,80 \\
\hline FONTE: Secretaria do Tesouro Nacional, Relatório de Avaliação Quadrimestral, Lei Orçamentária Anual 2003 e \\
PLOA 2003. & \\
11 Valores divulgados em dezembro de 2003 no Resultado do Tesouro Nacional (STN/MF) e na Nota para \\
Imprensa - Política Fiscal (BCB/MF) \\
* Inclui a Receita Administrada líquida de restituições e incentivos fiscais, a Receita não Administrada, \\
Contribuições ao FGTS e Arrecadação Líquida da Previdência. \\
** Inclui Despesas com Pessoal e Encargos Pessoais, Contribuições ao FGTS, Despesas Discricionárias, \\
Despesas Não Discricionárias e Benefícios da Previdência.
\end{tabular}

No entanto, devemos alertar para o fato de que o superávit fiscal de 2003 foi obtido em contrapartida à elevação do saldo da conta Restos a Pagar (RAP). De acordo com dados retirados das séries estatísticas da Secretaria do Tesouro Nacional, o saldo de Restos a Pagar inscritos em 2003 atingiu $\mathrm{R} \$ 33.5$ bilhões, contra $\mathrm{R} \$ 21$ bilhões em 2002 . O total de restos a pagar processados passou de $\mathrm{R} \$ 6.5$ bilhões em 2002 para $\mathrm{R} \$ 9.7$ bilhões em 2003. O saldo de RAP não-processados teve um aumento ainda mais significativo de R $\$ 14.5$ bilhões em 2002 para $R \$ 23.8$ bilhões em 2003. Isso significa que parte do superávit fiscal alcançado em 2003 decorreu do adiamento de despesas e não de uma redução efetiva de gastos. O subterfúgio de recorrer aos restos a pagar para, contabilmente, cumprir com o superávit fiscal foi adotado em outras oportunidades ao longo dos anos analisados nessa tese. O assunto será resgatado mais adiante.

Em relação à arrecadação, a Tabela 10 mostra que a Receita Total superou a previsão da Receita contida tanto na LDO quanto na LOA. Excluindo-se as receitas atípicas, que não tendem a se repetir, a arrecadação de impostos e contribuições federais em 2003 foi 3,3\% maior em termos reais do que em 2002 (BANCO CENTRAL DO BRASIL, 2004).

Se por um lado, o crescimento econômico menor que o previsto prejudicou a arrecadação, por outro, a taxa de inflação e a taxa de juros acima da previsão inicial contribuíram para elevá-la. A arrecadação também foi favorecida por mudanças na alíquota de impostos, com destaque para a prorrogação da alíquota de 27,5\% do Imposto de Renda Pessoa Física que foi aprovada 
em dezembro de 2002 e não estava prevista na LDO 2003. Contudo, o que mais favoreceu a arrecadação em 2003 foi o desempenho do setor de petróleo. Em 2003, o lucro da Petrobrás foi $120 \%$ maior do que o ocorrido em 2002 (CONGRESSO NACIONAL, 2007). Contribuíram para esse resultado a depreciação do real e a elevação do preço do barril de petróleo no mercado internacional. A elevação acima do esperado nos lucros da Petrobrás elevou a arrecadação do Imposto de Renda Pessoa Jurídica (IRPJ), a Contribuição sobre o Lucro Líquido (CSLL) e a receita da cota-parte de compensações financeiras (royalties e participação especial) pela exploração de petróleo, além de ter elevado os dividendos recebidos pelo Governo Federal.

Além do êxito na contração fiscal que garantiu o cumprimento da meta de superávit, o Presidente Lula conseguiu aprovar no Congresso, em tempo recorde, ainda no seu primeiro ano de mandato, duas importantes reformas: a Reforma da Previdência e a Reforma Tributária. Em 30 de abril de 2003, o Presidente Lula encaminhou ao Congresso a Proposta de Emenda Constitucional (EC) n. 40. que instituía a Reforma da Previdência e a Proposta de Emenda Constitucional n. 41 que instituía a Reforma Tributária. A meta do Presidente era aprovar as reformas ainda em 2003, especialmente a Tributária que garantiria receitas já para o ano seguinte. Acreditava-se que essas reformas ajudariam a mudar a percepção dos investidores estrangeiros em relação ao Brasil e seria um importante passo na transformação do país em "grau de investimento" (GIAMBIAGI, 2005). Antes mesmo do final do ano, ambas as propostas já estavam aprovadas pelo Congresso.

A reforma tributária visava 4 objetivos principais: a) a uniformização entre os Estados da legislação do Imposto sobre a Circulação de Mercadorias e Serviços (ICMS); b) a prorrogação da Desvinculação de Receitas da União (DRU) que venceria em dezembro de 2003 e visava reduzir a quantidade de recursos que o Governo era obrigado a gastar, permitindo ao Governo remanejar recursos e aproveitar receitas para a geração de superávit primário; c) renovar a CPMF para além de 2003; d) simplificar a cobrança da Contribuição para o Financiamento da Seguridade Social (Cofins) (GIAMBIAGI, 2005).

Em relação à reforma da Previdência, o foco foi a Previdência do setor público. A reforma sugerida recuperava propostas do governo anterior que não obtiveram êxito na aprovação, especialmente por conta da resistência de partidos de oposição, cujo próprio Partido dos Trabalhadores (PT) era o principal representante. As mudanças propostas propunham, entre 
outras coisas, fixar um teto e aumentar a idade mínima para a aposentadoria, definir regras mais rígidas para a obtenção de aposentadoria integral, reduzir os valores de pensões, definir um teto para os salários dos servidores públicos e estabelecer a contribuição dos inativos e pensionistas.

O Presidente Lula conseguiu articular o apoio político necessário para a aprovação das reformas. ${ }^{53}$ Contou também com o apoio dos governadores estaduais que tinham interesse na aprovação da Reforma Previdenciária para minimizar os problemas nas previdências estaduais. Contudo, a resistência maior na aprovação das propostas veio de dentro do próprio partido do Presidente. Alguns membros do Partido dos Trabalhadores se opuseram fortemente à adesão do PT às reformas de cunho neoliberais que contrariavam a ideologia de esquerda que sempre fora defendida pelo partido. Quando estava na oposição, o PT era o principal crítico às reformas estruturais e, por vezes, conseguiu impedir que reformas mais profundas fossem realizadas. Em 2003, no entanto, o PT não aceitou a atitude dos membros que se rebelaram contra as propostas sugeridas pelo Governo e os expulsou do partido por indisciplina e infidelidade partidária.

No final de 2003, um novo acordo de aproximadamente US\$ 14 bilhões foi firmado com o FMI, sendo US\$ 8 bilhões referentes à última parcela do acordo de 2002 que ainda não havia sido utilizada e mais US\$ 6 bilhões extras. O novo acordo estendeu o acordo anterior em mais 15 meses, de modo que os desembolsos poderiam ser realizados até o ano de 2007. Segundo declarações do Ministro da Fazenda Antonio Palocci na imprensa, a renovação do acordo ocorria em caráter preventivo, o governo não tinha intenção em sacar os recursos, mas garantir uma espécie de apólice de seguro contra eventuais choques externos (BRASIL, 2003).

Por fim, no que se refere à análise dos desvios de previsão do orçamento, as variáveis macroeconômicas previstas na fase de planejamento do orçamento 2003 (LDO e LOA) ficaram significativamente distantes dos valores realizados (Tabela 9). O mesmo ocorreu com a Receita e a Despesa Primárias estimadas (Tabela 10). A distância entre o valor realizado e o valor estimado é ainda maior, quanto maior o horizonte de previsão considerado, ou seja, os

\footnotetext{
${ }^{53}$ De acordo com o Supremo Tribunal Federal houve compra de votos parlamentares e de apoio político para aprovar projetos de interesse do Executivo no Congresso no primeiro mandato do Governo Lula (Ação Penal 470). O episódio ficou conhecido como Mensalão e foi revelado em 2005, resultando em CPI no Congresso Nacional e em diversas condenações, incluindo parlamentares e pessoas ligadas ao Governo.
} 
maiores desvios são observados entre os valores previstos na LDO e PLOA quando comparados aos realizados. Ao longo do ano, as revisões que o Governo fez nos parâmetros e na arrecadação estimada, reduziu esse desvio, mas não o eliminou.

No PLDO 2004, o primeiro elaborado sob a administração do Presidente Lula, é notório o compromisso anunciado pelo Governo com o tripé macroeconômico formado por metas inflacionárias, câmbio flutuante e responsabilidade fiscal. De acordo com a análise contida no PLDO, o compromisso com a coordenação e a transparência das políticas monetária e fiscal, permitiria reduzir a inflação, reduzir a taxa real de juro, a volatilidade cambial e aumentar a poupança pública, abrindo um horizonte de estabilidade duradoura.

O PLDO foi encaminhado ao Congresso em abril de 2003 com projeções fundamentadas pela expectativa de recuperação do crescimento econômico conjugada com reversão da inflação. A confiança na recuperação da economia também estava sendo reforçada pelo desempenho do setor externo. A evolução do superávit comercial desde 2002 estava contribuindo para reduzir o déficit em conta corrente do balanço de pagamentos, diminuindo a vulnerabilidade externa da economia. Esperava-se que o maior fluxo de divisas contribuisse para valorizar o real e, somado aos superávits primários, permitisse reduzir o endividamento líquido da União.

As projeções constantes no PLDO foram elaboradas com base nesse cenário otimista, que não considerava a hipótese de ocorrência de choques adversos, além de supor preços em queda e relaxamento da política monetária. Dessa forma, o PLDO previu um crescimento real do PIB da ordem de 3,5\% para o ano de 2004, 4,0\% para 2005 e 4,50\% em 2006. Adicionalmente, o PLDO previu queda na taxa de juros sobre a dívida pública e aumento da taxa de câmbio que deveria atingir $\mathrm{R} \$ 3,56$ por dólar ao final do ano de 2004, $\mathrm{R} \$ 3,70$ no final de 2005 e $\mathrm{R} \$ 3,84$ no fim de 2006. Em relação à inflação, o Anexo de Metas Fiscais não apresentou uma previsão pontual para os índices de preços, tampouco assumiu uma previsão para a taxa de juros Selic. Apenas informou que o cenário considerado levava em conta a "redução da inflação em linha com as diretrizes da política monetária e pela criação de condições macroeconômicas para a queda progressiva das taxas reais de juros.” (BRASIL, 2004, p. 2).

As metas fiscais foram estabelecidas em coerência com o acordo firmado com o FMI e iguais as metas para o ano de 2003, ou seja, o superávit primário do setor público consolidado deveria atingir 4,25\% do PIB em 2004, 2005 e 2006. De acordo com o PLDO 2004, essa meta 
era suficiente para reduzir o endividamento líquido do Setor Público em relação ao PIB de $55,07 \%$ em 2004 para 49,24\% em 2006, ou para 51,43\% se considerados as dívidas em processo de reconhecimento, chamadas de "esqueletos". Os resultados fiscais previstos no PLDO foram projetados contando como certa a aprovação da Reforma da Previdência e da Reforma Tributária encaminhada pelo Executivo para apreciação da Câmara dos Deputados em abril de 2003.

O Congresso aprovou o PLDO sem alterações nas metas fiscais e nos parâmetros macroeconômicos. Entretanto, durante a análise da proposta, a CMO alertou para o fato que em todos os anos após a LRF, a Lei de Diretrizes Orçamentárias foi realizada fundamentada em expectativas de crescimento real excessivamente otimistas que não se realizaram em nenhum dos anos. O documento afirmava que a frustração em termos de crescimento é danosa para as contas públicas, pois as receitas crescem menos que o esperado e as despesas tendem a aumentar, especialmente aquelas de natureza social (CMO, 2003).

A proposta orçamentária para 2004 foi encaminhada ao Congresso no mês de agosto de 2003. Naquele momento, a conjuntura econômica era mais favorável do que a encontrada no início de 2003. A economia dava sinais de recuperação, com as expectativas de inflação convergindo em direção às metas fixadas para 2003 e 2004. As exportações seguiam em trajetória de crescimento, apontando para um novo recorde da balança comercial e para a queda na necessidade de financiamento externo. Refletindo o novo cenário, o risco-país medido pelo EMBI+ seguia tendência de queda e se aproximava dos 700 pontos base, o dólar que havia iniciado o ano de 2003 cotado a $R$ \$ 3,52, caiu para $R$ \$ 3,00 no início do mês de agosto e seguia tendência de queda. Ao mesmo tempo, o Banco Central havia começado a flexibilizar gradualmente a política monetária e a taxa Selic, que no mês de fevereiro de 2003 atingira $26,5 \%$ ao ano, caiu para $22 \%$ na reunião do COPOM do mês de agosto.

Com esse cenário mais favorável como pano de fundo, a proposta orçamentária manteve a mesma previsão de crescimento real do PIB de 3,5\% que foi utilizada na elaboração da LDO. Em relação à inflação, era esperada a convergência do IPCA para a meta de 5,5\%. Ao mesmo tempo, esperava-se queda na taxa de juros Selic, que deveria atingir 15,2\% na média anual, e uma taxa de câmbio média de $\mathrm{R} \$ 3,40$ por dólar. 
$\mathrm{O}$ relatório preliminar e o relatório final da $\mathrm{CMO}$, que analisaram o projeto de lei orçamentária, apresentaram um tom bastante diferente do relatório que aprovou a LDO. Enquanto este último mostrou-se preocupado com o frequente otimismo do Executivo em relação às expectativas de crescimento, os relatórios relativos à PLOA reforçaram o viés otimista da proposta do Executivo. Na verdade, a lei orçamentária aprovada pelo Congresso foi além, fundamentando-se em expectativas ainda mais otimistas do que a proposta original. Adicionalmente, ambos os relatórios deixaram claro a confiança e o apoio à condução da política econômica realizada pelo Executivo. Essa confiança fica evidente na seguinte citação extraída do Relatório Preliminar da CMO: “A proposta orçamentária para 2004 é reflexo desse esforço bem sucedido do Poder Executivo, uma vez que apresenta indicadores macroeconômicos melhores do que os que valeram para o início deste ano. A proposta reflete também a continuidade do esforço fiscal para manter a dívida pública brasileira controlada" (CMO, 2003, p. 4).

O cenário macroeconômico adotado na lei orçamentária aprovada pelo Congresso previa a retomada do crescimento a partir de 2004. A expectativa de 3,50\% de crescimento real do PIB contida na PLOA foi elevada para 4,00\% na lei aprovada. O cenário adotado pelo Congresso também previu preços dentro dos limites fixados da meta de inflação, rigidez da política monetária e apreciação do real frente ao dólar. Além das condições internas favoráveis, o Relatório Final da CMO contava também com a expectativa de um crescimento mundial superior a 4\%, liderada pelos Estados Unidos e pelos Tigres Asiáticos e também pela Argentina.

Devemos ressaltar que a reestimativa dos parâmetros utilizados para respaldar a decisão da CMO não foi uma ação unilateral do Congresso. A LDO 2004, pela primeira vez, determinou que o Executivo atualizasse até 30 de outubro de 2003 as previsões do conjunto de parâmetros utilizados para a análise da proposta orçamentária. O Congresso julgou necessário que essa atualização passasse a ocorrer, haja vista que a análise e aprovação da LOA ocorrem vários meses após o envio da proposta pelo Executivo. Soma-se a isso o fato de que, com a proximidade do final do ano, acreditava-se que as estimativas para o ano seguinte seriam mais precisas.

Em função da mudança no cenário macroeconômico subjacente à proposta, o Congresso elevou a receita primária total (exceto Previdência) estimada para 2004 de R \$ 308,60 bilhões 
para R \$ 320,90 bilhões. Na verdade, a atualização dos parâmetros macroeconômicos, por si só, não explica a elevação na arrecadação esperada. Ao contrário, conforme apresentado no Relatório Final da CMO, a atualização de alguns parâmetros teria um efeito redutor da arrecadação, haja vista que menor expectativa de inflação e menor taxa de câmbio tendem gerar perdas de receitas de tributos, haja vista que a queda nas estimativas destes parâmetros afetam as bases tributáveis. Os principais fatores que resultaram em reestimativa das receitas foram: receitas atípicas e a incorporação de receitas que não estavam sendo consideradas na proposta original provenientes da reforma tributária e da previdência (já considerada a noventena, haja vista a aprovação das reformas apenas no final do ano de 2003). A despesa primária total também foi revista, passando de $\mathrm{R} \$ 175,52$ bilhões para $\mathrm{R} \$ 183,32$ bilhões (exceto Previdência). Por fim, o Congresso preservou no orçamento a meta de superávit primário estipulada na LDO, de 4,25\% do PIB para o setor público consolidado, sendo 2,45\% para o Governo Central e 0,70\% para as estatais federais.

\subsubsection{O período de 2004 a 2010}

Passado o primeiro ano do Governo Lula, em que o crescimento econômico real esteve próximo a zero, a economia brasileira experimentou um crescimento real médio de $4,8 \%$ no período de 2004 a 2008. Na média, o crescimento efetivo superou o crescimento previsto, gerando um desvio de previsão positivo de 0,37 pontos percentuais no período (Tabela 8). $\mathrm{O}$ crescimento real acima do esperado repercutiu positivamente na arrecadação e garantiu que as receitas previstas fossem atingidas, gerando um desvio positivo entre as receitas arrecadadas e as receitas previstas. Em 2009, o crescimento econômico real foi negativo em $0.23 \%$ seguindo por um crescimento de $7.57 \%$ em 2010. O desvio de execução da receita acompanhou o desvio do PIB. Em 2009, o desvio entre receita realizada e receita prevista foi negativo e maior do que nos anos anteriores. Em 2010, por sua vez, o desvio foi positivo e também apresentou magnitude elevada em comparação aos demais anos do Governo Lula. Nesta subseção, tentaremos identificar os fatores que contribuíram para esse resultado. Argumentaremos que a previsão fiscal contida na Lei Orçamentária foi otimista, o que fica claro quando analisamos as expectativas a cerca dos efeitos da crise financeira internacional. 
Um conjunto de eventos ocorridos no periodo de 2004 a 2008 favoreceram o crescimento econômico e a arrecadação das receitas do Governo Central. Entre esses eventos, um dos mais relevantes foi a elevação dos preços das commodities internacionais. O índice internacional de preços de commodities (CRB) saiu de 145.61 em janeiro de 2002 para um pico de 422.17 no terceiro bimestre de 2008. Gottlieb e Goldfajn (2014) estimam que em função dessa elevação, a arrecadação do governo cresceu 11.4\%, resultando em um acréscimo de 0.6 pontos percentuais na arrecadação em proporção do PIB.

A transmissão dos efeitos da elevação dos preços das commodities exportadas pelo Brasil sobre a economia e, em especial, sobre os resultados da política fiscal, ocorre por meio de diversos canais. O canal mais direto é o aumento da renda dos exportadores. Com renda mais elevadada os exportadores estão aptos a elevar seu consumo, as empresas exportadoras elevam o investimento, contratam mais trabalhadores e, dessa forma, geram um efeito multiplicador da renda e maior arrecadação de impostos.

Outro importante canal foi a elevação das receitas públicas via recebimento de royalties pela exploração dos recursos naturais (petróleo, minério, gás, etc.) nos três níveis de governo e o aumento da arrecadação proveniente dessa tributação. Além dos royalties, o boom das commodities também elevou a receita com dividendos devido ao maior dinamismo das estatais, em especial a Petrobrás, e das empresas nas quais o Governo detem participação, através do BNDES, como a Vale S.A. (Tabela 11).

Tabela 11 - Evolução Arrecadação Receitas Selecionadas - R\$ bilhões

\begin{tabular}{cccc}
\hline Ano & Dividendos recebidos pela União & Cota-parte & Imposto de Renda \\
\hline 2002 & $3,163.8$ & $7,161.76$ & $78,973.2$ \\
2003 & $3,828.3$ & $10,887.77$ & $83,624.5$ \\
2004 & $4,309.0$ & $12,156.13$ & $92,112.7$ \\
2005 & $4,854.0$ & $15,114.07$ & $115,285.6$ \\
2006 & $9,740.4$ & $18,595.36$ & $125,835.0$ \\
2007 & $6,977.1$ & $17,026.18$ & $148,013.7$ \\
2008 & $13,363.8$ & $25,031.68$ & $179,249.4$ \\
2009 & $26,683.0$ & $19,412.03$ & $178,795.8$ \\
2010 & $22,414.5$ & $24,420.67$ & $194,672.4$ \\
2011 & $19,962.4$ & $29,585.56$ & $235,799.8$ \\
2012 & $28,019.0$ & $34,131.24$ & $246,653.3$ \\
2013 & $17,141.6$ & $36,450.84$ & $272,592.3$ \\
2014 & $18,939.6$ & $39,372.78$ & $285,684.3$ \\
2015 & $12,072.6$ & $28,830.90$ & $300,442.5$ \\
\hline
\end{tabular}

Fonte: Secretaria do Tesouro Nacional, Séries Estatísticas. 
O dinamismo do setor de commodities, em especial o setor de petróleo, contribuiu para elevar o crescimento da economia e aumentar a arrecadação de impostos, tanto os impostos diretos sobre os preços e volume de combustíveis, como o imposto sobre a renda e sobre ganhos de capital (BANCO CENTRAL DO BRASIL, 2006).

O período de 2004 a 2010 também conviveu com a desvalorização do dólar. Na verdade, a desvalorização da moeda americana ocorreu até o fim de 2011. A taxa de câmbio Real/Dólar saiu de R \$ 3.43 em janeiro de 2003, no início do Governo Lula, para R\$ 1.61 em agosto de 2008. Valorizou-se ao final de 2008, atingindo R \$ 2.39/dólar e voltou a desvalorizar-se em seguida, chegando a $\mathrm{R} \$ 1.56$ em julho de 2011, subindo a partir de então. A queda no valor do dólar ocorreu frente às principais moedas internacionais e foram vários os fatores que contribuíram para esse resultado, entre eles, as medidas expansionistas adotadas pelo Federal Reserve em resposta à crise do subprime iniciada em $2007^{54}$. No âmbito nacional, a queda na percepção de risco macroeconômico ocasionada pela adoção de medidas de política econômica coerentes com a manutenção do tripé macroeconômico ${ }^{55}$, vinculado à crescente liquidez internacional e a baixa taxa de juros nos países desenvolvidos, elevou o interesse dos investidores internacionais pelos ativos brasileiros, ocasionando uma crescente entrada de investimento estrangeiro e valorizando o real frente o dólar (BANCO CENTRAL DO BRASIL, 2011).

A entrada de dólares também foi motivada pela melhora nos termos de troca ocorrida entre 2009 e 2011. De acordo com Pastore e Pinotti (2011), após relativa estabilidade entre 2004 e 2008, os termos de troca cresceram aproximadamente 25\% entre 2009 e 2011, aumentando o fluxo de dólares para a economia. O crescente fluxo de dólares elevou o volume de reservas internacionais de US\$ 37.8 bilhões no final de 2002 para US\$ 373.15 bilhões no final de 2012, quando atingiu seu valor máximo. Durante o primeiro mandato do Presidente Lula, a valorização da moeda doméstica frente ao dólar ajudou a ancorar a inflação na medida em que permitiu o aumento das importações e o aumento da oferta de produtos em um contexto de demanda interna crescente. Como resultado, a inflação medida pelo IPCA ao longo do primeiro mandato foi decrescente e, em 2006, pela primeira vez desde o início do Regime de Metas, fechou o ano com uma taxa de inflação acumulada inferior à meta de $4.5 \%$ ao ano.

\footnotetext{
${ }^{54}$ Pastore e Pinotti (2011) apresentam uma descrição desses fatores.

${ }^{55} \mathrm{O}$ índice de Risco-Brasil Embi+ que estava em 1.387 pontos em 02/01/2003, primeiro dia da gestão Lula, atingiu 450 pontos em 02/01/2004 e 192 pontos em 29/12/2006, último dia úlil do primeiro mandato. Em 31/12/2010, final do segundo mandato do Presidente Lula, o Embi+ estava em 189 pontos (IPEADATA).
} 
Por outro lado, o acúmulo de reservas internacionais exigiu um processo de esterilização da moeda doméstica que contribuiu para elevar a dívida interna pública bruta, embora a dívida líquida estivesse em queda (PELLEGRINI, 2011).

Além dos eventos externos, as medidas de políticas econômicas e sociais adotadas pelo Governo foram essenciais para explicar o aumento da arrecadação do período 2004 a 2010. Entre essas medidas estão a criação do crédito consignado em 2003, a expansão dos programas de transferências de renda, em especial o Bolsa Família, além da política de reajuste do salário mínimo em vigor desde 2006 e que permitiu ganhos reais aos trabalhadores e aos aposentados e pensionistas do INSS. ${ }^{56}$

O crédito aumentou de forma expressiva ao longo de todo o Governo Lula tanto no âmbito da pessoa física, quanto jurídica. $\mathrm{O}$ crédito à pessoa física foi estimulado, principalmente, pela criação do consignado em 2003. Entre 2004 e 2008, o aumento da oferta de crédito foi guiada pelos bancos privados, com uso de recursos livres. A partir de 2008, o Governo promoveu a expansão do crédito através dos bancos públicos e de recursos direcionados. O volume de crédito que representava $26 \%$ do PIB em dezembro de 2002, atingiu $45.2 \%$ em dezembro de 2010 (MORA, 2015).

Os ganhos do setor produtor de commodities, a expansão da oferta de crédito, as transferências de renda governamental e os reajustes reais do salário mínimo, ao mesmo tempo em que o Banco Central mantinha o controle da inflação, permitiu o aumento do consumo, com efeitos multiplicador sobre o emprego e renda. De acordo com o Banco Central, o dinamismo do consumo privado, favorecido pela expansão dos mercados de crédito e de trabalho, foi determinante no crescimento econômico observado a partir de 2004 (BANCO CENTRAL DO BRASIL, 2009a). O crescimento real médio ficou em torno de 4\% durante os 8 anos do Governo Lula e a taxa de desemprego medida pelo IBGE nas Regiões Metropolitanas, saiu de $11.20 \%$ em janeiro de 2003 para 5.30\% em dezembro de 2010, acompanhado por um aumento no grau de formalização da mão-de-obra (44\% dos trabalhadores com carteira assinada em proporção da população ocupada no primeiro semestre de 2008, evoluindo para 58\% ao final de 2013, segundo dados da PNAD).

\footnotetext{
${ }^{56}$ A política de reajuste do salário mínimo em vigor desde 2006 tem como base a correção da inflação, medida pelo INPC (Índice Nacional de Preços ao Consumidor) do ano anterior, mais a variação do PIB de dois anos anteriores.
} 
Todos esses fatores citados colaboraram para a elevação da arrecadação. Por sua vez, o maior volume de receitas permitiu sustentar as políticas de transferência de renda e de valorização do salário mínimo, além das despesas correntes e do aumento dos investimentos públicos, mantendo baixos os desvios de execução da receita e da despesa.

Ao longo de todo o primeiro mandato do Presidente Lula, o Governo manteve o clima de otimismo presente nas propostas orçamentárias. A mensagem presidencial que encaminhou a PLOA 2007, e que foi preparada no ano da disputa eleitoral pelo segundo mandato, destacou os ganhos de credibilidade e a estabilidade alcançada com as medidas de política físcal e monetária adotadas pelo Governo, enfatizando também os ganhos sociais. A referida mensagem anunciava o início de um ciclo de crescimento econômico que dizia ser inédito na história brasileira, com inflação baixa, crescimento elevado, saldo positivo em transações correntes e queda no endividamento público.

Com a reeleição do Presidente Lula para o segundo mandato, o clima de otimismo foi mantido. Na mensagem que encaminhou a PLOA 2008, a Balança Comercial foi enaltecida como sendo o principal fator de sustentação dos bons resultados do Balanço de Pagamentos, ao garantir a estabilidade dos superávits em transações correntes. A mensagem referia-se aos saldos comerciais positivos como robustos e promotores de ganhos de produtividade do setor exportador. As expectativas contidas na PLOA sinalizavam com um crescimento mundial de $5,2 \%$ em 2007 e 2008 que continuaria a garantir o financiamento do balanço de pagamentos brasileiro.

A Proposta Orçamentária para 2008 contemplava receitas condicionadas referentes à prorrogação da CPMF (previsão de R 39.3 bilhões de arrecadação) e da DRU (Desvinculação de Receitas da União, R \$ 89.2 bilhões), cuja vigência acabaria em 31/12/2007 caso não fossem prorrogadas pelo Legislativo. Em outubro de 2007, a Câmara aprovou a prorrogação da CPMF até o final de 2011, mas a iniciativa foi derrubada pelo Senado, pondo fim à cobrança da referida contribuição e reduzindo as expectativas de receita contidas na proposta orçamentária. A prorrogação da DRU, por sua vez, foi aprovada até 31/12/2011 por meio da Emenda Constitucional n. 56 de 2007. 
A LOA 2008 foi aprovada com uma previsão de crescimento real de 5\% e inflação medida pelo IPCA de $4.2 \%$ ao ano, abaixo do centro da meta. Ao longo de 2008, no entanto, a taxa de inflação começou a subir e se aproximar do teto da meta de inflação. Em resposta, a taxa de juros que estava mantida em 11,25\% desde setembro de 2007, foi elevada em 2,25 pontos percentuais entre abril e setembro de 2008, permanencendo em $13,75 \%$ ao ano até janeiro de 2009, quando passou a ser reduzida. De acordo com o Banco Central, o aumento nos preços internos foi puxado pelo preço das commodities agrícolas, que reagiu ao maior crescimento mundial e maior demanda internacional por alimentos (BANCO CENTRAL DO BRASIL, 2008). Internamente, o aquecimento da demanda interna acima da oferta criou o ambiente para o repasse dos preços.

Em setembro de 2008, a crise financeira internacional se agravou com a falência do Banco Lehman Brothers, elevando a aversão ao risco e a necessidade dos investidores estrangeiros cobrirem perdas em seus países. Em resposta, houve uma expressiva saída líquida de moeda estrangeira do mercado doméstico nos últimos meses de 2008 e início de 2009, elevando a cotação da moeda americana de $\mathrm{R} \$ 1.61$ em agosto de 2008 para $\mathrm{R}$ \$ 2.39 em média no mês de dezembro do mesmo ano (BANCO CENTRAL DO BRASIL, 2008).

Adicionalmente, os efeitos da desvalorização anterior do dólar, que ocorrera desde 2004 em um contexto de demanda interna aquecida, começaram a aparecer sobre o saldo do balanço de pagamentos. Com a saída de capitais em função da crise financeira externa, o aumento das remessas de lucros e dividendos para o exterior devido ao maior estoque de investimento direto, o aumento no volume de importações e queda no volume exportado em função da redução do crescimento mundial, o saldo em transações correntes tornou-se deficitário após 5 anos de saldos positivos.

Apesar dos eventos negativos ocorridos em 2008, o ano terminou com um crescimento real de $5.6 \%$ (dado em tempo real) acima da expectativa contida na LOA que era de 5\% (e 5.02\% de crescimento real revisto), superávit primário de $4.07 \%$ do PIB, acima da meta de $3.8 \%$, e com receitas e despesas acima dos valores previstos. Adicionalmente, em 2008 o país foi alçado a grau de investimento por duas importantes agências de risco, a Standard \& Poor's em 30 de abril e a Fitch em 29 de maio. 
Apesar de conter ressalvas a respeito da deterioração do saldo em transações correntes, o Projeto de Lei Orçamentária para 2009 continou otimista em relação à melhora na solvência externa do país e com expectativas positivas a respeito da manutenção de ingresso líquido de capitais. A mensagem presidencial que encaminhou o PLOA apostava em um cenário externo relativamente estável, com pequena desaceleração no crescimento mundial e descartava a possibilidade de ocorrência de choques adversos sobre a economia doméstica. A Lei Orçamentária foi aprovada pelo Congresso em dezembro de 2008, quando a crise financeira internacional já havia se intensificado. Por conta desse agravamento da crise, o Congresso reduziu a expectativa de crescimento econômico real para 3.5\% contra os $4.5 \%$ estipulados na proposta do Executivo. Mesmo com essa redução, a taxa de crescimento esperada ainda era superior à taxa de $2.80 \%$ prevista pelo mercado no Boletim Focus. As expectativas em relação à inflação, juros e câmbio estavam em linha com as expectativas de mercado. Com as mudanças nos parâmetros macroeconômicos, as estimativas de receita e de despesa também foram revisadas para baixo (TABELA 12).

Tabela 12 - Evolução dos Parâmetros Macroeconômicos Previstos - 2009

\begin{tabular}{|c|c|c|c|c|c|c|c|c|c|}
\hline Referência & $\begin{array}{c}\text { IPCA } \\
\text { Var. } \\
\text { Acum. }\end{array}$ & $\begin{array}{l}\text { IGP-DI } \\
\text { Var. } \\
\text { Acum. }\end{array}$ & $\begin{array}{c}\text { Câmbio } \\
\text { R\$/US\$ } \\
\text { (dez.) }\end{array}$ & $\begin{array}{l}\text { PIB } \\
\text { Var. } \\
\text { Real }\end{array}$ & $\begin{array}{l}\text { SELIC } \\
\text { Média } \\
\text { a.a. }\end{array}$ & $\begin{array}{c}\text { Massa } \\
\text { Salarial }\end{array}$ & $\begin{array}{l}\text { Petróleo } \\
\text { (Brent - } \\
\text { US\$) }\end{array}$ & Receita & Despesa \\
\hline $\begin{array}{l}\text { PLDO } 2009 \text { - Parâmetro } \\
\text { 17.03.08 }\end{array}$ & 4.5 & 4.57 & 1.81 & 5 & 10.63 & 12.07 & 98.37 & 757.5 & 689.0 \\
\hline $\begin{array}{l}\text { PLOA } 2009 \text { - Parâmetro } \\
10.07 .08\end{array}$ & 4.5 & 5.3 & 1.71 & 4.5 & 13.99 & 14.08 & 111.97 & 808,9 & 606.5 \\
\hline LOA 2009 & 4.5 & 5.8 & 2.04 & 3.5 & 13.57 & 12.95 & 76.37 & 805.3 & 609.7 \\
\hline $\begin{array}{l}\text { Boletim Focus - 28.11.08 } \\
\text { Dec. 6752/09 (28.01.09) } \\
\text { Programaç̃o Financeira }\end{array}$ & $\begin{array}{r}5.25 \\
4.5\end{array}$ & $\begin{array}{l}5.8 \\
\mathbf{5 . 8}\end{array}$ & $\begin{array}{l}2.13 \\
\mathbf{2 . 0 4}\end{array}$ & $\begin{array}{l}2.8 \\
3.5\end{array}$ & $\begin{array}{l}13.75 \\
13.57\end{array}$ & 12.95 & 76.37 & 805.3 & 609.7 \\
\hline $\begin{array}{l}\text { Dec. 6.808/09 (27.03.09) } \\
\text { Parâmetros 12.03.09 } \\
\text { Boletim Focus } 13.03 .09\end{array}$ & 4.52 & 4.16 & 2.31 & 0.59 & $\begin{array}{r}\mathbf{1 0 . 8} \\
10.4\end{array}$ & 6.29 & 47.27 & 756.9 & 578.8 \\
\hline $\begin{array}{l}\text { Dec. 6.867/09 (29.05.09) } \\
\text { Parâmetro 19.05.09 }\end{array}$ & 4.3 & 2.01 & 2.23 & -049 & 10.25 & 5.67 & 53.05 & 745.2 & 593.2 \\
\hline $\begin{array}{l}\text { Dec. 6.923/09 (05.08.09) } \\
\text { Parâmetro 15.07.09 } \\
\text { Boletim Focus }\end{array}$ & 4.42 & 1.35 & 2.08 & -0.34 & $\begin{array}{r}9.98 \\
9.81\end{array}$ & 8.82 & 59.1 & 743.3 & 592.7 \\
\hline $\begin{array}{l}\text { Dec. 6.993/09 (28.10.09) } \\
\text { Parâmetro } 15.07 .09\end{array}$ & 4.42 & 1.35 & 2.08 & 1 & 9.98 & 8.82 & 59.1 & 737 & 601.6 \\
\hline $\begin{array}{l}\text { Dec. 7.027/09 }(07.12 .09) \text { e } \\
\text { Dec. } 7.036 / 09(17.12 .09) \text { - } \\
\text { Parâmetro } 15.07 .09\end{array}$ & 4.27 & -0.44 & 1.99 & 1 & 9.95 & 9.77 & 60.53 & $\begin{array}{l}736.9 \\
741.8\end{array}$ & $\begin{array}{r}602 \\
606.7\end{array}$ \\
\hline $\begin{array}{l}\text { Realizado* } \\
\text { Revisto** }\end{array}$ & 4.31 & -1.44 & 2 & $\begin{array}{r}0.21 \\
-0.23\end{array}$ & 9.92 & 9.35 & 60.56 & 740.6 & 581.5 \\
\hline
\end{tabular}

Fonte: Relatórios de Cumprimento de Metas de Fiscais.

Nota: Decreto 6.752/09 adotou os mesmos parâmetros da LOA.

Ao longo do ano, conforme as estimativas de crescimento do PIB foram sendo revistas para baixo, o Governo foi reduzindo as previsões de arrecadação e de despesa. A Tabela 12 
apresenta a evolução dos parâmetros macroeconômicos previstos, bem como as expectativas de receitas e de despesas programadas. A título de comparação, constam também as previsões de mercado captadas pelo Boletim Focus do Banco Central. Dessa forma, é possível verificar o quanto as previsões do Governo se diferem da previsão do mercado financeiro. Para essa comparação, os Boletins Focus utilizados foram aqueles publicados nas datas mais próximas possível da divulgação dos parâmetros macroeconômicos correspondentes. Essa informação é relevante para uma comparação mais precisa, haja vista a volatilidade observada nestas previsões de um período a outro. Podemos notar que, ao longo de todo o ano de 2009, as expectativas do Governo em relação ao crescimento do PIB foram superestimadas em comparação às expectativas do mercado. Mesmo na avaliação realizada ao final do quinto bimestre, quando o mercado financeiro assumia uma taxa de crescimento negativa para o ano, o Governo ainda estava trabalhando com uma expectativa de crescimento real de $1 \%$. Em relação aos demais parâmetros, as estimativas do Governo se assemelhavam às do Boletim Focus.

Analisando as previsões contidas na LOA, é possível verificar que o Governo se apoiou na tese de que havia um descolamento entre os eventos externos e a economia brasileira. $\mathrm{O}$ diagnóstico era que a crise não afetaria a economia brasileira. De fato, Holland e Mori (2010) citam que havia algumas condições favoráveis na economia brasileira como o elevado volume de reservas internacionais que serviria de seguro contra possíveis ataques especulativos, da elevada taxa de juros que permitiria uma flexibilização por parte da política monetária e da alta valorização precedente do Real frente ao Dólar, havendo espaço para uma possível desvalorização. Porém, como exposto por Holland e Mori (2010), as exportações mundiais se reduziram cerca de $40 \%$ entre agosto e dezembro de 2008 e, em função do acentuado comovimento das exportações das economias desenvolvidas com as economias em desenvolvimento, o comércio internacional seria um canal fundamental na transmissão da crise internacional para as economias emergentes. Entretanto, esse risco, não foi captado durante o planejamento orçamentário. Ao contrário, houve uma demora por parte das Autoridades Fiscais e Monetárias em reagir. O Banco Central, por exemplo, havia iniciado em abril de 2008, e manteve até janeiro de 2009, uma política contracionista, elevando a taxa de juros em um momento em que os principais bancos centrais das economias desenvolvidas estavam reduzindo suas taxas para níveis próximos a zero. As medidas de estímulo começaram a surgir a partir do forte colapso na produção industrial verificado no quarto 
trimestre de 2008, com queda de 7.4\% de acordo com dados do Banco Central do Brasil (2008).

No âmbito fiscal, uma série de medidas de renúncia fiscal foi adotada para conter o aprofundamento da crise no país. ${ }^{57}$ Entre essas medidas, podemos citar: a criação de alíquotas intermediárias de imposto de renda para a pessoa física; reduções das alíquotas do Imposto sobre Produtos Industrializados (IPI) para caminhões e automóveis, materiais de construção civil, móveis e eletrodomésticos da linha branca; redução das alíquotas do Imposto sobre Operações Financeiras (IOF) em operações de empréstimos às pessoas físicas. Em março de 2009, o Governo lançou o programa "Minha Casa, Minha Vida", com recursos para o financiamento da habitação. Os investimentos no âmbito do Programa de Aceleração do Crescimento (PAC) ${ }^{58}$ foram mantidos. Juntamente com os benefícios fiscais ao setor habitacional e com o Minha Casa, Minha Vida, as obras do PAC mantiveram o setor de construção civil aquecido e o emprego no setor.

Com a retração na arrecadação do IPI e do Imposto de Renda, o volume de transferências a estados e municípios foi fortemente afetado. A fim de viabilizar a administração dos municípios, o Governo Federal, por meio da Medida Provisória n. 462, assegurou a esses entes o recebimento, em 2009, de transferências em valores correntes equivalentes aos recebidos em 2008.

Em relação às políticas de renda, o Governo manteve os programas sociais, em especial o Bolsa Família, manteve a política de valorização do salário mínimo, garantindo ganhos reais aos assalariados, inclusive aposentados e pensionistas do INSS e elevou os benefícios do seguro-desemprego. Outras medidas adotadas visaram minimizar a perda de arrecadação como por exemplo: a) o recolhimento à Conta Única do Tesouro, dos depósitos judiciais e extrajudiciais referentes a tributes e contribuições federais, mantidos nas instituições bancárias; e, b) antecipação de dividendos das empresas estatais em que a União detém participação acionária.

\footnotetext{
${ }^{57}$ No âmbito monetário, o Banco Central iniciou um processo de redução da taxa básica de juros, reduzindo a Selic em 5 pontos percentuais entre janeiro e julho de 2009. A taxa de juros atingiu $8.75 \%$ em julho e permaneceu nesse patamar até abril de 2010. Outras medidas monetárias também foram implementadas e podem ser encontradas no Boletim Anual de 2009 do Banco Central do Brasil.

${ }^{58} \mathrm{O}$ PAC foi lançado em 2007.
} 
Além das medidas supracitadas, a medida mais importante adotada pelo Governo para reverter o impacto recessivo do contágio da crise internacional foi a política de sustentação do crédito através dos bancos públicos. Por orientação do Governo Federal, as instituições financeiras públicas (Banco do Brasil, Caixa e BNDES) ampliaram a oferta de crédito e de financiamento. A expansão mais expressiva ocorreu no crédito direcionado, especialmente o crédito habitacional e os financiamentos concedidos pelo BNDES para projetos de infraestrutura e aquisição de máquinas e equipamentos no âmbito do Programa de Sustentação de Investimentos (PSI). ${ }^{59}$ Para viabilizar o crescimento da oferta de crédito, o Governo realizou aportes financeiros no BNDES, por meio da emissão de títulos de dívida. A Dívida Líquida do Setor Público alcançou 42.8\% do PIB em 2009, ante 38.4\% em 2008 e, de acordo com dados do Banco Central, parte desse aumento da dívida ocorreu em função da concessão de crédito do Governo ao BNDES (BANCO CENTRAL DO BRASIL, 2009b).

Ao final do ano de 2009, as estimativas em tempo real do Banco Central indicavam que o crescimento real do PIB havia sido de $0.21 \%$, porém, o dado atualizado indica que houve naquele ano um crescimento negativo de $0.23 \%$. Em função da queda na atividade econômica e das desonerações fiscais que foram realizadas ao longo do ano, a arrecadação foi inferior aos valores previstos, resultando em um desvio de execução negativo, pela primeira vez desde 2002. As despesas também foram menores do que as planejadas no orçamento. No entanto, as despesas primárias cresceram 15\% de 2008 para 2009, de acordo com dados da Secretaria do Tesouro Nacional (BRASIL, 2010). Houve também um aumento em proporção do PIB, enquanto as despesas em 2008 representaram 16.57\% do PIB, em 2009 a proporção aumentou para $18.26 \%$, refletindo o aumento das despesas em um cenário de redução do crescimento econômico. Os gastos com pessoal cresceram 15.9\% entre 2008 e 2009 e as despesas com custeio e capital cresceram $16.9 \%$ no mesmo período. A principal contribuição para o aumento das despesas vieram das obrigações custeadas pelo Fundo de Amparo ao Trabalhador (FAT) que se elevaram 30,5\% no ano (Tabela 13). Os recursos do FAT custeiam o Programa de Seguro-Desemprego, o pagamento do abono salarial e programas de desenvolvimento a cargo do BNDES.

\footnotetext{
${ }^{59}$ O PSI foi lançado em 2009 para concessão de crédito a taxas subsidiadas para compra de máquinas e equipamentos. O programa foi mantido até dezembro de 2011, embora, originalmente, estivesse previsto para acabar em 2010.
} 
Tabela 13 - Despesa Primária Total 2009

\begin{tabular}{cl|cc}
\hline \multirow{2}{*}{ Discriminação } & \multicolumn{2}{|c}{ Variação \% acumulada jan-dez } \\
\cline { 2 - 3 } & $\mathbf{2 0 0 8 / 2 0 0 7}$ & $\mathbf{2 0 0 9 / 2 0 0 8}$ \\
\hline Despesas Primária Total & 9.3 & 15 \\
i. & Benefícios & 7.7 & 12.7 \\
ii. & Pessoal & 12.4 & 15.9 \\
iii. & Custeio e Capital & 8.3 & 16.9 \\
a) & FAT & 12.8 & 30.5 \\
b) & Subsídios & -40.3 & -9.5 \\
c) & LOAS/RMV & 13.0 & 18.1 \\
d) & Outras & 11.4 & 15.7 \\
\hline
\end{tabular}

Fonte: Secretaria do Tesouro Nacional (BRASIL, 2010).

Em setembro de 2009, por meio da Lei $12.053 / 2009$, a LDO foi modificada e a meta de superávit primário para o setor público consolidado foi reduzida de $3.8 \%$ para $2.50 \%$ do PIB. A Petrobrás foi excluída do cálculo do superávit primário, isto é, a empresa poderia realizar seus investimentos sem as restrições impostas pela necessidade de contribuir com o resultado fiscal. Adicionalmente, a LDO passou a considerar os gastos efetivamente realizados no âmbito do PAC, acrescidos dos restos a pagar executados no exercício até o montante de $\mathrm{R} \$$ 28.5 bilhões, passíveis de dedução da meta de resultado primário. ${ }^{60}$ A LDO 2009 também permitiu que pagamentos de despesas empenhadas em orçamentos anteriores, até o montante dos restos à pagar inscritos no encerramento de 2008, pudessem ser deduzidos da meta de superávit primário. Soma-se às mudanças na LDO, a antecipação de dividendos a receber das estatais e a venda desses dividendos ao BNDES para elevar a receita disponível. Na prática, todas essas medidas permitiram que a meta do superávit fiscal fosse artificialmente atingida. O superávit primário em 2009 foi de $1.25 \%$ do PIB para o Governo Central e $2.06 \%$ do PIB para o setor público consolidado. Considerando-se as deduções no âmbito do PAC no total de $0,57 \%$ do PIB, a meta prevista na LDO foi atingida.

A Lei Orçamentária para 2010, elaborada sob os efeitos da crise financeira internacional em um contexto de queda brusca na atividade econômica doméstica, manteve o tom de otimismo presente nos orçamentos anteriores. Dessa vez, as expectativas otimistas em relação ao PIB foram realizadas. A taxa de crescimento real ficou 2.57 p.p. acima da previsão inicial da LOA

\footnotetext{
${ }^{60}$ Até 2009, eram passíveis de dedução da meta de resultado primário, na medida de sua execução, somente os projetos do PPI - Projeto Piloto de Investimento.
} 
(7.57\% contra uma previsão de 5\%). Segundo dados do Banco Central, o desvio positivo ocorrido na taxa de crescimento foi puxado pelo consumo das famílias, cujo aumento de 7\% no ano foi incentivado pelos ganhos de renda real e pela expansão do crédito, e pela formação bruta de capital fixo que apresentou crescimento de $21.8 \%$ no ano, consistente com os recursos destinados às obras de financiamento imobiliário e às obras de infraestrutura no âmbito do PAC (BANCO CENTRAL DO BRASIL, 2010).

O crescimento acima das expectativas iniciais gerou um recorde de arrecadação e, consequentemente, um recorde no desvio de execução positivo das receitas de $R \$ 47.2$ bilhões. Com o aumento da arrecadação, os gastos totais também atingiram valor recorde, alcançando 19.14\% do PIB, o maior valor até então, desde 1997, resultando em um desvio de execução da despesa positivo em R 21 bilhões. É válido observar que 2010 era ano eleitoral e que a elevação dos desvios de execução em anos eleitorais é um resultado coerente com a intenção do governo em exercício em eleger seu sucessor.

Em relação ao superávit primário, a meta fixada na LDO 2010 era de 3.3\% do PIB para o setor público consolidado, sendo $2.15 \%$ relativos ao Governo Central, $0,20 \%$ relativos às Estatais e o restante para os estados, Distrito Federal e municípios. A LDO também determinou que as despesas no âmbito do PAC pudessem ser deduzidas do superávit primário em até R 22.5 bilhões. Também poderiam ser deduzidas as despesas com "restos a pagar" relativos aos investimentos do PAC e PPI e o excesso da meta de superávit primário apurado no exercício de 2009. Posteriormente, o limite de abatimento das despesas do PAC foi elevado para $\mathrm{R} \$ 29.8$ bilhões (Lei 12.182/2009). No final de 2010, ocorreu outra mudança na meta de superávit primário. Por meio da Lei 12.377 de dezembro de 2010, foi concedido tratamento especial ao Grupo Eletrobrás, excluindo-o do cálculo do resultado primário, de forma semelhante ao que havia sido feito com o Grupo Petrobrás a partir da LDO 2009. Dessa maneira, a meta de resultado primário para o setor público consolidado caiu para $3.1 \%$ do PIB e a meta para as estatais foi estabelecida em $0 \%$.

Além das deduções previstas na LDO, outra operação atípica realizada ao longo de 2010 e que ajudou no cumprimento da meta fiscal foi o recebimento líquido de receitas derivadas do pagamento de cessão onerosa pela Petrobrás. A União cedeu àquela estatal o direito de explorar o petróleo da camada do pré-sal. Por esse direito, chamado de cessão onerosa, a Petrobrás pagou ao Tesouro $\mathrm{R} \$ 74.8$ bilhões. Desse total, $\mathrm{R} \$ 42.9$ bilhões foram utilizados 
pelo Tesouro para capitalizar a estatal e o saldo de $\mathrm{R} \$ \mathrm{R} \$ 31.9$ bilhões foi contabilizado como superávit primário.

Apesar do crescimento da arrecadação acima do previsto, a meta de superávit primário em 2010 só foi atingida em função das deduções relativas às despesas do PAC e em função das receitas líquidas derivadas do pagamento de cessão onerosa pela Petrobrás.

Se pelo lado fiscal, o Governo atuava no sentido de estimular a economia, expandindo os gastos públicos, pelo lado monetário, o Banco Central atuou no sentido de conter pressões inflacionárias. A partir de abril de 2010, o Banco Central iniciou uma política de elevação da taxa de juros básica que só foi interrompida em agosto de 2011. Nesse período, a taxa Selic elevou-se em 3.75 p.p., passando de $8.75 \%$ ao ano para $12.50 \%$. Adicionalmente, no final de 2010 o Banco Central adotou um conjunto de medidas macroprudenciais para conter a expansão do crédito ao consumidor, avaliada como excessiva naquele momento. Além de conter o endividamento das famílias, as medidas visavam também reduzir à exposição ao risco das instituições bancárias, mediante a imposição de restrições às operações dessas instituições. Entre as medidas adotadas estavam o aumento da taxa de juros e redução dos prazos para financiamentos, elevação de IOF sobre operações de crédito à pessoa física, elevação de percentual mínimo para pagamento da fatura de cartão de crédito, elevação dos requerimentos compulsórios e aumento do requerimento de capital para operações de crédito a pessoa física (PRATES e CUNHA, 2012).

\section{4}

O Período 2011 a 2015 - O Governo Dilma e a Elevação dos Desvios de Execução

O Governo Dilma pode ser dividido em 3 subperíodos: a) O primeiro período, referente ao ano de 2011, em que foram adotadas medidas restritivas de caráter anticíclico; b) O período de 2012 a 2014, no qual foram adotadas medidas de estímulo a economia no âmbito da chamada "Nova Matriz Macroeconômica"; e, c) O ano de 2015, após a reeleição da Presidente, em que o Governo assumiu os problemas econômicos existentes, sobretudo no âmbito fiscal, e iniciou a adoção de medidas de ajuste para resolvê-los. 
O Orçamento para 2011 foi elaborado seguindo a linha de otimismo observada em todos os orçamentos anteriores. Nesse sentido, esperava-se crescimento real do PIB em 5\%, com inflação convergindo para o centro da meta, declínio nos juros e na DLSP/PIB, queda no déficit nominal, ampliação dos investimentos do Governo Federal, ampliação das políticas de inclusão social e manutenção do esforço fiscal em 3.3\% do PIB. A expectativa de crescimento sugerida na PLOA foi mantida pelo Congresso. No primeiro semestre do ano foram adotadas medidas restritivas para desaquecer a economia, dando sequência às medidas macroprudenciais e a elevação dos juros realizada pelo Banco Central desde 2010. A partir do segundo semestre de 2011, a situação fiscal e de financiamento da dívida pública se agravou nos países da Zona do Euro, com reflexos sobre o crescimento econômico mundial, a percepção de risco e volatilidade nos mercados financeiros. Com o recuo na previsão de crescimento, o Governo brasileiro interrompeu as medidas restritivas que estavam em prática desde 2010 e adotou um conjunto de medidas de incentivo fiscal a setores específicos com o objetivo de estimular o investimento. O crescimento do PIB em 2011 ficou abaixo das expectativas contidas na LOA. O desvio de execução da receita em relação à LOA foi de $\mathrm{R} \$$ 0.6 bilhões, o menor desvio positivo observado entre 2002 e 2015 (em 2006, o desvio foi negativo em $\mathrm{R}$ \$ 0.6). Em relação à despesa, o desvio foi maior e igual a $\mathrm{R}$ \$ 39.1 bilhões negativos, isto é, a despesa ficou abaixo dos valores previstos na LOA.

Os problemas em relação aos desvios de execução orçamentários agravaram-se a partir de 2012, quando os desvios entre receita realizada e prevista e os desvios em relação às previsões dos parâmetros macroeconômicos tornaram-se crescentes. Além do agravamento da crise externa, o ano de 2012 foi marcado pelo fim do ciclo de commodities não antecipado no orçamento e pelo fortalecimento do dólar. O dólar fraco e a elevação nos preços das commodities exportadas pelo Brasil haviam sido protagonistas no ciclo de crescimento observado durante o Governo Lula. Com a queda no preço das commodities, houve um efeito multiplicador negativo que ajudou a reduzir o crescimento econômico e, consequentemente, reduzir a arrecadação.

De 2012 a 2014, com o intuito de sustentar o crescimento em nível elevado, diante do agravamento da crise fiscal nos países da Zona do Euro, o Governo Dilma adotou uma série de medidas que se mostraram equivocadas e culminou em piora da situação fiscal, deterioração das expectativas, queda do investimento e redução do crescimento econômico. Pelo lado orçamentário, houve queda da arrecadação e elevação dos gastos públicos, 
resultando em desvios de execução crescentes tanto em relação à receita quanto em relação à despesa.

As medidas de estímulo adotadas ficaram conhecidas como "Nova Matriz Macroeconômica" em referência ao fato de que tais medidas eram contrárias à sustentação do tripé macroeconômico composto por metas de inflação, superávits primários e câmbio flutuante que vigorara desde o segundo mandato do Presidente Fernando Henrique. Na prática, a Nova Matriz Macroeconômica entrou em vigor, ainda de forma menos evidente, após 2008, durante o Governo Lula e em resposta aos efeitos da crise financeira do subprime. O Governo Dilma ampliou as medidas de estímulo e institucionalizou a nova matriz.

De modo geral, a nova matriz pode ser caracterizada por política fiscal expansionista, expansão do crédito a baixo custo através de bancos públicos, câmbio desvalorizado, redução das taxas de juros, estímulo à industria nacional através de elevação das taxas de importação, exigência de requisitos mínimos de insumos nacionais, ampliação do financiamento a setores estratégicos e manutenção do consumo para estimular o crescimento.

Em uma tentativa de reduzir os custos de produção, além de conter a elevação da inflação, o Governo interviu no setor elétrico por meio da renovação antecipada de contratos de concessão de geração, transmissão e distribuição de energia elétrica que venceriam de 2015 a 2017, além de reduzir encargos do setor. De acordo com a Lei 12.783 de janeiro de 2003, as concessões de geração de energia poderiam ser renovadas uma única vez pelo prazo de 30 anos. A aceitação da renovação dependia da aceitação da remuneração por tarifa calculada pela Agência Nacional de Energia Elétrica (ANEEL). Na prática, o Governo reduziu o preço pago pela geração, reduzindo o tarifa final paga pelo consumidor.

Embora a redução do preço da energia seja um fator importante para conter o custo Brasil (CONJUNTURA ECONÔMICA, 2013), a medida adotada pelo Governo foi controversa, principalmente porque gerou desequilíbrios no setor elétrico que precisaram ser corrigidos em 2015, quando os preços da energia voltaram a subir em um contexto em que a inflação já estava elevada. A medida provocou desequilíbrios entre as despesas e as receitas das empresas geradoras. Adicionalmente, em 2013 ocorreu aumento do consumo de energia combinado com redução no volume de chuvas e atrasos de investimentos no setor. Com redução na oferta de energia e aumento no consumo, foi preciso recorrer às termelétricas que 
possuem um custo mais elevado de produção. Em 2014, com o agravamento da estiagem, os gastos com as termelétricas aumentaram. No entanto, o custo mais elevado não foi repassado ao consumidor, o que seria considerada uma atitude impopular para um ano eleitoral. Foi preciso repassar subsídios às empresas do setor para cobrir os prejuízos acumulados pelas geradoras, criando mais uma fonte de elevação dos gastos públicos. Em 2015, passadas as eleições, o governo permitiu que os custos maiores com a produção de energia fossem repassados aos consumidores e o aumento acumulado da energia elétrica superou os $50 \%$ no ano. ${ }^{61}$

Além do setor elétrico, o governo também utilizou a Petrobrás para tentar manter a inflação dentro da meta. A estatal passou a vender gasolina para as distribuidoras por um preço congelado, sem repassar as variações dos preços de importação, em um contexto em que o dólar estava se valorizando e o preço do barril do petróleo estava em ascensão. Adicionalmente, o Governo impôs um custo maior à produção e aos investimentos da Petrobrás, ao exigir um percentual mínimo de componentes domésticos na construção de plataformas de perfuração e na constituição das equipes que trabalhassem nessas plataformas. O congelamento do preço da gasolina e a manutenção de investimentos relacionados ao présal, considerados estratégicos pelo Governo, elevou o endividamento da empresa, ao mesmo tempo em que veio à tona o esquema de corrupção que operava na estatal com envolvimento de agentes políticos, incluindo pessoas ligadas ao Governo, derrubando o valor da empresa no mercado acionário.

Disposto a reduzir a taxa de juros, o Governo Dilma utilizou o Banco do Brasil e a Caixa para expandir o crédito com taxas de juros mais baixas que as praticadas pelo mercado. Em um primeiro momento, os bancos públicos expandiram suas receitas e elevaram suas participações no mercado de crédito. Esse movimento forçou os bancos privados a reduzirem seus spreads, levando a uma queda na taxa de juros efetiva paga por consumidores e empresa, tanto no crédito com recursos livres, como o crédito com recursos direcionados.

A redução da taxa de juros efetiva da economia foi facilitada pela redução da taxa básica pelo Banco Central. Entre agosto de 2011 e outubro de 2012, a Selic foi reduzida em 5.25 pontos percentuais saindo de $12.5 \%$ para $7.25 \%$ ao ano e permanecendo nesse nível até março de

${ }^{61}$ O Relatório de Inflação de dezembro de 2015 aponta uma elevação de 50,48\% na energia elétrica no acumulado anual até o mês de novembro. 
2013, quando o afrouxamento monetário foi interrompido. A atuação do Banco Central gerou dúvidas a respeito de qual meta de inflação estava sendo perseguida, haja vista que ao longo de 2012 ocorreram pressões inflacionárias que levaram a inflação medida pelo IPCA a alcançar 5.84\% no acumulado em 12 meses, valor acima do centro da meta.

O BNDES continuou desempenhando papel fundamental na expansão do crédito, mediante aportes financeiros do Tesouro Nacional. O Programa de Sustentação do Investimento, vigente desde 2009, foi prorrogado e a Taxa de Juros de Longo Prazo, destinada ao financiamento de projetos de investimento, foi reduzida. Em agosto de 2011 foi lançado Plano Brasil Maior (PBM) que, segundo descrição do BNDES, tinha por objetivo articular os esforços de política industrial do Governo Federal para o período de 2011 a 2014, com foco no estímulo à inovação e à competitividade da indústria (BNDES, 2011). Uma série de medidas de desoneração fiscal fez parte do PBM. Além de medidas para viabilizar o investimento privado, o Governo adotou medidas com o objetivo de viabilizar o investimento público. Dessa forma, no final de 2011, o governo federal autorizou a ampliação dos limites de endividamento dos estados junto ao BNDES e instituições financeiras internacionais. Adicionalmente, em junho de 2012, o Governo Federal divulgou o Programa de Compras Governamentais, sob o qual foram previstos $\mathrm{R} \$ 8.43$ bilhões de compras, beneficiando diferentes setores (CAGNIN et alli, 2013).

Mesmo com os sinais de desaceleração, o Governo continuou elaborando orçamentos fundamentados em expectativas otimistas de crescimento do PIB. No entanto, apesar das medidas expansionistas adotadas, as expectativas em relação ao crescimento econômico foram frustradas. Consequentemente, a arrecadação também ficou abaixo dos valores previstos em todos os anos, com exceção de 2011 (Tabela14). Nesse cenário de arrecadação em queda e gastos crescentes, o Governo lançou mão de manobras contábeis para manter as contas públicas artificialmente equilibradas. Entre essas manobras estão o atraso de repasses às instituições financeiras que custearam despesas do governo, tais como os benefícios sociais e previdenciários, o abono salarial e o seguro-desemprgo, subsídios, despesas do programa Minha Casa, Minha Vida; adiantamentos concedidos pelo BNDES à União; abertura de créditos suplementares incompatíveis com a obtenção da meta de resultado primário, entre outros medidas que ficaram popularmente conhecidas como "pedaladas fiscais" e que estão sendo julgadas quanto às suas legalidades. 
Tabela 14 - Previsões contidas na LOA versus valores realizados

\begin{tabular}{llrrr}
\hline Ano & Etapa & PIB & Receita & Despesa \\
\hline 2011 & Previsto LOA & 5.0 & 990.5 & 773.6 \\
& Realizado & 3.92 & 991.0 & 734.5 \\
2012 & Previsto LOA & 4.5 & $1,127.3$ & 864.0 \\
& Realizado & 1.76 & $1,060.3$ & 813.0 \\
2013 & Previsto LOA & 4.5 & $1,253.4$ & 964.6 \\
& Realizado & 2.74 & $1,179.0$ & 920.1 \\
2014 & Previsto LOA & 3.8 & $1,331.6$ & $1,052.9$ \\
& Realizado & 0.15 & $1,221.5$ & $1,040,2$ \\
2015 & Previsto LOA & 0.77 & $1,447.8$ & $1,168.1$ \\
& Realizado & -3.8 & $1,228.7$ & $1,158.7$ \\
\hline
\end{tabular}

Fonte: Relatórios de Avaliação Cumprimento de Metas Fiscais.

Em 2015, os efeitos negativos das medidas expansionistas, adotadas no âmbito da Nova Matriz Macroeconômica, tornaram-se mais fortes. Passada a eleição presidencial em outubro de 2014, a taxa de juros Selic começou a ser elevada e, em 2015, atingiu 14.15\%, retornando ao patamar observado em 2006. A DLSP atingiu 36.2\% do PIB em dezembro de 2015, contra 30.6 em dezembro de 2013 (menor nível do Governo Dilma). O endividamento bruto cresceu ainda mais, passando de 51.8\% do PIB em dezembro de 2010, no início da Gestão Dilma, para $66.5 \%$ em dezembro de 2015. Os preços administrados, da gasolina e da energia, que haviam sido congelados, foram liberados e, juntamente, com a desvalorização cambial, colaboraram para o descumprimento da meta de inflação, o IPCA fechou o ano de 2015 com variação de $10.67 \%$, contra uma meta de $4.5 \%$, com dois pontos percentuais de intervalo de tolerância. Adicionalmente, o país perdeu o grau de investimento que havia recebido em 2008. Diante da deterioração das contas públicas e da perda de credibilidade na capacidade do governo de resolver a situação, a taxa de câmbio disparou atingindo $\mathrm{R} \$ 3.87$ em dezembro de 2015, gerando pressões adicionais sobre o nível de preços.

Observa-se que a previsão fiscal deteriorou-se severamente durante o Governo Dilma. Ao longo dos 5 anos de governo, as medidas anticíclicas adotadas, não antecipadas no orçamento, geraram um desequilíbrio nas contas. Além de a arrecadação ter ficado aquém das expectativas contidas no orçamento, as despesas aumentaram em um percentual superior ao aumento nas receitas (exceto no ano de 2011), conforme dados da Tabela 15. 
Tabela 15 - Variação Receita e Despesa

\begin{tabular}{l|ccccc}
\hline \multirow{2}{*}{\multicolumn{1}{c|}{ Discriminação }} & \multicolumn{5}{c}{ \% Variação Real } \\
\cline { 2 - 6 } & $\mathbf{2 0 1 1 / 2 0 1 0}$ & $\mathbf{2 0 1 2 / 2 0 1 1}$ & $\mathbf{2 0 1 3 / 2 0 1 2}$ & $\mathbf{2 0 1 4 / 2 0 1 3}$ & $\mathbf{2 0 1 5 / 2 0 1 4}$ \\
\hline Receita Primária & 7.7 & 7.2 & 11.2 & 3.6 & -6.3 \\
Transferências & 22.6 & 5.2 & 4.7 & 10.6 & -5.8 \\
Despesa Primária & 3.4 & 11.1 & 13.6 & 12.8 & 2.1 \\
\hline
\end{tabular}

Fonte: Relatórios Resultado do Tesouro Nacional.

Até 2013 o Governo anunciou a obtenção de superávits primários. Nos anos de 2014 e 2015, o resultado primário do Governo Central foi deficitário, respectivamente, em $0.34 \%$ e $1.94 \%$ do PIB. A Tabela 16 apresenta a meta de resultado primário estabelecida para o Governo Central na LDO e os resultados atingidos. As metas indicadas são aquelas definidas na LDO original, sem considerar as mudanças que são executadas ao longo do ano. Em 2013, 2014 e em 2015, por exemplo, foram feitas alterações na LDO entre os meses de novembro e dezembro dos respectivos anos, quando o não cumprimento da meta já era evidente. Ou seja, na prática, as mudanças ocorreram para legalizar o resultado inferior à meta inicial.

Tabela 16 - Resultado Primário Governo Central - Governo Dilma

\begin{tabular}{lccccc}
\hline & $\mathbf{2 0 1 1}$ & $\mathbf{2 0 1 2}$ & $\mathbf{2 0 1 3}$ & $\mathbf{2 0 1 4}$ & $\mathbf{2 0 1 5}$ \\
\hline Meta LDO & 2.15 & 2.15 & 2.15 & 2.15 & 2.0 \\
Resultado Primário & 2.26 & 2.01 & 1.59 & -0.34 & -1.94 \\
\hline
\end{tabular}

Fonte: Relatórios Resultado do Tesouro Nacional.

Além de adotar a prática corriqueira de propor mudanças na meta de superávit, o Governo também teve a sua disposição à possibilidade de deduzir do cálculo do resultado primário as despesas realizadas no âmbito do PAC. Diante da elevação observada nas despesas e da arrecadação abaixo do previsto, os superávits obtidos só foram possíveis mediante o subterfúgio das deduções das despesas do PAC. Sem entrar no mérito dos benefícios de longo prazo que são obtidos com o aumento dos investimentos, a dedução destas despesas caracteriza-se uma distorção da proposta do superávit que é gerar uma poupança para pagar os juros da dívida em relação ao PIB, evitando seu crescimento. Adicionalmente, invalidou a meta de superávit fiscal contida na LDO, haja vista que a meta passou a ser utilizada apenas como uma referência e não como um objetivo a ser alcançado. 
Outra maneira utilizada para garantir o cumprimento da meta fiscal, foi a adoção da prática, cada vez mais frequente, de postergar o pagamento de despesas, contabilizando-as como Restos a Pagar. A Tabela 17 apresenta a evolução dessa rubrica a partir de 2002. Ao longo dos anos, o Governo inflou essa conta, adiando pagamentos, para garantir que as despesas efetivamente liquidadas no exercício fossem compatíveis com a obtenção da meta de resultado primário.

Tabela 17 - Restos a Pagar Inscritos no Ano de Referência

\begin{tabular}{cccc}
\hline Ano & Processados & Não Processados & Total \\
\hline 2002 & $6,508,329.00$ & $14,517,258.00$ & $21,025,587.00$ \\
2003 & $9,740,239.00$ & $23,758,944.00$ & $33,499,183.00$ \\
2004 & $4,889,012.00$ & $17,384,523.00$ & $22,273,535.00$ \\
2005 & $5,595,024.00$ & $33,977,924.00$ & $39,572,948.00$ \\
2006 & $6,938,064.00$ & $38,749,803.00$ & $45,687,867.00$ \\
2007 & $7,051,461.68$ & $55,136,800.90$ & $62,188,262.58$ \\
2008 & $24,034,903.55$ & $67,937,227.92$ & $91,972,131.47$ \\
2009 & $21,849,700.16$ & $92,126,197.19$ & $113,975,897.35$ \\
2010 & $24,642,340.18$ & $103,282,259.86$ & $127,924,600.04$ \\
2011 & $24,092,365.06$ & $116,937,762.55$ & $141,030,127.61$ \\
2012 & $26,275,774.24$ & $150,401,343.05$ & $176,677,117.29$ \\
2013 & $33,607,897.70$ & $185,132,731.62$ & $218,740,629.32$ \\
2014 & $38,449,376.71$ & $188,362,271.85$ & $226,811,648.56$ \\
2015 & $45,260,000.00$ & $141,049,000.00$ & $186,309,000.00$ \\
\hline
\end{tabular}

Fonte: Secretaria do Tesouro Nacional - Séries Estatisticas

A crescente inscrição de despesas em restos a pagar cria um problema de credibilidade em relação ao planejamento e execução orçamentária. Durante o exercício, executa-se um orçamento diferente daquele que foi planejado para o exercício em referência. Executam-se despesas de orçamentos anteriores com a receita arrecadada no exercício corrente, criando uma espécie de orçamento paralelo. Essa prática contribui para gerar baixa previsibilidade em relação à execução do orçamento corrente, além de lançar dúvidas a respeito da própria validade do orçamento.

Todos esses mecanismos, que a princípio foram criados para dar flexibilidade ao gestor da política fiscal, diante das imprevisibilidades inerentes à economia, acabaram sendo adotados como instrumentos de acesso irrestrito, contribuindo para transformar o orçamento público brasileiro em uma mera peça legal, sem validade prática para guiar as expectativas em relação à trajetória da política fiscal. 


\section{DETERMINANTES POLÍTICOS E ECONÔMICOS DOS DESVIOS DE EXECUÇÃO DA POLÍTICA FISCAL NO BRASIL}

\subsection{Introdução}

O objetivo deste capítulo é identificar os determinantes políticos e econômicos dos desvios de execução orçamentária no Brasil no período de 2002 a 2015. A literatura sobre erros de previsão, analisada no capítulo 2 desta tese, associa os erros de previsão orçamentários aos desvios entre planos e execução da política fiscal. De acordo com essa visão, a falha em realizar previsões orçamentárias mais precisas e se ater ao cumprimento do orçamento resulta em descumprimento dos objetivos fiscais, com reflexos negativos sobre as contas públicas do país. Dessa forma, é necessário investigar quais fatores contribuem para explicar os desvios do orçamento planejado. Nesta pesquisa, voltaremos nosso foco para um dos componentes do orçamento, a receita primária total, e iremos avaliar, dentre as variáveis identificadas pela literatura, quais as mais prováveis para influenciar a previsão das receitas e os desvios entre previsão e arrecadação efetiva.

A análise será realizada utilizando dados em tempo real dos orçamentos anuais e dos demais relatórios oficiais disponibilizados ao longo das diferentes fases do ciclo orçamentário e listados anteriormente nesta tese. Este capítulo complementará os dois capítulos anteriores na medida em que determinar empiricamente os fatores condicionantes que guiaram as ações de gerenciamento da política fiscal brasileira durante as fases de planejamento e execução do orçamento. Para alcançar o objetivo proposto, o capítulo estará estruturado da seguinte forma: Na seção 2 apresentaremos o modelo de regressão geral. Na terceira seção, identificaremos as variáveis dependentes e as variáveis explicativas utilizadas nas regressões. $\mathrm{Na}$ quarta seção, apresentaremos os aspectos metodológicos da análise econonométrica. $\mathrm{Na}$ quinta seção, apresentaremos os resultados da análise econométrica dos determinantes dos desvios de execução e os resultados da análise dos determinantes da fase de planejamento. Por fim, apresentaremos as considerações finais do capítulo. 
Serão estimadas duas equações, uma para a fase de execução, pela qual iremos identificar os determinantes do desvio entre receita realizada e receita prevista e outra para a fase de planejamento, pela qual tentaremos identificar os determinantes da previsão de receita. As equações estimadas baseiam-se nas equações propostas por Beetsma et alli (2013), adaptadas às variáveis disponíveis para a economia brasileira. $\mathrm{O}$ modelo sugerido por Beetsma et alli (2013) será utilizado por contemplar objetivos semelhantes aos desta tese, quais sejam, a análise dos determinantes dos desvios de execução e, além disso, trata-se de um modelo aplicado ao caso de um única economia, a Holanda, ao contrário das principais pesquisas indicadas na literatura que lidam com a análise simultânea de vários países. ${ }^{62}$

O modelo de regressão para a fase de execução orçamentária é o seguinte:

$R E C_{D E S V I O}=\gamma_{0}+\gamma_{1} M A C R O+\gamma_{2} P O L+\gamma_{3} I N S T+\vartheta$

$R E C_{D E S V I O}$ representa o desvio de execução da receita primária, calculado como a diferença entre a receita prevista para o período t e a estimativa da receita que se torna disponível no final do período t. Em outras palavras, é o valor da receita efetivamente arrecadada em tempo real da variável. O grupo MACRO inclui as previsões das variáveis macroeconômicas e as variáveis econômicas e orçamentárias em tempo-real relevantes para o estágio de execução fiscal, o grupo POL inclui os possíveis determinantes políticos dos desvios dos planos fiscais e o grupo INST refere-se aos eventos atípicos e as medidas de política econômica adotadas durante o período sob análise e que possam ter influenciado os desvios de execução. O termo $\vartheta$ é o resíduo.

De forma análoga, a equação que será estimada para a fase de planejamento orçamentário segue a seguinte especificação:

$R E C \_P R E V=\beta_{0}+\beta_{1} M A C R O+\beta_{2} P O L+\beta_{3} I N S T+\varepsilon$

\footnotetext{
${ }^{6262}$ Apesar de estarmos citando especificamente as equações propostas por Beetsma et alli (2013), trata-se de uma equação comum às pesquisas que investigam os determinantes dos erros de previsão. Versões semelhantes podem ser encontradas em Afonso e Carvalho (2014), Afonso e Silva (2012) e Pina e Venes (2011) entre outros.
} 
Em que REC_PREV é a variável orçamentária que se pretende explicar e refere-se ao valor estimado no período t - 1 para a Receita Primária Total em t. De forma similar ao apresentado na equação (1), os termos MACRO, POL e INST se referem, respectivamente, às variáveis macroeconômicas, políticas e aos eventos e medidas econômicas utilizadas para explicar o planejamento orçamentário. $\varepsilon$ é um termo de resíduo.

Esta subseção identifica as variáveis dependentes e as variáveis explicativas utilizadas na análise de regressão. A escolha dessas variáveis foi guiada pela literatura apresentada anteriormente, condicionadas pelas particularidades da economia e pela oferta de dados disponíveis. A base de dados contendo as referidas variáveis foi construída conforme explicação apresentada no Capítulo 4, a partir dos dados e informações contidos nos documentos orçamentários oficiais listados no Apêndice $2 .{ }^{63}$ Os dados são bimestrais e se referem ao período do primeiro bimestre de 2002 ao sexto bimestre de 2015. As estatísticas descritivas das variáveis dependentes e das variáveis explicativas testadas são apresentadas no Apêndice 2 e, os gráficos com o comportamento dessas variáveis estão nos Apêndices 3 e 4.

\subsubsection{Variáveis dependentes}

\section{Desvio de Execução da Receita Prevista (REC_DESVIO):}

Como vimos no capítulo II, usaremos o termo "desvio de execução" para nos referirmos ao desvio do valor observado em relação ao valor previsto, em que um desvio de execução

\footnotetext{
63 Uma mesma variável pode ter mais de uma fonte de referência. É o caso, por exemplo, das informações sobre a taxa de crescimento real do PIB, disponível na Mensagem Presidencial que encaminha a LOA, nos Relatórios e Pareceres do Congresso, nos Relatórios Bimestrais de Avaliação da Política Fiscal, etc. As previsões contidas em cada um desses documentos referem-se às expectativas relativas a diferentes períodos no tempo. Como utilizamos uma base de dados bimestral, diferentes documentos foram sendo utilizados para a construção da base de dados, conforme as datas de publicação e disponibilidade dos mesmos.
} 
negativo reflete uma superestimação da variável observada, ao passo que um desvio positivo é interpretado como uma previsão subestimada da variável observada. É medida em R \$ bilhões.

\section{Previsão de Arrecadação da Receita Total do Governo Central (REC_PREV) :}

Corresponde à expectativa de arrecadação da Receita do Tesouro Nacional, mais a Receita da Previdência Social e Receita do Banco Central, medida em R\$ bilhões.

\subsubsection{Variáveis explicativas}

As variáveis explicativas que serão testadas quanto a sua capacidade para explicar a Receita Total Prevista do Governo Central e os Desvios de Execução da Receita Primária Total foram divididas em variáveis macroeconômicas, variáveis políticas e variáveis de política econômica.

\section{Variáveis Econômicas}

1) Crescimento Econômico Esperado (PIB_PREV): Consiste na previsão divulgada no bimestre de referência da taxa anual de crescimento do PIB real. Espera-se uma relação positiva entre essa variável e a receita esperada, ou seja, quanto maior o crescimento esperado, maior a expectativa de arrecadação.

2) Desvio no Crescimento Econômico Esperado (PIB_DESVIO): Representa a surpresa no crescimento do PIB, isto é, a diferença entre a taxa de crescimento efetiva e a taxa de crescimento real prevista. Quanto maior esse desvio, maior o desvio de execução da receita. Em outras palavras, quanto mais o crescimento do PIB superar o crescimento esperado, maior será a arrecadação efetiva em relação a arrecadação prevista.

3) Despesa Primária Total Prevista (DESP_PREV): Refere-se aos valores previstos da despesa primária total do Governo Federal, incluindo os benefícios da Previdência Social. Também é medida em $\mathrm{R} \$$ bilhões. 
4) Desvio da Despesa Primária Total (DESP_DESVIO): Refere-se à diferença entre as despesas efetivamente realizadas e as despesas primárias planejadas.

\section{5) Dívida Líquida do Setor Público Prevista (DLSP_PREV)}

Valor previsto no bimestre de referência para o percentual anual da relação DLSP/PIB. Quanto maior a dívida pública, maior a necessidade de arrecadação e de superávit primário para evitar o crescimento da relação dívida/PIB. Portanto, espera-se que ocorra uma influência positiva da dívida sob o resultado fiscal, reduzindo o desvio de execução. Os documentos orçamentários utilizados para a construção da base de dados não apresentam informações bimestrais sobre as previsões da DLSP. Constam apenas previsões anuais nos documentos da LDO e da LOA. Dessa maneira, para construção da série bimestral da DLSP/PIB prevista, utilizamos as previsões de mercado divulgadas pelo Banco Central do Brasil no Boletim Focus.

6) Desvio de Execução da Dívida Líquida do Setor Público (DLSP_DESVIO): Tratase da diferença entre a DLSP/PIB efetiva e a DLSP/PIB prevista.

7) Desvio da Taxa de Inflação Média Esperada (IPCA_DESVIO) e Desvio da Taxa de Inflação Média Esperada (IGPDI_DESVIO): Representam, respectivamente, as diferenças entre as taxas de inflação médias anuais efetivas e as expectativas de taxas médias anuais de inflação medidas pelo IPCA e pelo IGP-DI.

8) Índice de Commodities Internacional (CRB): É um índice que mede o movimento geral dos preços das commotities, A elevação dos preços das commodities eleva a arrecadação brasileira e reduz o desvio de execução, na medida em a economia recebe mais por suas exportações e pelos impostos e royalties associados ao setor do petróleo. Por outro lado, a expectativa de elevação no preço das commodities pode elevar o desvio de execução, na medida em que o Governo elevar a previsão de arrecadação.

9) CAMBIO_PREV: Taxa de câmbio R $\$ / U S \$$ média anual prevista.

10) SELIC_PREV: Taxa de juros Selic média anua prevista. 
11) Desvio da Taxa de Câmbio Média Anual Prevista (CAMBIO_DESVIO) : diferença entre a taxa de câmbio média anual efetiva e a taxa média anual prevista.

12) Desvio da Taxa de Juros Selic (SELIC_DESVIO): Desvio entre a taxa de juros realizada e a taxa de juros prevista nos documentos orçamentários.

\section{Variáveis Políticas}

\section{1) POLITIC}

O objetivo é aferir a influência das variáveis políticas sobre as previsões e desvios orçamentários. Porém, a escolha dessas variáveis é limitada pelo fato de que os dados são bimestrais e que as mudanças nas variáveis políticas ocorridas ao longo do período sob análise não geraram variabilidade suficiente para serem testadas. Por exemplo, só houve uma mudança do partido que assumiu o governo, ocorrida em 2003. O mesmo argumento aplica-se a outras variáveis como ideologia do governo, fragmentação política, tipo de governo entre outras. Para lidar com essas limitações, construímos a variável POLITIC, cujos dados puderam ser apresentados em termos bimestrais, mas que não é livre de problemas relativos à sua constituição. Trata-se de uma proxy para o apoio político que o Governo obtem do Congresso. É o número de deputados que votaram de acordo com a orientação do líder do governo em $90 \%$ das votações ou mais. Os dados foram retirados do Basômetro, uma base de dados do Jornal Estadão. O uso desta base de dados deve ser visto com ressalvas, haja vista não se tratar de informações oficiais. O mais indicado seria utilizar as informações a respeito dos partidos e da proporção de parlamentares que fazem parte da base de apoio do Governo no Congresso. No entanto, como ressaltamos, com dados sobre composição Congresso e base de apoio parlamentar, não seria possível obter a variabilidade necessária para a base de dados bimestral desta pesquisa.

\section{2) Ano Eleitoral (Dummies T0, T1, T2 e T3)}

O objetivo principal é captar o efeito do ciclo eleitoral sobre as receitas estimadas e respectivos desvios de execução. Seguindo Golden e Poterba (1980) e Blais e Nadeau (1992), o ciclo eleitoral pode ser desmembrado em um grupo de 4 variáveis dummies, cada uma delas 
representando uma fase específica do ciclo. Dessa forma, T0 é uma dummy que assume valor 1 nos anos de eleição presidencial e 0 nos demais casos, T1 é a dummy para o primeiro ano pós-eleitoral, T2 é uma dummy que assume valor 1 no segundo ano após a eleição e T3 é a dummy para o ano pré-eleitoral.

A ideia subjacente ao uso dessas dummies é que o governante estimula a economia no ano eleitoral e, logo após a eleição, adota medidas restritivas para reduzir a dívida, mantendo os gastos sobre controle e a tributação mais elevada nos anos intermediários, voltando a adotar medidas expansionistas na eleição seguinte. O cenário esperado para o ano eleitoral, portanto, é de aumento do desvio de execução orçamentária, com redução do saldo fiscal, haja vista que o governo tende a reduzir a tributação e aumentar as transferências e os gastos públicos. Para executar essa política expansionista, os gastos maiores precisam estar previstos no orçamento, tais quais as receitas necessárias para fazer frente a estes gastos. Assim, testaremos a hipótese de que a receita estimada e os respectivos erros de execução são maiores (para o positivo ou para o negativo) no ano eleitoral e menores nos anos intermediários (T1, T2 e T3).

3) DCMO: Dummy que representa o apoio da Comissão Mista do Orçamento na manutenção da proposta orçamentária encaminhada pelo Executivo ao Congresso. Assume valor 1 nos anos em que o relator do proposta orçamentária era do mesmo partido do governo e 0 nos demais anos.

Algumas dummies serão utilizadas para captar a importância de fatos e eventos internos ocorridos ao longo do período sob análise, além de políticas econômicas que possam ajudar a explicar os desvios de execução.

DMATRIZ: Dummy com valor 1 para o período a partir do primeiro bimestre de 2011 até o último bimestre de 2013, cujo objetivo é captar a influência da chamada "Nova Matriz Macroeconômica" sobre o planejamento e desvio de execução orçamentário.

DCRISE08: Dummy com valor 1 para o período a partir do terceiro bimestre de 2008 até o terceiro bimestre de 2010, com o objetivo de captar os efeitos das medidas expansionistas adotadas pelo Governo Federal por ocasião dos efeitos negativos da crise econômica internacional que estava em vigor. 
DMATRIZ08: Dummy com valor 1 para o período a partir do terceiro bimestre de 2008 até o quarto bimestre de 2014. Esta dummy contempla as duas dummies anteriores, Dmatriz e Dcrise08 além de estender o prazo de análise, com o objeito de avaliar os efeitos conjuntos das políticas expansionistas e das previsões otimistas adotadas a partir de 2008 e interrompidas ao final de 2014, após as eleições presidenciais. ${ }^{64}$

\section{4 \\ Análise Econométrica: Aspectos Metodológicos}

\subsection{1}

\section{Testes de Raiz Unitária}

A análise de regressão envolvendo dados de séries temporais requer que as séries sejam estacionárias. Séries estacionárias são aquelas que apresentam suas médias e variâncias constantes ao longo do tempo, e covariância entre dois períodos de tempo dependendo exclusivamente da distância ou defasagem entre os dois períodos, e não do período no tempo em que a covariância é calculada ${ }^{65}$. A condição de estacionariedade é violada quando os dados apresentam tendência ascendente ou descendente no tempo, podendo levar ao problema da regressão espúria ${ }^{66}$ identificado por Granger e Newbold (1974), como resultado da inadequação do uso da econometria clássica quando as variáveis são não estacionárias.

O primeiro passo da análise de regressão envolvendo dados de séries temporais consiste em verificar a estacionariedade das séries. Um dos testes mais frequentes na literatura para fazer essa verificação é o teste Dickey-Fuller Aumentado (ADF). A aplicação do teste ADF

\footnotetext{
${ }^{64}$ Também foi testada uma dummy com valor 1 de partir de janeiro de 2007 até o final de 2015 para captar possíveis efeitos do Plano de Aceleração do Crescimento (PAC) sobre o desvio de execução da receita. Essa dummy não apresentou significância estatística em nenhuma das equações estimadas e, portanto, não foi incluída em nossa análise.

${ }^{65}$ Esta definição diz respeito à estacionariedade fraca. O conceito de estacionariedade forte requer que a distribuição conjunta de todas as observações seja a mesma, independente da origem t na escala de tempo (GREENE, 2002). Neste trabalho, o conceito de estacionariedade fraca será suficiente.

${ }^{66} \mathrm{O}$ problema da regressão espúria origina-se na existência de elevada autocorrelação nos resíduos gerados por modelos de regressão convencionais, podendo-se aceitar a existência de relação entre variáveis geradas por processos inteiramente independentes. Assim, um alto valor do $\mathrm{R}^{2}$ não pode ser considerado uma evidência de existência de relação entre as séries na presença de uma tendência estocástica nas séries (GRANGER e NEWBOLD, 1974).
} 
envolve a determinação correta do modelo que será utilizado, isto é, a inclusão ou não de termos deterministas. Três modelos são possíveis: o modelo 1 sem tendência determinística e sem intercepto; o modelo 2 que inclui intercepto e o modelo 3, mais completo, que tem intercepto e tendência. Conforme exposto em Enders (1995), sem conhecer o processo gerador da série, não sabemos com certeza se estamos incluindo os regressores deterministas apropriados. A inclusão de parâmetros desnecessários reduz os graus de liberdade e o poder do teste, definido como a probabilidade de se rejeitar uma hipótese nula falsa. A redução do poder do teste implica que se pode aceitar incorretamente a hipótese de que a série apresenta uma raiz unitária. Por outro lado, se os termos deterministas forem indevidamente retirados, o poder do teste cai à zero. Regressores extras também aumentam o valor absoluto dos valores críticos conduzindo o pesquisador ao erro de rejeitar erroneamente a hipótese de raiz unitária. Nesta tese, adotamos o procedimento proposto por Enders (1995) de começar o teste a partir do modelo 3 mais completo, realizando os referidos testes para o intercepto e a tendência. Nas situações em que não for possível rejeitar a hipótese nula de insignificância da tendência, o teste é realizado com o modelo 2 e, por fim, nos casos em que este modelo também se mostrar incorreto, adota-se o modelo 1.

Outra importante questão relativa ao teste ADF é a definição do número de defasagens que será utilizado no teste. Se o número de defasagens $(p)$ for muito pequeno, pode não ser suficiente para eliminar a correlação serial nos resíduos e o teste será viesado. Se $p$ for muito alto, o poder do teste se reduzirá. Para fundamentar a escolha de $p$, Enders (1995) sugere que o teste ADF seja realizado com um número maior de defasagens. Caso esta defasagem seja insignificante, deve-se repetir a estimativa com $n-1$ defasagens, sucessivamente, até encontrar aquela que seja estatisticamente diferente de zero e, para a qual, não haja nenhuma evidência de correlação serial nos resíduos gerados pelo teste estimado com as defasagens escolhidas. Nesta pesquisa, além do critério de maior significância da última defasagem e da análise da autocorrelação dos resíduos, a definição do número de defasagens foi complementada pelos critérios de informação de Akaike, de Schwarz e de Hannan-Quinn. Para a escolha final do número de defasagens, levamos em conta qual era a defasagem que estava sendo indicada pelo maior número de critérios, condicionada ao fato que a defasagem escolhida garantisse resíduos não autocorrelacionados.

A fim de mitigar os efeitos do baixo desempenho do teste ADF (MADDALA e KIM, 1998), realizamos também o teste Dickey-Fuller-GLS (DF-GLS), proposto por Elliott, Rothenberg e 
Stock (1996). Como o teste ADF possui baixa potência na presença de termos deterministas, o teste DF-GLS é visto como uma alternativa de potência mais elevada quando estes termos estão presentes. Os resultados dos testes ADF e DF-GLS são apresentadas na Tabela 18. Há algumas diferenças nos resultados dos dois testes. O teste ADF indica que a variável CAMBIO_DESVIO é estacionária, enquanto as demais apresentam raiz unitária. Por outro lado, o teste DF-GLS aponta 6 variáveis como sendo estacionárias: REC_DESVIO; PIB_DESVIO; DESP_DESVIO; SELIC_DESVIO; IGPDI_PREV; POLITIC.

Tabela 18 - Teste Dickey-Fuller Aumentado (ADF) e DF-GLS

\begin{tabular}{|c|c|c|c|c|c|c|c|}
\hline \multirow{3}{*}{ Variável } & \multicolumn{4}{|c|}{ Teste Dickey-Fuller Aumentado } & \multicolumn{3}{|c|}{ Teste DF-GLS } \\
\hline & \multirow[b]{2}{*}{ Defasagens } & \multirow[b]{2}{*}{ Modelo } & \multirow{2}{*}{$\begin{array}{c}\tau \\
\text { calculado }\end{array}$} & \multirow[b]{2}{*}{ Decisão } & \multicolumn{2}{|c|}{$\tau$ calculado } & \multirow[b]{2}{*}{ Decisão } \\
\hline & & & & & $\begin{array}{c}\text { Modelo } \\
3\end{array}$ & $\begin{array}{c}\text { Modelo } \\
2\end{array}$ & \\
\hline REC_DESVIO & 19 & 1 & -0.96 & $\mathbf{I}(\mathbf{1})$ & -3.55 & -2.94 & $\mathbf{I}(\mathbf{0})$ \\
\hline PIB_DESVIO & 17 & 1 & -0.83 & I(1) & -3.45 & -3.16 & $\mathbf{I}(\mathbf{0})$ \\
\hline DSLP_DESVIO & 12 & 1 & -0.63 & $\mathrm{I}(1)$ & -1.85 & -1.24 & $\mathrm{I}(1)$ \\
\hline IPCA_DESVIO & 12 & 1 & -0.63 & $\mathrm{I}(1)$ & -1.09 & -0.64 & $\mathrm{I}(1)$ \\
\hline IGPDI_DESVIO & 4 & 1 & -1.30 & $\mathrm{I}(1)$ & -2.43 & -1.70 & $\mathrm{I}(1)$ \\
\hline DESP_DESVIO & 12 & 1 & -1.59 & I(1) & -3.18 & -1.94 & $\mathbf{I}(\mathbf{0})$ \\
\hline CAMBIO_DESVIO & 0 & 1 & -4.06 & $\mathbf{I}(\mathbf{0})$ & -2.82 & -2.04 & I(1) \\
\hline SELIC_DESVIO & 6 & 1 & -1.53 & I(1) & -3.57 & -4.00 & $\mathbf{I}(\mathbf{0})$ \\
\hline CAMBIO_PREV & 0 & 1 & 0.41 & $\mathrm{I}(1)$ & $-0,68$ & $-0,85$ & $\mathrm{I}(1)$ \\
\hline REC_PREV & 18 & 1 & -1.64 & I(1) & -2.07 & -1.77 & $\mathbf{I}(\mathbf{1})$ \\
\hline PIB_PREV & 0 & 1 & $-1,17$ & $\mathrm{I}(1)$ & -1.56 & -1.05 & $\mathrm{I}(1)$ \\
\hline DESP_PREV & 17 & 2 & 2.62 & $\mathrm{I}(1)$ & -1.23 & -0.96 & $\mathrm{I}(1)$ \\
\hline DLSP-PREV & 13 & 1 & -1.50 & $\mathrm{I}(1)$ & -2.40 & $-0,23$ & $\mathrm{I}(1)$ \\
\hline IGPDI_PREV & 7 & 1 & -1.48 & I(1) & -3.65 & -3.40 & $\mathbf{I}(\mathbf{0})$ \\
\hline IPCA_PREV & 12 & 1 & 0.70 & $\mathrm{I}(1)$ & -2.17 & -2.03 & $\mathrm{I}(1)$ \\
\hline SELIC__PREV & 5 & 1 & -1.23 & $\mathrm{I}(1)$ & -2.05 & -1.33 & $\mathrm{I}(1)$ \\
\hline CRB & 4 & 1 & -0.26 & $\mathrm{I}(1)$ & -1.50 & -1.24 & $\mathrm{I}(1)$ \\
\hline POLITIC & 5 & 1 & -1.23 & $\mathbf{I}(\mathbf{1})$ & -7.96 & -1.98 & I $(0)$ \\
\hline
\end{tabular}

NOTAS: Modelo 3:com constante e com tendência; Modelo 2: com constante. Modelo 1: sem termos deterministas. Valores críticos tabelados teste ADF, modelo 1: 1\%: -2.59; 5\%: $-1.94 ; 10 \%:-1.61$. Modelo 2: $1 \%$ : $-3.52 ; 5 \%:-2.90 ; 10 \%$ : -2.59 . Valores críticos tabelados teste DF-GLS, modelo 3: $1 \%$ : $-3.64 ; 5 \%$ : $-3.08 ; 10 \%$ : 2.79. Modelo 2: $1 \%$ : $-2.59 ; 5 \%:-1.94 ; 10 \%:-1.61$.

Para complementar os resultados dos dois testes anteriores, realizamos também o teste de NG e Perron (MZ-GLS). Conforme exposto em Bueno (2008), além da questão do poder, o teste de raiz unitária sofre do problema do tamanho do teste e NG e Perron (2001) apresentaram soluções para melhorar o tamanho do teste. ${ }^{67}$ Em relação à sensibilidade dos testes de raiz

\footnotetext{
${ }^{67}$ Segundo Gujarati e Porter (2011), problemas de tamanho estão relacionados à probabilidade de se cometer o erro do tipo I, isto é, probabilidade de rejeitar uma hipótese nula quando ela é verdadeira. No caso do teste ADF, é a probabilidade de dizer que a série é estacionária quando ela não é.
} 
unitária ao tamanho da defasagem autoregressiva $p$, NG e Perron (2001) realizaram modificações nos tradicionais critérios de informação de Akaike, Schwarz e Hannan-Quinn e desenvolveram uma técnica dependente da amostra para selecionar a defasagem ótima (BUENO, 2008). Os resultados do teste de NG-Perron estão apresentados na Tabela 19.

Tabela 19 - Teste Ng-Perron

\begin{tabular}{|c|c|c|c|c|c|c|}
\hline \multirow{2}{*}{ Variável } & \multicolumn{3}{|c|}{ Modelo 3 - Constante e Tend. } & \multicolumn{3}{|c|}{ Modelo 2 - Constante } \\
\hline & $\mathbf{M Z t}$ & Defasagens & Decisão & $\mathbf{M Z t}$ & Defasagens & Decisão \\
\hline REC_DESVIO & -1.41 & 12 & $\mathbf{I}(\mathbf{1})$ & -6.77 & 18 & $\mathbf{I}(\mathbf{0})$ \\
\hline PIB_DESVIO & -0.67 & 18 & $\mathrm{I}(1)$ & -0.44 & 18 & $\mathrm{I}(1)$ \\
\hline DSLP_DESVIO & -0.69 & 6 & $\mathrm{I}(1)$ & -0.56 & 6 & $\mathrm{I}(1)$ \\
\hline IPCA_DESVIO & -1.01 & 12 & $\mathrm{I}(1)$ & -0.002 & 12 & $\mathrm{I}(1)$ \\
\hline IGPDI_DESVIO & -1.14 & 6 & $\mathrm{I}(1)$ & -0.81 & 6 & $\mathrm{I}(1)$ \\
\hline DESP_DESVIO & -0.94 & 5 & $\mathrm{I}(1)$ & -0.28 & 12 & $\mathrm{I}(1)$ \\
\hline CAMBIO_DESVIO & -2.51 & 0 & $\mathrm{I}(1)$ & -1.91 & 0 & $\mathrm{I}(1)$ \\
\hline SELIC_DĒSVIO & -0.99 & 6 & $\mathrm{I}(1)$ & 0.06 & 8 & $\mathrm{I}(1)$ \\
\hline CAMBIO_PREV & -0.68 & 0 & $\mathrm{I}(1)$ & -0.84 & 0 & $\mathrm{I}(1)$ \\
\hline REC_PREV & --0.93 & 11 & $\mathbf{I}(\mathbf{1})$ & -24.53 & 11 & $\mathbf{I}(\mathbf{0})$ \\
\hline PIB_PREV & $-1,50$ & 0 & $\mathbf{I}(\mathbf{1})$ & -1.01 & 0 & $\mathbf{I}(\mathbf{0})$ \\
\hline DESP_PREV & -9.72 & 14 & $\mathbf{I}(\mathbf{O})$ & 1.20 & 14 & I(1) \\
\hline DLSP-PREV & -2.43 & 1 & $\mathrm{I}(1)$ & $-0,18$ & 2 & $\mathrm{I}(1)$ \\
\hline IGPDI_PREV & -2.10 & 0 & I(1) & -2.01 & 0 & $\mathbf{I}(\mathbf{0})$ \\
\hline IPCA_PREV & -2.05 & 0 & $\mathrm{I}(1)$ & -1.93 & 0 & $\mathrm{I}(1)$ \\
\hline SELIC__PREV & -1.95 & 0 & $\mathrm{I}(1)$ & -1.29 & 0 & $\mathrm{I}(1)$ \\
\hline $\mathrm{CRB}$ & -1.55 & 1 & $\mathrm{I}(1)$ & -1.00 & 0 & $\mathrm{I}(1)$ \\
\hline POLITIC & -4.50 & 0 & $\mathbf{I}(\mathbf{0})$ & -1.89 & 2 & $\mathbf{I}(\mathbf{1})$ \\
\hline
\end{tabular}

Notas:

Valores críticos modelo 3 com tendência: $1 \%=-3,42 ; 5 \%=-2,91$ e $10 \%=-2,62$.

Valores críticos modelo 2 com constante: $1 \%=-2,58 ; 5 \%=-1,98$ e $10 \%=-1,62$.

Comparando o resultado dos três testes, a variável IGPDI_PREV foi a que apresentou maior divergência entre eles. Foi considerada integrada de ordem um pelo ADF e pelo teste NGPerron, no modelo com tendência determinista, e estacionária pelo teste DF-GLS e pelo teste NG-PERRON no modelo 2 sem tendência. Para fundamentar a decisão final, utilizamos a análise do correlograma da série e, em função dessa análise, assumimos que a variável integrada de ordem 1. Dessa maneira, os resultados dos testes de raiz unitária nos indicam que todas as variáveis utilizadas nessa pesquisa possuem uma raiz unitária e, portanto, são integradas de ordem 1. 
Realizados os testes de raiz unitária e, considerando que as variáveis possuem a mesma ordem de integração, podemos verificar se as séries se cointegram. A interpretação econômica da cointegração é que se duas (ou mais) variáveis possuem uma relação de equilíbrio de longo prazo, então mesmo que as séries possam exibir tendência estocástica, elas irão mover-se juntas no tempo e a diferença entre elas será estacionária. Sinteticamente, a análise de cointegração busca uma relação estacionária entre variáveis não estacionárias e indica a existência de uma relação de equilíbrio de longo prazo entre as variáveis.

De acordo com Hamilton (1994), se houver pelo menos uma relação de cointegração entre as variáveis, o estimador de Mínimos Quadrados Ordinários é superconsistente ${ }^{68}$. Em outras palavras, podemos utilizar as séries em nível e estimar os parâmetros da regressão através de Mínimos Quadrados ${ }^{69}$. Os testes utilizados para avaliar se as séries se cointegram serão os testes do Traço e do Máximo Autovalor do Procedimento de Johansen. Os resultados estão expressos na Tabela 20.

Tabela 20 - Teste de Cointegração de Johansen

\begin{tabular}{l|l|c|c|c|c|c}
\hline \multirow{2}{*}{$\begin{array}{l}\text { Vetores de } \\
\text { Cointegração }\end{array}$} & \multicolumn{3}{|c|}{ Teste do Traço } & \multicolumn{3}{c}{ Teste do Máximo Autovalor } \\
\cline { 2 - 7 } & Estatística & Valor crítico 5\% & P-valor & Estatística & Valor Crítico 5\% & P-valor \\
\hline Nenhum & 561.0738 & NA & NA & 107.0608 & NA & NA \\
Pelo menos 1 & $454.0130^{*}$ & 334.9837 & 0.0000 & $94.08205^{*}$ & 76.57843 & 0.0007 \\
Pelo menos 2 & $359.9310^{*}$ & 285.1425 & 0.0000 & $75.98110^{*}$ & 70.53513 & 0.0145 \\
Pelo menos 3 & $283.9499^{*}$ & 239.2354 & 0.0001 & 58.20353 & 64.50472 & 0.1756 \\
Pelo menos 4 & $225.7463^{*}$ & 197.3709 & 0.0009 & 55.83249 & 58.43354 & 0.0884 \\
Pelo menos 5 & $169.9138^{*}$ & 159.5247 & 0.0120 & 45.01107 & 52.36261 & 0.2317 \\
Pelo menos 6 & 124.9028 & 125.6154 & 0.0552 & 35.73760 & 46.23142 & 0.4138 \\
\hline
\end{tabular}

FONTE: Resultados da pesquisa.

NOTA: NA: não avaliado

O teste de Johansen indica que as variáveis se cointegram. Com 5\% de significância podemos rejeitar a hipótese nula de que não há cointegração em favor da hipótese alternativa de que há cointegração. O Teste do Traço indica que há 5 vetores de cointegração, enquanto o teste do

\footnotetext{
${ }^{68}$ Segundo Stock (1987) a convergência do estimador de Mínimos Quadrados para seu valor verdadeiro com variáveis cointegradas ocorre mais rápido do que em regressões com variáveis estacionárias.

${ }^{69}$ A adoção desse procedimento foi baseado em Baffes et alli (1999) que o adotou em um estudo sobre determinação da taxa de câmbio real de equilíbrio.
} 
Máximo Autovalor indica que há 2 vetores de cointegração representando a relação de longo prazo entre as variáveis analisadas. ${ }^{70}$ Sendo as séries cointegradas, podemos trabalhar com as séries em nível e partir de um modelo de MQO para estimar a regressão.

\subsubsection{Teste de Endogeneidade}

Precisamos testar se há regressores endógenos, isto é, se há alguma variável explicativa correlacionada com os termos de erro da regressão. Se este for o caso, os estimadores de Mínimos Quadrados Ordinários serão viesados e será necessário utilizar o método de variáveis instrumentais para resolver esse problema. No entanto, como expresso por Murray (2006) é difícil encontrar variáveis que sejam instrumentos válidos, uma vez que as variáveis que tem um efeito sobre as endógenas também podem afetar diretamente a variável dependente. Instrumentos inválidos podem gerar estimadores ainda mais viesados do que os estimadores de MQO, embora Murray (2006) afirme que todos os instrumentos possuem certo grau de invalidade e que o pesquisador precisa decidir o quanto de invalidade irá tolerar no instrumento. Outro problema é que o instrumento escolhido pode ser fraco no sentido que é fracamente correlacionado com a variável endógena. Instrumentos fracos não superam o viés dos estimadores de MQO e geram estimadores com significância estatística errada, mesmo para grandes amostras. Como expresso por Bound et alli (1995), utilizar instrumentos fracos resulta em uma situação na qual a cura é pior que a doença. Dessa maneira, precisamos avaliar se há indícios de endogeneidade nos modelos estimados e se os instrumentos escolhidos são válidos e fortes.

Seguindo a literatura sobre desvios de execução, realizamos o teste de endogeneidade de Durbin-Wu-Hausman para testar possível simultaneidade entre os desvios de execução da receita e os desvios do PIB. Este teste compara os parâmetros da regressão estimada por Mínimos Quadrados (MQO) com aqueles resultantes das estimações por Mínimos Quadrados em Dois Estágios (MQ2E). Se as estimativas geradas por MQO e por MQ2E não diferirem de forma estatisticamente significante, conclui-se pela aceitação da hipótese nula de que o

\footnotetext{
${ }^{70}$ A divergência entre os resultados dos dois testes pode ser um problema de amostras pequenas. Quando isso ocorre, Enders (1995) sugere utilizar o teste de Máximo Autovalor.
} 
regressor testado é exógeno. Também seguindo a literatura, utilizamos como instrumento para o desvio do PIB a própria variável defasada em um, dois e três períodos (AFONSO e CARVALHO, 2013; AFONSO e SILVA, 2012; MEROLA e PEREZ, 2012).

A Tabela 21 apresenta os resultados dos testes de endogeneidade realizados para todas as regressões estimadas para a equação do desvio de execução (Equação 1). Ao todo, apresentaremos resultados de 4 regressões, com diferentes combinações de variáveis explicativas, relativas à Equação 1. A variável testada como exógena foi o desvio do PIB. Em todas as equações estimadas não foi possível rejeitar a hipótese nula de ausência de endogeneidade.

Tabela 21 - Teste de Durbin-Wu-Hausman - Equação do Desvio de Execução

\begin{tabular}{ccccc}
\hline Modelo & Variável testada & Diferença Estatística-J & Prob. & Conclusão \\
\hline 1 & PIB_DESVIO & 1.533411 & 0.2156 & Não rejeitamos H0 \\
2 & PIB_DESVIO & 1.397274 & 0.2372 & Não rejeitamos H0 \\
3 & PIB_DESVIO & 0.654787 & 0.4184 & Não rejeitamos H0 \\
4 & PIB_DESVIO & 0.263020 & 0.6081 & Não rejeitamos H0 \\
\hline
\end{tabular}

FONTE: Resultados da pesquisa.

A ausência de endogeneidade apontada pelo teste de de Durbin-Wu-Hausman pode ter sido causada pela escolha dos instrumentos utilizados na regressão por MQ2E. Para verificar se os instrumentos são fracos, utilizamos o teste de Stock e Yogo (2005) e a estatística F de Cragg e Donald (1993).

Supondo que os instrumentos não sejam fracos e sejam válidos, o viés do estimador de variáveis instrumentais (IV) será menor que o viés de MQO. No caso de um único instrumento, Staiger e Stock (1997) sugerem aceitar a hipótese nula de instrumento fraco quando a estatística F proposta por Cragg e Donald (1993) for menor que 10. Porém, Stock e Yogo (2005) mostraram que a regra de ouro proposta por Staiger e Stock (1997) não é sempre suficiente. O teste proposto por Stock e Yogo (2005) indica o maior viés relativo ao estimador de MQ2E comparado ao MQO que o pesquisador está disposto a aceitar. O teste responde à pergunta se é possível rejeitar a hipótese nula de que o viés relativo máximo devido aos instrumentos é de, por exemplo, 20\%, $10 \%$ ou 5\%. Os valores críticos do teste foram calculados com base no método de IV utilizado, no número de instrumentos, no número de 
regressores endógenos incluídos e no quanto de viés e distorção de tamanho o pesquisador está disposto a aceitar. Considerando-se o viés máximo do MQO tolerado, rejeita-se a hipótese nula de instrumentos fracos quando a estatística F de Cragg e Donald superar os valores críticos tabelados por Stock e Yogo (2005). O resultado do teste de instrumento fraco é apresentado na Tabela 22:

Tabela 22 - Teste de Instrumento Fraco

Modelos Estimados

\begin{tabular}{lllll} 
& \multicolumn{1}{c}{$\mathbf{1}$} & $\mathbf{2}$ & $\mathbf{3}$ & $\mathbf{4}$ \\
\hline Estatística F de Cragg-Donald & 23.11232 & 21.74369 & 16.30930 & 17.90431 \\
\hline Valores Críticos de Stock-Yogo (viés) & $5 \%: 13.91$ & $10 \%: 9.08$ & $20 \%: 6.46$ & $30 \%: 5.39$ \\
Valores Críticos de Stock-Yogo (tamanho) & $10 \%: 22.30$ & $15 \%: 12.83$ & $20 \%: 9.54$ & $25 \%: 7.80$ \\
\hline
\end{tabular}

Fonte: Resultados da pesquisa.

Podemos rejeitar a hipótese nula de instrumento fraco para todos os modelos, com viés em relação ao MQO menor que 5\% para os quatro modelos estimados e com distorção de tamanho menor que $10 \%$ para o modelo 1 e menor que $15 \%$ para os demais modelos. Portanto, o desvio do PIB defasado (em um, dois e três períodos) pode ser considerado um bom instrumento para o desvio do PIB. Porém, como o teste de endogeneidade mostrou, não há indícios de que essa variável seja endógena, de forma que podemos prosseguir a análise sem adotarmos modelos de regressão com variáveis instrumentais.

\section{5 Análise dos Determinantes do Desvio de Execução}

Estimamos quatro modelos diferentes para a equação do desvio de execução (Equação 1). Em cada modelo inserimos gradativamente as variáveis explicativas, iniciando pelas variáveis econômicas e excluindo em cada regressão as variáveis não consideradas significativas. As variáveis explicativas incluídas em cada um dos modelos estimados são as seguintes: 
Modelo 1:

$$
\begin{aligned}
R E C_{D E S I O}= & \beta_{0}+\beta_{1} \text { PIB }_{\text {DESVIO }}+\beta_{2} \text { DESP } P_{D E S V I O}+\beta_{3} \text { DESP }_{\text {PREV }}+\beta_{4} \text { SELIC }_{\text {DESVIO }} \\
& +\beta_{5} \text { DLSP }_{\text {DESVIO }}+\beta_{6} D L S P_{-} P R E V
\end{aligned}
$$

Modelo 2:

$$
\begin{aligned}
R E C_{\text {DESVIO }}= & \beta_{0}+\beta_{1} \text { PIB }_{\text {DESVIO }}+\beta_{2} \text { DESP }_{\text {DESVIO }}+\beta_{3} \text { DESP }_{\text {PREV }}+\beta_{4} \text { SELIC }_{\text {DESVIO }} \\
& +\beta_{5} \text { DLSP }_{\text {DESVIO }}+\beta_{6} D L S P_{P R E V}+\beta_{7} T 0+\beta_{8} T 1+\beta_{9} C R B
\end{aligned}
$$

Modelo 3:

$$
\begin{aligned}
R E C_{\text {DESVIO }}= & \beta_{0}+\beta_{1} \text { PIB }_{\text {DESVIO }}+\beta_{2} \text { DESP } P_{D E S V I O}+\beta_{3} D E S P_{P R E V}+\beta_{4} R E C_{P R E V} \\
& +\beta_{5} \text { SELIC }_{D E S V I O}+\beta_{6} D L S P_{D E S V I O}+\beta_{7} I G P D I_{D E S V I O}+\beta_{8} T 0+\beta_{9} T 1 \\
& +\beta_{10} C R B+\beta_{11} \text { DMATRIZ }
\end{aligned}
$$

Modelo 4:

$$
\begin{aligned}
R E C_{D E S V I O}= & \beta_{0} P_{\text {IB }} B_{\text {DESIO }}+\beta_{1} \text { PIB }_{\text {PREV }(-1)}+\beta_{2} \text { DESP } \\
& +\beta_{4} \text { RESVIO } \\
& +\beta_{3} \text { DESEV } \\
& +\beta_{5} I P C A_{\text {DESVIO }}+\beta_{6} \text { POLITIC }+\beta_{7} D C M O+\beta_{8} T 1 \\
&
\end{aligned}
$$

Cada um desses 4 modelos foi estimado através de 3 métodos de regressão diferentes. A motivação para realizar 3 regressões para cada um dos 4 modelos surgiu da necessidade de corrigir problemas de heterocedasticidade e correlação serial identificados, respectivamente, pelo teste de White e pelos testes de Durbin-Watson e Breusch-Godfrey (teste LM). Segundo Wooldridge (2012), o efeito negativo da correlação serial sobre os erros-padrão e a eficiência dos estimadores são maiores do que os efeitos da heterocedasticidade. Sob correlação serial nos resíduos, os estimadores de MQO continuam lineares, não viesados, consistentes e assintoticamente normais, mas não são mais eficientes, as variâncias estimadas são viesadas.

Se a autocorrelação não causa viés nos coeficientes estimados, mas impacta os erros-padrão, faz sentido adotar um método de estimação que mantenha os coeficientes inalterados e corrija os erros-padrão. Dessa maneira, para corrigir tanto a autocorrelação quanto a heterocedasticidade, o primeiro método de estimação utilizado foi o de Mínimos Quadrados Ordinários (MQO) com correção dos erros-padrão pela matriz de variância e covariância 
robusta à autocorrelação e heterocedasticidade (HAC) de Newey-West. Em função das limitações dos erros-padrão de Newey-West para pequenas amostras (MÜLLER, 2014), os 4 modelos também foram estimados por meio de dois outros métodos para correção da heterocedasticidade e autocorrelação.

O segundo método adotado foi o procedimento iterativo de Cochrane-Orcutt. Assumimos que o termo de erro apresenta uma estrutura autoregressiva de primeira ordem do tipo $\mu_{t=} \rho \mu_{t-1}+\varepsilon_{t}$ e incluímos o termo $\mathrm{AR}(1)$ na lista de variáveis independentes da regressão. ${ }^{71}$ O teste LM de autocorrelação de primeira ordem (Breusch-Godfrey) indica que a inclusão do termo autoregressivo foi suficiente para corrigir a autocorrelação. A autocorrelação também foi corrigida para ordens superiores, conforme os resultados apresentados nas Tabelas 23 e 24 mostradas na próxima subseção. Em função da rejeição da hipótese nula de homocedasticidade apontada pelo Teste de White, a regressão via método de Cochrane-Orcutt também foi corrigida para heterocedasticidade nos resíduos através dos estimadores da matriz variância-covariância de White.

Na terceira regressão de cada modelo, utilizamos a sugestão de Granger e Newbold (1974) e estimamos a equação com as primeiras diferenças das séries. Granger e Newbold (1974) alertaram para o problema da regressão espúria ao lidar com séries não estacionárias e/ou altamente autocorrelacionada. De acordo com Granger e Newbold (1974), a presença de autocorrelação indica que a equação tem erro de especificação. Em geral, esse erro ocorre devido a combinação das seguintes possibilidades: i) omissão de variáveis relevantes; ii) inclusão de variáveis irrelevantes; iii) resíduos autocorrelacionados. As recomendações usuais, segundo esses autores, são: a) a inclusão de uma variável dependente defasada; ou b) a utilização da primeira diferença das variáveis envolvidas na equação; ou ainda, c) assumir uma forma autoregressiva de primeira ordem para os resíduos da equação. Embora Granger e Newbold (1974) acreditem que qualquer um desses métodos irá aliviar o problema geral, também alertam para o fato de que a autocorrelação poderá não ser completamente removida.

\footnotetext{
${ }^{71}$ Procedimento semelhante foi adotado por Afonso e Silva (2012) em artigo sobre os erros de previsão de Portugal.
} 


\subsubsection{Resultados das Regressões: Equação do Desvio de Execução}

No primeiro modelo, incluímos todos os desvios de previsão das variáveis explicativas econômicas uma a uma e os valores previstos da despesa e da dívida líquida do setor público, descartando aquelas que não se mostraram significativas. Ao final, as variáveis econômicas com significância estatística foram o desvio do PIB (PIB_DESVIO), o desvio da despesa (DESP_DESVIO), a previsão da despesa (DESP_PREV), o desvio da Selic (SELIC_DESVIO) e da Dívida Líquida (DLSP_DESVIO), a dívida prevista (DLSP_PREV) e a constante.

A primeira regressão (A.1) foi realizada pelo método dos MQO utilizando os estimadores de erros-padrão consistentes para heterocedasticidade e autocorrelação de Newey-West. Os resultados sugerem que os desvios de execução da receita podem ser explicados pelos erros de projeção de outras variáveis. O coeficiente do Desvio do PIB apresentou o sinal esperado e significativo. As estimativas indicam que para cada ponto percentual que a taxa de crescimento do produto se distancia do crescimento projetado, a receita realizada se desvia da receita prevista em $\mathrm{R} \$ 6.92$ bilhões. Esse valor é considerável, haja vista que, de acordo com a LDO 2015, para cada $1 \%$ de variação no PIB, a arrecadação das receitas administradas pela Secretaria da Receita Federal (exceto previdenciárias) varia 0,63\%.

Resultados semelhantes foram apresentados pelo desvio de execução da despesa e desvio de execução da taxa Selic. Um aumento de $\mathrm{R} \$ 1.00$ bilhão na diferença entre a despesa realizada e a despesa prevista, eleva o desvio da receita em $\mathrm{R} \$ 0.70$ bilhão. Em relação ao desvio da Selic, para cada 1 ponto percentual de desvio entre a taxa de juros prevista e a efetiva, a receita realizada se distanciará da prevista em $\mathrm{R} \$ 5.61$ bilhões. Em relação ao desvio da dívida líquida, a relação é negativa. Para cada ponto percentual que a DLSP/PIB se distancia do valor previsto, há uma queda no desvio de execução da receita, ou seja, se a dívida supera a previsão, o desvio entre receita realizada e receita prevista diminui. Variações na previsão da relação DLSP/PIB também possuem efeitos negativos sobre o desvio da receita. Em outras palavras, se há uma expectativa de que a dívida irá aumentar, a diferença entre receita realizada e receita prevista cai, o que pode indicar um comportamento mais realista por parte das previsões fiscais diante de um aumento da dívida. Os resultados também indicam que mudanças de $\mathrm{R} \$ 1.00$ bilhão na previsão das despesas reduz o desvio da receita em $\mathrm{R} \$ 0.33$ 
bilhão, um valor baixo quando comparado aos efeitos das demais variáveis contidas na regressão. Era de se esperar que despesas esperadas maiores resultassem em maior previsão de receita e, portanto, maior desvio, já que a previsão teria que ser mais otimista para acomodar a maior despesa. Porém, o sinal indica um efeito inverso. Uma possível explicação é que despesas esperadas maiores podem indicar a necessidade de elevar a arrecadação e dessa forma, levar à convergência da receita realizada com a receita prevista.

A inclusão do termo autoregressivo (AR) de primeira ordem na regressão B.1 do Modelo 1 manteve os sinais dos coeficientes inalterados, mas elevou a magnitude dos mesmos e modificou os desvios-padrão. A exceção foi o desvio da taxa Selic que deixou de ser estatisticamente significante. O coeficiente do termo autoregressivo pode ser considerado significante a $1 \%$. O teste LM de Breusch-Godfrey e a estatística $d$ de Durbin-Watson indicam que a inclusão do termo $\mathrm{AR}(1)$ corrigiu a correlação serial nos resíduos. No entanto, a estatística de Jarque-Bera indicou que os resíduos dessa regressão não apresentam uma distribuição normal. Adicionalmente, em função da manutenção da heterocedasticidade, os erros-padrão da regressão foram corrigidos por meio dos estimadores robustos de White.

Na terceira regressão do modelo 1 (regressão C.1), utilizamos a primeira diferença das séries. As variáveis PIB_DESVIO, DESP_PREV, DLSP_DESVIO e DLSP_PREV continuaram significativas a $1 \%$ e mantiveram os mesmos sinais das regressões anteriores, embora a magnitude dos coeficientes ficasse maior. A variável DESP_DESV deixou de ser estatisticamente significante na explicação da primeira diferença do desvio da receita. $\mathrm{O}$ mesmo aconteceu com a primeira diferença da taxa de juros Selic. Quanto à análise dos resíduos da regressão, as séries na primeira diferença corrigiram a autocorrelação. Novamente os erros-padrão da regressão foram corrigidos por meio dos estimadores robustos de White. Quanto à distribuição dos resíduos, não foi possível aceitar a hipótese de normalidade.

Em termos de ajuste do modelo 1, a regressão B.1, com termo autoregressivo de primeira ordem, apresentou o menor valor para a soma dos quadrados dos resíduos, menores valores para os critérios de informação e o menor valor para a soma dos resíduos da regressão, que se espera seja o mais próximo possível de zero. Os resultados estão expostos na Tabela 23. 
Tabela 23 - Determinantes dos Desvios de Execução da Receita

\begin{tabular}{|c|c|c|c|c|c|c|}
\hline \multirow{3}{*}{ Variáveis Explicativas } & \multicolumn{6}{|c|}{ Variável Dependente: Desvio da Receita - REC_DESVIO } \\
\hline & \multicolumn{3}{|c|}{ Modelo 1} & \multicolumn{3}{|c|}{ Modelo 2 } \\
\hline & $\begin{array}{c}\text { A.1 } \\
\text { MQO }^{\prime 1}\end{array}$ & $\begin{array}{c}\text { B.1 } \\
\operatorname{AR}(\mathbf{1})^{\prime 2}\end{array}$ & $\begin{array}{c}\text { C.1 } \\
1^{\mathrm{a}} \text { Dif. }^{/ 2}\end{array}$ & $\begin{array}{c}\text { A.2 } \\
\text { MQO }^{\prime 1}\end{array}$ & $\begin{array}{c}\mathbf{B . 2} \\
\mathbf{A R}(\mathbf{1})^{\prime 2}\end{array}$ & $\begin{array}{c}\text { C.2 } \\
1^{\mathrm{a}} \text { Dif. }^{/ 2}\end{array}$ \\
\hline Constante & $\begin{array}{r}562.1240 * * * * \\
(103.1784)\end{array}$ & $\begin{array}{r}622.8635 * * * \\
(175.1209)\end{array}$ & & $\begin{array}{r}847.0463 * * * \\
(156.6636)\end{array}$ & $\begin{array}{r}716.7823 * * * * \\
(193.1148)\end{array}$ & \\
\hline PIB_DESVIO & $\begin{array}{r}6.9178 * * * \\
(2.8095)\end{array}$ & $\begin{array}{r}11.2303 * * * * \\
(2.9786)\end{array}$ & $\begin{array}{r}9.5846 * * * \\
(3.1331)\end{array}$ & $\begin{array}{r}5.9916 * * * \\
(1.7183)\end{array}$ & $\begin{array}{r}8.9047 * * * * \\
(2.3179)\end{array}$ & $\begin{array}{r}9.3475 * * * \\
(3.0482)\end{array}$ \\
\hline DESP_DESVIO & $\begin{array}{r}0.7005 * * * \\
(0.1762)\end{array}$ & $\begin{array}{r}0.4863 * * * \\
(0.1220)\end{array}$ & $\begin{array}{r}0.2201 \\
(0.1986)\end{array}$ & $\begin{array}{r}0.5296 * * * \\
(0.1650)\end{array}$ & $\begin{array}{r}0.4530 * * * \\
(0.1419)\end{array}$ & $\begin{array}{r}0.2147 * * * \\
(0.2043)\end{array}$ \\
\hline DESP_PREV & $\begin{array}{r}-0.3343 * * * \\
(0.0505)\end{array}$ & $\begin{array}{r}-0.3474 * * * \\
(0.0989)\end{array}$ & $\begin{array}{r}-0.5092 * * * * \\
(0.1371)\end{array}$ & $\begin{array}{r}-0.4355 * * * \\
(0.0624)\end{array}$ & $\begin{array}{r}-0.3829 * * * * \\
(0.0968)\end{array}$ & $\begin{array}{r}-0.5193 * * * \\
(0.1267)\end{array}$ \\
\hline SELIC_DESVIO & $\begin{array}{r}5.6088 * * * \\
(1.4420)\end{array}$ & $\begin{array}{l}-2.8158 \\
(2.1531)\end{array}$ & $\begin{array}{l}-2.2831 \\
(2.2541)\end{array}$ & $\begin{array}{r}5.5699 * * * \\
(1.2730)\end{array}$ & $\begin{array}{r}-1.3826 \\
(1.4879)\end{array}$ & $\begin{array}{r}-2.1816 * * * \\
(2.3210)\end{array}$ \\
\hline DLSP_DESVIO & $\begin{array}{r}-6.9623 * * * \\
(1.4165)\end{array}$ & $\begin{array}{r}-8.0230 * * * * \\
(2.0454)\end{array}$ & $\begin{array}{r}-8.4131 * * * \\
(2.1918)\end{array}$ & $\begin{array}{r}-12.6203 * * * \\
(2.1218)\end{array}$ & $\begin{array}{r}-9.7847 * * * \\
(2.5579)\end{array}$ & $\begin{array}{r}-8.6842 * * * \\
(2.0454)\end{array}$ \\
\hline DLSP_PREV & $\begin{array}{r}-8.7186 * * * * \\
(1.7048)\end{array}$ & $\begin{array}{r}-9.8609 * * * \\
(2.7835)\end{array}$ & $\begin{array}{r}-11.4961 * * * * \\
(3.3224)\end{array}$ & $\begin{array}{r}-12.5155 * * * \\
(2.199881)\end{array}$ & $\begin{array}{r}-10.7671 * * * * \\
(2.8353)\end{array}$ & $\begin{array}{r}-11.9406 * * * * \\
(3.4942)\end{array}$ \\
\hline T0 & & & & $\begin{array}{r}28.9612 * * * * \\
(10.34911)\end{array}$ & $\begin{array}{r}19.6519 \\
(14.9965)\end{array}$ & $\begin{array}{r}2.4816 * * * \\
(4.3582)\end{array}$ \\
\hline $\mathrm{T} 1$ & & & & $\begin{array}{l}18.5191 * * \\
(7.199963)\end{array}$ & $\begin{array}{r}5.7246 \\
(8.1831)\end{array}$ & $\begin{array}{r}-2.9937 * * * \\
(5.2982)\end{array}$ \\
\hline CRB & & & & $\begin{array}{r}-0.2962 * * \\
(0.112202)\end{array}$ & $\begin{array}{r}-0.1572 \\
(0.1243)\end{array}$ & $\begin{array}{r}-0.0447 * * * \\
(0.0918)\end{array}$ \\
\hline $\mathrm{AR}(1)$ & & $\begin{array}{r}0.7625 * * * \\
(0.0571)\end{array}$ & & & $\begin{array}{r}0.6860 * * * \\
(0.0923)\end{array}$ & \\
\hline $\mathrm{R}^{2}$ & 0.802542 & 0.891687 & 0.694090 & 0.852451 & 0.899332 & 0.698788 \\
\hline $\mathrm{R}^{2}$ ajustado & 0.787155 & 0.881578 & 0.674226 & 0.834505 & 0.885350 & 0.666225 \\
\hline Soma Quadrado Resíd. & 44007.93 & 24116.28 & 26855.91 & 32884.63 & 22414.18 & 26443.45 \\
\hline Durbin-Watson & 0.869202 & 2.114829 & 2.102763 & 1.093170 & 1.959340 & 2.068707 \\
\hline Soma Resíd. Regressão & 23.90673 & 17.93183 & 18.67560 & 21.08049 & 17.64392 & 18.90354 \\
\hline Akaike Inform. Crit. & 9.265852 & 8.702450 & 8.761856 & 9.045916 & 8.701546 & 8.818668 \\
\hline Schwarz Crit. & 9.468420 & 8.935591 & 8.936712 & 9.335299 & 9.022115 & 9.080952 \\
\hline Hanna-Quinn Crit. & 9.347283 & 8.796113 & 8.832103 & 9.162246 & 8.830332 & 8.924039 \\
\hline $\begin{array}{l}\text { F-statistic } \\
\text { Prob(F-statistic) }\end{array}$ & $\begin{array}{r}52.15925 \\
0.0000 \\
\end{array}$ & $\begin{array}{r}88.20579 \\
0.0000 \\
\end{array}$ & & $\begin{array}{r}47.50296 \\
0.00000 \\
\end{array}$ & $\begin{array}{r}64.32226 \\
0.00000 \\
\end{array}$ & \\
\hline $\begin{array}{l}\text { Jarque-Bera } \\
\text { Prob. }\end{array}$ & $\begin{array}{l}0.656080 \\
0.720334 \\
\end{array}$ & $\begin{array}{r}140.8433 \\
0.0000 \\
\end{array}$ & $\begin{array}{r}72.10504 \\
0.00000 \\
\end{array}$ & $\begin{array}{l}6.584740 \\
0.037166 \\
\end{array}$ & $\begin{array}{r}69.04344 \\
0.0000 \\
\end{array}$ & $\begin{array}{r}56.37601 \\
0.00000 \\
\end{array}$ \\
\hline $\begin{array}{l}\text { Breusch-Godfrey LM } \\
\text { test }\end{array}$ & & & & & & \\
\hline Prob. Chi-2 (1) & 0.0000 & 0.2140 & 0.2608 & 0.0001 & 0.6244 & 0.3218 \\
\hline Prob. Chi-2 (2) & 0.0000 & 0.4021 & 0.4543 & 0.0004 & 0.7150 & 0.5019 \\
\hline Prob. Chi-2 (6) & 0.0001 & 0.5619 & 0.4450 & 0.0139 & 0.5766 & 0.5357 \\
\hline White Test - Prob. Chi-2 & 0.0004 & 0.0017 & 0.0074 & 0.0093 & 0.1422 & 0.0669 \\
\hline
\end{tabular}

Notas: Erros-padrão entre parênteses. /1Desvios-padrão robustos a autocorrelação e heterocedasticidade através dos estimadores da matriz variância-covariança HAC de Newey-West. ${ }^{12}$ Corrigido para heterocedasticiade nos resíduos através dos estimadores da matriz variância-covariância consistentes com heterocedasticidade de White. $* * *, * * \mathrm{e} *$ representam, respectivamente, $1 \%, 5 \%$ e $10 \%$ de significância.

No modelo 2, inserimos as dummies relativas aos anos eleitorais e pré-eleitorais e testamos possíveis combinações destas variáveis com as variáveis econômicas. As variáveis que se mostraram estatisticamente significantes e foram incluídas na regressão de MQO foram as 
dummies T0 e $\mathrm{T} 1$ e a variável $\mathrm{CRB}^{72}$ que representa o índice internacional de preços de commodities.

O modelo 2 foi estimado seguindo o mesmo roteiro do modelo 1: regressão A.2) MQO com erros-padrão consistentes para heterocedasticidade e autocorrelação de Newew-West. Regressão B.2: MQO com inclusão do termo autoregressivo AR(1) e erros-padrão consistentes para heterocedasticidade de White. Regressão C.2: MQO com séries na primeira e erros-padrão consistentes para heterocedasticidade de White.

Na primeira regressão do modelo 2, as dummies eleitorais T0 e T1 apresentaram significância estatística e valores elevados dos coeficientes. O coeficiente do ano eleitoral (T0) sugere que durante o período das eleições há uma elevação no desvio de execução da receita em magnitude superior aos efeitos do desvio do PIB e do desvio da dívida. A dummy T1 que representa o ano pós-eleições apresentou significância estatística, porém o sinal está invertido em relação ao esperado pela teoria. Era de se esperar que, terminado o pleito, o governo adotasse políticas mais restritivas e orçamentos com previsões mais realistas, reduzindo o desvio entre receita realizada e receita prevista. No que se refere à variável CRB, o coeficiente estimado apresentou significância estatística e sinal coerente com o esperado, porém o valor do coeficiente é baixo, 0.3 . Os resultados sugerem que um aumento no valor das commodities internacionais reduz o desvio de execução da receita. A explicação para isso é que a elevação do preço das commodities eleva a receita arrecadada pelo país e, dada a receita prevista, reduz o desvio entre arrecadação e previsão. Este resultado corrobora a análise realizada no capítulo anterior, no qual identificamos que o período em que o preço das commodities internacionais estava em alta durante o Governo Lula, coincide com o período de elevação nas receitas efetivas e baixo desvio de execução.

$\mathrm{Na}$ regressão B.2, com o termo autoregressivo de primeira ordem, as variáveis SELIC_DESVIO e CRB e as dummies T0 e T1 não apresentaram significância estatística na explicação do desvio da receita. As demais variáveis mantiveram seus sinais e significância. Os testes de autocorrelação e de heterocedasticidade mostraram que esses problemas foram resolvidos com a inclusão do termo $\operatorname{AR}(1)$.

\footnotetext{
${ }^{72}$ Também testamos o índice de commodities brasileiro IC-BR, do Banco Central, porém este não se mostrou significativo em nenhuma das regressões apresentadas.
} 
Na regressão C.2, em primeira diferença, todas as variáveis inseridas na regressão mostraramse significativas. Porém, duas delas tiveram o sinal invertido em relação à análise realizada para a regressão A.2. O desvio da taxa Selic passou a indicar que um aumento na diferença entre Selic efetiva e Selic prevista reduz a diferença entre receita realizada e receita prevista. A oscilação do sinal desta variável, conforme muda o método de estimação, põe em dúvida as conclusões que possam ser tiradas a esse respeito. Adicionalmente, a dummy T1 também teve seu sinal alterado, convergindo para o que diz a teoria, isto é, que no ano pós-eleição o governo tende a executar uma política fiscal mais restritiva e um orçamento menos otimista, resultando em um desvio de execução menor. O índice de commodity internacional (CRB), embora tenha mantido o sinal negativo e a significância estatística a $1 \%$, apresentou um coeficiente bastante reduzido de -0.05 , indicando um efeito muito baixo sobre o desvio da receita.

Nos dois modelos testados, a constante mostrou-se significativa a $1 \%$ e com elevada magnitude, em comparação à magnitude dos demais coeficientes. Uma possível justificativa para esses resultados decorre dos problemas apresentados pela base de dados, de autocorrelação, heterocedasticidade e não-normalidade dos resíduos.

No modelo 3 (Tabela 24), a regressão estimada contemplou a inclusão das variáveis REC_PREV, IGPDI_DESVIO e da dummy DMATRIZ, representando o período em que a Nova Matriz Macroeconômica foi adotada na economia. Por outro lado, a variável DLSP_PREV foi retirada da estimação por não ter sido possível rejeitar a hipótese de que seu parâmetro era estatisticamente igual a zero. Os resultados indicam que o desvio do PIB possui um efeito positivo sobre o desvio da receita, ou seja, uma surpresa no crescimento do PIB leva a um aumento no desvio de execução da receita. O coeficiente estimado da variável PIB_DESVIO foi o maior em comparação a todas as demais regressões (modelos 1, 2 e 4), um aumento no desvio do PIB eleva o desvio da receita em R \$ 16.19. Lembrando que, da forma como é calculado, o desvio de execução da receita pode ser positivo ou negativo. Portanto, um desvio maior pode ser resultado de um deslocamento positivo do PIB realizado em relação ao previsto, ou um deslocamento negativo (espera-se que o PIB acima do esperado resulte em Receita acima da prevista e, portanto, um desvio de execução positivo). 
O desvio da despesa, a despesa prevista e o desvio da DLSP/PIB tem efeitos positivos sobre o desvio da receita. O sinal do coeficiente do desvio da dívida líquida apresentou sinal positivo, diferente da avaliação e dos resultados encontrados para essa mesma variável nas regressões anteriores 1 e 2. Por sua vez, a receita prevista, o desvio da taxa Selic e o desvio do IGP-DI apresentam coeficientes significativos e com sinal negativo, indicando que um aumento nessas variáveis reduz o desvio de execução da receita. No caso da receita prevista, as evidências encontradas apontam que um aumento nessa variável leva a uma queda no desvio de execução de 0.74. Beetsma et alli (2013) encontraram um resultado com características semelhantes para a Holanda e justificaram dizendo que previsões mais ambiciosas de arrecadação reduzem a aderência do governo ao plano fiscal, o que iria elevar o desvio de execução. Sob essas considerações, o sinal da variável REC_PREV deveria ser positivo. Em relação ao IGP-DI, uma elevação na diferença entre inflação efetiva e inflação esperada, reduz o desvio de execução. Esse efeito pode resultar do impacto da inflação sobre a arrecadação publica, já que em termos nominais, há uma elevação da receita arrecadada.

A variável CRB apresentou sinal positivo e significante, contrariando o resultado encontrado nas regressões do modelo 2. A dummy T0 para os anos eleitorais não se mostrou significativa, contrariando as teorias dos ciclos políticos-econômicos. Conforme exposto em Nakaguma e Bender (2010), a evidência empírica internacional é a de que os déficits orçamentários são maiores em anos eleitorais, enquanto a arrecadação de impostos diminui. Dessa forma, esperaríamos que os desvios de execução aumentassem no ano do pleito eleitoral. O resultado encontrado, porém, pode ser reflexo da base de dados pequena, autocorrelacionada e heterocedástica. Por outro lado, a dummy T1, para o ano pós-eleições, mostrou-se significativa e com o sinal esperado, indicando uma redução do desvio de receita após a fase das eleições.

No que se refere às dummies representativas dos eventos e medidas de políticas econômicas, a dummy DMATRIZ indicou um elevado efeito positivo e significativo. Os resultados sugerem que o desvio de execução da receita se elevou durante a fase da Nova Matriz Macroeconômica. Por fim, a regressão do Modelo 3 via MQO e estimadores robustos de Newey-West, resultou em resíduos normais e homocedásticos (Regressão A.3). 
Tabela 24- Determinantes dos Desvios de Execução da Receita

\begin{tabular}{|c|c|c|c|c|c|c|}
\hline \multirow{3}{*}{ Variáveis Explicativas } & \multicolumn{6}{|c|}{ Variável Dependente: Desvio da Receita - REC_DESVIO } \\
\hline & \multicolumn{3}{|c|}{ Modelo 3} & \multicolumn{3}{|c|}{ Modelo 4} \\
\hline & $\begin{array}{c}\text { A.3 } \\
\text { MQO }^{\prime 1}\end{array}$ & $\begin{array}{c}\text { B.3 } \\
\operatorname{AR}(1)^{\prime 2}\end{array}$ & $\begin{array}{c}\text { C.3 } \\
1^{\mathrm{a}} \text { Dif. }^{\prime 2} \\
\end{array}$ & $\begin{array}{c}\text { A.4 } \\
\text { MQO }^{11}\end{array}$ & $\begin{array}{c}\mathrm{B} .4 \\
\mathrm{AR}(1)^{\prime 2}\end{array}$ & $\begin{array}{c}\text { C.4 } \\
1^{\mathrm{a}} \text { Dif. }^{\prime 2}\end{array}$ \\
\hline Constante & $\begin{array}{r}33.7158 \\
(20.5013)\end{array}$ & $\begin{array}{r}158.4144 * \\
(80.0311)\end{array}$ & & & & \\
\hline PIB_DESVIO & $\begin{array}{r}16.1883 * * * \\
(3.766695)\end{array}$ & $\begin{array}{r}3.7713 \\
(4.1112)\end{array}$ & $\begin{array}{r}5.1602 \\
(4.7223)\end{array}$ & $\begin{array}{r}7.7827 * * * * \\
(2.3309)\end{array}$ & $\begin{array}{r}7.4976 * * * \\
(2.3998)\end{array}$ & $\begin{array}{r}8.7744 * * * \\
(3.1937)\end{array}$ \\
\hline PIB_PREV(-1) & & & & $\begin{array}{r}4.7062 * * * * \\
(1.6110)\end{array}$ & $\begin{array}{r}0.2584 \\
(0.7136)\end{array}$ & $\begin{array}{r}0.7597 \\
(1.1426)\end{array}$ \\
\hline DESP_DESVIO & $\begin{array}{r}0.7606 * * * * \\
(0.1411)\end{array}$ & $\begin{array}{r}1.0417 * * * * \\
(0.0928)\end{array}$ & $\begin{array}{r}0.9461 * * * \\
(0.1935)\end{array}$ & $\begin{array}{r}0.8705 * * * \\
(0.1365)\end{array}$ & $\begin{array}{r}1.1265 * * * \\
(0.1227)\end{array}$ & $\begin{array}{r}0.9997 * * * * \\
(0.1801)\end{array}$ \\
\hline DESP_PREV & $\begin{array}{r}0.7345 * * * \\
(0.1784)\end{array}$ & $\begin{array}{r}1.0168 * * * \\
(0.0956)\end{array}$ & $\begin{array}{r}0.8903 * * * \\
(0.2174)\end{array}$ & $\begin{array}{r}0.6116 * * * \\
(0.1623)\end{array}$ & $\begin{array}{r}0.8391 * * * * \\
(0.1380)\end{array}$ & $\begin{array}{r}0.8598 * * * * \\
(0.2394)\end{array}$ \\
\hline REC_PREV & $\begin{array}{r}-0.7342 * * * \\
(0.1547)\end{array}$ & $\begin{array}{r}-1.0436 * * * * \\
(0.1076)\end{array}$ & $\begin{array}{r}-0.9786 * * * * \\
(0.1504)\end{array}$ & $\begin{array}{r}-0.6535 * * * \\
(0.1386)\end{array}$ & $\begin{array}{r}-0.7976 * * * * \\
(0.1148)\end{array}$ & $\begin{array}{r}-0.8454 * * * \\
(0.1673)\end{array}$ \\
\hline IPCA_DESVIO & & & & $\begin{array}{l}1.7416 * \\
(0.9591)\end{array}$ & $\begin{array}{r}-3.4885 \\
3.8540\end{array}$ & $\begin{array}{r}-7.3202 \\
(4.9202)\end{array}$ \\
\hline SELIC_DESVIO & $\begin{array}{r}-3.8596 * \\
(1.9772)\end{array}$ & $\begin{array}{r}0.6824 \\
(2.4868)\end{array}$ & $\begin{array}{r}1.5678 \\
(2.6641)\end{array}$ & & & \\
\hline DLSP_DESVIO & $\begin{array}{r}4.1620 * * * * \\
(1.3248)\end{array}$ & $\begin{array}{r}-3.6766 * * \\
(1.6657)\end{array}$ & $\begin{array}{r}-4.9737 * * * * \\
(1.8051)\end{array}$ & & & \\
\hline IGPDI_DESVIO & $\begin{array}{r}-3.1539 * * \\
(1.2580)\end{array}$ & $\begin{array}{r}-0.3884 \\
(1.9214)\end{array}$ & $\begin{array}{r}-1.1780 \\
(2.2205)\end{array}$ & & & \\
\hline POLITIC & & & & $\begin{array}{r}0.0577 * * * * \\
(0.0181)\end{array}$ & $\begin{array}{r}0.0393 * * * \\
(0.0136)\end{array}$ & $\begin{array}{r}0.0445 * * * \\
(0.0154)\end{array}$ \\
\hline DCMO & & & & $\begin{array}{r}-22.7123 * * \\
(9.0236)\end{array}$ & $\begin{array}{l}-22.4202 * \\
(11.7411)\end{array}$ & $\begin{array}{r}-1.3673 \\
(2.9282)\end{array}$ \\
\hline T0 & $\begin{array}{r}17.6944 \\
(10.9179)\end{array}$ & $\begin{array}{r}14.6875 \\
(16.2008)\end{array}$ & $\begin{array}{r}-2.2129 \\
(2.0485)\end{array}$ & & & \\
\hline $\mathrm{T} 1$ & $\begin{array}{r}-14.3356 * * \\
(6.5595)\end{array}$ & $\begin{array}{r}-9.3685 \\
(10.2328)\end{array}$ & $\begin{array}{r}-0.1807 \\
(4.1356)\end{array}$ & $\begin{array}{r}-11.6546 * \\
(6.3968)\end{array}$ & $\begin{array}{r}-26.9125 \\
(17.1088)\end{array}$ & $\begin{array}{r}-3.0639 \\
(4.9270)\end{array}$ \\
\hline CRB & $\begin{array}{r}0.3180 * * * * \\
(0.0801)\end{array}$ & $\begin{array}{r}0.0435 \\
(0.0632)\end{array}$ & $\begin{array}{r}0.0732 \\
(0.0932)\end{array}$ & $\begin{array}{r}0.3076 * * * \\
(0.0493)\end{array}$ & $\begin{array}{l}\text { 0.1614* } \\
(0.0895)\end{array}$ & $\begin{array}{r}0.1962 * \\
(0.1133)\end{array}$ \\
\hline DCRISE08 & & & & $\begin{array}{r}-22.7712 * * * \\
(10.8723)\end{array}$ & $\begin{array}{r}-33.8175 \\
(24.1134)\end{array}$ & $\begin{array}{r}2.6722 \\
(4.7744)\end{array}$ \\
\hline DMATRIZ & $\begin{array}{r}95.7675 * * * \\
(14.2036)\end{array}$ & $\begin{array}{r}70.9239 * * * * \\
(16.9352)\end{array}$ & $\begin{array}{r}3.1232 \\
(3.4086)\end{array}$ & & & \\
\hline DMATRIZ 08 & & & & $\begin{array}{r}85.1701 * * * * \\
(12.0922)\end{array}$ & $\begin{array}{r}62.9690 * * \\
(28.4833)\end{array}$ & $\begin{array}{r}0.4064 \\
(4.2698)\end{array}$ \\
\hline AR (1) & & $\begin{array}{r}0.9588 * * * \\
(0.0310)\end{array}$ & & & $\begin{array}{r}0.9729 * * * \\
(0.0319)\end{array}$ & \\
\hline $\mathrm{R}^{2}$ & 0.863510 & 0.943399 & 0.784750 & 0.908413 & 0.945086 & 0.783479 \\
\hline $\mathrm{R}^{2}$ ajustado & 0.842658 & 0.933697 & 0.754854 & 0.894224 & 0.935536 & 0.749454 \\
\hline Soma Quadrado Resíduos & 30419.76 & 12602.36 & 18896.89 & 20392.24 & 12198.14 & 18993.28 \\
\hline Durbin-Watson & 1.020595 & 1.835724 & 1.869145 & 0.954665 & 2.318760 & 2.076554 \\
\hline Soma Resíduos Regressão & 20.55472 & 13.41766 & 16.20052 & 16.94741 & 13.29604 & 16.47218 \\
\hline Akaike Inform. Crit. & 9.015622 & 8.173929 & 8.530849 & 8.631103 & 8.157270 & 8.642685 \\
\hline Schwarz Crit. & 9.362882 & 8.552783 & 8.851419 & 8.980815 & 8.538823 & 8.992397 \\
\hline Hanna-Quinn Crit. & 9.155218 & 8.326131 & 8.659636 & 8.771598 & 8.310458 & 8.783180 \\
\hline $\begin{array}{l}\text { F-statistic } \\
\text { Prob(F-statistic) }\end{array}$ & $\begin{array}{r}41.41015 \\
0.0000 \\
\end{array}$ & $\begin{array}{r}97.22814 \\
0.0000 \\
\end{array}$ & & & & \\
\hline $\begin{array}{l}\text { Jarque-Bera } \\
\text { Prob. }\end{array}$ & $\begin{array}{l}1.350884 \\
0.509033 \\
\end{array}$ & $\begin{array}{l}323.9209 \\
0.000000 \\
\end{array}$ & $\begin{array}{l}283.0544 \\
0.000000\end{array}$ & $\begin{array}{l}0.366224 \\
0.832675 \\
\end{array}$ & $\begin{array}{l}28.01045 \\
0.000001\end{array}$ & $\begin{array}{l}134.5354 \\
0.000000 \\
\end{array}$ \\
\hline $\begin{array}{l}\text { Breusch-Godfrey LM test } \\
\text { Prob. Chi-2 (1) }\end{array}$ & 0.0000 & 0.4367 & 0.5554 & 0.0000 & 0.1144 & 0.7022 \\
\hline Prob. Chi-2 (2) & 0.0000 & 0.5691 & 0.8400 & 0.0000 & 0.1393 & 0.7082 \\
\hline Prob. Chi-2 (6) & 0.0001 & 0.9504 & 0.0042 & 0.0002 & 0.0204 & 0.0067 \\
\hline White Test - Prob. Chi-2 & 0.2315 & 0.0000 & 0.0555 & 0.2809 & 0.0000 & 0.2453 \\
\hline
\end{tabular}

Notas: Erros-padrão entre parênteses. /1Desvios-padrão robustos a autocorrelação e heterocedasticidade através dos estimadores da matriz variância-covariança HAC de Newey-West. ${ }^{12}$ Corrigido para heterocedasticiade nos resíduos através dos estimadores da matriz variância-covariância consistentes com heterocedasticidade de White. $* * *, * * \mathrm{e}^{*}$ representam, respectivamente, $1 \%, 5 \%$ e $10 \%$ de significância. 
No modelo B.3 com termo autorregressivo, o desvio do PIB deixou de ter significância. O mesmo ocorreu com as variáveis SELIC_DESVIO, IGPDI_DESVIO, CRB e a dummy T1. Adicionalmente, o sinal do desvio da DLSP voltou a indicar que um efeito negativo entre DLSP_DESVIO E REC_DESVIO. A inclusão do termo autoregressivo na estimação do modelo 3 melhorou os indicadores de ajuste do modelo: reduziu a soma do quadrado dos resíduos, reduziu a soma dos resíduos da regressão, reduziu os valores dos critérios de informação e eliminou a autocorrelação serial. Por outro lado, os resíduos passaram a ser heterocedásticos e não normais.

No que se refere à regressão das séries nas primeiras diferenças C.3, os resultados indicaram que a dummy DMATRIZ também deixou de ter significância estatística. O uso das séries em primeira diferença corrigiu a autocorrelação de primeira e segunda ordem, mas não corrigiu a de sexta ordem, por outro lado, a heterocedasticidade foi eliminada com 5\% de significância.

No modelo 4 (Tabela 24), entre as variáveis macroeconômicas, substituímos o desvio do IPCA $^{73}$ no lugar do desvio do IGP-DI e incluímos a previsão do PIB defasada em um período. Em relação às variáveis políticas e às variáveis do grupo INST, aquelas que se mostraram estatisticamente significantes foram a variável POLITIC, a dummy DCMO, a dummy T1 e as dummies DCRISE08 e DMATRIZ08. A constante que já havia sido estatisticamente insignificante no Modelo A.3, continuou apresentando esse mesmo resultado e foi retirada do modelo.

Na regressão A.4 com MQO, a variável PIB_PREV defasada em um período apresentou um sinal positivo e significância estatística a $1 \%$. O resultado indica que uma previsão de aumento na taxa de crescimento do PIB no bimestre anterior, eleva o desvio de execução da receita no período atual em $\mathrm{R} \$ 4.71$. O resultado é coerente, uma vez que a previsão de crescimento econômico eleva a previsão de arrecadação tributária. O desvio do IPCA apresentou significância a 10\% e sinal positivo, indicando que uma taxa de inflação acima da esperada resulta em aumento no desvio de execução da receita em $\mathrm{R} \$ 1.74$. A variável POLITIC que representa o apoio político que o Governo obtém no Congresso, apresentou

\footnotetext{
${ }^{73}$ Além do desvio do IPCA, também testamos a variável DESVIO_IPCA_META, calculada como a diferença entre a Taxa de Inflação Média Esperada Medida pelo IPCA e a Meta Oficial de Inflação. Essa variável capta o quanto a expectativa de inflação contida no orçamento se distancia da meta oficial de inflação. Porém, esta variável não considerada estatisticamente significativa em nenhuma das regressões apresentadas e, portanto, foi retirada da análise.
} 
sinal positivo, porém com um coeficiente com valor bastante reduzido de $\mathrm{R} \$ 0.06$. Esse resultado indica que um aumento no apoio político ao Governo eleva o desvio de execução das receitas. Na verdade, esperar-se-ia que, com maior apoio político, as previsões orçamentárias fossem mais realistas, resultando em um menor desvio de execução da receita. Já a dummy DCMO apresentou um valor negativo, significativo a 5\% e de magnitude elevada. Em coerência com o resultado esperado, os dados indicam que um aumento no apoio que o Governo obtém da CMO se reflete em uma redução no desvio de execução da receita de cerca de $\mathrm{R} \$ 22.71$. A dummy $\mathrm{T} 1$ permaneceu com coeficiente negativo e significante, indicando que o desvio de execução é menor no ano que sucede à eleição.

Em relação às dummies que representam os eventos e políticas econômicas adotadas, a dummy DCRISE08, que representa o período de adoção de medidas expansionistas adotadas pelo Governo Federal em resposta aos efeitos da crise internacional iniciada entre 2007-2008, também apresentou um coeficiente elevado e um valor negativo (-22.77). O resultado é contrário ao esperado, haja vista que a adoção dessas medidas expansionistas coincidiu com o período no qual o desvio de execução da receita começou a aumentar.

Já a dummy DMATRIZ08, que busca captar os efeitos conjuntos das políticas expansionistas adotadas após a crise de 2008 e a partir da introdução da Nova Matriz Macroeconômica, apresentou um sinal positivo e um coeficiente de 85.17, valor bastante elevado em comparação aos coeficientes das demais variáveis. Esse resultado contradiz a dummy DCRISE08 e indica que as medidas expansionistas contribuíram para a elevação do desvio de execução da receita.

Na regressão B.4, com o termo autoregressivo $\mathrm{AR}(1)$, a previsão defasada do PIB deixou de ser significativa. O mesmo ocorreu com o IPCA_DESVIO e com as dummies T1 e DCRISE08. Os coeficientes das demais variáveis não apresentaram mudanças significativas em relação à regressão A.4. No que se refere à regressão C.4, as mudanças ocorridas foram em relação às dummies DCMO e DMATRIZ08 que deixaram de ser estatisticamente significativas.

Em relação às regressões realizadas para o modelo 4, a autocorrelação foi corrigida para a primeira e segunda ordem nas regressões com termo autoregressivo AR(1) e com as variáveis 
em primeira diferença. Porém, a autocorrelação para $6^{\mathrm{a}}$ ordem não foi corrigida. O Teste de White indicou que os resíduos podem ser considerados homocedásticos tanto na regressão A.4 com MQO e variáveis em nível, quanto na regressão com as variáveis diferenciadas, porém, continuam heterocedásticos na regressão com termo $\mathrm{AR}(1)$, lembrando que para os erros-padrão desta regressão foram corrigidos por meio dos estimadores robustos de White.

\subsubsection{Análise dos Resultados: Determinantes da Fase de Planejamento}

Nesta seção, o objetivo é identificar os determinantes do planejamento orçamentário. Em outras palavras, iremos estimar a Equação 2 (reproduzida abaixo) para identificar os determinantes da receita prevista.

$R E C \_P R E V_{t}^{t-1}=\beta_{0}+\beta_{1} M A C R O+\beta_{2} P O L+\beta_{3} I N S T+\varepsilon$

Da mesma forma que fizemos para a equação do desvio de execução da receita, testamos se a variável previsão do PIB (PIB_PREV) pode ser considerada exógena na equação da receita prevista. Os resultados do Teste de Durbin-Wu-Hausman (Tabela 25) indicam que não podemos rejeitar a hipótese nula de que PIB_PREV é uma variável exógena no modelo.

Tabela 25 - Teste de Durbin-Wu-Hausman - Equação Receita Prevista

\begin{tabular}{ccccc}
\hline Equação & Variável testada & Diferença Estatística-J & Prob. & Conclusão \\
\hline 1 & PIB_PREV & 0.178724 & 0.6725 & Não rejeitamos H0 \\
\hline
\end{tabular}

Fonte: Resultados da pesquisa.

Para a realização do Teste de Endogeneidade, estimamos a Equação 2 através do método de Mínimos Quadrados em Dois Estágios utilizando como instrumentos a previsão do PIB defasado em 1, 2 e 3 períodos. Para verificar se os instrumentos utilizados podem ser considerados fracos, utilizamos o teste de Stock-Yogo (Stock e Yogo, 2005) e a estatística F de Cragg e Donald (1993). As evidências indicam que podemos rejeitar a hipótese nula de que os instrumentos são fracos 
Tabela 26 - Teste de Instrumento Fraco

\begin{tabular}{lllll}
\hline Modelo 1: Estatística F de Cragg-Donald & $\mathbf{2 1 . 8 5 5 7 9}$ & & & \\
\hline Valores Críticos de Stock-Yogo (viés) & $5 \%: 13.91$ & $10 \%: 9.08$ & $20 \%: 6.46$ & $30 \%: 5.39$ \\
Valores Críticos de Stock-Yogo (tamanho) & $10 \%: 22.30$ & $15 \%: 12.83$ & $20 \%: 9.54$ & $25 \%: 7.80$ \\
\hline
\end{tabular}

Fonte: Resultados da pesquisa.

De acordo com os resultados apresentados na Tabela 26, podemos rejeitar a hipótese nula de instrumento fraco para a equação da receita prevista, com viés em relação ao MQO menor que $5 \%$ e com distorção de tamanho menor que $15 \%$. Dessa maneira, podemos concluir que a previsão do PIB defasada em um, dois e três períodos pode ser considerada um bom instrumento para a previsão do PIB. Porém, como o teste de endogeneidade mostrou, não há indícios de que essa variável seja endógena, de forma que podemos prosseguir a análise sem adotarmos variáveis instrumentais.

Adotaremos os mesmos métodos de estimação utilizados com a equação de desvio da receita, quais sejam: MQO com os erros-padrão consistentes para heterocedasticidade e autocorrelação (HAC) de Newey-West, seguido por MQO e inclusão do termo autoregressivo $\mathrm{AR}(1)$ e, por fim, MQO com variáveis em primeira diferença.

Por outro lado, diferentemente do que fizemos para a equação do desvio da receita, estamos reportando os resultados de apenas uma regressão realizada para a equação da receita prevista. O motivo é que esta regressão contempla totalmente a combinação das variáveis da nossa base de dados que se mostraram estatisticamente significantes na estimativa por MQO.

A coluna A.1 da Tabela 27 apresenta os resultados relativos à estimação por MQO. Em função da presença de autocorrelação nos resíduos, os desvios-padrão foram corrigidos pelos estimadores robustos de Newey-West. As evidências indicam que o valor previsto das variáveis macroeconômicas contribui para explicar o valor previsto da receita. Esse resultado era esperado, haja vista que a Receita Federal do Brasil utiliza a previsão das mesmas variáveis econômicas que estamos utilizando aqui para construir a previsão oficial de arrecadação.

Os valores previstos do PIB, da despesa e do IGP-DI afetam positivamente a receita prevista. Se há expectativa de aumento do PIB e de aumento da inflação medida pelo IGP-DI, o 
Governo eleva a previsão de arrecadação. ${ }^{74}$ Da mesma maneira, as evidências indicam que um aumento na previsão de despesa também eleva a previsão de arrecadação. Esse resultado indica o efeito que a previsão das despesas orçamentárias exerce sobre a expectativa de arrecadação. ${ }^{75} \mathrm{O}$ resultado indica que uma elevação de $\mathrm{R} \$ 1.00$ na despesa prevista resulta em uma elevação de R\$ 1.06 na previsão de arrecadação. A previsão da Selic e da taxa de câmbio, por outro lado, exercem efeito negativo sobre a receita prevista. Quanto maiores essas taxas, menor será a expectativa de arrecadação.

O desvio de execução da despesa apresentou sinal positivo e significativo, indicando que uma elevação na diferença entre previsão e realização da despesa eleva a receita prevista. A lógica por traz desse resultado é que quanto mais a despesa superar os valores previstos no planejamento orçamentário, maior terá que ser a arrecadação necessária para compensar a elevação dos gastos e garantir o cumprimento da meta de superávit fiscal. Por outro lado, o desvio de execução da receita apresentou um sinal negativo em relação à previsão fiscal, refletindo o fato que arrecadação menor que o esperado, leva a um ajuste para baixo nas expectativas de arrecadação.

A variável CRB que representa o índice de commodities internacionais apresentou um coeficiente positivo e significativo, embora em magnitude pequena de $\mathrm{R} \$ 0.16$, indicando que elevações nos preços das commodities resultam em elevações na receita prevista. $\mathrm{O}$ coeficiente da dummy DCMO indica que quanto maior o apoio ao Governo por parte do relator do orçamento, menor a previsão de arrecadação. A explicação para esse resultado é que a CMO costuma modificar a proposta orçamentária encaminhada pelo Governo, elevando as previsões de receita a fim de acomodar um volume maior de emendas parlamentares. Os resultados do nosso estudo apontam que, quando o relator do orçamento é do mesmo partido do Governo, as receitas previstas se reduzem, ao invés de aumentarem.

A dummy eleitoral T1 também apresentou sinal esperado e coeficiente de elevada magnitude, indicando que no ano imediatamente após o pleito eleitoral que o elegeu, o Governo Federal adota previsões fiscais mais realistas. Por fim, a dummy DMATRIZ apresentou o coeficiente

\footnotetext{
${ }^{74}$ A previsão de inflação medida pelo IPCA foi incluída na regressão, mas foi retirada por não ter se mostrado estatisticamente significante.

${ }^{75}$ Não estamos testando a relação de causalidade entre previsão de despesa e previsão de receita. Porém, diversos trabalhos encontraram evidências de que prevalece no Brasil um modelo fiscal do tipo "gastar e arrecadar", no qual a despesa antecede a arrecadação. Silva et alli (2010) fornecem referências sobre esse assunto.
} 
de maior magnitude na regressão. A interpretação desse coeficiente é que a adoção das políticas relativas à Nova Matriz Macroeconômica resultou em considerável elevação na previsão de arrecadação.

Tabela 27 - Determinantes da Receita Prevista

\begin{tabular}{|c|c|c|c|}
\hline \multirow{2}{*}{ Variáveis Explicativas } & \multicolumn{3}{|c|}{ Variável Dependente: RECEITA PREVISTA - REC_PREV } \\
\hline & $(\mathrm{A} .1) \mathrm{MQO}^{1 /}$ & $($ B.1) AR(1) & (C.1) $1^{\mathrm{a}}$ Dif. $^{/ 2}$ \\
\hline PIB_PREV & $\begin{array}{r}4.0162 * * * \\
(1.2359)\end{array}$ & $\begin{array}{r}5.0560 * * * \\
(0.8929)\end{array}$ & $\begin{array}{r}3.7095 \\
(2.6733)\end{array}$ \\
\hline DESP_PREV & $\begin{array}{r}1.0596 * * * \\
(0.0186)\end{array}$ & $\begin{array}{r}1.0541 * * * * \\
(0.0220)\end{array}$ & $\begin{array}{r}1.0315 * * * \\
(0.1002)\end{array}$ \\
\hline DESP_DESVIO & $\begin{array}{r}0.9633 * * * \\
(0.0809)\end{array}$ & $\begin{array}{r}0.9413 * * * \\
(0.0348)\end{array}$ & $\begin{array}{r}0.8063 * * * \\
(0.1026)\end{array}$ \\
\hline REC_DESVIO & $\begin{array}{r}-0.8190 * * * \\
(0.0607)\end{array}$ & $\begin{array}{r}-0.7734 * * * \\
(0.0392)\end{array}$ & $\begin{array}{r}-0.6651 * * * \\
(0.0782)\end{array}$ \\
\hline DCMO & $\begin{array}{r}-6.8685 * * \\
(3.0083)\end{array}$ & $\begin{array}{r}-3.9943 \\
(4.3249)\end{array}$ & $\begin{array}{r}-0.8694 \\
(1.3240)\end{array}$ \\
\hline DMATRIZ & $\begin{array}{r}48.6322 * * * * \\
(3.9396)\end{array}$ & $\begin{array}{r}52.5665 * * * \\
(8.2724)\end{array}$ & $\begin{array}{r}4.9066 * * \\
(2.3738)\end{array}$ \\
\hline SELIC_PREV & $\begin{array}{r}-3.8517 * * * \\
(0.8915)\end{array}$ & $\begin{array}{r}-3.5862 * * * \\
(1.1686)\end{array}$ & $\begin{array}{r}-4.9227 * * \\
(1.9334)\end{array}$ \\
\hline CAMBIO_PREV & $\begin{array}{r}-40.3851 * * * \\
(6.3466)\end{array}$ & $\begin{array}{r}-37.3262 * * * \\
(6.8202)\end{array}$ & $\begin{array}{r}-32.1274 * * \\
(15.8419)\end{array}$ \\
\hline IGPDI_PREV & $\begin{array}{r}3.5073 * * * \\
(0.4515)\end{array}$ & $\begin{array}{r}3.2692 * * * \\
(0.4683)\end{array}$ & $\begin{array}{r}3.1286 * * * \\
(0.9147)\end{array}$ \\
\hline $\mathrm{T} 1$ & $\begin{array}{r}-24.5201 * * * \\
(3.9828)\end{array}$ & $\begin{array}{r}-21.2192 * * * \\
(5.3193)\end{array}$ & $\begin{array}{r}-1.3795 \\
(1.9405)\end{array}$ \\
\hline $\mathrm{CRB}$ & $\begin{array}{r}0.1634 * * * \\
(0.0547)\end{array}$ & $\begin{array}{r}0.0380 \\
(0.0392)\end{array}$ & $\begin{array}{l}0.06128 \\
(0.0675)\end{array}$ \\
\hline $\begin{array}{l}\mathrm{C} \\
\mathrm{AR}(1)\end{array}$ & $\begin{array}{r}192.5552 * * * \\
(35.3616)\end{array}$ & $\begin{array}{r}217.5347 * * * \\
(37.9655) \\
0.7809 * * * \\
(0.0840)\end{array}$ & \\
\hline $\mathrm{R}^{2}$ & 0.999412 & 0.999707 & 0.957595 \\
\hline $\mathrm{R}^{2}$ ajustado & 0.999322 & 0.999657 & 0.951706 \\
\hline Soma Quadrado Resíd. & 5855.819 & 2850.044 & 7333.768 \\
\hline Durbin-Watson & 0.742710 & 2.123019 & 2.054610 \\
\hline Soma Resíd. Regressão & 9.018360 & 6.380824 & 10.09247 \\
\hline Akaike Inform. Crit. & 7.367966 & 6.687379 & 7.584341 \\
\hline Schwarz Crit. & 7.715225 & 7.066234 & 7.904911 \\
\hline Hanna-Quinn Crit. & 7.507561 & 6.839582 & 7.713128 \\
\hline $\begin{array}{l}\text { F-statistic } \\
\text { Prob(F-statistic) }\end{array}$ & $\begin{array}{l}11125.57 \\
0.000000 \\
\end{array}$ & $\begin{array}{l}19932.51 \\
0.000000 \\
\end{array}$ & \\
\hline $\begin{array}{l}\text { Jarque-Bera } \\
\text { Prob. }\end{array}$ & $\begin{array}{l}0.678053 \\
0.712463 \\
\end{array}$ & $\begin{array}{l}0.730946 \\
0.693868 \\
\end{array}$ & $\begin{array}{l}4.57454 \\
0.000000 \\
\end{array}$ \\
\hline $\begin{array}{l}\text { Breusch-Godfrey LM test } \\
\text { Prob. Chi-2 (1) } \\
\text { Prob. Chi-2 (2) } \\
\text { Prob. Chi-2 (6) }\end{array}$ & $\begin{array}{l}0.0000 \\
0.0000 \\
0.0000 \\
\end{array}$ & $\begin{array}{l}0.3979 \\
0.5459 \\
0.4893 \\
\end{array}$ & $\begin{array}{l}0.6725 \\
0.9133 \\
0.7761 \\
\end{array}$ \\
\hline White Test - Prob. Chi-2 & 0.2772 & 0.0013 & 0.0656 \\
\hline
\end{tabular}


Na coluna 2 estão expressos os resultados da estimação com MQO e o termo AR(1). As principais mudanças nos resultados da regressão referem-se à variável CRB e à dummy DCMO que deixaram de ser estatisticamente significantes na explicação da receita prevista. A inclusão do termo autoregressivo melhorou o ajuste do modelo e também corrigiu a correlação serial, porém não evitou a ocorrência de heterocedasticidade. Em função disso, os desvios-padrão foram corrigidos através dos estimadores robustos de Newey-West.

Assim como ocorreu na equação dos desvios de previsão, novamente a constante apresentou um valor elevado e significante a $1 \%$, nos modelos 1 e 2 , indicando que há determinantes da receita prevista não captadas pelas variáveis incluídas no modelo. Parte desse problema pode ser atribuído aos problemas com a base de dados, tais como a autocorrelação e a heterocedasticidade.

No que se refere ao modelo com variáveis em primeira diferença, a principal mudança observada foi que o PIB previsto deixou de ser significante na explicação da previsão de receita, resultado que destoa do esperado. A dummy eleitoral T1 também perdeu sua importância. As demais variáveis mantiveram seus resultados semelhantes aos analisados nas regressões A.1 e B.1.

Comparando as três regressões apresentadas quanto ao ajuste do modelo e análise dos resíduos, o modelo B.1 estimado por MQO e com o termo AR(1) foi o que apresentou melhor resultado em termos de menor soma de resíduos, menores valores para os critérios de informação, ausência de autocorrelação e normalidade dos resíduos, embora tenha permanecido o problema da heterocedasticidade. 


\section{CONCLUSÕES}

Os dados e as análises realizadas nesta pesquisa nos permitem observar que a previsão fiscal tornou-se menos precisa e os desvios de execução tornaram-se maiores a partir de 2012. A partir da crise internacional em 2008, o Governo Brasileiro passou a adotar subterfúgios contábeis para garantir o cumprimento da meta de superávit primário. A adoção dessas medidas tornou-se mais frequente e com maior impacto sobre a execução orçamentária a partir de 2012, de modo que as previsões contidas na Lei Orçamentária e as metas fiscais presentes na LDO passaram a desempenhar um papel apenas formal, mera exigência legal. Dessa maneira, o planejamento orçamentário deixou de cumprir com sua finalidade de servir como guia das ações políticas e como instrumento de previsibilidade da política fiscal, com isso os planos fiscais perdem credibilidade e a trajetória futura da política fiscal torna-se desconhecida, impactando negativamente as expectativas dos indivíduos.

Com a elevação das despesas inscritas em restos a pagar, o orçamento executado é diferente do orçamento planejado, comprometendo a análise dos desvios de execução. Executam-se despesas de orçamentos anteriores com a receita arrecadada no exercício corrente, criando uma espécie de orçamento paralelo. Essa prática contribui para gerar baixa previsibilidade em relação à execução do orçamento corrente, além de lançar dúvidas a respeito da própria validade do orçamento.

Além dos restos a pagar, o uso frequente de créditos adicionais e a possibilidade de deduzir despesas do PAC da meta de superávit primário também criam um orçamento paralelo, cuja execução difere do orçamento aprovado pelo Congresso. Essas ações não somente prejudicam as investigações a respeito da execução orçamentária, como enfraquecem o papel do Congresso Nacional em relação à alocação dos recursos do orçamento.

Em relação às previsões das variáveis macroeconômicas que influenciam os resultados fiscais, mostramos que ao longo do período analisado houve uma superestimação na taxa de crescimento do PIB. Como vimos, o otimismo em relação ao PIB foi mantido em todas as etapas do processo de planejamento do orçamento, o desvio de previsão do PIB como variável principal na relação de prováveis determinantes dos desvios de execução do orçamento. Dessa 
forma, melhorar a previsão do Governo em relação às variáveis macroeconômicas é um passo importante para reduzir os desvios de execução orçamentários e melhorar o cumprimento do planejamento fiscal.

A análise realizada também evidenciou a influência do preço das commodities nos desvios de execução do orçamento. Observamos que durante os anos em que os preços desses bens estavam em alta, houve um crescimento significativo da arrecadação que permitiu que as previsões otimistas do Governo fossem realizadas. Com o fim do ciclo das commodities, simultaneamente à manutenção de políticas expansionistas e da elaboração de orçamentos com previsões superestimadas, os resultados fiscais se deterioraram. Adicionalmente, verificamos que a elevação dos desvios de execução coincidiu com o período em que se intensificaram as medidas adotadas no âmbito da "Nova Matriz Macroeconômica", conjunto de medidas baseado em juros mais baixos, câmbio desvalorizado e medidas fiscais expansionistas.

Em relação aos fatores políticos, o ano eleitoral não apresentou um efeito significativo sobre os desvios de execução da receita. O efeito do ciclo eleitoral sobre a execução orçamentária parece ocorrer mais intensamente no ano imediatamente após as eleições, sem efeitos nos demais anos do ciclo eleitoral. Esse resultado contraria a evidência empírica da Economia Política, a respeito da existência dos ciclos político-eleitorais. O resultado encontrado, contudo, pode decorrer dos problemas inerentes à construção da base de dados.

Entre as políticas econômicas adotadas, as dummies Dmatriz e Dmatriz08 contribuem para elevar os desvios de execução (menos nos modelos estimados com as variáveis em primeira diferença). Essas dummies referem-se ao período em que prevaleceu a chamada "Nova Matriz Econômica", conjunto de medidas baseado em juros mais baixos, câmbio desvalorizado e medidas fiscais expansionistas. Os resultados indicam que a adoção dessas medidas teve papel importante na elevação dos desvios de execução da receita. Esse resultado alinha-se às análises realizadas no capítulo 5, no qual verificamos que os desvios foram maiores a partir de 2012, quando as medidas da Nova Matriz Econômicas foram intensificadas.

Em relação aos determinantes da receita prevista, as regressões apresentadas atestam a influência da previsão dos fatores macroeconômicos (PIB, câmbio, juros e inflação) sobre a expectativa de arrecadação. Essas variáveis são utilizadas pela Secretaria da Receita Federal 
como parâmetros para o cálculo da previsão das receitas administradas por aquele órgão. Além dessas variáveis, os resultados indicam que a despesa prevista também exerce influência sobre a receita esperada. Da mesma forma, o apoio obtido pelo Governo na Comissão Mista do Orçamento contribuiu para determinar a expectativa de arrecadação.

Tendo em vista o processo orçamentário apresentado no capítulo 3 e os eventos analisados, também podemos concluir que as instituições orçamentárias brasileiras contribuem para elevar os desvios de execução. Isso ocorre porque o processo orçamentário é longo e lento ao passo que o cenário macroeconômico é instável e muda muito rapidamente. Assim sendo, quando a PLDO ou a PLOA são finalmente aprovadas, após um período de longa discussão no Congresso, o cenário macroeconômico vigente já é bastante diferente do cenário para o qual essas propostas foram desenhadas.

Conforme vimos, as análises realizadas nesta pesquisa possuem limitações inerentes às falhas encontradas na construção da base de dados. Dessa forma, os resultados e conclusões apresentados estão condicionados por essas limitações e devem ser interpretados com as devidas ressalvas. Apesar das limitações, a combinação de análise descritiva dos eventos ocorridos ao longo do período investigado com as evidências encontradas por meio da análise econométrica nos permite chegar a algumas conclusões a respeito dos determinantes dos desvios de execução e do planejamento da receita orçamentária. Uma das conclusões que podemos destacar é que as previsões orçamentárias e de crescimento econômico são marcadas por vieses otimistas.

Adicionalmente, os dados e eventos analisados nos permitem inferir que não há um processo de aprendizado do executor de política fiscal ao longo do tempo, sobretudo a partir de 2009, haja vista que os desvios de execução tornaram-se maiores a cada ano ao mesmo tempo em que as expectativas otimistas em relação às variáveis macroeconômicas se mantiveram.

Tendo em vista o crescente papel que a literatura tem atribuído às investigações da política fiscal a partir de dados em tempo real e, considerando-se o papel fundamental da transparência fiscal no ganho de credibilidade da política, extraímos duas sugestões dessa pesquisa. A primeira é que seja disponibilizada uma base de dados oficial, em forma de séries temporais, com as informações das previsões orçamentárias e dos parâmetros macroeconômicos em tempo real. Houve uma iniciativa do Governo nesse sentido com a 
implementação do Prisma Fiscal em que são coletadas e divulgadas expectativas de mercado das principais variáveis fiscais. No entanto, trata-se somente das expectativas de mercado, algo semelhante ao que o Banco Central já disponibiliza em suas séries temporais com base nas informações do Boletim Focus. Além disso, o Prisma Fiscal só disponibiliza dados a partir do segundo semestre de 2015, quando foi lançado. É necessário que seja disponibilizada uma base de dados das previsões e expectativas que embasaram as decisões do Governo em tempo real e em caráter retrospectivo, de modo que haja uma série de tempo longa e estruturada, com metodologia bem definida. Dessa forma, a presente pesquisa poderá ser aprimorada e outros pesquisadores interessados no tema poderão utilizar esses dados para aprofundar em pesquisas correlatas.

Por fim, a segunda sugestão segue a proposta de Jonung e Larch (2004), Beetsma et alli (2013) e Alesina e Perotti (1999), para que a previsão de crescimento do PIB e das demais variáveis macroeconômicas seja atribuída a uma instituição independente do governo para evitar que o otimismo persistente na projeção do crescimento na fase de planejamento do orçamento prejudique os resultados fiscais. No mínimo, seria interessante um debate a respeito do assunto para avaliar os possíveis benefícios oriundos dessa medida. 


\section{REFERÊNCIAS}

AFONSO, A.; CARVALHO, R. (2013). Revenue Forecast Errors in the European Union. Working Papers, WP 02/2013/DE/UECE, Department of Economics, Universidade de Lisboa.

AFONSO, A.; SILVA, J. (2012). The Fiscal Forecasting Track Record of the European Comission and Portugal. Working Papers, WP 37, DE/UECE, Department of Economics, Universidade de Lisboa, ISEG/UTL.

AGHION, P.; MARINESCU, I. (2008). Cyclical Budgetary Policy and Economic Growth: What Do We Learn from OECD Panel Data? In: Acemoglu, D.; Rogoff, K.; Woodford, M. (eds.), NBER Macroeconomics Annual 2007, v. 22, University of Chicago Press.

ALESINA, A. (1987). Macroeconomic policy in a two party system as a repeated game. Quarterly Journal of Economics, 102(3), p. 651-678.

ALESINA, A., PEROTTI, R. (1995). Fiscal expansions and fiscal adjustments in OECD countries. NBER Working Paper Series, n. 5214, August.

ALESINA, A.; PEROTTI, R. (1999). Budget Deficits and Budget Institutions. In: Poterba, J.M., von Hagen, J. (Eds.), Fiscal Institutions and Fiscal Performance. Chicago, Univ. of Chicago Press.

ALESINA, A.; HAUSMANN, R.; HOMMES, R.; STEIN, E. (1999). Budget Institutions and Fiscal Performance in Latin America. Journal of Development Economics, Elsevier, v. 59 (2), p. 253-273, August.

ALESINA, A.; TABELLINI, G. (2005). Why is Fiscal Policy Often Procyclical? NBER Working Paper Series, WP 11600, september.

ALT, J.; LOWRY, R. (1994). Divided government, fiscal institutions and budget deficits: evidencefrom the States. The American Political Science Review, v88, n.4, p.811-828

ALSTON, L.; MUlleR, B.; PEREIRA, C. (2008). Who decides on Public Expenditures? The Political Economy of the Budget Process in Brazil. Mimeo. Disponível em https://www.researchgate.net/publication/253821040_Who_decides_on_Public_Expenditures _The_Political_Economy_of_the_Budget_Process_in_Brazil.Acesso em 29.03.16.

ANNETT, A. (2006). Enforcement and the Stability and Growth Pact: How Fiscal Policy Did and Did Not Change Under Europe's Fiscal Framework, IMF Working Paper, WP/06/116, may, 2006.

AUERBACH, A. J. (1994). The U.S. Fiscal Problem: Where We are, How We Got Here, and Where We're Going. In: Fischer, Stanley and Julio Rotemberg (eds.) NBER Macroeconomics Annual 1994. Cambridge: MIT Press.

AUERBACH, A. J. (1999). On the Performance and Use of Government Revenue Forecasts. National Tax Journal, v. 52, n. 4, p. 765-782, December. 
BAFFES, J.; ELBADAWI, I. A.; O'CONNELL, S. T. (1999) Single-equation Estimation of the Equilibrium Real Exchange Rate. In: HINKLE, L. E.; MONTIEL, P. J. (Ed.). Exchange rate misalignment: concepts and measurement for developing countries. A World Bank Research Publication, Oxford University Press.

BANCO CENTRAL DO BRASIL (2002). Boletim do Banco Central do Brasil, Brasília, v. 38, n. 8. Agosto.

BANCO CENTRAL DO BRASIL (2003). Boletim Anual , Finanças Públicas.

BANCO CENTRAL DO BRASIL (2006). Relatório de Inflação, setembro.

BANCO CENTRAL DO BRASIL (2008). Boletim Anual.

BANCO CENTRAL DO BRASIL (2009a). Relatório de Inflação, setembro.

BANCO CENTRAL DO BRASIL (2009b). Boletim Anual.

BANCO CENTRAL DO BRASIL (2010). Boletim Anual.

BANCO CENTRAL DO BRASIL (2011). Relatório de Inflação, junho.

BEETSMA, R.; JENSEN, H. (2003). Contingent Deficit Sanctions and Moral Hazard with a Stability Pact, Journal of International Economics, v. 61, n. 1. p. 187-208.

BEETSMA, R.; GIULIODORI, M. (2010). Fiscal Adjustment to Cyclical Developments in the OECD: An Empirical Analysis Based on Real-Time Data. Oxford Economic Papers, Oxford University Press, v. 62(3), p. 419-441

BEETSMA, R.; GIULIODORI, M.; WIERTS, P. (2009). Planning to Cheat: EU Fiscal Policy in Real Time, Economic Policy, 24, p. 753-804.

BEETSMA, R.; GIULIODORI, M.; WALSCHOT, M.; WIERTS, P. (2013). Fifty years of fiscal planning and implementation in the Netherlands. European Journal of Political Economy , n. 31, p. 119-138.

BLAIS, A.; NADEAU, R. (1992). The Electoral Budget Cycle. Public Choice, n. 74, p. 389403.

BLANCHARD, O. J. (2004). Fiscal Dominance and Inflation Targeting: Lessons from Brazil. NBER Working Paper, Cambridge: National Bureau of Economic Research, n. 10389, março 2004.

BNDES (2011). Relatório Annual. Disponível em $<$ http://www.bndes.gov.br/SiteBNDES/bndes/bndes_pt/Hotsites/Relatorio_Anual_2011/ > Acesso em 20.03.16.

BOHN, H. (1998), The behavior of US public debt and déficits. Quarterly Journal of Economics, 113, p. 949-963. 
BOUND, J., JAEGER, D.A.; BAKER, R.M. (1995): Problems with Instrumental Variables Estimation when the Correlation Between the Instruments and the Endogenous Explanatory Variable is Weak, Journal of the American Statistical Association 90, 443 - 450.

BRASIL. (2001). Medida Provisória n. 2.211 de 29 de agosto de 2001. Altera dispositivos das Leis n. 9.995, de 25 de julho de 2000, e 10.266, de 24 de julho de 2001, que dispõem sobre as diretrizes para a elaboração das leis orçamentárias de 2001 e 2002, respectivamente. Disponível em <http://www.planalto.gov.br/ccivil_03/mpv/2211.htm> Acesso em 13.01.16.

BRASIL. (2002). Carta do Ministro da Fazenda ao Diretor-Geral do FMI, 29 DE AGOSTO DE 2002. Disponível em <http://161.148.1.43/portugues/fmi/acordofmi.asp> Acesso em 20.03.2016.

BRASIL. (2003). Novo Acordo do Brasil com FMI. Empresa Brasileira de Comunicação. Disponível em <http://memoria.ebc.com.br/agenciabrasil/noticia/2003-11-05/novo-acordodo-brasil-com-fmi-sera-de-us-14-bilhoes $>$ Acesso em 12.02.16.

BRASIL. (2004). Anexo de Metas Fiscais. LDO 2014.

BRASIL. CONGRESSO NACIONAL (2001). Comissão Mista De Planos, Orçamentos Públicos E Fiscalização. Nota Técnica Conjunta n. 8/2001, PLDO/2002, PL n. 4 de 2001CN.

BRASIL. CONGRESSO NACIONAL (2007). Comissão Mista De Planos, Orçamentos Públicos E Fiscalização. Relatório Da Receita - PLN 30/07.

BRASIL. (2012): Anexo de Riscos Fiscais. LDO 2013.

BRASIL. (2013): Anexo de Riscos Fiscais. LDO 2014.

BRASIL. (2014). Relatório de Avaliação de Receitas e Despesas Primárias: $3^{\circ}$ Bimestre de 2014. Secretaria de Orçamento Federal. Brasília. Julho de 2014.

BRASIL. (2010). Secretaria do Tesouro Nacional. Resultado do Tesouro Nacional. Brasília: STN, v. 16, n. 1, janeiro.

BRETSCHNEIDER, S. I.; GORR, W. L.; GRIZZLE, G.; KLAY, E. (1989). Political and Organizational Influences on the Accuracy of Forecasting State Government Revenues. International Journal of Forecasting, n. 5. P. 307-319.

BRETSCHNEIDER, S. I.; GORR, W. L. (1992). Economic, organizational, and political influences on biases in forecasting state sales tax receipts, International Journal of Forecasting, Elsevier, vol. 7(4), march, p. 457-466.

BRÜCK, T.; STEPHAN, A. (2006). Do Eurozone Countries Cheat with their Budget Deficit Forecasts? Kyklos, 59(1), p. 3-15.

BUENO, Rodrigo de Losso Silveira. Econometria de Séries Temporais. São Paulo: Cengage Learning, 2008. 
CAGNIN, R. F.; PRATES, D. M. FREITAS, M. C. P.; NOVAIS, L.F. (2013). A Gestão Macroeconômica do Governo Dilma (2011 e 2012). Novos Estudos n.97, novembro.

CALMFORS, L.; KOPITS, G.; TEULINGS, C. (2010). A New Breed of Fiscal Watchdogs. Euro Intelligence.

CAMPOS, C. V. C. (2009) Previsão da Arrecadação de Receitas Federais: aplicações de modelos de séries temporais para o Estado de São Paulo. 133f. Dissertação (Mestrado). Faculdade de Economia, Administração e Contabilidade da Universidade de São Paulo, Ribeirão Preto.

CASSIDY, G.; KAMLET, M. S.; NAGIN, D. S. (1989). An empirical examination of bias in revenue forecasts by state governments, International Journal of Forecasting, Volume 5, Issue 3, p. 321-33.

CEBOTARI, A.; DAVIS, J.; LUSINYAN, L.; MATI, A.; MAURO, P.; PETRIE, M.; VELLOSO, R. (2008). Fiscal risks: sources, disclosure, and management, Washington, DC: International Monetary Fund.

CEPPARULO, A.; GASTALDI, F.; GIURIATO, L,; SACCHI, A. (2011): Budgetng versus Implementing Fiscal Policy: the Italian case. MPRA Paper.

CIMADOMO, J. (2007). Fiscal Policy in Real Time, CEPII Working Paper, n. 2007-10.

CIMADOMO, J. (2011). Real-time Data and Fiscal Policy Analysis: A Survey of the Literature. Working Paper Series n.1408, European Central Bank, december.

CHATAGNY, F.; SOGUEL, N.C. (2012). Determinants of Tax Revenue Forecasting Errors. Evidence from Swiiss Cantons. WCPCS, fev. 2012

CONJUNTURA ECONÔMICA (2013). O Setor Elétrico e a Concorrência pelo Mercado. Carta do IBRE, Revista Conjuntura Econômica, FGV, Rio de Janeiro, janeiro.

CONTIJO, V. (2010). Orçamento Impositivo, Contingenciamento e Transparência. Cadernos ASLEGIS, n. 39, jan./abr.

CMO. COMISSÃO MISTA DE PLANOS, ORÇAMENTOS PÚBLICOS E FISCALIZAÇÃO. (2003). Nota Técnica Conjunta n. 04/2003. PLDO 2004 - PL N², DE 2003- CN.

COPOM. (2002). Notas da $67^{\mathrm{a}}$ reunião do Comitê de Política Monetária do Banco Central do Brasil, janeiro 2002.

CRAGG, J. G.; DONALD, S. G. (1993) . esting Identifiability and Specification in Instrumental Variables Models. Econometric Theory, v. 9, p. 222-240.

CROUSHORE, D. (2011). Frontiers of Real-Time Data Analysis. Journal of Economic Literature, 49(1): 72-100. 
CROUSHORE, D; STARK, T. (1999). A Real-time Data set for Macroeconomists. Working Paper, n. 99-4. Federal Reserve Bank of Philadelphia, June.

CROUSHORE, D; STARK, T. (2000). A Real-Time Data Set for Macroeconomists: does the data vintage matter for forecasting?', Working Paper, n. 00-6, Federal Reserve Bank of Philadelphia.

CROUSHORE, D; STARK, T. (2001). A Real-time Data set for Macroeconomists. Journal of Econometrics, 105, November, 2001, p. 111-130.

CUSINATO, R. T.; MINELlA, A.; PORTO Jr., S.S. (2010a). Hiato do Produto e PIB no Brasil: uma análise de dados em tempo real. Trabalho para Discussão n. 203, Banco Central do Brasil, Brasília.

CUSINATO, R. T.; MINEllA, A.; PORTO Jr., S.S. (2010b). Produção Industrial no Brasil: uma análise de dados em tempo real. Trabalho para Discussão n. 209, Banco Central do Brasil, Brasília.

DE CASTRO, F.M.; PEREZ, J. J.; RODRIGUES-VIVES, M. (2011). Fiscal Data Revisions in Europe. Banco de Espana Working Paper, n. 1106.

DESCHAMPS, E. (2004) The impact of institutional change on forecast accuracy: A case study of budget forecasting in Washington State, International Journal of Forecasting, Elsevier, vol. 20(4), p. 647-657.

ELLIOT, G.; ROTHENBERG, T. J.; STOCK, J. (1996). Efficient Tests for an Autoregressive Unit Root. Econometrica, v. 64, n. 4, julho, p. 813-836.

ENDERS, W. (1995). Applied Econometric Time Series. John Wiley \& Sons.

EUROPEAN COMMISSION (2004). The Pro-Cyclicality of Fiscal Policy in EMU, Quarterly Report on the Euro Area, Vol. 3.

EUROPEAN COMMISSION (2005). European Economy. Public Finances in EMU, n. 3.

EUROPEAN COMMISSION (2007). European Economy. Public Finances in EMU, n. 3.

FIGUEIREDO, A. M. C.; LIMONGI, F. (2008). Política Orçamentária no Presidencialismo de Coalizão. Rio de Janeiro: Editora FGV.

FORNI, L.; MOMIGLIANO, S. (2005): Cyclical Sensitivity of Fiscal Policies Based on RealTime Data, Applied Economics Quarterly, 50(3), p. 299-326.

FULlERTON Jr., T. M. (1989). A Composite Approach to Forecasting State Government Revenues: Case Study of the Idaho Sales Tax. International Journal of Forecasting, 5, p. 373-380.

GARRATT, A.; VAHEY, S. P. (2006). UK Real-Time Macro Data Characteristic, Economic Journal, 116(509), 119-135. 
GAVIN, M., PEROTTI, R. (1997). Fiscal policy in Latin America. NBER Macroeconomics Annual 12, p. 11- 70 .

GIAMBIAGI, F. (2002). Do Déficit de Metas às Metas de Déficit: a política Fiscal do period 1995-2002. Pesquisa e Planejamento Econômico, v. 32, n. 1, abril 2002.

GIAMBIAGI, F. (2004). A Política Fiscal do Governo Lula em Perspectiva Histórica: Qual é o limite para o aumento do gasto publico? Pesquisa e Planejamento Econômico, n. 27, jun./dez. 2004.

GIAMBIAGI, Fabio. Rompendo com a Ruptura: O Governo Lula. In. Economia Brasileira contemporânea: 1945-2004, Rio de Janeiro Elsevier, 2005.

GIUBERTI, A. C. (2012). Instituições Orçamentárias e Política Fiscal no Brasil: Governo Federal - 1965 a 2010. 260f. Tese (Doutorado) - Universidade de São Paulo.

GOEMINNE, S.; GEYS, B.; SMOLDERS, C. (2005). Political Fragmentation and Projected Tax Income: evidence from Flemish Municipalities. 61 ${ }^{a}$ IIPF-Conference, Korea, August 2005

GOLDEN, D.; POTERBA, J. (1980). The Price of Popularity: the Political Business Cycle Reexamined. American Journal of Political Science, 24, november, 696-714.

GOlinelli, R.; MOMiglianO, S. (2006) Real-time Determinants of Fiscal Policies in the Euro Area: fiscal rules, cyclical conditions and elections. Temi di discussione del Servizio Studi N. 609, December .

GOLOSOV, M.; KING, J. (2002). Tax Revenue Forecasts in IMF-Supported Programs. IMF Working Paper, WP/02/236, December.

GOTTLIEB, J.; GOLDFAJN, I. (2014). Qual foi o impacto do cenário externo sobre o crescimento do Brasil entre 2004 e 2008? Relatório Macro Visão, Itaú, agosto. Disponível em: http://www.itau.com.br/itaubba-pt/analises-economicas/publicacoes/ Acesso em 20 de março de 2016.

GRANGER, C.W.J.; NEWBOLD, P.(1974) Spurious Regressions in Econometrics. Journal of Econometrics, 2 , p. 111-120.

GREENE, W. H. (2002). Econometric Analysis. Prentice Hall, New York.

GREGGIANIN, E. (2005). Processo de Apreciação Orçamentária no Congresso Nacional: Subsídios para a reforma orçamentária.

GUJARATI, D. N.; PORTER, D. C. (2011). Econometria Básica, 5. ed. Bookman: Porto Alegre.

HALLERBERG, M.; von HAGEN, J. (1997). Sequencing and the size of the budget: A reconsideration, CEPR Working Paper, n. 1589. 
HALLERBERG, M.; STRAUCH, R.; von HAGEN, J. (2004). The Design of Fiscal Rules and Forms of Governance in European Union Countries. Working Paper Series, n. 419. European Central Bank, december.

HAMILTON, J. D. Time series analysis. Princeton University Press, 1994.

HIBBS, D.A. (1977). Political Parties and Macroeconomic Outcomes. American Political Science Review 71, p. 1467-1487.

HOLLAND, M.; MORI, M. (2010). Respostas à Crise Financeira de 2008 de uma Perspectiva Brasileira. Texto para Discussão 249, março, FGV-EESP, São Paulo.

HOLM-HADULLA, F. et al. (2012). The Impact of Expenditure Rules on Budgetary Discipline Over the Cycle. Applied Economics, Taylor \& Francis Journals, v. 44(25), p. 3287-3296, September.

INTERNATIONAL MONETARY FUND. (1997). IMF Approves Suplemental Reserve Facility. Press Release N. 97/59, December 17, 1997. Disponível em https://www.imf.org/external/np/sec/pr/1997/PR9759.HTM Acesso: 29.01.16.

JONUNG, L.; LARCH, M. (2004). Improving Fiscal Policy in the EU: The Case for Independent Forecasts, Economic Papers. Commission of the European Communities, 210, July.

KYOBE, A.; DANNINGER, S. (2005). Revenue Forecasting-How is it done? Results from a Survey of Low-Income Countries. IMF Working Paper, WP/05/24.

LANE, P. (1998). On the Cyclicality of Irish Fiscal Policy. The Economic and Social Review, v. 29, n. 1, January, p. 1-16.

LANE, P. (2003). The Cyclical Behaviour of Fiscal Policy: Evidence from the OECD, Journal of Public Economics 87, p. 2661-2675.

LEWIS, J. (2009). Fiscal Policy in Central and Eastern Europe with Real Time Data: cyclicality, inertia and the role of EU accession. DNB Working Paper, n. 214, july.

LEWIS-BECK, M. S., STEGMAIER, M. (2000). Economic Determinants of Electoral Outcomes. Annual Review of Political Sciences 3(1), 183-219.

LLEDÓ, V; POPLAWSKI-RIBEIRO, M. (2013). Fiscal Policy Implementation in SubSaharan Africa. World Development, Vol. 46, pp. 79-91,

MADDALA, G.S.; KIM, I.-M.(1998). Unit Roots Cointegration and Structural Change. Oxford University Press, Oxford.

MARTINS, P. S. F. M. (2012). Previsões Macroeconômicas e Disciplina Orçamental: o caso europeu. Universidade do Porto, Portual, Tese de Doutorado. 
MARTINS, P.; CORREIA, L. (2014). Determinants of Fiscal Slippages in Portuguese Municipalities. Working Papers WP11, DE/UECE, Department of Economics, ISEG, Universidade de Lisboa.

MEROLA, R.; PÉREZ, J. J. (2012). Fiscal Forecast Errors: Governments vs Independent Agencies? Documentos de Trabajo, n. 1233. Banco de España.

MILESI-FERRETI, G. M. (2000). Good, Bad or Ugly? On the Effects of Fiscal Rules with Creative Accounting. IMF Working Paper, WP/00/172, October.

MILESI-FERRETI, G. M.; MORIYAMA, K. (2004). Fiscal Adjustment in EU Countries: a balance sheet approach. IMF Working Paper, WP/04/14, Agosto 2004.

MOCAN, H. N.; AZAD, S. (1995). Accuracy and rationality of state General Fund Revenue forecasts: Evidence from panel data, International Journal of Forecasting, Volume 11, Issue 3, September p.417-427.

MORA, M. (2015). A Evolução do Crédito no Brasil entre 2003 e 2010. IPEA, Texto para Discussão, n. 2022.

MOULIN, L.; WIERTS, P. (2006). How Credible are Multiannual Budgetary Plans in the EU? SSRN Electronic Journal 03/2006; DOI: 10.2139/ssrn.2005228. Disponível em:. http://ssrn.com/abstract=2005228, Acesso em 28.03.2106

MULLER, U.K (2014). HAC Corrections for Strongly Autocorrelated Time Series. American Statistical Association, Journal of Business \& Economic Statistics, July, v. 32, n. 3.

MURRAY, M. P. Avoiding invalid instruments and coping with weak instruments. Journal of Economic Perspectives, v. 20, n. 4, p. 111-132, 2006.

MUSSO, A.; PHILLIPS, S. (2002), "Comparing Projections and Outcomes of IMF-Supported Programs", IMF Staff Papers, v. 49, n. 1.

NADEAU, R.; LEWIS-BECK, M. S.; BÉLANGER, E. (2011). Economics and Elections Revisited. aper presented at the 6th European Consortium for Political Research General Conference, Reykjavik, 25-27 August.

NAKAGUMA, M. Y.; BENDER, S. (2010). Ciclos Políticos e Resultados Eleitorais: um estudo sobre o comportamento do eleitor brasileiro. Revista Brasileira de Economia, vol. 64, n. 1, Rio de Janeiro, jan./mar.

NORDHAUS, W. D. (1975). The Political Business Cycle. The Review of Economic Studies, V. 42, n. 2, April, p. 169-190.

ORPHANIDES, A. (1997). Monetary Policy Rules Based on Real-Time Data, American Economic Review 91, 4, p. 964-985.

PALIS, R. de la R.; RAMOS, R. L. O.; ROBITAILlE, P. (2004). News or Noise? An Analysis of Brazilian GDP Announcements. International Finance Discussion Papers, n. 776. Federal Reserve Board. 
PASSOS, A. P. F.; CASTRO, P. S. C. (2009). O Orçamento e a Dívida Pública Federal. In: SILVA, A. C.; CARVAlHO, L.O.; MEDEIROS, O.L. (orgs.). Dívida Pública: a experiência brasileira. Brasília: Secretaria do Tesouro Nacional: Banco Mundial, 2009.

PASTORE, A. C.; PINOTTI, M.C. (2011). O Câmbio no Brasil: perguntas e respostas. XXIII Fórum Nacional, INAE - Instituto Nacional de Altos Estudos, Rio de Janeiro, maio.

PELLEGRINI, J. A. (2011). Dívida Bruta e Ativo do Setor Público: o que a queda da dívida líquida não mostra? Texto para Discussão n. 95, Núcleo de Estudos e Pesquisa do Senado, junho de 2011.

PEROTTI, R.; KONTOPOUlOS, Y. (2002). Fragmented Fiscal Policy. Journal of Public Economics, 86 (2002), p. 191-222.

PERSON, T.; TABELlinI, G. (1990). Macroeconomic Policy, Credibility and Politics, Harwood Academic Publishers.

PINA, A. (2009). Elusive Counter-cyclicality and Deliberate Opportunism? Fiscal Policy from Plans do Final Outcomes. Banco de Portugal, Economics and Research Department, Working Papers, 6/2009.

PINA, A.; VENES, N. (2011). The Political Economy of EDP Fiscal Forecasts: An Empirical Assessment, European Journal of Political Economy, 27, p. 534-546.

PISCITELLI, R. B. (2006). Orçamento Autorizativo $x$ Orçamento Impositivo. Estudo/ Consultoria Legislativa da Câmara dos Deputados. Brasília: Câmara dos Deputados.

POPLAWSKI-RIBEIRO, M.; RÜLKE, J-C.; (2011). Fiscal Expectations Under the Stability and Growth Pact: Evidence from Survey Data. IMF Working Paper, WP/ 11/48.

POTERBA, J.M. (1994). State Responses to Fiscal Crises: The Effects of Budgetary Institutions and Politics. Journal of Political Economy, v. 102, n. 4, p. 799-821, August.

POTERBA, J.M., von HAGEN, J. (1999). Introduction. In: POTERBA, J.M., von HAGEN, J. (eds.). Fiscal Institutions and Fiscal Performance. NBER, Chicago, Univ. of Chicago Press.

PRATES, D. M.; CUNHA, A. M. (2012). Medidas Macroprudenciais e a Evolução do Crédito em 2011. Indicadores Econômicos FEE, v. 44, n. 1

REZENDE, F. (2009). A Reforma Orçamentária e a Eficiência Fiscal. IPEA, Texto para Discussão, n. 1302.

REZENDE, F.; CUNHA, A. (2003). Orçamento Público e a Transição do Poder. Rio de Janeiro: Editora FGV.

ROGOFF, K. (1990). Equilibrium Political Budget Cycles. American Economic Review, 80, p. 21-36. 
ROGOFF, K.; SIBERT, A. (1988). Elections and Macroeconomic Policy Cycles, Review of Economic Studies, 55, p. 1-16.

ROUBINI, N.; SACHS, J. (1989). Government Spending and Budget Deficits in the Industrial Countries, Economic Policy, Vol. 4, No. 8 (Apr., 1989), pp. 100-132

SANCHES, O.M. (1995). Processo Orçamentário Federal: problemas, causas e indicativos de solução. RAP, Rio de Janeiro, 29(3), jul./set., p. 122-156.

SEDMIHRADSKÁ, L.; CABLA, A. (2013). Budget accuracy in Czech municipalities and the determinants of tax forecasting errors. Ekonomická revue - Central European Review of Economic Issues Volume 16: 197206.

SILVA, C.G.; MACHADO, S. J.; LOPES, D. T.; REBELLO, A. M. (2010). Receitas e Gastos Governamentais: uma análise de causalidade para o caso brasileiro. Economia Aplicada, v. 14 , n. 4, p. 265-275.

SILVA, R. L. M. (2004). A Lei de Responsabilidade Fiscal e a Limitação da Despesa na Administração Pública Federal. R. CEJ, Brasília, n. 26, p. 69-78, julho-setembro.

STAIGER, D.; STOCK, J. H. (1997). Instrumental Variables Regression with Weak Instruments, Econometrica, 65, 557 - 586.

STOCK, J.H. (1987). Asymptotic Properties of Least-Squares Estimators of Cointegrating Vectors, Econometrica 55(5), 1035-56.

STOCK, J. H.; YOGO, M. Testing for Weak Instruments in Linear IV Regression. In: ANDREW, D. W. K.; STOCK, J. H. Identification and inference for econometric models: essays in honor of Thomas Rothenberg. Cambridge: Cambridge University Press, 2005. p. 80-108.

STRAUCH, R. R. (2000). Information and Public Spending: an Empirical Study of Budget Processes in the US States. In: STRAUCH, R. R.; VON HAGEN, J. (eds). Institutions, politics, and fiscal policy. ZEI Studies in European Economics and Law, voI. 2.

STRAUCH, R.; HALLERBERG, M.; von HAGEN, J. (2004). Budgetary Forecasts in Europe - the track record of stability and convergence programmes. ECB, Working Paper Series, n. 307 , february.

TALVI, E.; VEGH, C. (2005). Tax Base Variability and Procyclical Fiscal Policy in Developing Countries. Journal of Development Economics, 78, p.156- 190.

TRIBUNAL DE CONTAS DA UNIÃO. (2012). Relatório de Levantamento de Auditoria. Avaliação da Previsão de Receitas Contina na Proposta Orçamentária da União para o Exercício de 2003. Brasília.

TUFTE, E.R. (1978). Political Control of the Economy. Princeton: Princeton University Press. 
VON HAGEN, J. (1992). Budgeting Procedures and Fiscal Performance in the European Communities. Economic Papers. Commission of the European Communities, 96, October.

VON HAGEN, J. (2010). Sticking to Fiscal Plans: The Role of Institutions, Public Choice, 144(3), p. 487-503.

VON HAGEN, J., HARDEN, I. J. (1994). National budget processes and fiscal performance. European Economy Reports and Studies, 3, p.311-418.

VON HAGEN, J., HARDEN, I. J. (1995). Budget Processes and Commitment to Fiscal Discipline. European Economic Review, 39, p. 771- 779.

VON HAGEN, J.; WOLFF, G. B. (2006). What Do Deficits Tell Us About Debt? Empirical Evidence on Creative Accounting With Fiscal Rules in the EU, Journal of Banking \& Finance, 30(12), p.3259-3279.

WOOLDRIDGE, J.M. (2012), Introductory Econometrics: A Modern Approach, 5th Ed., South Western Publishers. 


\section{APÊNDICE 1 - DOCUMENTOS UTILIZADAS NA CONSTRUÇÃO DA BASE DE DADOS}

\begin{tabular}{|c|c|}
\hline \multicolumn{2}{|r|}{ Fase de Planejamento Orçamentário: Estimativas no ano t-1 para $o$ ano $t$} \\
\hline PLDO & $\begin{array}{l}\text { Executivo encaminha ao Congresso até } 15 / 04 \text { - traz estimativas também para os anos } \\
\mathrm{t}+1 \text { e } \mathrm{t}+2 \\
\text { - Mensagem Presidencial } \\
\text { - Relatório e Parecer Preliminar do Congresso } \\
\text { - Relatório e Parecer Final do Congresso } \\
\text { - Notas Técnicas e Informativos Conjuntos } \\
\end{array}$ \\
\hline LDO & $\begin{array}{l}\text { Congresso aprova até } 17 / 07 \\
-\quad \text { Anexo de Metas Fiscais: também traz estimativas para os anos } \mathrm{t}+1 \text { e } \mathrm{t}+2 \mathrm{e} \\
\text { avaliações dos anos anteriores: } \mathrm{t}-2 \mathrm{e} \mathrm{t}-3 \text {, além de atualizar as informaços sobre } \\
\mathrm{o} \text { ano t-1. } \\
\text { - Anexo de Riscos Fiscais }\end{array}$ \\
\hline PLOA & $\begin{array}{l}\text { Executivo encaminha ao Congresso até 31/08 } \\
\text { - Mensagem Presidencial } \\
\text { - } \text { Notas Técnicas e Informativos Conjuntos } \\
\text { - Relatório da Receita: revisão de parâmetros e avaliação das estimativas de } \\
\text { - Relatório e Parecer Preliminar do Congresso } \\
\text { - Também atualiza os parâmetros para o ano t-1 }\end{array}$ \\
\hline LOA & $\begin{array}{c}\text { Votação até o encerramento da seção legislativa, porém o prazo não é obrigatório } \\
\text { - } \text { Relatório e Parecer Final do Congresso } \\
\text { - Texto da Lei } \\
\text { - } \\
\text { Anexos de Quadros Orçamentários Consolidados, especialmente, } \\
\text { Demonstrativo do Resultado Primário e Nominal do Governo Central } \\
\end{array}$ \\
\hline
\end{tabular}


APÊNDICE 1 - DOCUMENTOS UTILIZADAS NA CONSTRUÇÃO DA BASE DE DADOS - cont.

\section{Fase de Execução Orçamentária: estimativas no ano t para o próprio ano t}

\begin{tabular}{ll}
\hline \hline $\begin{array}{l}\text { Programação Orçamentária e Cronograma } \\
\text { de Desembolso }\end{array}$ & Até 30 dias após a sanção da LOA \\
\hline $\begin{array}{l}\text { Relatório Bimestral de Avaliação de } \\
\text { Receitas e Despesas Primárias }\end{array}$ & Mês seguinte ao encerramento de cada bimestre
\end{tabular}

- Avaliação do cumprimento metas fiscais, com comparação das receitas e despesas realizadas com as estimativas para o bimestre e para o ano; Atualização dos parâmetros macroeconômicos; Atualização das estimativas de receitas e despesas; Justificativa para contingenciamentos ou ampliação dos limites de empenho e movimentação financeira.

- Mostra como o Executivo vai corrigindo as estimativas ao longo do exercício fiscal.

Relatório Quadrimestral de Avaliação do Cumprimento das Metas Fiscais
- $\quad$ Avaliação do cumprimento da meta fiscal quadrimestral; Apresenta a evolução das programações orçamentárias e financeiras; Compara os valores realizados de receita no quadrimestre e no ano com as metas e com as estimativas, com justificativas para os desvios e comparação das estimativas dos parâmetros macroeconômicos com os valores realizados.

\begin{tabular}{l} 
Relatório Resumido de Execução \\
Orçamentária do Tesouro \\
\hline Relatório do Resultado do Tesouro \\
Nacional
\end{tabular}

- Demonstrativos mensais da execução orçamentária com resultados primário, nominal e justificativas.

- Demonstrativos detalhados dos resultados primário e nominal do Governo Central.

\section{Documentos da Fase de Controle: Ano t+1}

- Relatório e Parecer do TCU sobre as contas apresentadas pelo Executivo 


\section{APÊNDICE 2 - ESTATÍSTICAS DESCRITIVAS}

\begin{tabular}{lrrrrrr}
\hline Variáveis & \multicolumn{1}{c}{ Média } & \multicolumn{1}{c}{ Máximo } & Mínimo & Desvio Padrão & Jarque-Bera & \multicolumn{1}{c}{ Prob. } \\
\hline REC_PREV & 784.5744 & 1447.83 & 309.5 & 346.3967 & 6.505573 & 0.038666 \\
REC_DESV & -1.13293 & 76.13 & -195.27 & 32.26846 & 889.9383 & 0 \\
PIB_PREV & 3.151071 & 7.53 & -3.1 & 2.023071 & 12.51205 & 0.001919 \\
PIB_DESVIO & -0.73536 & 2.32 & -3.32 & 1.342405 & 1.347104 & 0.509894 \\
DESP_PREV & 607.0583 & 1168.12 & 232.1 & 282.231 & 6.362788 & 0.041528 \\
DESP_DESVIO & 0.243095 & 63.06 & -51 & 22.99951 & 4.307113 & 0.116071 \\
CAMBIO_PREV & 2.329524 & 3.5 & 1.61 & 0.541997 & 7.271337 & 0.026366 \\
CAMBIO_DESVIO & -0.02095 & 0.43 & -0.58 & 0.19706 & 1.289999 & 0.524663 \\
D_IPCA_META & 1.295238 & 8.9 & -1.4 & 1.96701 & 66.47735 & 0 \\
DLSP_PREV & 44.28155 & 61.9 & 34 & 8.116952 & 8.186409 & 0.016686 \\
DLSP_DESVIO & -2.39583 & 5.88 & -6.81 & 2.834779 & 31.17212 & 0 \\
IGPDI_PREV & 7.604405 & 26.84 & 1.35 & 5.510181 & 150.0755 & 0 \\
IGPDI_DESVIO & 0.413452 & 7.89 & -6.12 & 2.726303 & 7.773039 & 0.020517 \\
IPCA_PREV & 6.3225 & 15.38 & 3.52 & 2.550251 & 176.3169 & 0 \\
IPCA_DESVIO & 0.643214 & 7.83 & -1.24 & 1.893192 & 217.3542 & 0 \\
SELIC_PREV & 13.31988 & 23.79 & 7.27 & 4.141559 & 11.51285 & 0.003162 \\
SELIC_DESVIO & 0.667262 & 8.4 & -3.65 & 2.226108 & 149.7933 & 0 \\
POLITIC & 229.0595 & 431 & 20 & 104.2038 & 3.98752 & 0.136182 \\
IC & 113.4805 & 186.75 & 59.36 & 24.36507 & 5.373945 & 0.068087 \\
CRB & 280.4852 & 422.17 & 145.613 & 57.4317 & 0.539448 & 0.76359 \\
\hline FONTE. Dados da Pesquisa & & & & & &
\end{tabular}


APÊNDICE 3 - COMPORTAMENTO DAS VARIÁVEIS
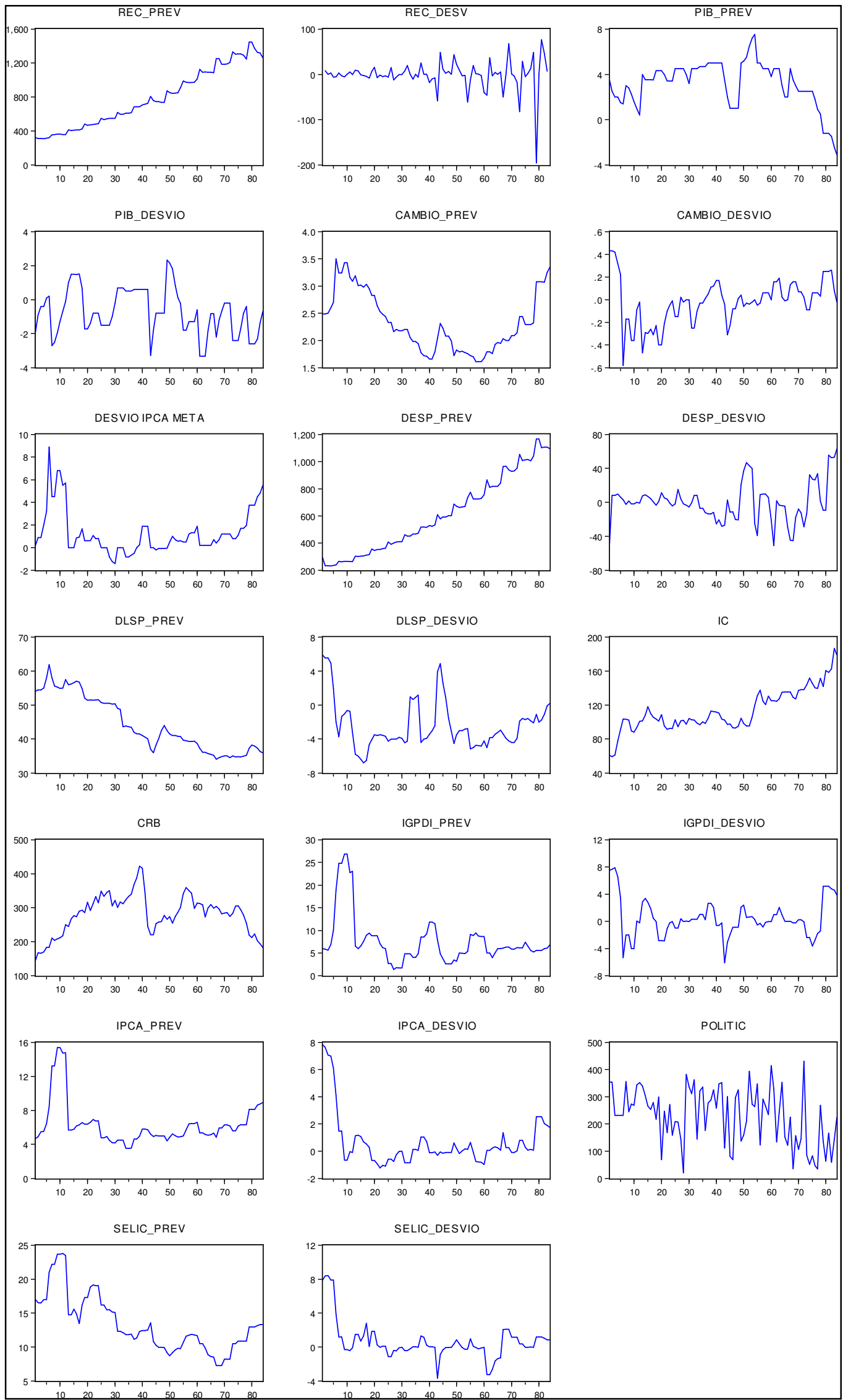

FONTE: Dados da Pesquisa 


\section{APÊNDICE 4 - COMPORTAMENTO DAS VARIÁVEIS EM PRIMEIRA DIFERENÇA}

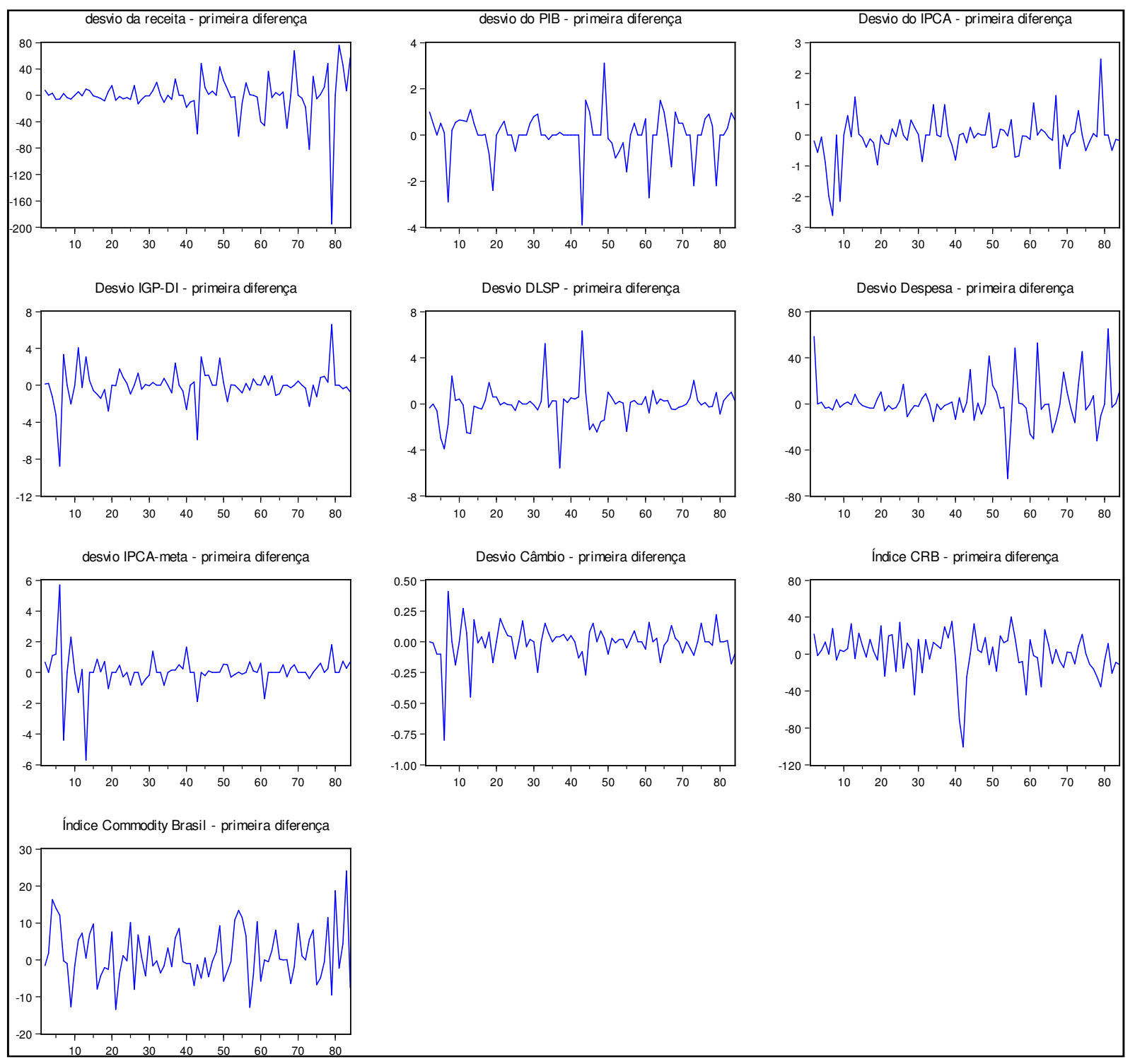

FONTE: Dados da Pesquisa 


\section{APÊNDICE 5 - TESTE AUGMENTED DICKEY-FULLER (ADF) ESCOLHA DO MODELO}

\begin{tabular}{|c|c|c|c|}
\hline Modelo & Estatística- $\tau$ & Defasagem & Decisão \\
\hline \multicolumn{4}{|c|}{ Variável: REC_DESVIO } \\
\hline Const. e tendência & $\begin{array}{l}\widehat{\Phi}_{3}=2.12 \\
\widehat{\Phi}_{2}=1.89 \\
\hat{\tau}_{\beta \tau}=-1,72 \\
\hat{\tau}_{\alpha \tau}=0.97\end{array}$ & 18 & $\begin{array}{l}\text { Não rejeita Ho: } \beta=0 \\
\text { Não rejeita Ho: } \alpha \text { e } \beta=0\end{array}$ \\
\hline Constante & $\begin{array}{l}\hat{\tau}_{\alpha \mu}=-0.97 \\
\Phi_{1}=0.67\end{array}$ & 18 & Não Rejeita Ho: $\alpha=0$ \\
\hline $\begin{array}{l}\text { Sem constante e sem } \\
\text { tendência }\end{array}$ & $\begin{array}{l}\gamma=-0.96 \\
1 \%=-2,60 \\
5 \%=-1,94 \\
10 \%=-1,61\end{array}$ & 19 & $\begin{array}{l}\text { Não rejeita Ho: } 1 \text { raiz unitária } \\
\text { Conclusão: } \mathrm{I}(1)\end{array}$ \\
\hline \multicolumn{4}{|c|}{ Variável: PIB_DESVIO } \\
\hline Const. e tendência & $\begin{array}{l}\widehat{\Phi}_{3}=1.14 \\
\widehat{\Phi}_{2}=1.17 \\
\hat{\tau}_{\beta \tau}=-1.28 \\
\hat{\tau}_{\alpha \tau}=0.68\end{array}$ & 17 & $\begin{array}{l}\text { Não Rejeita Ho: } \beta=0 \\
\text { Não Rejeita Ho: } \alpha \text { e } \beta=0\end{array}$ \\
\hline Constante & $\begin{array}{l}\hat{\tau}_{\alpha \mu}=-0.93 \\
\Phi_{1}=0.60\end{array}$ & 17 & Não Rejeita Ho: $\alpha=0$ \\
\hline $\begin{array}{l}\text { Sem constante e sem } \\
\text { tendência }\end{array}$ & $\gamma=0.8293$ & 17 & $\begin{array}{l}\text { Não rejeita Ho: } 1 \text { raiz unitária } \\
\text { Conclusão: } \mathrm{I}(1)\end{array}$ \\
\hline \multicolumn{4}{|c|}{ Variável: DLSP_DESVIO } \\
\hline Const. e tendência & $\begin{array}{l}\widehat{\Phi}_{3}=0.013 \\
\widehat{\Phi}_{2}=1.65 \\
\hat{\tau}_{\beta \tau}=0.14 \\
\hat{\tau}_{\alpha \tau}=-1.51\end{array}$ & 14 & $\begin{array}{l}\text { Não Rejeita Ho: } \beta=0 \\
\text { Não Rejeita Ho: } \alpha \text { e } \beta=0\end{array}$ \\
\hline Constante & $\begin{array}{l}\hat{\tau}_{\alpha \mu}=-2.55 \\
\Phi_{1}=3.84\end{array}$ & 10 & Não Rejeita Ho: $\alpha=0$ \\
\hline $\begin{array}{l}\text { Sem constante e sem } \\
\text { tendência }\end{array}$ & $\gamma=-1.42$ & 10 & $\begin{array}{l}\text { Não rejeita Ho: } 1 \text { raiz unitária } \\
\text { Conclusão: } \mathrm{I}(1)\end{array}$ \\
\hline \multicolumn{4}{|c|}{ Variável: IPCA_DESVIO } \\
\hline Const. e tendência & $\begin{array}{l}\widehat{\Phi}_{3}=2.39 \\
\widehat{\Phi}_{2}=2.08 \\
\hat{\tau}_{\beta \tau}=1.97 \\
\hat{\tau}_{\alpha \tau}=-1.60\end{array}$ & 12 & $\begin{array}{l}\text { Não Rejeita Ho: } \beta=0 \\
\text { Não Rejeita Ho: } \alpha \text { e } \beta=0\end{array}$ \\
\hline Constante & $\begin{array}{l}\hat{\tau}_{\alpha \mu}=1.07 \\
\Phi_{1}=0.70\end{array}$ & 12 & Não Rejeita Ho: $\alpha=0$ \\
\hline $\begin{array}{l}\text { Sem constante e sem } \\
\text { tendência }\end{array}$ & $\gamma=-0.6$ & 12 & $\begin{array}{l}\text { Não rejeita Ho: } 1 \text { raiz unitária } \\
\text { Conclusão: } \mathrm{I}(1)\end{array}$ \\
\hline \multicolumn{4}{|c|}{ Variável: IGPDI_DESVIO } \\
\hline Const. e tendência & $\begin{array}{l}\widehat{\Phi}_{3}=0.70 \\
\widehat{\Phi}_{2}=0.51 \\
\hat{\tau}_{\beta \tau}=1.95 \\
\hat{\tau}_{\alpha \tau}=-1.87\end{array}$ & 4 & $\begin{array}{l}\text { Não Rejeita Ho: } \beta=0 \\
\text { Não Rejeita Ho: } \alpha \text { e } \beta=0\end{array}$ \\
\hline Constante & $\begin{array}{l}\hat{\tau}_{\alpha \mu}=0.35 \\
\Phi_{1}=0.064\end{array}$ & 4 & Não Rejeita Ho: $\alpha=0$ \\
\hline $\begin{array}{l}\text { Sem constante e sem } \\
\text { tendência }\end{array}$ & $\gamma=-1,30$ & 4 & $\begin{array}{l}\text { Não rejeita Ho: } 1 \text { raiz unitária } \\
\text { Conclusão: I(1) }\end{array}$ \\
\hline
\end{tabular}




\begin{tabular}{|c|c|c|c|}
\hline Const. e tendência & $\begin{array}{l}\widehat{\Phi}_{3}=0.23 \\
\widehat{\Phi}_{2}=0.21 \\
\hat{\tau}_{\beta \tau}=0.62 \\
\hat{\tau}_{\alpha \tau}=-0.71\end{array}$ & 12 & $\begin{array}{l}\text { Não Rejeita Ho: } \beta=0 \\
\text { Não Rejeita Ho: } \alpha \text { e } \beta=0\end{array}$ \\
\hline Constante & $\begin{array}{l}\hat{\tau}_{\alpha \mu}=-0.36 \\
\Phi_{1}=0.08\end{array}$ & 12 & Não Rejeita Ho: $\alpha=0$ \\
\hline $\begin{array}{l}\text { Sem constante e sem } \\
\text { tendência }\end{array}$ & $\gamma=-1.59$ & 12 & $\begin{array}{l}\text { Não rejeita Ho: } 1 \text { raiz unitária } \\
\text { Conclusão: } \mathrm{I}(1)\end{array}$ \\
\hline \multicolumn{4}{|c|}{ Variável: CAMBIO_DESVIO } \\
\hline Const. e tendência & $\begin{array}{l}\widehat{\Phi}_{3}=2.81 \\
\widehat{\Phi}_{2}=0.10 \\
\hat{\tau}_{\beta \tau}=2.36 \\
\hat{\tau}_{\alpha \tau}=-2.47\end{array}$ & 0 & $\begin{array}{l}\text { Não Rejeita Ho: } \beta=0 \\
\text { Não Rejeita Ho: } \alpha \text { e } \beta=0\end{array}$ \\
\hline Constante & $\begin{array}{l}\hat{\tau}_{\alpha \mu}=0.98 \\
\Phi_{1}=0.66\end{array}$ & 17 & Não Rejeita Ho: $\alpha=0$ \\
\hline $\begin{array}{l}\text { Sem constante e sem } \\
\text { tendência }\end{array}$ & $\gamma=-4.06$ & 0 & $\begin{array}{l}\text { Rejeita Ho: } 1 \text { raiz unitária } \\
\text { Conclusão: } \mathrm{I}(0)\end{array}$ \\
\hline \multicolumn{4}{|c|}{ Variável: SELIC_DESVIO } \\
\hline Const. e tendência & $\begin{array}{l}\widehat{\Phi}_{3}=0.014 \\
\widehat{\Phi}_{2}=0.11 \\
\hat{\tau}_{\beta \tau}=-0.16 \\
\hat{\tau}_{\alpha \tau}=0.35\end{array}$ & 6 & $\begin{array}{l}\text { Não Rejeita Ho: } \beta=0 \\
\text { Não Rejeita Ho: } \alpha \text { e } \beta=0\end{array}$ \\
\hline Constante & $\begin{array}{l}\hat{\tau}_{\alpha \mu}=0.52 \\
\Phi_{1}=0.15\end{array}$ & 6 & Não Rejeita Ho: $\alpha=0$ \\
\hline $\begin{array}{l}\text { Sem constante e sem } \\
\text { tendência }\end{array}$ & $\gamma=-1.53$ & 6 & $\begin{array}{l}\text { Não rejeita Ho: } 1 \text { raiz unitária } \\
\text { Conclusão: } \mathrm{I}(1)\end{array}$ \\
\hline \multicolumn{4}{|c|}{ Variável: REC_PREV } \\
\hline Const. e tendência & $\begin{array}{l}\widehat{\Phi}_{3}=2.74 \\
\widehat{\Phi}_{2}=2.15 \\
\hat{\tau}_{\beta \tau}=1.96 \\
\hat{\tau}_{\alpha \tau}=1.63\end{array}$ & 18 & $\begin{array}{l}\text { Não Rejeita Ho: } \beta=0 \\
\text { Não Rejeita Ho: } \alpha \text { e } \beta=0\end{array}$ \\
\hline Constante & $\begin{array}{l}\hat{\tau}_{\alpha \mu}=0.80 \\
\Phi_{1}=00.45\end{array}$ & 18 & Não Rejeita Ho: $\alpha=0$ \\
\hline $\begin{array}{l}\text { Sem constante e sem } \\
\text { tendência }\end{array}$ & $\gamma=-1,64$ & 18 & $\begin{array}{l}\text { Não rejeita Ho: } 1 \text { raiz unitária (5\%) } \\
\text { Conclusão: I(1) }\end{array}$ \\
\hline \multicolumn{4}{|c|}{ Variável: PIB_PREV } \\
\hline Const. e tendência & $\begin{array}{l}\widehat{\Phi}_{3}=22,41 \\
\widehat{\Phi}_{2}=1,62 \\
\hat{\tau}_{\beta \tau}=-1,83 \\
\hat{\tau}_{\alpha \tau}=0,68\end{array}$ & 18 & $\begin{array}{l}\text { Não Rejeita Ho: } \beta=0 \\
\text { Não Rejeita Ho: } \alpha \text { e } \beta=0\end{array}$ \\
\hline Constante & $\begin{array}{l}\hat{\tau}_{\alpha \mu}=-0,16 \\
\Phi_{1}=0,017\end{array}$ & 18 & Não Rejeita Ho: $\alpha=0$ \\
\hline $\begin{array}{l}\text { Sem constante e sem } \\
\text { tendência }\end{array}$ & $\gamma=-1,17$ & 0 & $\begin{array}{l}\text { Não rejeita Ho: } 1 \text { raiz unitária } \\
\text { Conclusão: I(1) }\end{array}$ \\
\hline \multicolumn{4}{|c|}{ Variável: DESP_PREV } \\
\hline Const. e tendência & $\begin{array}{l}\widehat{\Phi}_{3}=4.72 \\
\widehat{\Phi}_{2}=7.52 \\
\hat{\tau}_{\beta \tau}=2.61 \\
\hat{\tau}_{\alpha \tau}=3.80\end{array}$ & 17 & $\begin{array}{l}\text { Não Rejeita Ho: } \beta=0 \\
\text { Não Rejeita Ho: } \alpha \text { e } \beta=0\end{array}$ \\
\hline Constante & $\begin{array}{l}\hat{\tau}_{\alpha \mu}=2.90 \\
\Phi_{1}=5.80\end{array}$ & 17 & $\begin{array}{l}\text { Rejeita Ho: } \alpha=0 \\
\text { Modelo II } \\
\text { Não rejeita Ho: } 1 \text { raiz unitária }\end{array}$ \\
\hline
\end{tabular}




\begin{tabular}{|c|c|c|c|}
\hline & $\gamma=2.62$ & & Conclusão: I(1) \\
\hline \multicolumn{4}{|c|}{ Variável: DLSP_PREV } \\
\hline Const. e tendência & $\begin{array}{l}\widehat{\Phi}_{3}=0.80 \\
\widehat{\Phi}_{2}=1.23 \\
\hat{\tau}_{\beta \tau}=-1.16 \\
\hat{\tau}_{\alpha \tau}=1.38\end{array}$ & 10 & $\begin{array}{l}\text { Não Rejeita Ho: } \beta=0 \\
\text { Não Rejeita Ho: } \alpha \text { e } \beta=0\end{array}$ \\
\hline Constante & $\begin{array}{l}\hat{\tau}_{\alpha \mu}=1.32 \\
\Phi_{1}=1.03\end{array}$ & 10 & Não Rejeita Ho: $\alpha=0$ \\
\hline $\begin{array}{l}\text { Sem constante e sem } \\
\text { tendência }\end{array}$ & $\gamma=-1.50$ & 13 & $\begin{array}{l}\text { Não rejeita Ho: } 1 \text { raiz unitária } \\
\text { Conclusão: } \mathrm{I}(1)\end{array}$ \\
\hline \multicolumn{4}{|c|}{ Variável: IGPDI_PREV } \\
\hline Const. e tendência & $\begin{array}{l}\widehat{\Phi}_{3}=0.008 \\
\widehat{\Phi}_{2}=1.53 \\
\hat{\tau}_{\beta \tau}=-0.12 \\
\hat{\tau}_{\alpha \tau}=1.10\end{array}$ & 7 & $\begin{array}{l}\text { Não Rejeita Ho: } \beta=0 \\
\text { Não Rejeita Ho: } \alpha \text { e } \beta=0\end{array}$ \\
\hline Constante & $\begin{array}{l}\hat{\tau}_{\alpha \mu}=2.04 \\
\Phi_{1}=2.32\end{array}$ & 7 & Não Rejeita Ho: $\alpha=0$ \\
\hline $\begin{array}{l}\text { Sem constante e sem } \\
\text { tendência }\end{array}$ & $\gamma=-1.48$ & 7 & $\begin{array}{l}\text { Não rejeita Ho: } 1 \text { raiz unitária } \\
\text { Conclusão: } \mathrm{I}(1)\end{array}$ \\
\hline \multicolumn{4}{|c|}{ Variável: CAMBIO_PREV } \\
\hline Const. e tendência & $\begin{array}{l}\widehat{\Phi}_{3}=0,75 \\
\widehat{\Phi}_{2}=0,73 \\
\hat{\tau}_{\beta \tau}=1,22 \\
\hat{\tau}_{\alpha \tau}=-0,18\end{array}$ & 0 & $\begin{array}{l}\text { Não Rejeita Ho: } \beta=0 \\
\text { Não Rejeita Ho: } \alpha \text { e } \beta=0\end{array}$ \\
\hline Constante & $\begin{array}{l}\hat{\tau}_{\alpha \mu}=0,82 \\
\Phi_{1}=0,34\end{array}$ & 0 & Não Rejeita Ho: $\alpha=0$ \\
\hline $\begin{array}{l}\text { Sem constante e sem } \\
\text { tendência }\end{array}$ & $\gamma=0,41$ & 0 & $\begin{array}{l}\text { Não rejeita Ho: } 1 \text { raiz unitária } \\
\text { Conclusão: I(1) }\end{array}$ \\
\hline \multicolumn{4}{|c|}{ Variável: IPCA_PREV } \\
\hline Const. e tendência & $\begin{array}{l}\widehat{\Phi}_{3}=3.04 \\
\widehat{\Phi}_{2}=2.38 \\
\hat{\tau}_{\beta \tau}=2.22 \\
\hat{\tau}_{\alpha \tau}=-0.25\end{array}$ & 12 & $\begin{array}{l}\text { Não Rejeita Ho: } \beta=0 \\
\text { Não Rejeita Ho: } \alpha \text { e } \beta=0\end{array}$ \\
\hline Constante & $\begin{array}{l}\hat{\tau}_{\alpha \mu}=0.90 \\
\Phi_{1}=0,50\end{array}$ & 12 & Não Rejeita Ho: $\alpha=0$ \\
\hline $\begin{array}{l}\text { Sem constante e sem } \\
\text { tendência }\end{array}$ & $\gamma=0.70$ & 12 & $\begin{array}{l}\text { Não rejeita Ho: } 1 \text { raiz unitária } \\
\text { Conclusão: } \mathrm{I}(1)\end{array}$ \\
\hline \multicolumn{4}{|c|}{ Variável: SELIC_PREV } \\
\hline Const. e tendência & $\begin{array}{l}\widehat{\Phi}_{3}=2.29 \\
\widehat{\Phi}_{2}=2.75 \\
\hat{\tau}_{\beta \tau}=-2.09 \\
\hat{\tau}_{\alpha \tau}=2.65\end{array}$ & 3 & $\begin{array}{l}\text { Não Rejeita Ho: } \beta=0 \\
\text { Não Rejeita Ho: } \alpha \text { e } \beta=0\end{array}$ \\
\hline Constante & $\begin{array}{l}\hat{\tau}_{\alpha \mu}=1.95 \\
\Phi_{1}=2.08\end{array}$ & 6 & Não Rejeita Ho: $\alpha=0$ \\
\hline $\begin{array}{l}\text { Sem constante e sem } \\
\text { tendência }\end{array}$ & $\gamma=-1.23$ & 5 & $\begin{array}{l}\text { Não rejeita Ho: } 1 \text { raiz unitária } \\
\text { Conclusão: } \mathrm{I}(1)\end{array}$ \\
\hline \multicolumn{4}{|c|}{ Variável: POLITIC } \\
\hline Const. e tendência & $\begin{array}{l}\widehat{\Phi}_{3}=4.71 \\
\widehat{\Phi}_{2}=3.52 \\
\hat{\tau}_{\beta \tau}=-3.05 \\
\hat{\tau}_{\alpha \tau}=6.69\end{array}$ & 0 & $\begin{array}{l}\text { Não Rejeita Ho: } \beta=0 \\
\text { Não Rejeita Ho: } \alpha \text { e } \beta=0\end{array}$ \\
\hline Constante & $\begin{array}{l}\hat{\tau}_{\alpha \mu}=3.01 \\
\Phi_{1}=4.72\end{array}$ & 2 & Não Rejeita Ho: $\alpha=0$ \\
\hline $\begin{array}{l}\text { Sem constante e sem } \\
\text { tendência }\end{array}$ & $\gamma=-1.23$ & 5 & $\begin{array}{l}\text { Não rejeita Ho: } 1 \text { raiz unitária } \\
\text { Conclusão: I(1) }\end{array}$ \\
\hline
\end{tabular}




\begin{tabular}{l|l|c|l}
\hline \multicolumn{3}{|c|}{ Variável: CRB } \\
\hline Const. e tendência & $\begin{array}{l}\widehat{\Phi}_{3}=1,61 \\
\widehat{\Phi}_{2}=2,68 \\
\hat{\tau}_{\beta \tau}=-1,73 \\
\hat{\tau}_{\alpha \tau}=2,31\end{array}$ & 4 & $\begin{array}{l}\text { Não Rejeita Ho: } \beta=0 \\
\text { Não Rejeita Ho: } \alpha \text { e } \beta=0\end{array}$ \\
\hline Constante & $\begin{array}{l}\hat{\tau}_{\alpha \mu}=2,09 \\
\Phi_{1}=2,35\end{array}$ & 4 & Não Rejeita Ho: $\alpha=0$ \\
\hline $\begin{array}{l}\text { Sem constante e sem } \\
\text { tendência }\end{array}$ & $\gamma=-0,26$ & 4 & $\begin{array}{l}\text { Não rejeita Ho: } 1 \text { raiz unitária } \\
\text { Conclusão: I(1) }\end{array}$ \\
\hline \hline
\end{tabular}

Valores Críticos Tabelados por Dickey-Fuller (1981) para 100 observações a 5\%

\begin{tabular}{l|l|l|l|l|l}
\hline$\tau_{\alpha \mu}=2,54$ & $\tau_{\alpha \tau}=3,11$ & $\tau_{\beta \tau}=2,79$ & $\Phi_{1}=4,71$ & $\Phi_{2}=4,88$ & $\Phi_{3}=6,49$ \\
\hline
\end{tabular}

Nota: Valores críticos tabelados modelo 1: $1 \%=-2,59 ; 5 \%=-1,94 ; 10 \%=-1,61$. 